\title{
Analytical Hydrological Modelling of Green Roof Technology on a WATERSHED BASIS
}

\author{
by \\ Andrew Chan, \\ Bachelor of Science (Engineering), University of Guelph, \\ Guelph, Ontario, Canada 2004
}

\begin{abstract}
A Thesis
presented to Ryerson University in partial fulfillment of the requirements for the degree of Master of Applied Science

In the Program of

Environmental Applied Science and Management
\end{abstract}

Toronto, Ontario, Canada, 2009

(c)Andrew Chan 2009 


\section{AUthor's Declaration}

I hereby declare that I am the sole author of this thesis.

I authorize Ryerson University to lend this thesis to other institutions or individuals for the purpose of scholarly research.

I further authorize Ryerson University to reproduce this thesis by photocopying or by other means, in total or in part, at the request of other institution or individuals for the purpose of scholarly research. 


\title{
Analytical Hydrological Modelling of Green Roof Technology on a WATERSHED BASIS
}

\author{
By: Andrew Chan
}

Environmental Applied Science and Management

Master of Applied Science, 2009, Ryerson University, Toronto, Ontario, Canada

\begin{abstract}
Urban stormwater design usually involves a continuous simulation model (CSM). A CSM can determine numerous scenarios and outputs implementing best management practices (BMP). Green roof technology has recently emerged as a BMP. Although a CSM is accurate, an alternative type of model can be used for preliminary planning stages. Based on statistics, analytical modelling does not involve complex computer simulations and is appropriate at planning stages. This applied study calibrated an analytical model using outputs from a CSM created for the Highland Creek watershed in Southern Ontario. The analytical model predicted total runoff volume and runoff volume reduction (from green roof technology) within $0.6-6 \%$ and $4-8 \%$ respectively. Runoff reduction from other research has been found in the range of $1-12 \%$. Analytical tools combined with the Unit Response Function (URF) method can easily be changed for any watershed and highlights the usefulness for predicting runoff on a volumetric basis for watersheds.
\end{abstract}




\section{ACKNOWLEDGEMENTS}

I would like to acknowledge the following parties for their contributions to this thesis.

- Ryerson University

- Toronto and Region Conservation Authority

I would also like to thank my thesis supervisor Dr. James Li for his knowledge, expertise and constant support during the entire process. Dr. Douglas Banting also provided access to resources and expertise employed in this research. 


\section{TABle of Contents}

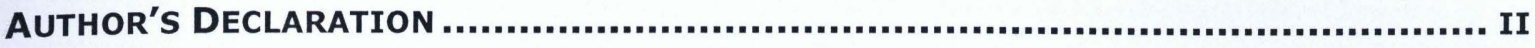

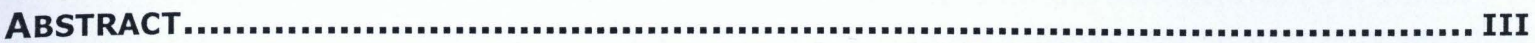

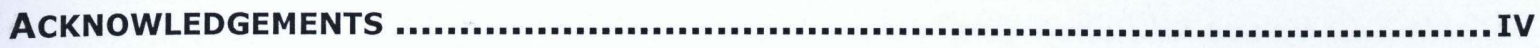

1.0 INTRODUCTION.............................................................................. 1

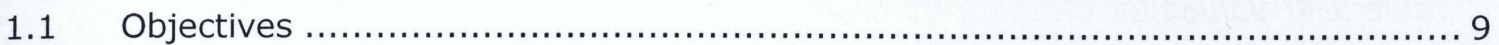

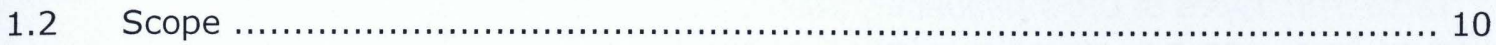

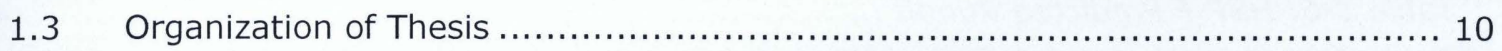

2.0 LITERATURE REVIEW ................................................................. 12

2.1 Storm Water Modelling - Analytical Models ...................................... 12

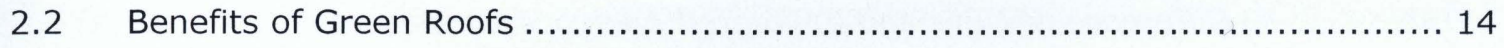

2.2.1 Hydrological Benefits of Green Roofs ....................................... 15

2.3 Hydrological Modelling of Green Roofs......................................... 19

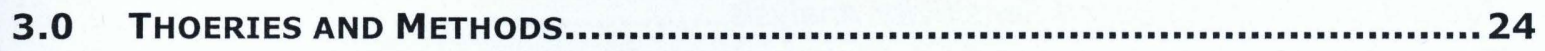

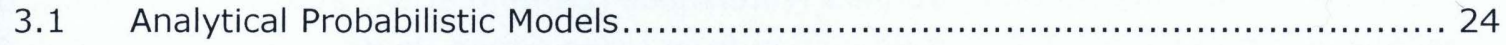

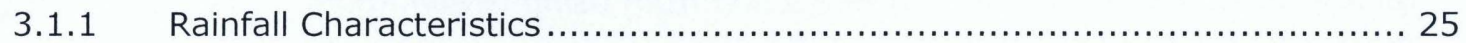

3.1.2 Rainfall-Runoff Transformation ............................................... 27

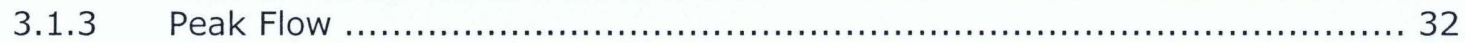

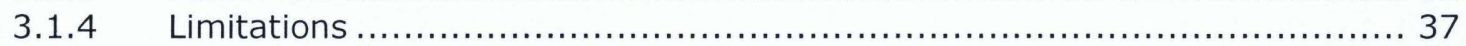

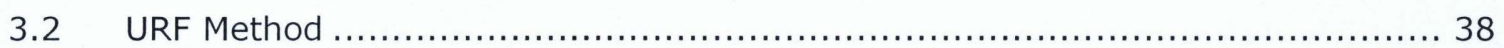

3.3 Calibration of the Analytical Model .............................................. 39

3.3.1 Total Annual Runoff Volume............................................... 44

3.4 Application of Calibrated Analytical URFs ..................................... 45

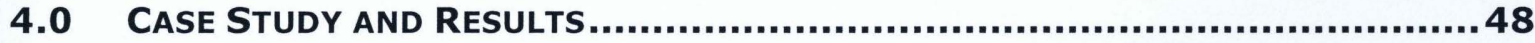

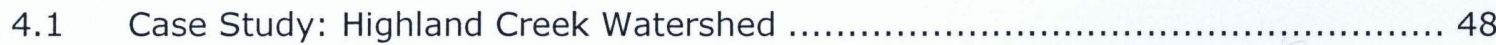

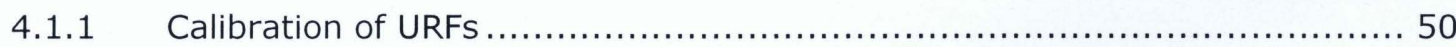

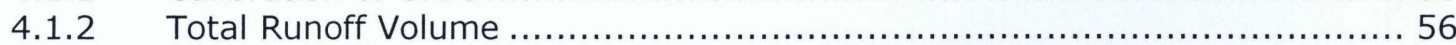

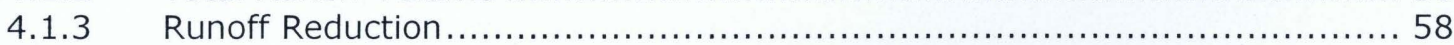

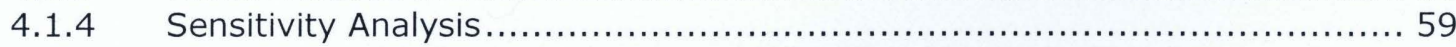

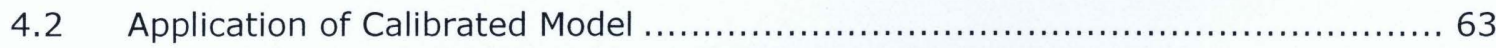

4.3 Peak Flow Analytical Model ...................................................... 66

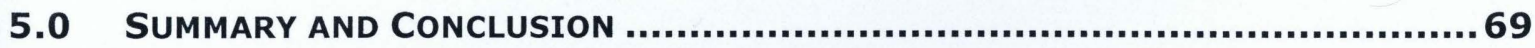

LIST OF REFERENCES ....................................................................... 117

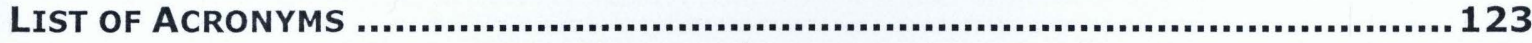




\section{LIST OF TABLES}

Table 1-1: Comparison of CSM and Analytical Models....................................... 5

Table 2-1: Performance Summary of Green Roofs ........................................ 18

Table 3-1: Values for Depression Storage (ASCE, 1992) ..................................... 28

Table 3-2: Values for Runoff Coefficients (Viessman et al., 1996) ........................... 29

Table 3-3: Overland Flow Coefficients for NRCS Velocity Method (Fang et al., 2007).... 34

Table 3-4: Values for Ultimate Infiltration Capacity (Bedient \& Huber, 2008)............... 36

Table 3-5: Types of URFs (Maunder, 2004) ............................................... 41

Table 3-6: HSP-F Predicted Runoff ......................................................... 45

Table 4-1: Statistical Rainfall Parameters for Analytical Modelling (Adams \& Papa, 2000)

................................................................................................. 51

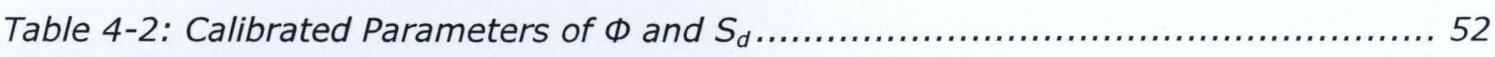

Table 4-3: \% Difference of URFs and Calibrated Analytical Model .......................... 54

Table 4-4: Total Runoff Volume for the Analytical and HSP-F Models ..................... 57

Table 4-5: Runoff Reduction (Analytical and HSP-F Models) .................................. 59

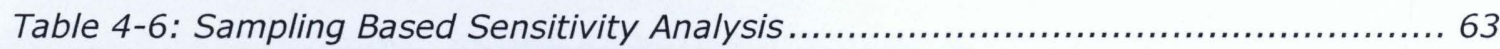

Table 4-7: Runoff Reduction of Various Watersheds (Banting et al., 2005) .................6 64

Table 4-8: Comparison of Runoff Reduction from Using Green Roofs .......................6 65

Table 4-9: Results of Analytical Peak Flow .................................................... 67 


\section{LIST OF FIGURES}

Figure 1-1: Hydrological Cycle (Marsh \& Grossa, 1996) ................................... 1

Figure 1-2: Layers of a Green Roof (Moran et al., 2003).................................. 6

Figure 3-1: Flow Diagram of Applied Study............................................ 24

Figure 3-2: Flow Diagram of Analytical Model (Adams \& Papa, 2000) ....................... 30

Figure 3-3: Transformation of PDF of rainfall volume to PDF of Runoff (Adams \& Papa,

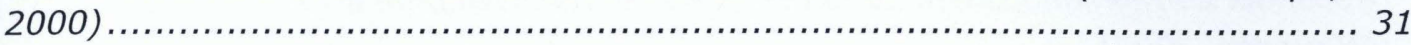

Figure 3-4: URF and Runoff Aggregation Method ...................................... 39

Figure 3-5: URF Development and Calibration........................................ 40

Figure 3-6: Calibration of Analytical URF to HSP-F/URF Data ............................ 43

Figure 4-1: Map of the Highland Creek Watershed (TRCA, 1999) ........................ 49

Figure 4-2: Sensitivity Analysis: Variation of Runoff .................................... 61

Figure 4-3: Sensitivity Analysis: Variation of Depression Storage......................... 62 


\section{LIST OF APPENDICES}

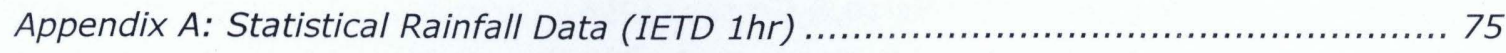

(Adams \& Papa, 2004) ............................................................... 75

Appendix B: URFs Developed for the HSP-F Model .................................. 77

(Maunder, 2004) ........................................................................ 77

Appendix C: Highland Creek Land Use \& Watershed Catchment Plan ...................... 81

(Maunder, 2004) ....................................................................... 81

Appendix D: Calibration and Runoff Tables Using the Analytical Model ..................... 88

Appendix E: Additional Watershed Land Use Data and Runoff Tables ...................... 100

(Banting et al., 2005).................................................................. 100

Appendix F: Highland Creek Sub-catchment Parameters............................... 105

(Aquafor Beech Ltd., 2004) ........................................................... 105

Appendix G: Storm Hydrographs Used for Peak Flow Analysis ...........................109

(Aquafor Beech Ltd., 2004) ........................................................ 109 


\section{Chapter 1}

\subsection{INTRODUCTION}

Urbanization of city centres has drastically modified the movement characteristics of water within city boundaries. This movement of water on a larger scale is known as the hydrologic cycle. The basic components of the hydrological cycle include precipitation, evaporation, evapotranspiration, infiltration, overland flow, stream flow and ground water flow (Bedient \& Huber, 2008). The various components can be spatial and temporally erratic, resulting to extremes that may lead to flooding and drought. Figure 1-1 show the components of the hydrological cycle. Within urban areas, the components of infiltration and overland flow are the most affected. Precipitation is converted to overland flow or runoff and termed 'stormwater' when outlining urban problems. Analysis of the hydrological cycle, specifically in urban systems is necessary for the protection of society and the environment from events such as flooding, erosion and water pollution.

Figure 1-1: Hydrological Cycle (Marsh \& Grossa, 1996)

The liydrologic cycle showing the major exchanges of water among the oceans, the land, and the atmosphere.

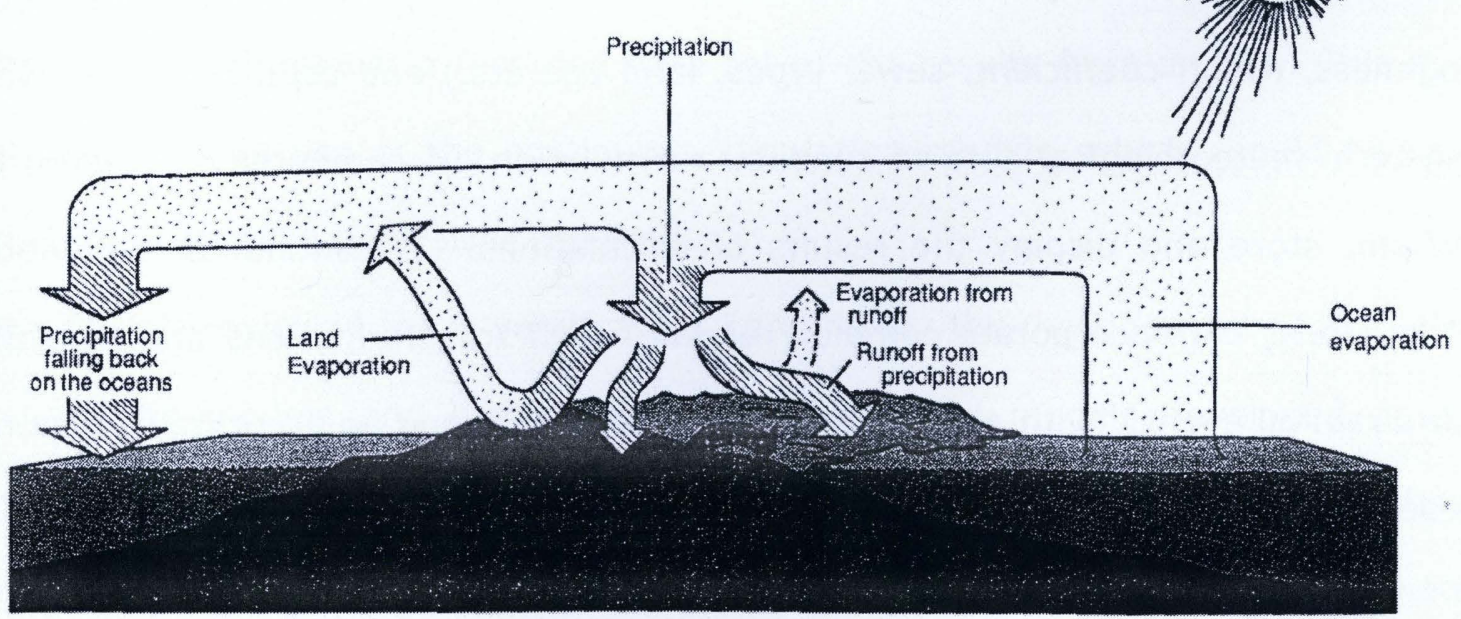


Stormwater conveyance systems were first observed and studied in 1852, when Roe published a table of observations of London sewers (as cited in Adams \& Papa, 2000). Early drainage system design focused on estimating and predicting the peak discharge of an event. The Rational method was one of the earlier adopted methods for calculating peak discharge. Also known as the Lloyd-Davies method in the United Kingdom, the Rational method was the first to include the variable of rainfall frequency in the prediction of peak flow and greatly aided the design of culverts (as cited in ASCE, 1992). However, the rational formula did not provide the 'shape' or the instantaneous volume vs. time during the storm water event (known as a hydrograph). A new unit hydrograph method, advanced by Sherman in 1932 (as cited in Guo, 1998), was proposed to overcome this shortcoming. This method attempts to relate both the peak discharge and the volume of the total runoff to storm characteristics. Additional meteorological, geographical and economic inputs have been factored into the development of other models. To fully characterize the hydrological cycle of a drainage system, designers today use continuous modelling to study its hydrological response under a variety of conditions. This technique uses catchment characteristics (such as slope, channel roughness, runoff coefficient, sewer types, land use etc.) and combines them with long-term meteorological data to conduct a simulation. A computer is required to perform, store and display the results of calculations. A continuous simulation model (CSM) can incorporate complex rainfall-runoff transformations and map the entire rainfall event. With a long history of rainfall data and an accurate simulation model, the results can be accurate to within 5\% (Adams \& Papa, 2000). 
Several stages during urban development do not require the accuracy of a complex analysis tool, such as a CSM. There are different needs from designers and planners at different stages of urban drainage design. During the earlier planning, screening and preliminary phases, limited details are available with which to design a complete system. Although most decision makers want to have solid scientific and mathematical assurances, a continuous model based on assumptions that may change later is not beneficial. Further, continuous simulation modelling can introduce excessive costs and delays to the early design stages, being relatively cumbersome and time consuming due to the data gathering, synthesis and the model creation required. The learning curves for some modelling packages can be steep. The preliminary phases of system design are meant to be relatively short and would benefit from a simpler method or model.

Analytically-derived models and tools can be used as alternatives to continuous simulation modelling. Analytically derived models have evolved such that they offer ease and flexibility while considering long-term meteorology (Smith, 1980). This type of modelling is based on statistics derived from long-term meteorological inputs. Although lacking in detail, these models can be of great use, especially when calibrated against a recorded data set or the results from a CSM. This does not preclude the use of the continuous simulation models, which should be used when more detailed analysis is required.

Papa (1997) reviewed the theoretical background for the development of analytical probabilistic models and highlighted the more useful models developed at the University of Toronto. Adams and Papa (2000) published a reference textbook outlining the development and use of analytical models for storm water 
management planning. Guo (1998) continued this research and further enhanced the analytical models to account for additional parameters such as infiltration (water seepage into the soil) and depression storage (water ponded on natural land surfaces). Since the most important components of the hydrological cycle for urban applications is runoff (overland flow), the analytical methods by Adams and Papa (2000) and Guo (1998) do not provide models for stream flow and ground water flow. A comparison of CSM and analytical models for urban stormwater applications is shown in Table 1-1. The analytical models developed from the researchers at the University of Toronto show promise as planning tools. 
Table 1-1: Comparison of CSM and Analytical Models

\begin{tabular}{|c|c|c|}
\hline & Continuous Simulation Models & Analytical Models \\
\hline $\begin{array}{l}\text { Representation of } \\
\text { Catchment or } \\
\text { Watershed }\end{array}$ & $\begin{array}{c}\text { Simple to complex } \\
\text { Can capture very specific } \\
\text { characteristics }\end{array}$ & $\begin{array}{l}\text { Simple, may not capture } \\
\text { specific characieristics }\end{array}$ \\
\hline Inputs & $\begin{array}{c}\text { Complex, variable } \\
\text { Rainfall, antecedent conditions, } \\
\text { soil conditions, evaporation, } \\
\text { evapotranspiration, depression } \\
\text { storage, reservoir storage, runoff } \\
\text { coefficient, slope, infiltration, } \\
\text { stream/ground water flow }\end{array}$ & $\begin{array}{c}\text { Simple, uniform and/or } \\
\text { area-averaged } \\
\text { Uniform rainfall, } \\
\text { depression storage, runoff } \\
\text { coefficient infiltration }\end{array}$ \\
\hline Outputs & $\begin{array}{l}\text { Single or time series response } \\
\text { Runoff volume, combined sewer } \\
\text { overflow events, water quality }\end{array}$ & $\begin{array}{c}\text { Single event response } \\
\text { Runoff volume, combined } \\
\text { sewer overflow events, } \\
\text { water quality }\end{array}$ \\
\hline Resources & Usually computerized & $\begin{array}{l}\text { Not necessarily } \\
\text { computerized }\end{array}$ \\
\hline Usage & $\begin{array}{l}\text { Detailed design, engineering } \\
\text { Provides specific response } \\
\text { characteristics }\end{array}$ & $\begin{array}{l}\text { Planning, preliminary } \\
\text { Provides average values of } \\
\text { long term performance }\end{array}$ \\
\hline $\begin{array}{l}\text { Water Routing } \\
\text { Mechanics }\end{array}$ & Yes & No \\
\hline Example Models & $\begin{array}{c}\text { HSP-F } \\
\text { Storage, Treatment and Overflow } \\
\text { Runoff Model (STORM) } \\
\text { US EPA Storm Water Management } \\
\text { Model (SWMM) } \\
\text { Quantity-Quantity Simulator } \\
\text { (QQS) }\end{array}$ & $\begin{array}{c}\text { Adams and Papa (2000) } \\
\text { Guo (1998) }\end{array}$ \\
\hline
\end{tabular}

The ultimate purpose of these models is to simulate different scenarios to determine the best outcomes for design problems. Within urban areas, the components of infiltration and overland flow are the most affected. In the case of urban drainage systems, green roof technology was recently identified as a potential control measure to reduce storm water impacts. Green roof technology has been identified as a storm water best management practice (BMP) along with 
other traditional methods (Banting et al., 2005). A green roof is a roof covered with a layer of soil, subsurface matrix and selective vegetation, having various terms such as eco-roof, nature roof or living roof (Perry, 2003). Application of green roof technology is typically only feasible in an urban setting. The sloped and often widely dispersed roofs of rural areas do not make the implementation cost effective. Two main types of green roofs have been illustrated in the literature: intensive and extensive. Intensive green roofs can involve manicured lawns, shrubs, trees, flowers and usually have deeper soil material. They typically require ongoing maintenance and in some cases are expensive and impractical (Perry, 2003). Extensive green roofs include ground cover plants, a thinner soil layer and reduced maintenance costs. Extensive green roofs can be installed on roofs with slopes of up to 40 degrees (Gedge \& Kadas, 2005). Current literature and development focuses on the extensive green roof type (Perry, 2003).

Figure 1-2: Layers of a Green Roof (Moran et al., 2003)

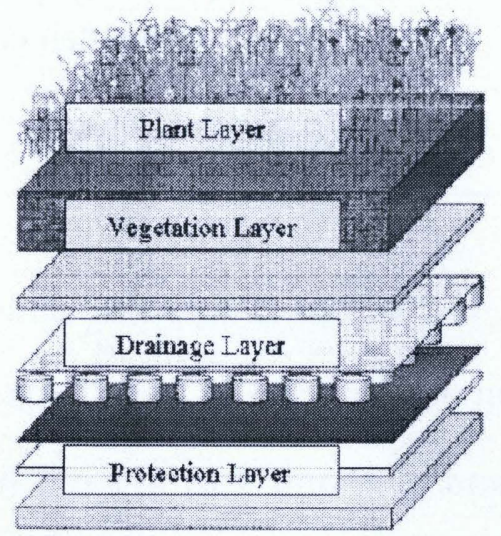

Research and pilot studies have analyzed the hydrological benefits of green roofs (Complete discussion provided in Chapter 2). Studies show that the conversion of a roof space into a pervious area can both reduce the quantity and improve the 
quality of the storm runoff. Liesecke (1998) showed that a green roof with a media depth of $2-4 \mathrm{~cm}$ can retain 40 to $45 \%$ of the annual rainfall. Li (2006) showed that green roofs have the ability to intercept, store and retain moderate and small storm events. Similarly, according to Moran et al. (2003) and Rowe et al. (2003), green roofs can retain up to $100 \%$ of the rainfall volume depending on the volume, intensity and duration. Several of the reviewed studies were performed in Europe, where research and implementation of green roofs is more mature than in North America (Banting et al., 2005).

In 1997, the City of Toronto initiated the development of a Wet Weather Flow Management Master Plan (WWFMMP) (City of Toronto, 2003). The main problem that initiated the plan was the degradation of the City's watersheds and near-shore zone of Lake Ontario. The project goals were to develop a strategy to manage wet weather flow on a watershed basis, to improve the health of Toronto's watercourses, and to enhance the natural environment. The WWFMMP also gave support to the implementation and use of green roof technology (City of Toronto, 2003). In support of this initiative, the Toronto and Region Conservation Authority (TRCA) retained a consultant to develop a "Hydrological Simulation ProgramFortran" (HSP-F) model and a "Unit Response Function" (URF) model in 2004 (Banerjee, 2004). The HSP-F model is a continuous simulation model. The URF model is a simplified model, relating the rainfall to runoff transformation to parcels of land and their corresponding land use. The URF model also incorporates land use types assuming the implementation of green roof technology which was based on the York University green roof monitoring program undertaken by the TRCA in 2003-2004 (TRCA, 2006). The HSP-F and URF models were developed and 
calibrated using meteorological data, based on a hydrological response of a 10 ha test catchment. Eligible green roof area was assumed to be $75 \%$ pervious (green roof) and $25 \%$ impervious (roof). The HSP-F model was calibrated for the Highland Creek and used to estimate the runoff reduction and peak flow reduction of implementing green roof technology (Banerjee, 2004; Maunder, 2004).

Another CSM was created with the Quantity-Quality Simulation (QQS) model used to predict the total annual combined sewer overflow (CSO) of several watersheds in the GTA (Li, 2007). An analytical model, the Sustainable Urban Drainage System (SUDS) model was calibrated to the QQS model to predict CSO events and cost savings (Li, 2007). The number of research studies is still somewhat limited on the overall effect of green roof technology on a watershed basis. Results from these watershed-wide studies have shown that benefits are more modest when compared to individual green roofs. Since predicting the impact of green roof technology on a watershed basis is impractical to study on an experimental or laboratory basis, modelling tools and methods must be used.

An established analytical model to predict the runoff reduction resulting from the implementation of green roof technology on a watershed basis would greatly benefit the planning and preliminary stages of urban stormwater management systems. Currently, the existing green roof projects in North America are isolated, single building efforts within large urban areas. One or two buildings in a watershed will have a small effect. If planners are able to determine the benefits of green roofs under different scenarios, cities, regions and municipalities may be able to enact policies to encourage the use of green roofs. The development of green roofs across an urban centre will have a more dramatic effect. 
The analytical model is simple to use and has the ability to predict annual total runoff volume over an entire watershed. Although such a model still requires data collection per watershed, the calculations are easy to reproduce and based on wellknown methods of statistical analysis. If the results are demonstrated to be reasonable the model could be considered successful. Hydrological models should be calibrated using observed data or post-calibrated data to increase the confidence of the model results ( $\mathrm{Au}, 2007)$. The HSP-F model developed for the Highland Creek watershed provides a solid foundation for calibrating the analytical model presented by Adams \& Papa (2000), thereby creating a simple, powerful tool by which to assess the impact of green roof technology in storm water management on a watershed basis.

\subsection{Objectives}

Important parameters for urban drainage systems are total runoff volume and peak discharge. These parameters can be positively affected using green roof technology, but requires scientific predictions on a watershed basis. Although green roofs have generated increased interest and research, many of the studies have focused on the micro effects of individual green roofs. Some modelling has been performed on the hydrological benefits of green roof technology; however, research has focused on using a CSM to determine the benefits. Using models suitable for planning or preliminary design not been intensively investigated. This applied study has the following goals:

- Develop a watershed modelling approach for green roofs using analytical probabilistic models 
- Calibrate an analytical probabilistic model using the results from a continuous model and obtain reasonable agreement (within 10 to 15\%);

- Estimate the total runoff volume, runoff volume reduction and peak flow reduction within a watershed from the use of green roof technology;

\subsection{Scope}

The objective is a quantitative analysis and model development to predict hydrological benefits of green roof technologies on a watershed basis. Runoff control systems are designed based on the single event total runoff volume, rather than time dependant outputs (Adams \& Papa, 2000). The scope of this research study is:

- To apply the probabilistic analytical model developed by Adams and Papa (2000) and Guo (1998)

- To focus on a specific case study, such as the data and models developed for the Highland Creek watersheds

- To focus on three (3) parameters of interest in a hydrologic system, total runoff volume, peak flow and total runoff volume reduction.

\subsection{Organization of Thesis}

The thesis is comprised of five chapters. Chapter 1 provided an introduction to urban drainage systems, analytical models and green roofs. The research needs, objectives, case studies and scope concluded Chapter 1 . Chapter 2 expands on certain introductory elements, explores current and past research and forms the literature review of the thesis study. The theories and methodologies used to complete the objectives are outlined in Chapter 3. This chapter develops and provides details of the analytical model and explains how model calibration was 
completed. Chapter 4 outlines the Highland Creek case study where the continuous HSP-F model is used to calibrate the analytical model. This chapter is comprised of several sections showing the results of the initial model calibration, sensitivity analysis, use of the calibrated model and the peak flow models. Discussion of the results is also included in Chapter 4 . Chapter 5 concludes the study, providing a summary and recommendations for future research. 


\section{Chapter 2}

\subsection{Literature Review}

The topic of this study is applied and multi disciplinary, combining analytical tools for modelling with new innovative technologies for storm water management and design. As such, this chapter reviews the literature in three main topic areas: analytical hydrological modelling, hydrological benefits of green roofs and hydrological modelling of green roofs.

\subsection{Storm Water Modelling - Analytical Models}

Initially, analytical models were used to determine the performance of storage/treatment systems. Howard (1976) developed the model (as cited in Guo, 1998 ) with rainfall volume and interevent time to analyze the runoff diverted to a storage reservoir. Smith (1980) carried forward the Howard model by solving for the steady-state probability distribution function. The model was taken a step further by modelling a series of catchments in sequence by Schwarz \& Adams (1981) and Adams \& Bontje (1984). Analytical models were well developed.

A comparison between analytical and simulation models was performed by Kauffman (1987). The results showed that favourable agreement existed between the two models. Since the analytical model is dependent on statistical data of rainfall an extensive database for parameters was initially developed and published by Belanger (1992). Validation of the analytical model with continuous simulation models has shown reasonable agreement (within 5-20\%) (Li, 1991; Li \& Adams, 1990; Li \& Adams, 1993; Li \& Adams, 1994; Papa \& Adams, 1997). Chen \& Adams (2005) were able to obtain analytical model results within $3-10 \%$ of results from a continuous simulation model. Adams \& Papa (2000) collected all of the theoretical 
background of the analytical model into a reference book. Their work then developed the analytical probability models and highlighted their applicability to storm water design for prediction of total runoff volume, peak flow, water quality, combined sewer overflow and reservoir capacity. Guo (1998) expanded on the initial work of Adams \& Papa (2000) by further developing the analytical model and incorporated additional parameters such as infiltration into the model. Guo (1998) also provided the development of the analytical model for peak flows, storm water quality control and flood control. Cost-effective urban storm water system design was completed with a screening level analytical model by Li \& Adams (2000) and Chen \& Adams (2004). Analytical model analysis of runoff quality was completed with simple to use spreadsheet tools by Behera et al. (2006). It was found that the long-term runoff quality control assessment could be accurately determined by analytical models.

Analytical models for runoff estimation provide a cost-effective method for analysing the long term performance of urban drainage systems. Analytical models have been validated by a variety of studies and provide good accuracy, in some cases as accurate as continuous simulation models ( $\sim 5-10 \%)$. They are regarded as simple and relatively straight forward to use, with well developed statistical rainfall data basis. Considerable work has been conducted at the University of Toronto; the works by Guo (1998) and Adams \& Papa (2000) forms the main basis of the study. The models to predict total runoff volume and peak flow assume uniform rainfall and cannot capture all of the catchment parameters. The literature review did not cover the development of analytical models for water quality. Guo 
(1998) and Behera et al. (2006) provides additional information concerning the development of models to predict water quality.

\subsection{Benefits of Green Roofs}

Municipalities considering using green roofs as part of any policy require information about their tangible and intangible benefits and costs. Although the green roofing industry in North America is not as mature as in certain places in Europe, considerable resources have been spent on researching the benefits of green roofs on both continents (Banting et al., 2005). With the identification of green roof technology as a BMP, there has been greater interest in their inclusion in urban drainage systems.

Green roof research incorporates a wide array of disciplines including soil and horticultural science, civil and construction engineering, architectural and landscape designing, ecology, urban planning and policy development (Currie, 2005). There are a variety of benefits to the implementation of green roofs, including:

- Energy savings in buildings;

- Reduction of urban heat island effects

- Effects on air quality;

- Effects on health and well-being;

- Reduction of storm water quantities;

- Improvement of storm water quality; and

- Promotion of horticulture and landscaping (Banting et al., 2005).

The additional material placed on the roof of a building typically has good insulating properties. Soil prevents heat transfer during winter and summer, reducing the energy spent on controlling the building climate. Liu \& Baskaran (2003) reported 
field research in Ottawa that green roofs reduced the energy requirement for air conditioning by $75 \%$. The phenomenon of the "urban heat island" where air over urban centres is typically warmer than the surrounding areas, can also be reduced by green roofs. A simulation performed by Bass et al. (2002) showed that green roofs could reduce the urban temperatures by ${ }^{\circ} \mathbb{C}$ and $2^{\circ} \mathrm{C}$ with irrigated green roofs. Using the Urban Forest Effects (UFORE) model, Currie (2005) was able to show a statistically significant air quality increase with city-wide implementation of green roofs. Green roofs help to offset the habitat lost to development (Gedge \& Kadas, 2005). Economic studies have been conducted to evaluate and quantify the costs and savings of implementing green roofs (Banting et al., 2005; Clark et al., 2008; Niachou et al., 2001; Wong et al., 2003). The studies show that all of the benefits provided can produce significant savings for a building. Although not the main focus of this study, green roofs offer a variety of non-hydrological benefits. Many of these benefits have been studied and found to be significant, providing further support for the usefulness of green roofs.

\subsubsection{Hydrological Benefits of Green Roofs}

Since roof areas typically comprise $40-50 \%$ of the impermeable surfaces in urban areas, green roofs can have a large impact on the hydrological response of the drainage system (Dunnett \& Kingsbury, 2008). Unlike some other BMPs, green roofs offer improvements to both the quantity and the quality of storm water runoff. Green roofs are known to retain storm water, delay peak flows and offer filtering effects to improve water quality (Banting et al., 2005). The hydrological benefits of green roof technology have been studied in a variety of locations around 
the world, as shown in the literature reviewed. Storm water management implications of green roofs fall into two main categories: quality and quantity. Johnston \& Newton (1993) showed that plants have the capability to degrade contaminants by direct intake or by binding them with the plant or roots. Their study concluded that over $95 \%$ of cadmium, copper and lead and $16 \%$ of zinc can be removed from storm water runoff with green roof technology. The Toronto and Region Conservation Authority (TRCA) monitoring of storm water performance of a green roof at York University found that loadings of suspended solids, nitrogen complexes, aluminum, copper, biological oxygen demand (BOD), and most polyaromatic hydrocarbons (PAH) were reduced (TRCA, 2006). The green roof at York University in Toronto has an area of approximately $241 \mathrm{~m}^{2}$, covered with grass and wild flowers, and designed to be light-weight. However, higher levels of phosphates, metals, cations and anions were found to be leached from the soil medium than the control green roof. Studies in North Carolina by Moran et al. (2003) found the same leaching trend with increased loadings of nitrogen. The study concluded that careful selection of the soil medium should help ensure that naturally occurring compounds are not leached. Due to the soil matrix, plant and organism relationships, green roofs act as a filter and can improve the water quality.

Over the same monitoring season at York University, total runoff volume was reduced by $55 \%$ and peak flow rates up to $85 \%$ for storm events $<10 \mathrm{~mm}$ (TRCA, 2005). Long rain events were found to saturate the green roof decreasing the storage capability and runoff retention. Results were also affected by the season, with warmer weather showing improved storm water reduction. Two green roofs 
were constructed for field studies in North Carolina, 27 and $70 \mathrm{~m}^{2}$ in size. Approximately $32-100 \%$ of the total rainfall was retained in those constructed green roof (Moran et al., 2003; Moran et al., 2004). Similar to the results obtained at York University, the study found that storm water retention greatly decreased when there was not sufficient time between rain events for the green roof to dry. Storm runoff reduction was decreased by $32-75 \%$ during consecutive rain events. This indicated that the green roof was partly saturated, thereby reducing its remaining capacity. The effectiveness of green roofs for water detention was found to be highly dependent on the volume and intensity of rainfall.

In Sweden, field studies on a small scale green roof with an area of approximately $2 \mathrm{~m}^{2}$ found that $39-62 \%$ of the rainfall was retained (Bengtsson et al., 2005) and that retention diminishes as the slope of the green roof increases (Bengtsson et al., 2005; Nicholaus et al., 2005). In Portland, Oregon (Hutchinson et al., 2003), two green roofs were established. The results over the 15 month period showed that water retention ranged from 59-92\% and favoured warmer weather (Hutchinson et al., 2003). Another American study showed that stress on municipal sewer systems can be reduced by green roofs and 70 to $90 \%$ of the runoff diverted (Perry, 2003). Experiments at the National Research Council, in Canada, showed that a green roof could delay runoff by up to 1.5 hours and reduce runoff volume by $85 \%$ (Liu, 2004). In Rio de Janeiro, Kohler et al. (2002) found that an installed green roof was able to evaporate $60-79 \%$ of the annual precipitation diverting the water from the sewer systems. Green roofs have therefore been shown to have good storm water retention and runoff reduction potential. 
Effects on the peak flow were also considered in several studies. The peak flow of the green roof at York University was delayed by $4 \%$ to $88 \%$ (control roof as $0 \%$ ) (TRCA, 2006). The magnitude of peak flow was also reduced by $46-85 \%$. In North Carolina, a green roof delayed peak runoff up to 2 hours and reduced peak flow by $90 \%$ (Moran et al., 2003; Moran et al., 2004). Table 2-1 summarizes the findings of research studies on the hydrological performance of green roofs.

\section{Table 2-1: Performance Summary of Green Roofs}

\begin{tabular}{|c|c|c|}
\hline Source & Total Runoff Volume Reduction & Peak Flow Reduction \\
\hline Bengtsson et al. 2005 & $39-62 \%$ & Not performed \\
\hline Hutchinson et al. 2003 & $59-92 \%$ & Not performed \\
\hline Kohler et al. 2002 & $60-79 \%$ & Not performed \\
\hline Liu, 2004 & $85 \%$ & Not performed \\
\hline Moran et al. 2003 & $32-100 \%$ & $90 \%$ \\
\hline Moran et al. 2004 & $32-75 \%$ Sequential rainfall events & Not performed \\
\hline Perry, 2003 & $70-90 \%$ & $46-85 \%$ \\
\hline TRCA, 2005 & $55 \%$ & \\
\hline
\end{tabular}

The existing literature and studies conducted on green roofs show that they significantly retain and reduce storm water while delaying the time to peak flow. The effectiveness of green roofs has been shown to diminish with longer and consecutive rain events as might be expected. Green roofs also show better results in warmer weather, due to increased evapotranspiration and looser soil density. Most of the studies were conducted at the bench and pilot scale levels and did not consider the entire watershed and downstream dynamics. The next section examines studies that have considered modelling the hydrological response of single green roofs along with consideration for an entire watershed. 


\subsection{Hydrological Modelling of Green Roofs}

The current literature has focused on evaluating the hydrological reaction of single green roofs to rain events. Little research has been conducted on how to predict the implementation of green roofs on a watershed basis. City and municipal planners want to know how much storm water can be reduced to determine the benefits from smaller sized storm water infrastructure such as pipes, ponds and outfalls. Combined sewer overflows are also a major problem for some cities and reducing the magnitude and frequency of combined sewer overflow (CSO) events can greatly reduce environmental impacts.

Research in this area is based on predicting the expected runoff and peak flow reduction using a variety of techniques. At Lund University, in Sweden, a Sedum album green roof was placed in a parking area. The plot area was monitored and a variety of synthetic rain events were applied over the plot area. Once completed, the researchers fitted a unit hydrograph (time vs. runoff flow plot) and made comparisons with observed data. The average unit hydrograph, from uniform rainfall intensities can accurately simulate the green roof response for any slope and rain event (Bengtsson et al., 2005). This unit hydrograph can be used to model the storm water outflow from a green roof.

Using the data from the York University green roof, Banerjee (2004) developed HSP-F's Unit Response Functions (URF). The URFs describe how certain land use types with and without green roof technology reacts to rain events and how much runoff occurs. The original HSP-F model was first calibrated to meteorological data. Non-green roof URFs were developed representing the control roof at York University. The actual garden roof was used to develop the URFs representing green roof technology. The URF model was calibrated by using the HSP-F model to 
predict actual outflows from the control and roof garden. Good agreement of runoff was obtained (within 0-9\%) for specific storm events. Results were noted to be inconsistent during winter months. Using the calibrated URFs, from Banerjee (2004), Mauder (2004) simulated the results of implementing green roof technology within the Markham Branch of the Highland Creek watershed. Results showed a $3-4 \%$ reduction in total runoff volume. Peak flow was also reduced by $6-$ $20 \%$. Taking this a step further, Banting et al. (2005) extracted the the HSP-F created URFs and directly applied them to the various land uses of all the watersheds in the GTA. Potential runoff reductions ranged from $4 \%$ to $12 \%$ and specific results are provided in Section 4.2 (Banting et al., 2005). Their method provided quick results without the use and time resources needed for a full continuous simulation model.

Li (2007) estimated the reduction of CSO storage volume and the cost savings of implementing green roofs in the City of Toronto. Using the same URF method as Banting et al. (2005), and using analytical models from Adams \& Papa (2000), Li was able to estimate the annual CSO volume. The analytical model, by Li (2007), was calibrated to an existing continuous simulation model (QQS) under a base scenario and then used to estimate the reduction in storage volume for CSO events. Unit cost savings of implementing green roofs are estimated to range from $\$ 570$ to $\$ 15,580$ per hectare of green roof for the City of Toronto ( $\mathrm{Li}, 2007)$. This translates to approximately $\$ 2.8$ to $\$ 78$ million in BMPs infrastructure in Toronto ( $L i, 2007$ ). The study concluded that using the analytical method is suitable for annual runoff volume calculations and reduces the resources needed to run the City of Toronto continuous simulation model, which requires a long time to develop. 
The Green Build-out Model (Casey Trees \& Limno Tech, 2007) was developed to quantify all of the storm water benefits of trees and green roofs. It is based on the land use areas of the District of Columbia in the US State of Washington and the Mike Urban model (Casey Trees \& Limno Tech, 2007). Using a pre-calibrated continuous simulation model, developed for the District during an earlier project, green roofs and trees were added to the model and scenarios were re-analyzed. The model assumed that only $75 \%$ of the roof area could be covered with a green roof and that green roofs can be applied to $90 \%$ of all buildings over 465 square metres. Implementation of green roofs in Washington State was predicted to reduce combined sewer flows by $16.6 \%$ to $24.8 \%$ in various watersheds (Casey Trees \& Limno Tech, 2007). The Green Build-out Model found that their intensive green roof scenario prevented $10 \%$ of total annual stormwater from entering the system (Casey Trees \& Limno Tech, 2007). During the research it was found that the model was complex and time-consuming to set up and run the various scenarios. A "Mini-model" was developed for planning purposes and was not intended to replace the Green Build-out Model. Unit-area reduction factors (UARF) were developed from the Mini-model based on a 100-acre sewershed. The Minimodel found that green roofs can reduce the storm water quantity by 3,685 cubic meters per year per hectare.

The methodology used by Banerjee (2004), Li (2007) and Casey Trees \& Limno Tech (2007) have several differences and similarities. The work by Banerjee (2004) used real time monitoring data from an actual green roof to provide calibration data for a CSM. In comparison, Li (2007) and Casey Trees \& Limno Tech (2007) did not use measurements from a green roof, but instead changed 
watershed parameters based on the assumptions of installing green roofs. Once parameters had been changed, their CSMs were re-run. Out of the three studies only Li (2007) used an analytical model, developed by Adams \& Papa (2000), calibrated to a CSM. Casey Trees \& Limno Tech's (2007) method to develop the UARFs is similar to the development of the URFs by Banerjee (2004) and can be used quickly during the planning of future green roof installations. Li (2007) also concluded that the calibrated analytical model for CSO events is accurate enough for planning purposes.

The literature shows that storm water management benefits are achievable on a watershed basis, although the effect is not as dramatic as with individual green roof studies. Strategies and research should focus on the entire sewershed/watershed to yield the greatest results, since planners are most concerned with implementing green roofs on a watershed basis. Although there are a few studies that determine how the benefits are calculated, there has not been an established method for determining the benefits. It is impractical to perform an experiment over an entire watershed. The most reliable tool currently being employed is the modification of continuous simulation models with green roof attributes to predict the watershed results. Continuous simulation modelling has been described as time consuming and data intensive. The level of detail and accuracy provided by this method may not be warranted during the initial planning stages. Analytical tools have been used and validated to determine storm water runoff (Li, 1991; Li \& Adams, 1990; Li \& Adams, 1993; Li \& Adams, 1994; Papa et al., 1997) and reduction of CSO events ( $\mathrm{Li}, 2007)$ from green roofs on small catchments and areas. Research and results on analytical models to determine the runoff volume reduction of large catchments 
and watersheds is limited. This study provides research into the overall watershed effect of green roofs. 


\section{Chapter 3}

\subsection{Theories ANd Methods}

Figure $3-1$ is a graphical representation of the methodology and data sources for the applied research study. The main steps taken are in bold and data sources identified on the left.

\section{Figure 3-1: Flow Diagram of Applied Study}

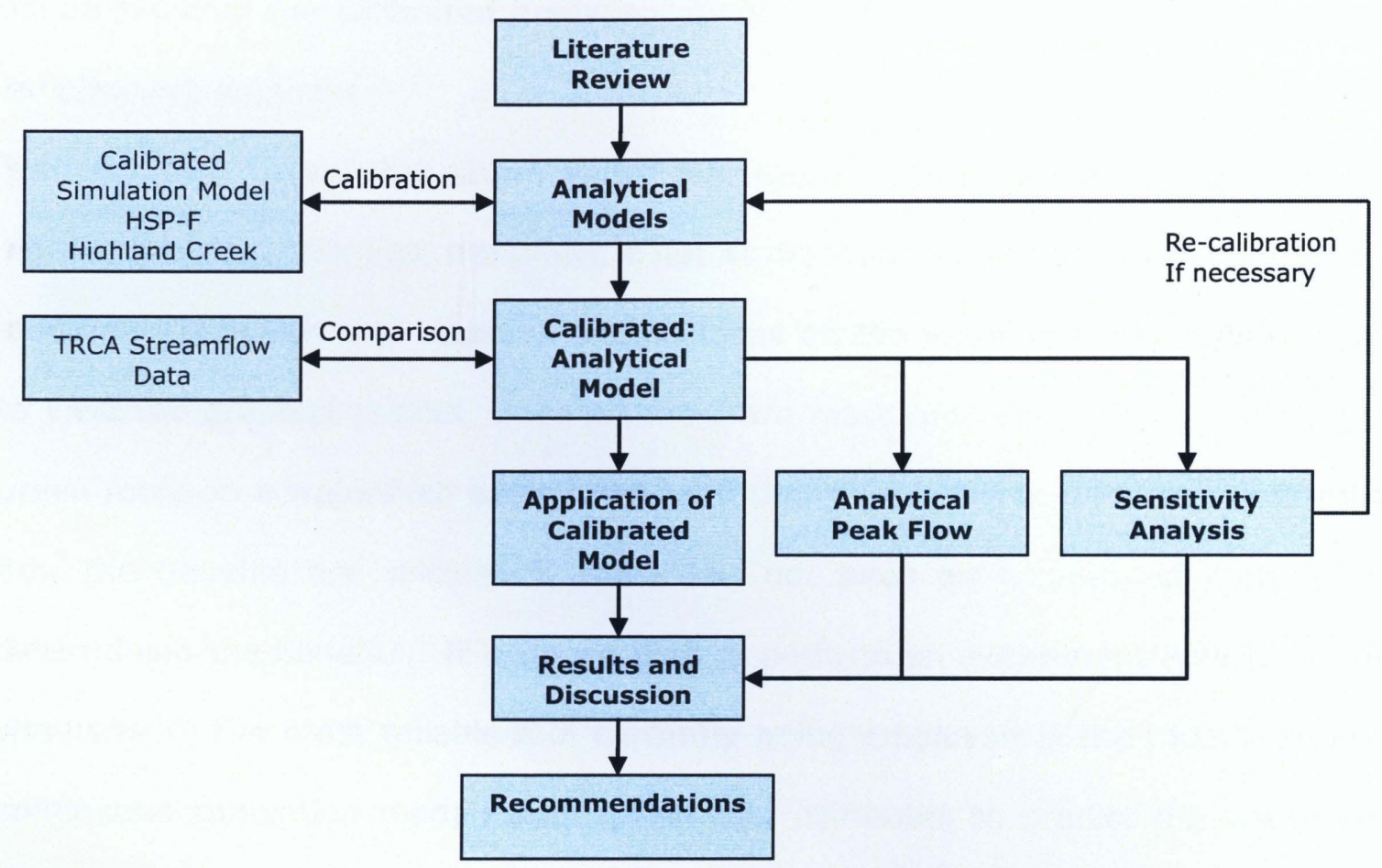

\subsection{Analytical Probabilistic Models}

The development of analytical probabilistic models began with the need to directly solve problems involving urban drainage systems. The probabilistic model involves the statistical analysis of long-term rainfall records. With a long-term record a probability distribution function (pdf) can be developed (Adams \& Papa, 2000). This probability distribution function represents each of the possible rainfall events as a statistical value. For example, with a pdf developed for a certain area, the 
percentage that a rainfall event exceeds $10 \mathrm{~mm}$ or any other amount can be determined. Secondly, a mathematical representation of the rainfall-runoff transformation is developed and with the pdf of rainfall events, the corresponding pdfs of runoff characteristics are found. The process of derivation is based on probability distribution theory, which relates the probability distribution of a dependant random variable to those of the independent variable. The relationship of the independent and dependant variables are expressions of the catchment characteristics and their responses to rainfall. A brief explanation of the corresponding runoff model development is provided; however, it is not the intention of this study to explain in detail the development of probability distribution theory and corresponding analytical models. A more detailed description and derivation of analytical models is outlined by Guo (1998) and Adams \& Papa (2000).

\subsubsection{Rainfall Characteristics}

The main input of the analytical probabilistic model is collected rainfall data. This data needs to be manipulated before being used. A distinction needs to be made between meteorological and statistical events. Actual meteorological events include many characteristics that make them almost impossible to be discretely categorized. However, with enough long-term data, certain characteristics such as rainfall event volume $(v)$, duration $(t)$, and average intensity (i) may be approximated as statistically random variables.

Statistical analysis of rainfall data is started by dividing the continuous data into discrete rainfall events (Adams \& Papa, 2000). A criterion for establishing discrete rainfall events is to determine a minimum time period without rainfall, or interevent 
time definition (IETD). Periods of rainfall separated by a time interval longer than the IETD are considered as separate events. Once events have been discretely separated, the characteristics of these events can be statistically analyzed. Selection of the IETD is based on the intended application. Guo's (1998) recommendation is to ensure that the IETD is greater than the catchment response time and an IETD of 6 hours is appropriate for urban applications. IETDs between 1 and 6 hours had also been suggested for most urban applications by Adams et al. (1986). Once the rainfall events have been separated, the volume, duration and average intensity values can be calculated for every individual rainfall event and analyzed statistically as a sample. Parameters for different IETD values are presented in Appendix A. Selection of an appropriate IETD period and location for the case study is discussed in Chapter 4.

Approximate representation of the pdf of volume, duration and average intensity values is required because real world data does not perfectly match known theoretical probability density functions. Frequency analysis can be performed on the magnitude of such parameters from their histograms and fit to a continuous pdf to the histograms of the rainfall events. There are several types of pdfs, however work by others (Adams \& Papa, 2000; Guo, 1998) has selected an exponential pdf, which using the mathematical constant ' $e$ ', as a reasonable match due to the long records of rainfall data that are usually available. The rainfall characteristics of volume, duration and intensity are expressed as exponential pdfs as outlined in Equations 1-3:

$$
\text { Volume, } v(m m): f(v)=\zeta e^{-\zeta v}
$$




$$
\text { Duration, } t(\mathrm{~h}): f(t)=\lambda e^{-\lambda \mathrm{t}}
$$

$$
\text { Average intensity, } i(\mathrm{~mm} / \mathrm{hr}): f(\mathrm{i})=\beta e^{-\beta i}
$$

where $\zeta\left(\mathrm{mm}^{-1}\right)$ is the inverse of the average rainfall per event parameter, $\overline{\mathrm{v}} ; \lambda(\mathrm{hr}$ $\left.{ }^{1}\right)$ is the inverse of the average duration of rainfall parameter $\bar{t}_{\text {avg }} ;(\mathrm{hr} / \mathrm{mm})$ is the inverse of the average rainfall intensity parameter. $\bar{v}, \zeta, \lambda$ and $\beta$ have been derived for various locations and IETDs, based on long term rainfall data. A compilation of this data is included in Appendix A for IETD $=1 \mathrm{hr}$. These equations are used as the basis for subsequent model development when discussing the probability of the occurrence of a value taken by a random variable. To obtain a probability, an interval must be selected and an integration of the pdf must be performed. For example, to determine the probability of rainfall volume that is less than $10 \mathrm{~mm}$, the integration is performed as follows using Equation 4:

$$
\operatorname{Prob}[0<v<10]=\int_{0}^{10} \zeta e^{-\zeta v}
$$

Note that the pdfs outlined in Equations 1, 2 and 3 have a range from 0 to infinity.

\subsubsection{Rainfall-Runoff Transformation}

Mathematical models of physical processes are used to predict outcomes or values of random variables, such as runoff (Adams \& Papa, 2000). The runoff is directly related to the corresponding rainfall event and can be determined using a rainfallrunoff transformation such as the U.S. Army Corps of Engineers' Storage, Treatment, Overflow, Runoff Model (STORM) (Adams \& Papa, 2000).

$$
v_{r}=\phi\left(v-S_{d}\right)
$$


Where $v_{r}$ is the runoff volume $(\mathrm{mm}), v$ the rainfall volume $(\mathrm{mm}), \Phi$ the runoff coefficient (dimensionless proportionality), and $S_{d}$ the depression storage $(\mathrm{mm})$. The rainfall event volume is typically an input and is provided by the long-term data set. Depression storage refers to the water that accumulates in surface depressions and on foliage during a storm (ASCE, 1992). This water is assumed to eventually evaporate following the storm. Although $S_{d}$ is recognized to be a function of past rainfall, snowmelt and evaporation (ASCE, 1992), for simplicity it is treated as a spatially and temporally averaged constant based on the land use of the catchment. The model assumes that the full value of depression storage is available at the beginning of every rain event. Typical depths of depression storage are provided by ASCE (1992).

Table 3-1: Values for Depression Storage (ASCE, 1992)

\begin{tabular}{|c|c|c|}
\hline Land Type & $\begin{array}{c}\text { Depression Storage } \\
\text { (inches) }\end{array}$ & $\begin{array}{c}\text { Depression Storage } \\
(\mathbf{m m})\end{array}$ \\
\hline Impervious surfaces & $0.05-0.1$ & $1.25-2.5$ \\
\hline Lawns & $0.1-0.2$ & $2.5-5$ \\
\hline Pasture & 0.2 & 5 \\
\hline Forest & 0.3 & 7.5 \\
\hline
\end{tabular}

The runoff coefficient is a dimensionless value, which represents a ratio of runoff volume to effective rainfall volume. It accounts for the integrated effects of rainfall interception, infiltration and other abstractions (ASCE, 1992). The runoff coefficient is usually assumed to be spatially and temporally averaged over the entire rainfall event. Considerable variation exists in this parameter. A table of typical runoff coefficients, by Viessman et al. (1996), is shown in Table 3-2. 
Table 3-2: Values for Runoff Coefficients (Viessman et al., 1996)

\begin{tabular}{|c|c|c|}
\hline Land Use & Area & Runoff Coefficient \\
\hline \multirow{2}{*}{ Business } & Downtown & $0.70-0.95$ \\
\hline & Neighbourhood & $0.50-0.70$ \\
\hline \multirow[t]{5}{*}{ Residential } & Single Family & $0.3-0.5$ \\
\hline & Multi units, detached & $0.4-0.6$ \\
\hline & Multi units, attached & $0.6-0.75$ \\
\hline & Suburban & $0.25-0.4$ \\
\hline & Apartment dwelling & $0.5-0.7$ \\
\hline \multirow[t]{6}{*}{ Industrial } & Light areas & $0.5-0.8$ \\
\hline & Heavy areas & $0.6-0.9$ \\
\hline & Parks, cemeteries & $0.1-0.25$ \\
\hline & Playgrounds & $0.2-0.35$ \\
\hline & Railroad yard areas & $0.2-0.4$ \\
\hline & Unimproved areas & $0.1-0.3$ \\
\hline \multirow[t]{5}{*}{ Streets } & Asphalt & $0.7-0.95$ \\
\hline & Concrete & $0.8-0.95$ \\
\hline & Brick & $0.7-0.85$ \\
\hline & Drives and walks & $0.75-0.85$ \\
\hline & Roofs & $0.75-0.95$ \\
\hline \multirow[t]{3}{*}{ Lawns, sandy soil } & Flat, $2 \%$ & $0.05-0.1$ \\
\hline & Average, $2-7 \%$ & $0.1-0.15$ \\
\hline & Steep, 7\% & $0.15-0.2$ \\
\hline \multirow[t]{3}{*}{ Lawns, heavy soil } & Flat, $2 \%$ & $0.13-0.17$ \\
\hline & Average, $2-7 \%$ & $0.18-0.22$ \\
\hline & Steep, 7\% & $0.25-0.35$ \\
\hline
\end{tabular}

Equation 5 is the fundamental basis for the development of the probabilistic analytical model. It is assumed that $\Phi$ and $S_{d}$ can be determined for a given catchment and that $v$ is a statistically random variable, thereby making $v_{r}$ a random variable. Using the meteorological inputs developed earlier as pdfs, the catchment 
can transform the rainfall volume to runoff volume according to the following relationship, developed by the STORM model:

$$
v_{r}=\left\{\begin{array} { c } 
{ 0 } \\
{ \phi ( \mathrm { v } - S _ { \mathrm { d } } ) }
\end{array} \quad \left\{\begin{array}{l}
v \leq S_{d} \\
v \geq S_{d}
\end{array}\right.\right.
$$

The system of equations states that the rainfall must exceed the depression storage before any runoff occurs. The runoff is generated as a square hydrograph that is transformed into runoff instantaneously without change in shape. This assumption is adequate because designers are more interested in the total runoff volume rather than the exact shape of the runoff hydrograph (Adams \& Papa, 2000). A flow diagram of the analytical model is shown in Figure 3-2 and the rainfall-runoff transformation shown in Figure 3-3.

Figure 3-2: Flow Diagram of Analytical Model (Adams \& Papa, 2000) Rainfall $(\mathrm{v}, \mathrm{t}, \mathrm{i}, \mathrm{b})$

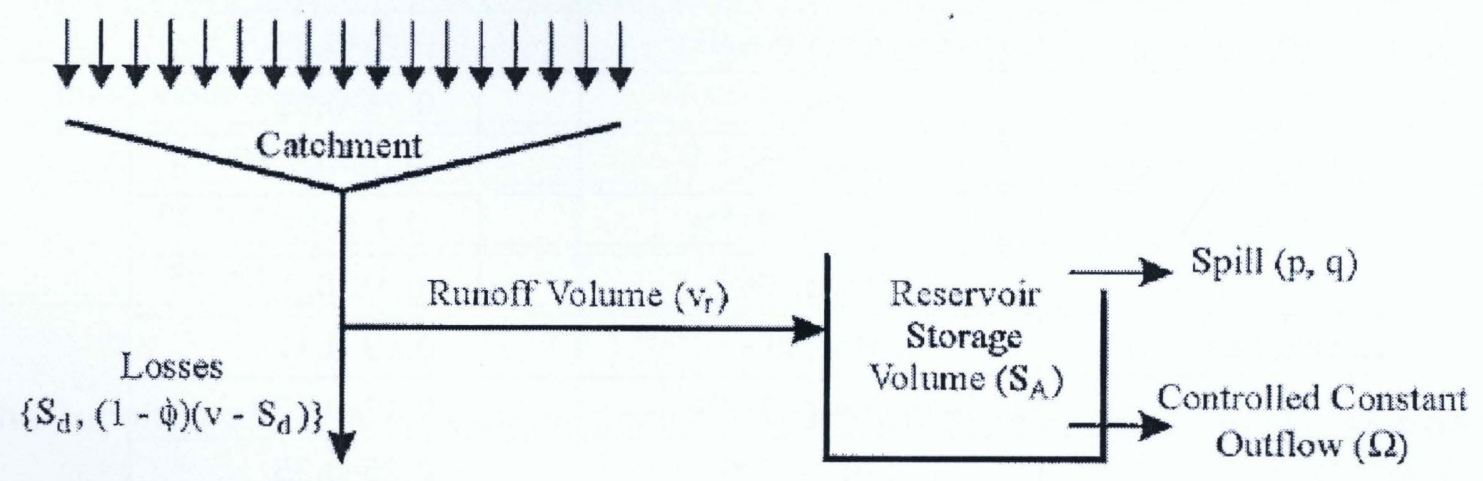


Figure 3-3: Transformation of PDF of rainfall volume to PDF of Runoff (Adams \& Papa, 2000)

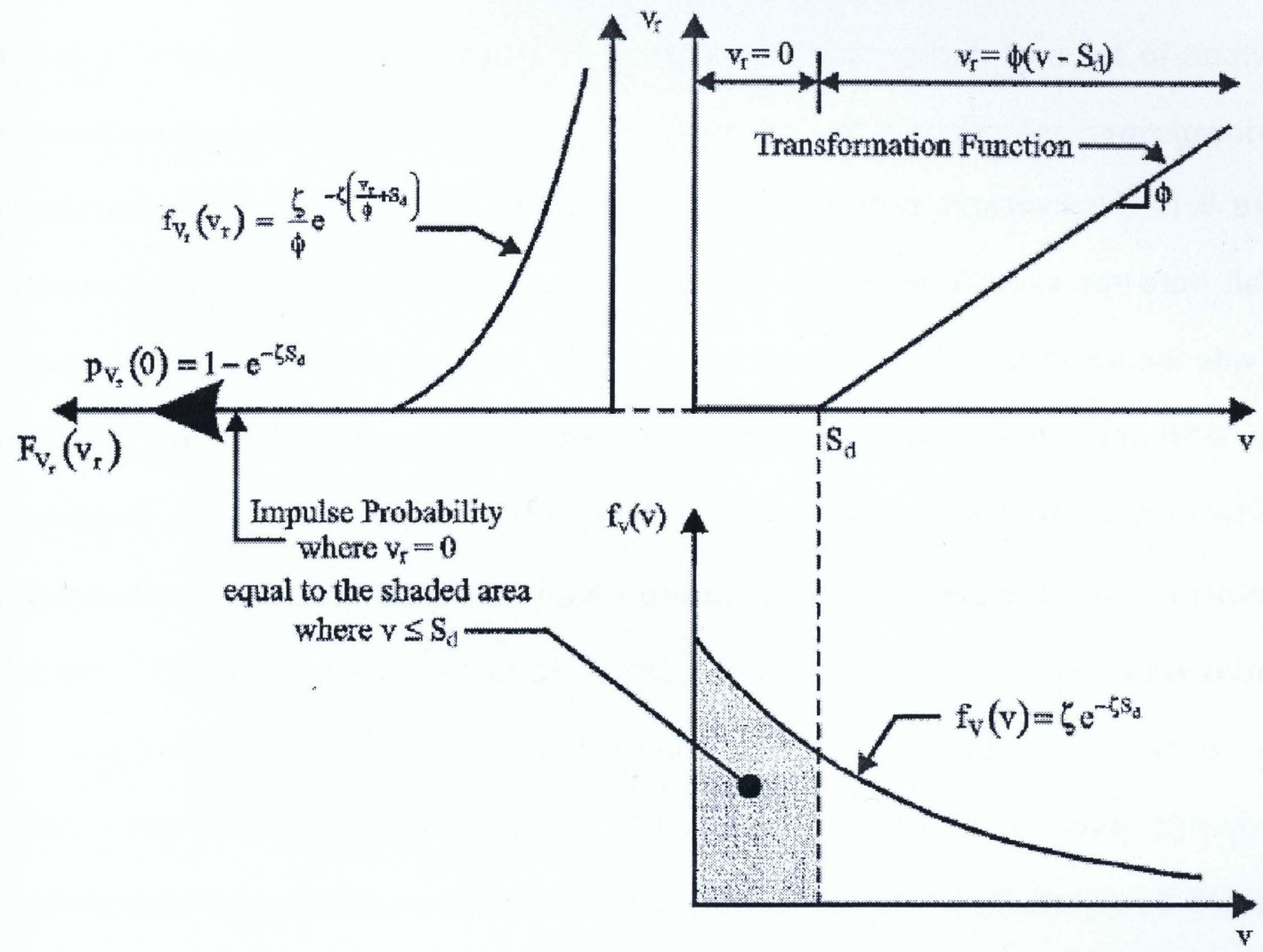

With the previous pdfs developed (Equations $1,2 \& 3$ ) the cumulative distribution function and pdf of runoff volume may be obtained using derived probability distribution theory. The exact details of this development are outlined in Adams \& Papa (2000) and Guo (1998). The pdf of runoff volume is;

$$
f\left(v_{r}\right)=\frac{\zeta}{\phi} e^{-\zeta\left[\left(\frac{v_{r}}{\phi}\right)+S_{d}\right]}, \quad v_{r}>0
$$

The expected value $\left(E\left[v_{r}\right], m m\right)$ and average annual volume of runoff $(R, m m)$ are then: 


$$
\begin{aligned}
& E\left[V_{r}\right]=\frac{\phi}{\zeta} \mathrm{e}^{-\zeta S_{d}} \\
& R=\theta \frac{\phi}{\zeta} \mathrm{e}^{-\zeta S_{d}}
\end{aligned}
$$

Where $\theta$ is the average annual number of rainfall events, derived from long-term rainfall data for specific locations (Appendix A). Equation 9 is the main equation that was incorporated into the bulk of the runoff volume calculation and calibration work. Although quite simple it incorporates two important factors, runoff coefficient and depression storage. Once the depth of runoff is known, the corresponding catchment area provides the calculation to obtain the total volume (V) as shown in Equation 9a.

$$
V=\text { Area of Catchment } x \theta \frac{\phi}{\zeta} \mathrm{e}^{-\zeta \zeta_{d}}
$$

It should be noted that this model only generates expected average annual runoff volumes and requires long-term data. The benefit of this simplicity allows all types of users to quickly generate runoff volumes. The equation is easily incorporated into a spreadsheet program that facilitates the calibration with other models and the determination of runoff volumes. Using Equations 9 \& $9 a$ and specific catchment data, the expected annual runoff volume can be calculated from a catchment.

\subsubsection{Peak Flow}

Peak discharge is the maximum flow rate observed during a storm event. While total runoff volume describes how much water flows over a given time, the peak discharge describes the maximum instantaneous flow during a storm event. 
Similar to the analytical models developed for total runoff volumes, peak discharge values can also be determined using derived analytical models. Previous research by Guo (1998) and others was able to transform a hydrograph to a set of analytical expressions to determine peak flow. The peak flow of a triangular hydrograph can be expressed as:

$$
Q_{p}=\frac{2 v_{r}}{t+t_{c}}
$$

With the peak discharge rate $Q_{p}(\mathrm{~mm} / \mathrm{hr})$; runoff volume $v_{r}(\mathrm{~mm})$; rainfall event duration $\mathrm{t}(\mathrm{hr})$; and time of concentration $t_{c}(h r)$. The term $t_{c}$, time of concentration, has several definitions; however, a commonly used definition is adopted. The time of concentration is the time required for runoff to travel from the most remote location of the catchment to the outlet or design point (Guo, 1998). There is a variety of methods to determine $t_{c}$ for a given catchment, grouped into three categories: empirical equations, velocity methods, and kinematic wave theory models. In this research, the $t_{c}$ of the Highland Creek watershed was estimated by using a velocity method. The velocity method is less complex than using the kinematic wave theory and provides suitable values for the analytical analysis. The velocity method (also known as the Uplands method) developed by the Natural Resources Conservation Service (NRCS) was used to determine travel time (Fang et al., 2007; NRCS 1972). The Uplands method determines velocity $(\mathrm{m} / \mathrm{s})$ as a function of slope, type of land cover and travel time, as:

$$
V=k S^{0.5}
$$




$$
t_{c}=\frac{L}{3600 V}
$$

Where $\mathrm{S}$ is the unit-less slope of the catchment and $\mathrm{k}$ is an overland flow coefficient specific to the Uplands method. The length of flow $(\mathrm{m})$ that the water travels within the catchment is represented as L. Empirically developed values of k exist from the National Land Cover Data Overland Flow Coefficients (Fang et al., 2007) and are shown in Table 3-3.

Table 3-3: Overland Flow Coefficients for NRCS Velocity Method (Fang et al., 2007)

\begin{tabular}{|c|c|}
\hline Classification & Coefficient \\
\hline Open water & 15.7 \\
\hline Low intensity residential & 20.4 \\
\hline High intensity residential & 20.4 \\
\hline Commercial/industrial/transportation & 20.4 \\
\hline Bare rock/sand/clay & 7.0 \\
\hline Quarries/strip mines/gravel pits & 7.0 \\
\hline Transitional & 7.0 \\
\hline Deciduous forest & 1.4 \\
\hline Evergreen forest & 1.4 \\
\hline Mixed forests & 1.4 \\
\hline Shrub land & 1.4 \\
\hline Grasslands/herbaceous & 7.0 \\
\hline Pasture/hay & 7.0 \\
\hline Row crops & 4.6 \\
\hline Small grains & 4.6 \\
\hline Urban/recreational grasses & 7.0 \\
\hline Woody wetlands & 15.7 \\
\hline Emergent herbaceous wetlands & 15.7 \\
\hline
\end{tabular}


The time of concentration for a large watershed can be approximated by summing the $t_{c i}$ of the individual sub-catchments within. The general methodology to determine the $t_{c}$ of the Highland Creek includes the following steps:

1. Choose, by visual inspection, several of the longest routes from a subcatchment map.

2. Determine the $t_{c i}$ of each sub-catchment within the route of interest, using the NRCS Velocity method, Equations $11 \& 12$

3. Determine the total $t_{c}$ by summing the $t_{c i}$ from Step 2 for each subcatchment.

4. The catchment $t_{c}$ is the largest value of all the routes examined.

The division of sub-catchments is provided in Appendix $\mathrm{C}$ and corresponding parameters for the Highland Creek watershed are provided by Aquafor Beech (2004), Appendix F.

Using the previously developed rainfall-runoff transformation (Section 3.1.2) and Equation 10, Guo (1998) found that the peak discharge rate can be analytically determined as a set of equations:

$$
Q_{p}=\left\{\begin{array}{c}
0, v \leq S_{d i} \\
\frac{2 h\left(v-S_{d i}\right)}{t+t_{c}}, S_{d i}<v \leq\left(S_{i l}+f_{c} t\right) \\
\frac{2\left[\left(v-S_{d}-f_{c}(1-h) t\right]\right.}{t+t_{c}}, v>S_{i l}+f_{c} t
\end{array}\right.
$$

where $Q_{p}$ is the peak flow $(\mathrm{mm} / \mathrm{hr}) ; v$ is the rainfall event volume $(\mathrm{mm}) ; S_{d i}$ is the depression storage of the impervious area $(\mathrm{mm}) ; h$ is the fraction of impervious area (unit-less); $t$ is the rainfall event duration $(\mathrm{hr}) ; t_{c}$ is the time of concentration $(\mathrm{hr}) ; S_{i l}$ is the initial losses of the pervious areas $(\mathrm{mm}) ; f_{c}$ is ultimate infiltration capacity $(\mathrm{mm} / \mathrm{hr})$; and $S_{d}$ is the area weighted depression storage of a catchment 
$(\mathrm{mm})$. The rainfall event volume $(v)$ and duration $(t)$ is a user-defined parameter and values can be taken from historic records, intensity duration frequency curves, or design storms. The various depression storage values $\left(S_{d,} S_{d i}, S_{i l}\right)$ can be obtained from Table 3-1. The fraction of impervious area in a catchment can be found from the land use or existing inventory data of a catchment. Infiltration of water into the soil is measured by using Horton's equations and infiltration rates (Bedient \& Huber, 2008). The ultimate infiltration capacity is described as the infiltration rate once the soil has been saturated with water and typical values are shown in Table 3-4. The soil type varies over a catchment and can be determined from soil maps for various regions.

\section{Table 3-4: Values for Ultimate Infiltration Capacity (Bedient \& Huber, 2008)}

\begin{tabular}{|c|c|}
\hline Soil Type & $\mathbf{f}_{\mathbf{c}}(\mathbf{m m} / \mathbf{h r})$ \\
\hline Alphalpha loamy sand & 35.6 \\
\hline Carnegie sandy loam & 50.0 \\
\hline Dothan loamy sand & 66.8 \\
\hline Fuquay pebbly loamy sand & 61.5 \\
\hline Leefield loamy sand & 43.9 \\
\hline Tooup sand & 45.7 \\
\hline
\end{tabular}

From the first relation in Equation 13, no flow from the catchment is expected if the rainfall intensity does not exceed the depression storage of the impervious area. This represents a small rainfall where all of the water is caught in pools and other depression storage. Once this depth is exceeded, flow from the catchment is observed from the remainder of the expressions in Equation 13. Depending on the amount of rainfall, the pervious and/or impervious areas may contribute to the peak flow. The boundaries of the second line of Equation 13 show a situation 
where the rainfall event has not exceeded the depression storage and the infiltration capacity of the soil. In this situation the pervious areas are not contributing to the peak flow. Finally, the last expression in Equation 13 shows the scenario when the rainfall event has exceeded a value when both pervious and impervious areas are contributing to peak flow. Further information concerning the probability of peak flow can be found in research by Guo (1998).

Using Equation 13 and the calibrated parameters determined earlier, the peak flow from the Highland Creek was determined. The peak flow was calculated for the base case (no green roofs), 50\% and $100 \%$ green roof scenarios based on the input parameters. The reduction in peak flow from the analytical model was compared with other findings. Aquafor Beech (2004) provided a hydrology update report for the Highland Creek to develop a flood management strategy. This document included peak flow analysis for a variety of storms and was used as a comparison for the analytical model shown in Equation 13. The analytical model was not be calibrated to fit the data found in the Highland Creek hydrology report update.

\subsubsection{Limitations}

Certain limitations are inherent to the development of the analytical model. Rainfall characteristics must be treated as a sample of events from a parent population. This requires a long-term coherent history of rainfall data to approximate. Another assumption is that the rainfall events are independent of one another and stationary. Although rainfall events do depend on weather patterns and are hardly stationary, these assumptions are acceptable and their impacts are small and difficult to quantify (Adams \& Papa, 2000). The analytical model and rainfall parameters only predict the runoff during non-winter months. To account for the 
runoff during non-winter months, another methodology must be used. Since the analytical model is based on statistics, the runoff calculated from Equations 9 and $9 \mathrm{~b}$ represents an average value. This method is best suited for applications requiring long-term data as opposed to determining extreme scenarios.

Peak flow limitations arise from the development of a hydrograph. In reality a hydrograph is a complex and unique curve for a specific catchment. The triangular hydrograph also assumes that rainfall intensity is constant over the storm and that the spatial distribution of rainfall over the catchment is uniform. Extrapolating this method over a large watershed area may increase some of the errors. Increasing the number of individual catchments in the same area may reduce the impact of the uniform assumption.

\subsection{URF Method}

Although the analytical model can determine the total runoff from a catchment, it would have difficulty modelling a multi-land use catchment. This occurs because the analytical model requires area-averaged input parameters and does not consider hydraulic mechanics inside the catchment. Analysis is best done considering single land uses. The URF method or approach adopted by Banerjee (2004), uses a CSM (HSP-F) to determine the hydrological response of a 10 ha catchment representing a single homogeneous land use type (high density residential, commercial, industrial etc.). The URFs also simulate different implementation magnitudes of green roof technology (50\% and 100\%). Overall, each land use type has three corresponding URFs for different scenarios ( $0 \%$ or base, $50 \%$ and $100 \%$ ). The total annual runoff volume of a watershed can then be determined from the aggregation of the different URFs based on the land use areas. 
This total runoff aggregation method can be performed with data from the case study (Highland Creek watershed) as provided by Banerjee (2004) and Maunder (2004). The URF method is linear and assumes that a parcel of land reacts the same from one watershed to another. Developing the URFs can be accomplished by using a CSM or an analytical model. Since the method is simple to use, the applied study has adopted the URF method to determine the hydrological response. Figure 3-4 shows a graphical representation of the URF method and runoff aggregation method.

Figure 3-4: URF and Runoff Aggregation Method
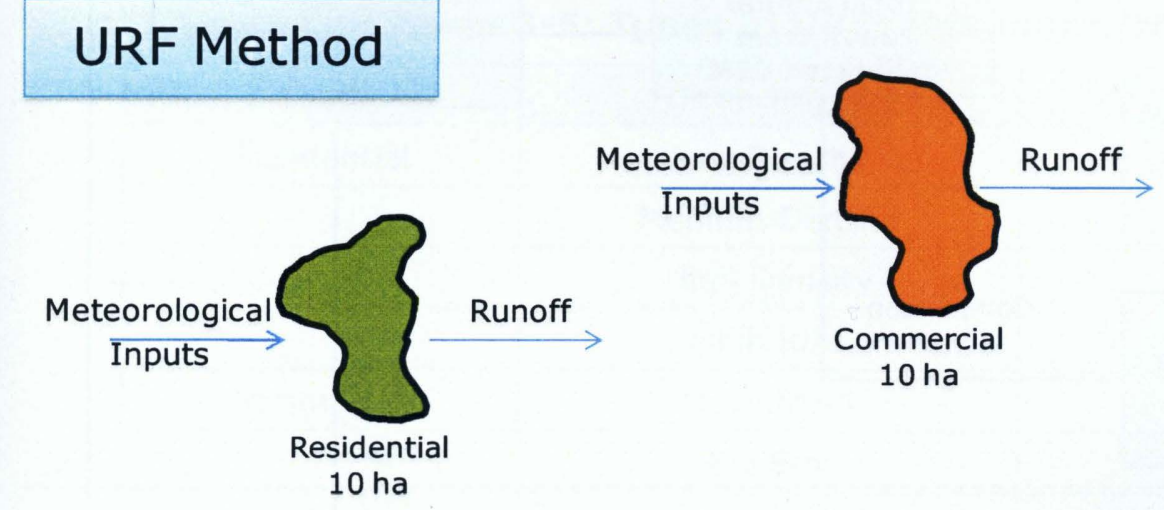

Runoff Aggregation

$$
10 \text { ha }
$$

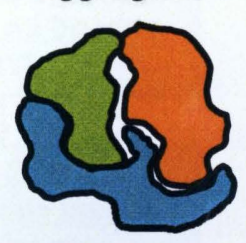

Linear Scaling

\subsection{Calibration of the Analytical Model}

The overall URF development and calibration is outlined in Figure 3-5. The analytical model was calibrated to the HSP-F model developed by Maunder (2004) and Banerjee (2004). The HSP-F model itself was calibrated using observed runoff data. During calibration with green roof technology, the HSP-F model was able to match observed annual runoff volume within $2 \%$ to $10 \%$. This represents a good correlation, so a suitable calibration of the analytical model can be performed using the results of the HSP-F CSM. Although the analytical model is calibrated to the simulation model (which in turn is calibrated to observed data), the percentage 
error in matching observed runoff values is not as important as the percentage reduction in runoff from using green roof technology.

Figure 3-5: URF Development and Calibration

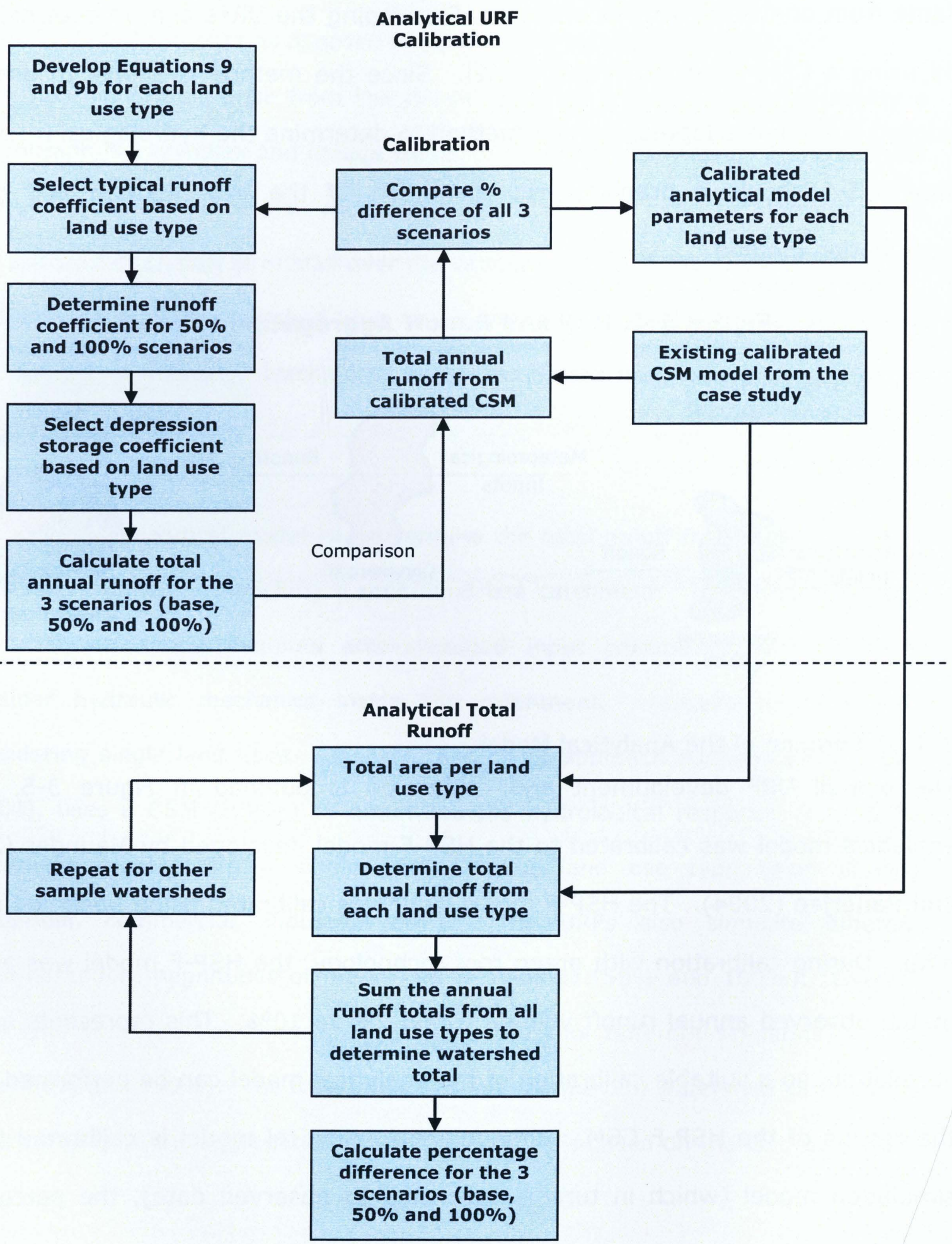


The URFs developed for the HSP-F model of the Highland Creek are divided into land use types with their own corresponding characteristics. They are defined as the hydrological response of a hypothetical homogeneous 10 ha test catchment, representing each land use type, soil and connectivity configurations associated with the known set of meteorological conditions. They vary based on soil type, roof leader connection type, footing drains, etc. The types of URFs are listed in Table 3-5 (see Appendix B for full details of the URFs). The original URF modelling also provides details concerning water quality parameters; however they are not considered in this research.

Table 3-5: Types of URFs (Maunder, 2004)

\begin{tabular}{|c|c|c|}
\hline Type & Description & Code \\
\hline Residential & Low Density & RLD \\
\hline & Medium Density & RMD \\
\hline & High Density & RHD \\
\hline & High Rise & RHR \\
\hline Commercial & Downtown & CDT \\
\hline & Big Box & CBB \\
\hline & Strip Mall & CSM \\
\hline Open Space & Park lands, hydro & EIS \\
\hline & Valley lands, golf/cemetery & OPL \\
\hline Transportation & & OVL \\
\hline Industrial & Prestige & THC \\
\hline & Big Box & IPR \\
\hline
\end{tabular}

The existing land use data and watershed catchment plan are provided Appendix B. Each URF, shown in Table 3-5, has an average annual runoff with respect to three different scenarios based on the practical level of implementation on the roof area. The three scenarios include: 
- no green roofs

- $50 \%$ green roofs

- $100 \%$ green roofs

Each scenario is generated with 6 years of annual runoff volume $\left(\mathrm{m}^{3}\right)$ for each URF, however only the runoff volume for the non-winter months were extracted from the HSP-F model. The analytical model (Equation 9) calculates a depth of runoff and when multiplied by an area (Equation 9a) produces the total runoff volume. The URF model used a uniform area catchment of 10 ha. Using Equation 9b, the total runoff volume for each URF was calculated by varying the runoff coefficient and depression storage. Two runoff coefficients and two depression storage values were first selected, representing the pervious and impervious components. The parameters were selected from a list of appropriate values corresponding to the catchment and land use type as outlined in Table 3-1 and Table 3-2. The pervious and impervious parameters were averaged based on the percentage of impervious and pervious area. Once the area weighted runoff coefficient and depression storage ( $\Phi$ and $S_{d}$ ) were calculated for the base scenario (no green roofs), the other two scenarios were automatically calculated by the inherent change of the roof area (impervious) being converted to a pervious area. This change in pervious area simulates the roof's conversion into a green roof. The method used to determine the change in pervious area is the same as the HSP-F model and assumes that only $75 \%$ of roof areas are capable of supporting green roof technology. This represents a conversion of $37.5 \%$ and $75 \%$ respectively of the total roof area to a pervious area. Using this method, the total runoff volume of all three scenarios is generated at once. The calibration requires that all three scenarios be within a reasonable 
range of the original URF volume. The calibration process is illustrated in Figure 3-6 and performed following the general steps:

1. Select a typical runoff coefficient for the specific URF based on land use

2. Calculate the corresponding runoff coefficients for the $50 \%$ and $100 \%$ green roof cases based on the change in impervious area

3. Select a typical depression storage for the specific URF based on land use

4. Calculated total runoff volume and compare to URF for the 3 scenarios (base, $50 \%$ and $100 \%$ green roof)

5. Using best judgment, modify runoff coefficient and depression storage values to obtain better match with all scenarios

Figure 3-6: Calibration of Analytical URF to HSP-F/URF Data

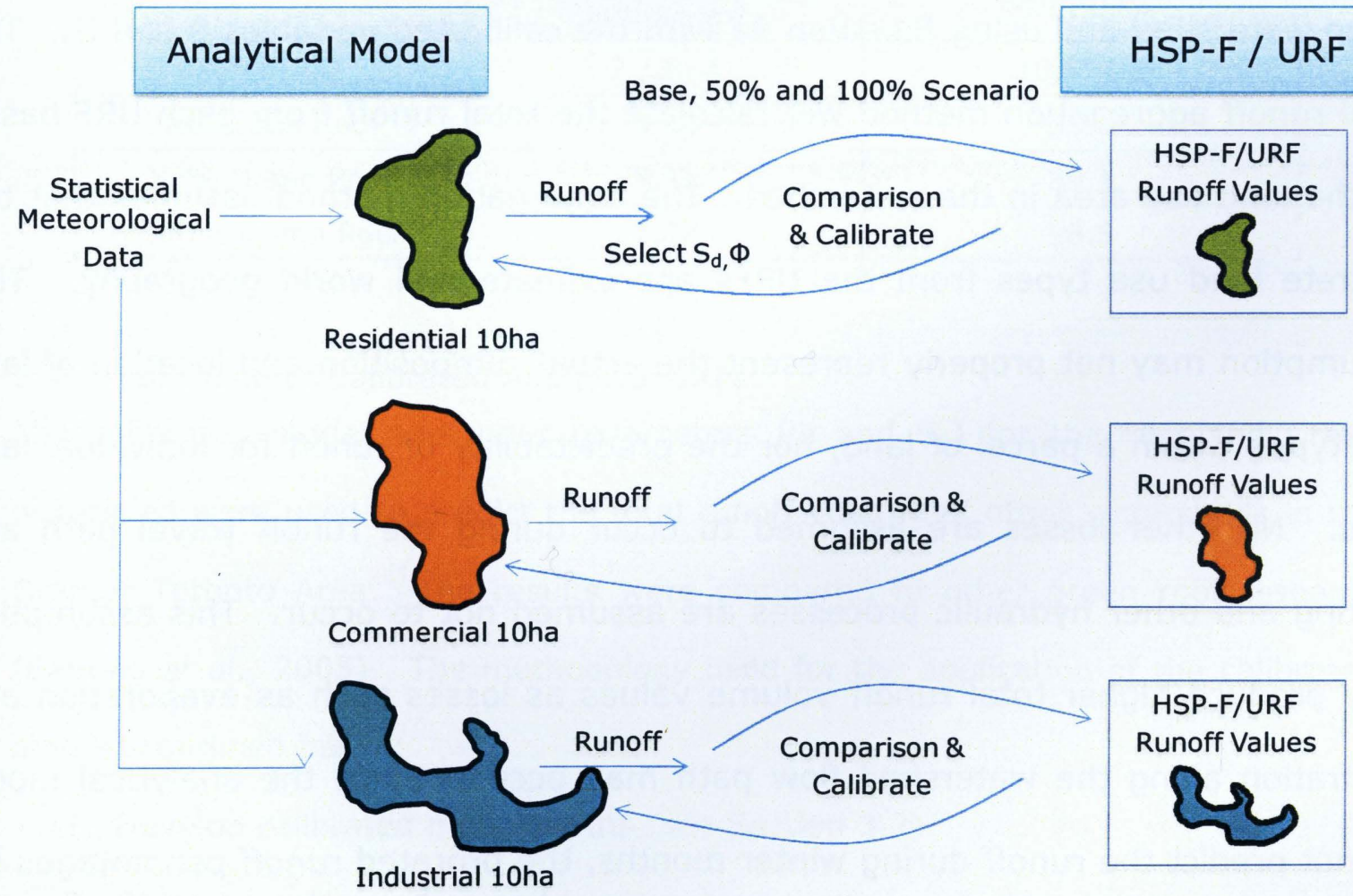

The analytical rainfall parameters (Appendix A) for the Highland Creek only predict the runoff volume during the months of March to November (inclusive). Therefore 
the runoff volumes from the HSP-F/URF model were extracted on a monthly basis and the months of January, February and December were removed from the total. This procedure allowed the total runoff volume from the analytical model to be properly calibrated to the URFs with the same time period. Once the calibration is complete, the percentages of runoff during the months of January, February and December were added back to each analytical URF to generate the final annual total runoff.

\subsubsection{Total Annual Runoff Volume}

Once all of the URFs have a corresponding calibrated analytical URF model, the calibrated parameters ( $\Phi$ and $S_{d}$ ) can be used to determine the total runoff volume from a watershed. This can be accomplished by obtaining the land use areas for a given watershed and using Equation 9a with the calibrated variables $\theta$ and $S_{d}$. The total runoff aggregation method will calculate the total runoff from each URF based on the land use area in the watershed. The aggregation method assumes that the discrete land use types from the URFs approximate real world geography. This assumption may not properly represent the actual composition and location of land use types within a parcel of land, nor the predictability of runoff for individual land uses. No other losses are assumed to occur during the runoff travel path and routing and other hydraulic processes are assumed not to occur. This assumption may produce higher total runoff volume values as losses such as evaporation and infiltration along the watershed flow path may occur. Since the analytical model cannot predict the runoff during winter months, the prorated runoff percentages for the winter months were added. The analytical model cannot estimate the 
groundwater or stream flow of the hydrological cycle. Baseflow data from the TRCA was obtained and used to determine the final total annual runoff volume.

With the total annual runoff volume predicted by the analytical URFs for all three scenarios and the baseflow for the watershed, the percentage reduction due to implementing green roofs with the various scenarios was calculated. Maunder (2004) used the HSP-F model to predict runoff leaving the Markham Branch and the entire Highland Creek watershed with various lévels of green roof implementation. The total runoff volume is summarized in Table 3-6 and was used for comparison to the analytical model.

Table 3-6: HSP-F Predicted Runoff

\begin{tabular}{|c|c|c|}
\hline & $\begin{array}{c}\text { Highland Creek - } \\
\text { Markham Branch } \\
\text { Million } \mathbf{~ m}^{\mathbf{3}}\end{array}$ & $\begin{array}{c}\text { Highland Creek } \\
\text { Million } \mathbf{~ m}^{\mathbf{3}}\end{array}$ \\
\hline Area (ha) & $2,124.4$ & $10,574.5$ \\
\hline No Green Roof & 8.34 & 39.6 \\
\hline $50 \%$ Green Roof & 8.27 & 39.1 \\
\hline $100 \%$ Green Roof & 8.09 & 38.5 \\
\hline
\end{tabular}

\subsection{Application of Calibrated Analytical URFs}

The calibrated model and input parameters $\left(\Phi\right.$ and $S_{d}$ ) for the Highland Creek watershed were used to predict the total runoff volume of other watersheds in the Greater Toronto Area. The results were compared to other green roof research (Banting et al., 2005). The methodology used for the application of the calibrated model is outlined below:

1. Develop calibrated model inputs (see Section 3.3)

2. Obtain runoff volumes and land use composition data for various watersheds in the GTA (Banting et al., 2005) 
3. If required, remap the land use codes to appropriate calibrated model land use codes by averaging similar land use categories

4. Using Equations 9 and $9 b$, determine total aggregate runoff with and without green roofs by inputting the area quantities directly into the calibrated model for each watershed

5. Calculate percentage differences of total runoff volume and runoff volume reduction due to green roof technology

The calibrated model inputs were used with Equation 13 to determine the peak flow of the Highland Creek watershed. These results were compared to TRCA studies and findings. The methodology used to determine the peak flow is outlined below:

1. Develop calibrated model inputs (Section 3.3)

2. Calculate the fraction of impervious $(h)$ area from the land use data provided with the HSP-F model.

3. Calculate area weighted parameters for depression storage $\left(S_{d,}, S_{d i}, S_{i l}\right)$ and ultimate infiltration capacity $\left(f_{c}\right)$ from land use data and calibrated inputs.

4. Calculate the catchment time of concentration $\left(t_{c}\right)$ using Uplands Velocity Method and the sub-catchment data provide by TRCA.

5. Select a rainfall event volume and duration based on the peak flow data provided by the TRCA.

6. Use Equation 13 and calculated variables to determine the peak flow.

The determination of peak flow was not subjected to calibration and was intended for comparison purposes. The HSP-F model performed a brief peak flow analysis 
over a six year period. One of the difficulties in validating the analytical model for peak flow was the scarcity of observed historic peak discharge data for comparison (Guo, 1998). 


\section{Chapter 4}

\subsection{Case Study and Results}

This Chapter outlines the case study and calibration of the analytical model to the data of the Highland Creek watershed. The first series of calibrations were completed to match the URFs and are described in Section 4.1.1. Calculations and comparisons of the annual runoff volume and volume reduction by green roof technology from the calibrated analytical model and HSP-F are outlined in Sections 4.1.2 \& 4.1.3. Results using the calibrated model to predict total annual runoff volume from other watersheds are shown in Section 4.2. Finally, a simple exercise to calculate the peak flow of the Highland Creek was performed and results are shown in Section 4.3. Discussion of the results is included in each section.

\subsection{Case Study: Highland Creek Watershed}

The Highland Creek watershed is described as an "urban creek" by the TRCA (TRCA, 1999). Approximately $85 \%$ of the land area is considered urban, making the watershed the most developed in the TRCA's jurisdiction (TRCA, 1999). With over $75 \mathrm{~km}$ of watercourses, the Highland Creek watershed drains an area of $102 \mathrm{~km}^{2}$. The watershed boundaries are shown in Figure 4-1. 
Figure 4-1: Map of the Highland Creek Watershed (TRCA, 1999)

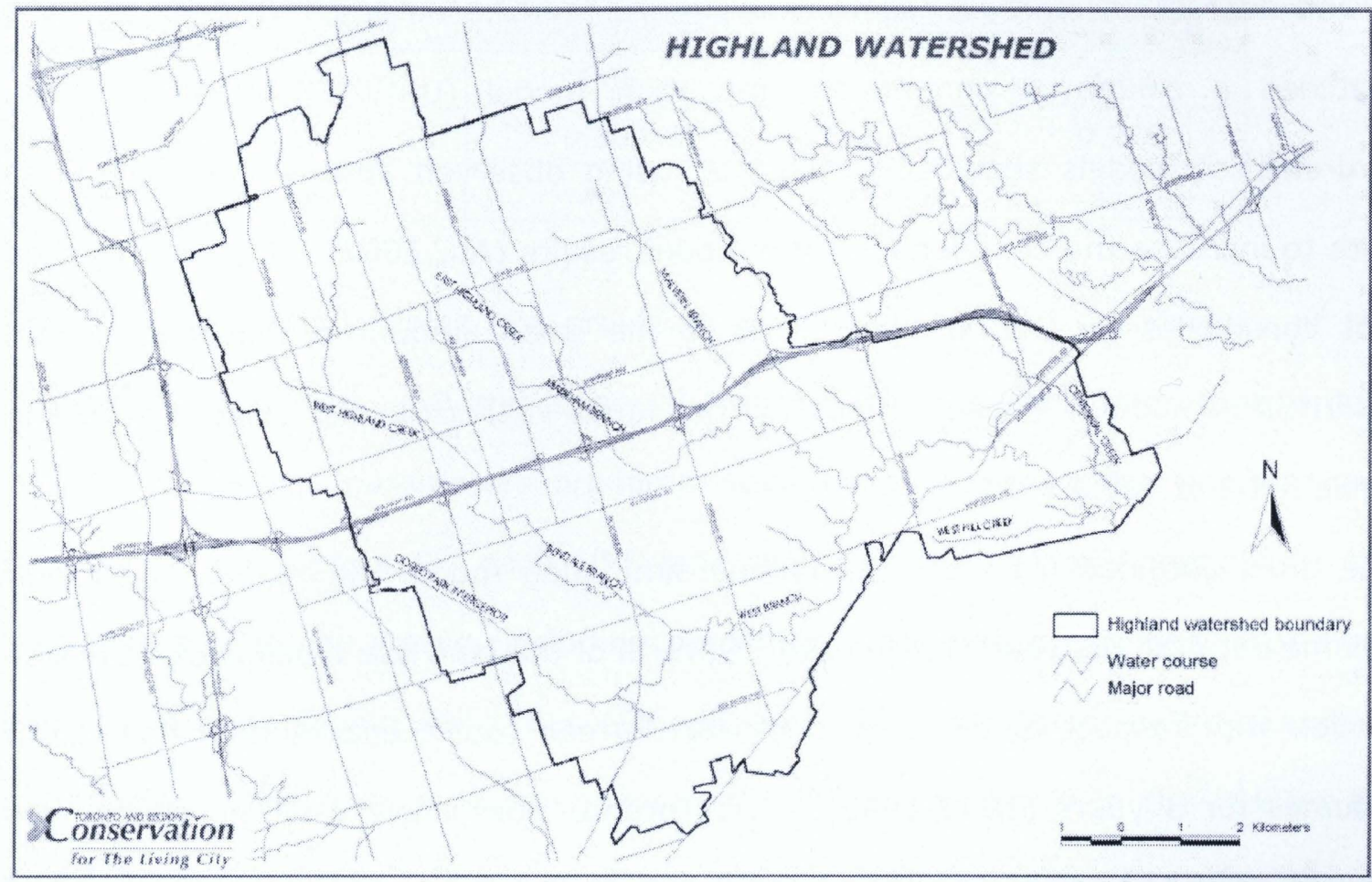

The Highland Creek watershed was chosen as the case study because a CSM had already been calibrated and developed. The CSM also incorporated the implementation of green roof technology. Using the results from the Highland Creek CSM, an analytical model was calibrated. The various calculations and comparisons were performed using a spreadsheet program with area-based determinations from GIS. The calibrated analytical model was used to calculate the total runoff volume and runoff volume reduction from green roof technology implementation on a watershed basis. The results in this chapter are based on the analytical model and tools developed by Adams \& Papa (2000) and Guo (1998) and focus on three (3) parameters of interest in a hydrologic system: total annual runoff, peak flow and total runoff volume reduction. 


\subsubsection{Calibration of URFs}

The calibration consisted of changing the values of model inputs (runoff coefficient $\Phi$ and depression storage, $S_{d}$ ) while trying to produce outputs (total runoff) that matched a calibrated continuous simulation model (URF/HSP-F) within $15 \%$. Hydrological models should be calibrated using observed data or post-calibrated data to increase the confidence of the model results ( $\mathrm{Au}, 2007)$. A simple method was considered for the calibration due to the small amount of field data in the URF/HSP-F model. Typical ranges for the input values $\left(\Phi, S_{d}\right)$ were provided in Table 3-1 and Table 3-2.

The URFs obtained from the continuous simulation model URF/HSP-F had runoff volume data for the years 1990-1996. Several of the land use types within the URF model, with respect to the $50 \%$ and $100 \%$ green roof scenario, only had runoff volumes for 3 years (1990-1992). The Toronto Downsview weather station was chosen as it had more than 20 years of collected data, forming a reliable rainfall data set. The rainfall parameters used are summarized in Table 4-1. Parameters from the Toronto Bloor Street and Ellesmere weather stations were also used with the calibrated model to determine the sensitivity of the parameters. The IETD duration was selected as 1 hour because the URFs are based on a catchment size of 10 ha, which was calculated to have a time of concentration less than 1 hour. 
Table 4-1: Statistical Rainfall Parameters for Analytical Modelling (Adams \& Papa, 2000)

\begin{tabular}{|c|c|c|c|}
\hline \multicolumn{4}{|c|}{ Rainfall Statistics IETD = 1h } \\
\hline Parameter & Downsview & Bloor Street & Ellesmere \\
\hline$\bigvee_{\text {average }}(\mathrm{mm})$ & 3.85 & 4.31 & 4.07 \\
\hline$\zeta\left(\mathrm{mm}^{-1}\right)$ & 0.260 & 0.232 & 0.246 \\
\hline$\theta$ & 114 & 107 & 117 \\
\hline
\end{tabular}

Complete calibration tables are provided in Appendix $D$ and a summary of the calibrated parameters of $\Phi$ and $S_{d}$ are shown in Table 4-2. It is important to note that the calibrated parameters are area-weighted averages of the pervious and impervious parameters for each URF land use. At the top of Appendix D, the parameters used are stated, including percentage impervious/pervious, roof area, depression storage and soil types $(A B, B C$ and $C D)$. As stated in the described methodology, the base parameters for each URF are taken from the master list found in Appendix B. The runoff was then calculated using Equation 9 and multiplied by the sample area size of 10 ha to produce the annual runoff in cubic metres. 
Table 4-2: Calibrated Parameters of $\Phi$ and $S_{d}$

\begin{tabular}{|c|c|c|c|c|c|c|}
\hline \multirow[t]{2}{*}{ URF Type } & \multicolumn{3}{|c|}{$\begin{array}{c}\text { Runoff Coefficient } \\
\Phi\end{array}$} & \multicolumn{3}{|c|}{$\begin{array}{c}\text { Depression Storage } \\
\mathbf{S}_{\mathrm{d}}\end{array}$} \\
\hline & Base & $50 \%$ & $100 \%$ & Base & $50 \%$ & $100 \%$ \\
\hline $\begin{array}{l}\text { Low Density } \\
\text { Residential }\end{array}$ & $0.44-0.50$ & $0.4-0.47$ & $0.37-0.44$ & 0.85 & 0.87 & 0.9 \\
\hline $\begin{array}{l}\text { Med. Density } \\
\text { Residential }\end{array}$ & $0.61-0.65$ & $0.54-0.6$ & $0.48-0.54$ & 0.25 & 0.25 & 0.25 \\
\hline $\begin{array}{l}\text { High Density } \\
\text { Residential }\end{array}$ & $0.76-0.79$ & $0.68-0.72$ & $0.60-0.65$ & 0.15 & 0.17 & 0.19 \\
\hline $\begin{array}{l}\text { High Rise } \\
\text { Residential }\end{array}$ & $0.58-0.6$ & $0.56-0.6$ & $0.53-0.85$ & 0.38 & 0.38 & 0.39 \\
\hline Commercial & 0.99 & $0.92-0.98$ & $0.85-0.97$ & 0.03 & 0.2 & 0.2 \\
\hline $\begin{array}{c}\text { Institutional \& } \\
\text { Educational }\end{array}$ & $0.46-0.52$ & $0.44-0.51$ & $0.42-0.49$ & 1.18 & 1.21 & 1.25 \\
\hline Open Space & \multicolumn{3}{|c|}{$0.13-0.36$} & \multicolumn{3}{|c|}{$2.9-4.9$} \\
\hline $\begin{array}{l}\text { Transportation } \\
\text { Corridor }\end{array}$ & \multicolumn{3}{|c|}{$0.3-0.91$} & \multicolumn{3}{|c|}{3.25} \\
\hline Industrial & $0.83-0.89$ & $0.78-0.89$ & & 0.1 & 0.1 & 0.1 \\
\hline
\end{tabular}

The URF model assumed that no green roofs could be implemented in areas designated as "Open Space" and "Transportation Corridor." For these URFs, the analytical model was only calibrated for the base case. Overall, the calibrated runoff coefficients increased in value with increased impervious land use type. The low-density residential runoff coefficients ranged from 0.54 to 0.66 while the highdensity area ranged from 0.91 to 0.97 . The URFs representing open green space required the lowest coefficients ranging from 0.13 to 0.43 . The calibrated runoff coefficient was higher than expected for the commercial area (base case) and was paired with a small depression storage value. The highest runoff value using the analytical model occurs if the runoff coefficient was 1.0 and the depression storage was 0 . Substituting these two values, the maximum runoff volume was $440 \mathrm{~mm}$ 
per year or $44,000 \mathrm{~m}^{3}$ of total runoff volume on a 10 ha catchment. The average runoff volume predicted by the HSP-F/URF model (Banerjee, 2004) (commercial base case) ranged from $45,222-46,731 \mathrm{~m}^{3}$ per 10 ha, representing values impossible to obtain using the analytical model. This may have occurred because the analytical parameters for rainfall are statistical long-term averages, obtained from a larger dataset. Since the data in the URF/HSP-F model was based on six years, the years 1990-1996 may have had above average rainfall. Reviewing rainfall data from TRCA, the amount of precipitation during the years 1990 to 1996 was $709 \mathrm{~mm}$ (TRCA, 2005). This value was higher than average value predicted by the analytical model parameter of $585 \mathrm{~mm}$, thereby increasing the total annual runoff volume in the HSP-F/URF model. This highlights the importance of ensuring an average dataset is available when using the analytical model.

Each URF has additional characteristics such as roof leader type, soil type, foundation drainage and ditches. The analytical model is not capable of specifically incorporating these parameters. This is a recognized deficiency of using an analytical model, but the goal is to keep the calculations simple. Three different soil types, used in the URF model, are accounted for by using different runoff coefficients. The soil types are classified as $A B, B C$ and $C D$ and lead to three different total runoff volumes as the soils become progressively more resistant to infiltration. Soil $A B$ is a mix of deep sand, deep/shallow loess, aggregated silts, BC is sandy clay, shallow sandy loam and CD soils have significant portions of clay. This amount of detail is appropriate for planning level purposes.

Depression storage followed the same pattern as the runoff coefficients. The less developed land use types such as open space had higher values ranging from 2-5 
$\mathrm{mm}$, while commercial and industrial areas had almost no depression storage. As can be seen in Table 4-2, the depression storage had a range of values, representing different soil and surface conditions. Most of the calibrated depression storage values were lower than typical values seen in Table 4-1. During the calibration process, preference was given to selecting the proper runoff coefficient because of the more sensitive relationship of the variable, based on the results of the sensitivity analysis (Section 4.1.4). The runoff coefficient was given calibration priority by having more precision (up to one decimal place). It also represents the physical change in green roof technology and soil conditions and was determined to be more sensitive.

The average absolute percentage difference between the calibrated analytical runoff model and the URF runoff is summarized in Table 4-3 for each general land use type. Percentage differences can be seen in the calibration worksheets in Appendix D.

Table 4-3: \% Difference of URFs and Calibrated Analytical Model

\begin{tabular}{|c|c|c|c|}
\hline URF Type & $\begin{array}{c}\text { No Green Roof } \\
\mathbf{\%}\end{array}$ & $\begin{array}{c}\mathbf{5 0 \%} \text { Green Roof } \\
\mathbf{\%}\end{array}$ & $\begin{array}{c}\mathbf{1 0 0} \% \text { Green Roof } \\
\mathbf{\%}\end{array}$ \\
\hline Low Density Residential & 2.9 & 6.1 & 2.8 \\
\hline Med. Density Residential & 3.4 & 4.7 & 6.1 \\
\hline High Density Residential & 4.0 & 4.0 & 7.9 \\
\hline High Rise Residential & 3.0 & 4.8 & 3.2 \\
\hline Commercial & 6.5 & 4.3 & 5.9 \\
\hline Institutional \& Educational & 5.9 & 6.2 & 5.5 \\
\hline Open Space & 1.9 & N/A & N/A \\
\hline Transportation Corridor & 0.3 & N/A & N/A \\
\hline Industrial & 8.7 & 5.9 & 10.1 \\
\hline
\end{tabular}


A good match can be found for all URF types. When calibrating, a near perfect match can be made for one of the scenarios, however, the goal was to balance the percentage difference among the three scenarios. The commercial and industrial runoff values from the URF model are larger than the maximum that the analytical model could predict. This occurred because the precipitation data used during 1990 to 1996 was higher than average. This should not greatly impact the overall runoff volume aggregation due to the smaller percentages of commercial and industrial areas in the Highland Creek watershed.

During the calibration process, it was found that the analytical model underpredicted the annual runoff volume when no green roof technology was implemented, and over-predicted the annual runoff volume when green roofs were implemented. This suggests that changing the roof area to a pervious area, to represent the implementation of a green roof does not fully account for all the benefits. Factors that might account for this trend include increased infiltration and evaporation from green roofs. The under-prediction produces conservative estimates when quantifying the runoff reduction when using the analytical model. Changes to the model would be required to account for some of these additional benefits of green roofs.

In addition, the CSM has its own inherent differences when modelling flow patterns and paths. Examples include the residential URFs that had roof leaders disconnected or use of roadside ditches without storm sewers. These URFs produced runoff values less than half of their counterparts (with roof leaders connected to a storm sewer) when using the same runoff characteristics. For example, URF \#1001 (low density residential) had a runoff of about $18,200 \mathrm{~m}^{3}$ 
compared to URF \#1019 (low density residential) with a runoff of about 2,645 $\mathrm{m}^{3}$ in 1990. Both URFs are categorized as low-density residential with an area of 10 hectares, but URF \#1019 includes ditches and disconnected roof leaders. It could be reasoned that much higher depression storage occurs with ditches and that the runoff coefficients are lower due to the increased flow paths over pervious areas. URFs with ditches and roof leaders disconnected were not included in the calibrated due to the large difference in runoff coefficient and depression storage. Their calibration was omitted for this applied study because no areas in the Highland Creek HSP-F model were categorized as such and thus they have no impact on the total annual runoff calculation. The Highland Creek also contains the land use types described as AGR, TRY and EIU (agricultural, transportation, educational land uses); however, the URF/HSP-F models did not use this land type. The analytical model was not calibrated for these land use types and they account for a small percentage of the land use $(<3 \%)$.

\subsubsection{Total Runoff Volume}

Land use in the Highland Creek watershed is broken down by smaller watersheds and outlined in Appendix B. The Highland Creek watershed has about 10,574.5 ha according to the original data used in the HSP-F model (Banerjee, 2004). The total runoff volume aggregation method ignores the land use areas that have not been calibrated (described above). Since one of the objectives is to determine the relative percentage difference in the reduction of runoff due to green roofs, the small amount of land left un-calibrated does not have a major impact. The percentage of area unaccounted for is $5.6 \%$ and assumed as a small amount. 
The total annual runoff determined from the analytical model is summarized in Table 4-4. The calibrated model parameters were combined with the quantities of land use to determine the runoff. This runoff value does not include the runoff during the months of January, February and December, because the analytical URFs were originally calibrated excluding those months. Therefore, the runoff values were prorated accordingly by the percentage calculated earlier in Section 4.1.1, Calibration of URFs. The HSP-F model included a component of flow described as subsurface flow or groundwater flow, which is part of the final total runoff volume at the most downstream part of the watershed. As described earlier, the analytical model (Equations 9 and 9b) does provide a methodology to model the groundwater component of the hydrological cycle. To overcome this shortcoming, average baseflow data for the Highland Creek from the TRCA was included with the analytical model to determine the final outflows of the watershed. Analytical rainfall parameters from the Toronto Bloor and Ellesmere weather station were also used with the calibrated model to determine total flow.

Table 4-4: Total Runoff Volume for the Analytical and HSP-F Models

\begin{tabular}{|c|c|c|c|c|}
\hline Parameter & $\begin{array}{c}\text { Calibrated } \\
\text { Area (ha) }\end{array}$ & $\begin{array}{c}\text { Scenario 1: } \\
\text { No Green } \\
\text { Roofs } \\
\text { Million } \mathbf{~ m}^{\mathbf{3}}\end{array}$ & $\begin{array}{c}\text { Scenario 2: } \\
\mathbf{5 0 \%} \text { Green } \\
\text { Roofs } \\
\text { Million } \mathbf{~ m}^{\mathbf{3}}\end{array}$ & $\begin{array}{c}\text { Scenario 3: } \\
\text { 100\% Green } \\
\text { Roofs } \\
\text { Million } \mathbf{~ m}^{\mathbf{3}}\end{array}$ \\
\hline HSP-F Model & $10,574.5$ & 39.6 & 39.1 & 38.5 \\
\hline $\begin{array}{c}\text { Analytical Model } \\
\text { w/baseflow }\end{array}$ & 9,986 & 42.0 & 40.3 & 38.7 \\
\hline \% Difference & $6 \%$ & $3 \%$ & $0.5 \%$ \\
\hline $\begin{array}{c}\text { Analytical Model } \\
\text { (Bloor Street) } \\
\text { w/baseflow }\end{array}$ & 43.9 & 42 & 40.3 \\
\hline $\begin{array}{c}\text { Analytical Model } \\
\text { (Ellesmere) } \\
\text { w/baseflow }\end{array}$ & 44.5 & 42.6 & \\
\hline
\end{tabular}


The total outflow from the analytical model and HSP-F model show a good match. For comparison purposes, streamflow data from the TRCA for the past 10 years has recorded 35-45 million $\mathrm{m}^{3}$ of total flow from the Highland Creek Watershed. The percentage difference between the HSP-F and analytical model range from $0.5 \%$ to $6 \%$ across the 3 green roof scenarios. These values could be refined by examining how to determine and account for the runoff during winter. Although the original calibration was performed for a period excluding the winter months, the total outflow includes all months. As stated earlier, the runoff during winter months is simply prorated from the total runoff volume. The runoff volume predicted by the analytical model may also be skewed to higher runoff values, since the initial calibration with the URFs was completed with higher than average rainfall data spanning over 6 years. Ensuring that the URFs are calibrated over a more representative time period would increase the confidence of the results. Using the rainfall parameters from other near-by locations, the total annual runoff volume differs by $\sim 5 \%$. Although this difference is small, the rainfall parameters should be reviewed to ensure they reflect the geographic location since rainfall can differ greatly within a small region.

\subsubsection{Runoff Reduction}

The runoff reduction of implementing green roofs is shown in Table 4-5. Although there were a few concerns in developing the total runoff volume (unknown URFs, industrial under-prediction), the calculation of runoff reduction should diminish most of the issues because we are examining the relative differences. 
Table 4-5: Runoff Reduction (Analytical and HSP-F Models)

\begin{tabular}{|c|c|c|}
\hline Parameter & $\begin{array}{c}\text { Scenario 2: } \\
\mathbf{5 0 \%} \text { Green Roofs }\end{array}$ & $\begin{array}{c}\text { Scenario 3: } \\
\mathbf{1 0 0 \%} \text { Green Roofs }\end{array}$ \\
\hline HSP-F Model & $1.3 \%$ & $2.8 \%$ \\
\hline Analytical Model & $4.2 \%$ & $8.0 \%$ \\
\hline
\end{tabular}

The analytical model shows a higher percentage of runoff volume reduction. Additional work by Banting et al. (2005) found that the total runoff volume was reduced by $4.12-12.3 \%$ in a variety of watersheds in the GTA using the URFs developed for Toronto's Wet Weather Flow Study (City of Toronto, 2003). Maunder (2004) performed an HSP-F model on the Markham Branch of the Highland Creek and found that the runoff was reduced by $4 \%$ with green roof technology. The Green Build-out Model found that their modeled intensive green roof scenario prevented $10 \%$ of total annual stormwater from entering the system (Casey Trees \& Limno Tech, 2007). Although others have found that individual green roofs can retain 32-100\% of runoff (Kohler et al., 2002; Moran et al., 2003; Moran et al., 2004; Perry, 2003; Sherman, 2005), the overall watershed effect is lower because of the small amount of land green roofs occupy in a watershed. Although the analytical model does not match well with the HSP-F model for runoff reduction, comparison with other research has shown better matches.

\subsubsection{Sensitivity Analysis}

A simple sensitivity analysis was performed on the analytical model used to predict runoff volumes. The purpose of the analysis was to estimate the rate of change of the model outputs (runoff) with respect to changes in inputs (runoff coefficient $\Phi$ and depression storage, $S_{d}$ ). The method used was the most common sensitivity analysis, a sampling based method that involves running the original model for a 
set of input parameter combinations and determining the sensitivity from the model outputs (Saltelli, 2004). The analytical model or Equation 9 is shown below;

$$
R=\theta \frac{\phi}{\zeta} \mathrm{e}^{-\zeta \varsigma_{\mathrm{d}}}
$$

The variables that were calibrated are $S_{d}$ (depression storage) and $\Phi$ (runoff coefficient), which are dependent on the catchment. The rainfall characteristics $\zeta$ and $\theta$ are constants, which have been tabulated for many major cities and areas in Canada. Due to the simplicity of the model, the sensitivity analysis was not complex and incorporated a minimum, maximum and sampling analysis while holding one of the variables constant.

The runoff coefficient is a unit less measure of the amount of rainfall, in excess of depression storage, that is converted into runoff. Typical values are shown in Table 3-2 and the coefficient has a range from 0 to 1 . Assuming that depression storage is a constant over the watershed, the rate of change for the total runoff volume is:

$$
\frac{d R}{d \phi}=\frac{\theta}{\zeta} \mathrm{e}^{-\zeta S_{d}}
$$

which is a constant value dependent on the statistical rainfall parameters. Figure 4-2 shows the total runoff volume, $R$, and the effect of varying the runoff coefficient, while holding the depression storage constant (for a range of values). The rate of change is constant as shown in the linearity of the resulting curves. The result is a direct relationship between the runoff coefficient and total runoff volume; if the runoff coefficient doubles, so does the total runoff volume. Therefore the runoff coefficient is not more sensitive at any value. 
Figure 4-2: Sensitivity Analysis: Variation of Runoff

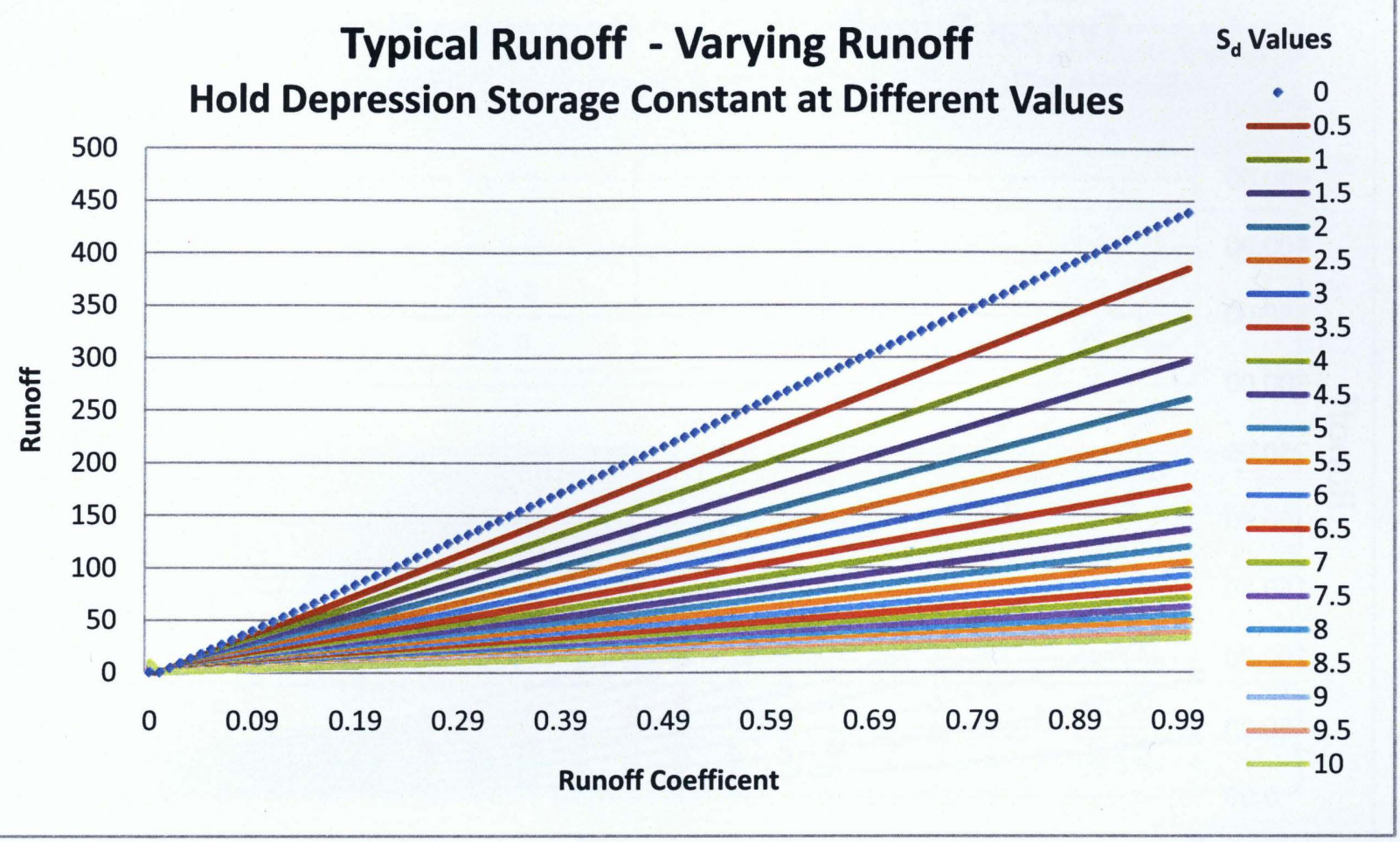

Depression storage cannot be negative and the typical range is $0-7.5 \mathrm{~mm}$ as shown in Table 3-1. Taking Equation (9) and assuming that the runoff coefficient is a constant, the rate of change for the total runoff volume $\mathrm{dR}$ is:

$$
\frac{d R}{d S_{d}}=\left(\theta \frac{\phi}{\zeta}\right)(-\zeta) \mathrm{e}^{-\zeta S_{\mathrm{d}}}
$$

The rate of change is exponentially decaying. Figure 4-3 shows the total runoff volume, $R$, and the effect of varying the depression storage. The rate of change has a higher magnitude when the depression storage is low, such as between the values of 0 and 3. 
Figure 4-3: Sensitivity Analysis: Variation of Depression Storage

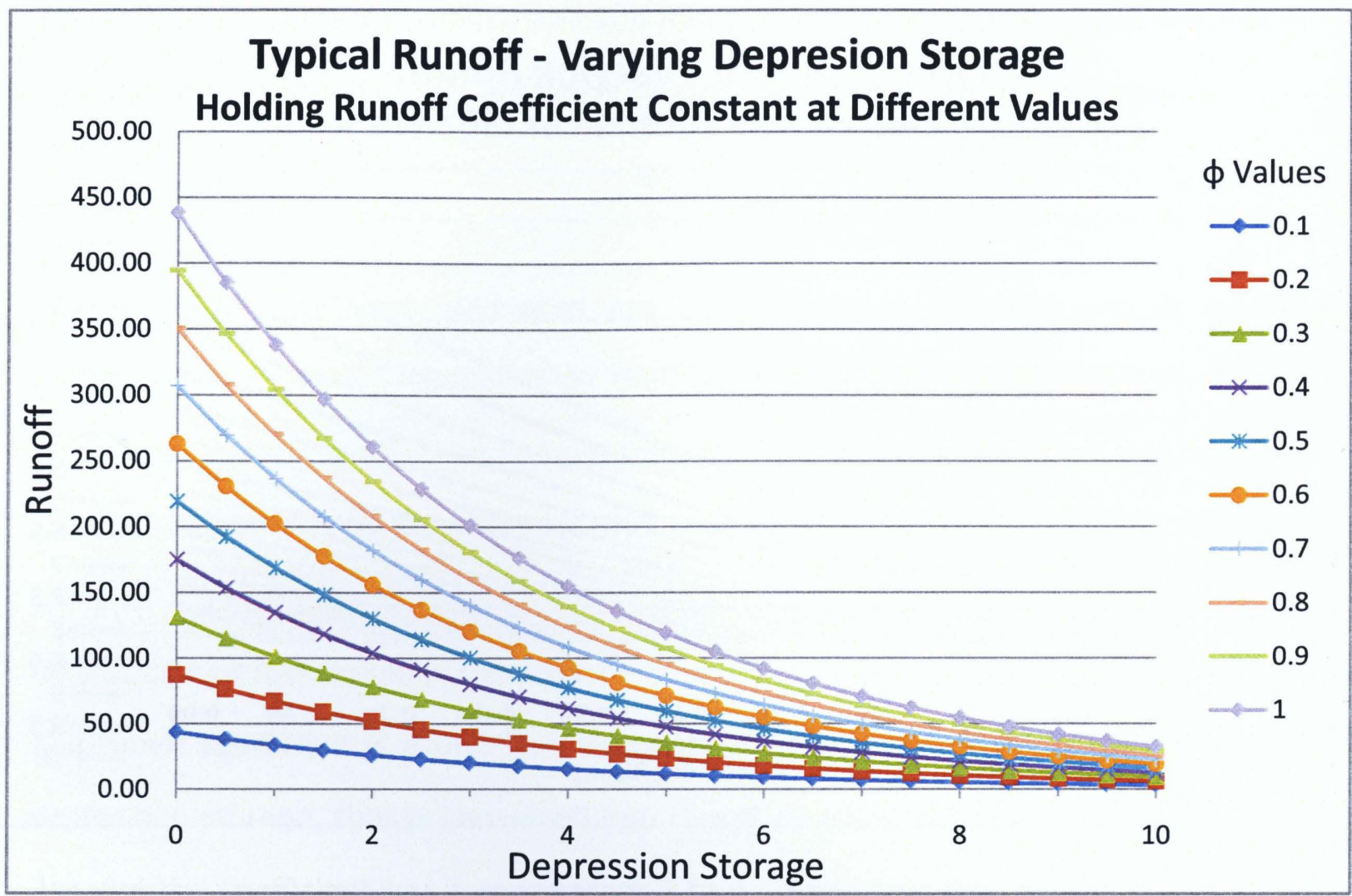

Sampling analysis was performed using a residential high density catchment, $50 \%$ green roof scenario $\left(S_{d}=0.17, \Phi=0.68\right)$. The results of the analysis are shown Table 4-6. 
Table 4-6: Sampling Based Sensitivity Analysis

\begin{tabular}{|c|c|c|c|}
\hline $\begin{array}{c}\text { Runoff } \\
\text { Coefficient } \\
\mathbf{S}_{\mathbf{d}}=\mathbf{0 . 1 7}\end{array}$ & $\begin{array}{c}\text { Total Runoff } \\
\text { Volume }\end{array}$ & $\begin{array}{c}\text { \% Difference } \\
\text { Total Runoff }\end{array}$ & $\begin{array}{c}\text { \% Difference Runoff } \\
\text { Coefficient }\end{array}$ \\
\hline 0.68 & 285.3 & 0 & 0 \\
\hline 0.9 & 377.6 & $32.4 \%$ & $32.4 \%$ \\
\hline 0.45 & 188.8 & $33.8 \%$ & $33.8 \%$ \\
\hline 0.1 & 42.0 & $85.3 \%$ & $85.3 \%$ \\
\hline
\end{tabular}

\begin{tabular}{|c|c|c|c|}
\hline $\begin{array}{c}\text { Depression } \\
\text { Storage } \\
\mathbf{\Phi = 0 . 6 8}\end{array}$ & $\begin{array}{c}\text { Total Runoff } \\
\text { Volume }\end{array}$ & $\begin{array}{c}\text { \% Difference } \\
\text { Total Runoff }\end{array}$ & $\begin{array}{c}\text { \% Difference } \\
\text { Depression Storage }\end{array}$ \\
\hline 0.17 & 285.3 & 0 & 0 \\
\hline 1 & 229.9 & $19.4 \%$ & $47.1 \%$ \\
\hline 2.5 & 155.6 & $45.4 \%$ & $267 \%$ \\
\hline 5 & 81.3 & $71.5 \%$ & $635 \%$ \\
\hline
\end{tabular}

The results from the sampling analysis show that a change in runoff coefficient results in a greater change in the total runoff volume than the depression storage. As shown in the rate of change equation for the runoff coefficient, the derivative is a constant value. A $50 \%$ change in the runoff coefficient results in a $50 \%$ change in the total runoff volume. The relationship with depression storage is different. A much larger change in depression storage must occur before an equal change in total runoff volume is observed.

\subsection{Application of Calibrated Model}

Using Toronto's WWFMMP data and the developed URFs, the reduction of runoff from the implementation of green roof technology was estimated by others (Banting et al., 2005). The predicted runoff with and without green roof technology is summarized in Table 4-7. 
Table 4-7: Runoff Reduction of Various Watersheds (Banting et al., 2005)

\begin{tabular}{|c|c|c|c|c|}
\hline Watershed & $\begin{array}{c}\text { No Green } \\
\text { Roofs } \\
\left(\mathrm{m}^{3}\right)\end{array}$ & $\begin{array}{c}100 \% \\
\text { Implementation } \\
\text { of Green Roof } \\
\left(\mathrm{m}^{3}\right)\end{array}$ & $\begin{array}{c}\begin{array}{c}\text { Runoff } \\
\text { Reduction }\end{array} \\
\left(\mathrm{m}^{3}\right)\end{array}$ & 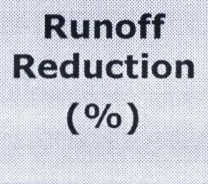 \\
\hline Don River & $34,039,315$ & $31,712,567$ & $2,326,748$ & $6.84 \%$ \\
\hline Don River Main & $8,828,582$ & $8,341,255$ & 487,327 & $5.52 \%$ \\
\hline Don River West & $2,335,424$ & $2,067,991$ & 267,433 & $11.45 \%$ \\
\hline $\begin{array}{c}\text { Eastern Beaches } \\
\text { Tunnel }\end{array}$ & $1,248,587$ & $1,193,737$ & 54,851 & $4.39 \%$ \\
\hline Etobicoke Creek & $4,672,633$ & $4,220,926$ & 451,708 & $9.67 \%$ \\
\hline Highland Creek & $28,169,911$ & $25,976,604$ & $2,193,308$ & $7.79 \%$ \\
\hline Humber River & $28,938,192$ & $26,585,595$ & $2,352,597$ & $8.13 \%$ \\
\hline $\begin{array}{l}\text { Inner Harbour \& } \\
\text { Coatsworth Cut }\end{array}$ & $10,774,454$ & $9,449,024$ & $1,325,430$ & $12.30 \%$ \\
\hline Lake Ontario & $6,864,077$ & $6,245,024$ & 619,053 & $9.02 \%$ \\
\hline Massey Creek & $5,670,812$ & $5,262,666$ & 408,145 & $7.20 \%$ \\
\hline Mimico Creek & $9,200,720$ & $8,366,329$ & 834,391 & $9.07 \%$ \\
\hline Rouge & $5,893,065$ & $5,319,632$ & 573,433 & $9.73 \%$ \\
\hline Waterfront & $3,356,652$ & $3,218,297$ & 138,355 & $4.12 \%$ \\
\hline $\begin{array}{c}\text { Western Beaches } \\
\text { Tunnel }\end{array}$ & $7,641,430$ & $6,993,439$ & 647,991 & $8.48 \%$ \\
\hline
\end{tabular}

The runoff reduction potential of green roofs from this study ranges from $4 \%$ to $12 \%$. Using the analytical model, the runoff reduction of the Highland Creek was estimated at $4 \%$ (50\% green roofs) and $8 \%$ (100\% green roofs) which is within the range of the values developed by Banting et al. (2005) using the $100 \%$ green roof scenario. The calibrated parameters and the analytical model discussed in this report were used to predict the total runoff volume and runoff volume reduction from the same watersheds as shown in Table 4-7. The final results of this comparison are shown in Table 4-8. A complete list of values, including the land 
area of the basins, for total runoff volume without green roof technology is shown in Appendix E.

Table 4-8: Comparison of Runoff Reduction from Using Green Roofs

\begin{tabular}{|c|c|c|}
\hline Watershed & $\begin{array}{c}\text { \% Runoff Reduction } \\
\text { (Banting et al., 2005) }\end{array}$ & $\begin{array}{c}\text { \% Runoff Reduction } \\
\text { Analytical Model }\end{array}$ \\
\hline Don River & $6.84 \%$ & $15.02 \%$ \\
\hline Don River Main & $5.52 \%$ & $9.39 \%$ \\
\hline Don River West & $11.45 \%$ & $13.17 \%$ \\
\hline $\begin{array}{c}\text { Eastern Beaches } \\
\text { Tunnel }\end{array}$ & $4.39 \%$ & $9.05 \%$ \\
\hline Etobicoke Creek & $9.67 \%$ & $10.90 \%$ \\
\hline Highland Creek & $7.79 \%$ & $11.60 \%$ \\
\hline Humber River & $8.13 \%$ & $11.11 \%$ \\
\hline $\begin{array}{c}\text { Inner Harbour } 8 \\
\text { Coatsworth Cut }\end{array}$ & $12.30 \%$ & $10.50 \%$ \\
\hline Lake Ontario & $9.02 \%$ & $12.94 \%$ \\
\hline Massey Creek & $7.20 \%$ & $11.17 \%$ \\
\hline Mimico Creek & $9.07 \%$ & $10.58 \%$ \\
\hline Rouge & $9.73 \%$ & $8.36 \%$ \\
\hline Waterfront & $4.12 \%$ & $10.02 \%$ \\
\hline Western Beaches & $8.48 \%$ & $11 \%$ \\
\hline Tunnel & $8 \%$ & \\
\hline Average Reduction & & 8 \\
\hline
\end{tabular}

The results show that the runoff reduction values generated from the calibrated models exceed the data generated for the GTA watersheds. Relatively good matches were found for the Etobicoke Creek, Inner Harbour \& Coatsworth Cut, Lake Ontario, and Rouge watersheds. In general, the analytical model predicted a greater runoff reduction (11\%) than the work performed by Banting et al. (2005) (8\%). This finding is similar to the initial calibration and comparison in Section 4.1.3. 
The reduction percentage for the watersheds of the Don River, Eastern Beaches Tunnel and Waterfront showed a significant difference. It was expected that the difference in runoff reduction would be smaller, because of the averaging effect of large watersheds in the HSP-F/URF models. One hectare of light residential area in one watershed should behave similar to another one in a nearby watershed. The remapping of land use codes is one source of error because of the uncertainty of the exact land use designation from that source. In addition, the calibrated analytical model has built-in parameters that reflect the characteristics of the Highland Creek Watershed. Applying these characteristics to other watersheds may produce results that do not match well. Since there are no other documented continuous simulations of the other watersheds with green roofs, the comparison of these results should not validate or invalidate the methodology of using an analytical model. As can be seen from the results, both methods are based or calibrated to the HSP-F/URF model of the Highland Creek and produced different results.

\subsection{Peak Flow Analytical Model}

To calculate the peak flow from the Highland Creek watershed, the time of concentration $\left(t_{c}\right)$ was first determined. Using Equations 11 \& 12 and the methodology described earlier, the $t_{c}$ of the Highland Creek was found to be 8.2 hours. The corresponding peak flows from the analytical model (Equation 13) were then determined for all the storm events provided in the Hydrology Update by Aquafor Beech (2004) (Appendix G). The results from Equation 13 are shown in Table 4-9. 
Table 4-9: Results of Analytical Peak Flow

\begin{tabular}{|c|c|c|c|}
\hline $\begin{array}{c}\text { Storm } \\
\text { ID }\end{array}$ & $\begin{array}{c}\text { Peak Flow } \\
\text { Analytical Model } \\
\mathbf{m}^{\mathbf{3} / \mathbf{s}}\end{array}$ & $\begin{array}{c}\text { Peak Flow } \\
\text { Measured Storm } \\
\mathbf{m}^{\mathbf{3} / \mathbf{s}}\end{array}$ & $\begin{array}{c}\text { \% Difference } \\
\text { Analytical/Measured } \\
\%\end{array}$ \\
\hline 1 & 47.8 & 123.0 & $61 \%$ \\
\hline 2 & 44.9 & 87.0 & $48 \%$ \\
\hline 3 & 66.6 & 114.0 & $42 \%$ \\
\hline 4 & 83.1 & 18.0 & $362 \%$ \\
\hline 5 & 44.0 & 22.0 & $100 \%$ \\
\hline 6 & 33.9 & 30.0 & $13 \%$ \\
\hline 7 & 36.2 & 48.0 & $25 \%$ \\
\hline
\end{tabular}

The analytical model used to predict peak flow shows a poor correlation to the measured peak flow events of the Highland Creek. The results show a large range of difference due to the crude development of the input parameters and methodology used in Equation 13. The depression storage and ultimate infiltration capacity are calculated from the area weighted average of the entire catchment. This method does capture how the catchment reacts to peak flow because it is treated as a homogenous parcel of land. The analytical model assumes uniform rainfall intensity, however none of the rainfall events were uniform (Appendix G). During real storms the rainfall intensity varies over time and space. Several of these issues could be resolved by further dividing the sub-catchment of the Highland Creek into smaller and finer catchments with specific input parameters; however, this increases the complexity of using the analytical model. Hydraulic routing of the storm flow is not accounted for in the analytical model; but plays a large role in peak flow determination. Although most of the storms were not closely matched by the analytical model, peak flow for Storm ID 6 and 7 were 
relatively close. Analyzing those two storms, the peak flow reduction of green roof implementation was calculated to range from 11 to $20 \%$.

The peak flow reduction using the analytical model is higher than the $3 \%$ and $4 \%$ as predicted by Maunder (2004). Research is limited on the overall peak flow reduction on a watershed basis. Other studies have found peak flow reductions ranging from 46-90\% from individual green roofs (Moran et al., 2003; Moran et al.,

2004; TRCA, 2005). The underlying basis of the analytical model was to vary the runoff coefficient or the impervious area assuming that available roof area could be switched to a pervious area. Not enough data from other studies are available to validate or compare the results obtained from the peak flow runoff reduction. The results of the peak flow may not be accurate results, however the exercise was easy to complete and may still provide a first estimate of peak flow reduction for planning purposes if additional and long-term data is available for calibration. 


\section{Chapter 5}

\subsection{SUMmARY AND CONCLUSION}

Urbanization has greatly changed the hydrological cycle and stormwater flow patterns, requiring mitigation measures to accommodate excess runoff from rainwater, flooding, erosion and water pollution. The design of urban storm water management systems have greatly evolved with the aid of computerized assistance and models. The design process typically involves running continuous simulation models to predict outputs such as storm runoff volumes, peak flow, water quality parameters, combined sewer overflows etc. During the early stages of urban stormwater design, the final details of the drainage system have yet to be determined. The amount of effort required to generate a continuous simulation model based on unknown variables may not be cost effective. An alternative type of modelling can be used for such instances when a preliminary characterization is required for planning purposes. Based primarily on statistics, analytical modelling can be used during the planning stage of the design. Important parameters during the planning stages for stormwater design include total runoff volume and peak flow for a given catchment.

Green roof technology has been identified as a BMP and increased the use of green roofs within urban drainage systems. Various studies on green roofs have found that they retain and delay stormwater and offer filtering effects to improve water quality. Significant non-hydrological benefits have been studied and identified such as energy savings, air quality improvement and psychological effects, thus providing further support for usefulness of green roofs. Green roof research has mainly focused on evaluating the hydrological reaction of a single green roof to rain 
events. The research is limited on how a series of green roofs performs over a watershed. This study models the hydrological benefits of green roofs over a watershed.

Using the Highland Creek Watershed as a case study, an analytical URF model was developed and calibrated to a CSM (HSP-F) developed by Banerjee (2004). The original work by Banerjee (2004) also included developing URFs for land use types with green roofs. The URF calibration process involved changing the catchment parameters of runoff coefficient and depression storage to match total runoff volume. The analytical URF calibrations were successful, with an overall agreement of less than $8 \%$ difference between the HSP-F model. The calibrated parameters were close to typical values for their corresponding land use. The average percentage difference of annual runoff (not including industrial land use) between the HSP-F URFs and analytical URF model ranged from $3.7 \%$ to $7.8 \%$. A near perfect match was made for the runoff scenario of High Density Residential land (50\% green roof implementation); however, the goal was to balance the percentage difference among the three scenarios: base case (no green roof), $50 \%$ green roofs and $100 \%$ green roofs.

The calibrated analytical URF model and the land use area data of the Highland Creek watershed were used to calculate the annual total runoff volume. Using the aggregation method a good match was obtained when comparing the aggregate runoff volume of the HSP-F and analytical URF model. The percentage difference between the analytical and HSP-F model for total annual runoff (including base flow) from the watershed was $0.5 \%, 3 \%$ and $6 \%$ for the three scenarios. For the total annual runoff volume reduction, the analytical model showed a $4.2 \%$ and 
$8.0 \%$ annual runoff reduction with $50 \%$ and $100 \%$ green roof implementation, respectively. The corresponding runoff reductions from the HSP-F model were $1.3 \%$ and $2.8 \%$. Since the annual runoff volume reduction determines the relative differences between the scenarios, the error and inaccuracies are diminished. Using the calibrated analytical URF parameters, the runoff reductions from additional watersheds across the GTA were calculated, resulting in a range of $8 \%$ to $15 \%$ reduction for the entire region. Other studies have produced values comparable to the analytical model results. For example, Banting et al. (2005) found that the total runoff volume was reduced by $4.12 \%-12.3 \%$ when implementing green roofs in a variety of watersheds in the GTA, and Aquafor Beech (2000) found that the runoff was reduced by $4 \%$ with green roofs within the Markham Branch of the Highland Creek. A conclusive statement concerning the accuracy of the analytical model for runoff volume reduction could not be provided. As indentified earlier, the research on quantifying watershed hydrological benefits of green roofs remains limited.

The additional exercise of determining peak flow using analytical tools did not produce results that agreed well with previous studies. This may be due to the area-averaged parameters used in the analytical peak flow model. This method does not capture how the catchment reacts to peak flow since the catchment is treated as a homogenous parcel of land. Unlike the runoff estimate, which was independent of the routing mechanics, the peak flow estimation using analytical models may suffer from averaging catchment properties, uniform rainfall intensity and lack of routing mechanisms. Using observed data and a calibrated simulation model produced for the Highland Creek Watershed (Aquafor Beech, 2004) as a 
basis for comparison, the analytical peak flow model showed peak flow reduction of 13-363\%. Maunder (2004), using the HSP-F model, determined the instantaneous peak flow volume reduction to be approximately $3 \%$ and $4 \%$ using green roof technology. However, the number of available observations was insufficient to provide rigorous evaluation of the analytical model's results for peak flow reduction. Several key findings of this applied study are presented below:

- The analytical model is simple and does not include all the details of the HSP-F/URF model, such as roof leaders and road side ditches.

- The percentage difference between the analytical and HSP-F model for total annual runoff (including base flow) from the watershed was $0.5 \%, 3 \%$ and $6 \%$ for the three scenarios

- The total annual runoff volume reduction, as predicted by the analytical model showed a $4.2 \%$ and $8.0 \%$ annual runoff reduction with $50 \%$ and $100 \%$ green roof implementation

- The original URF model was based on 6 years of rainfall/runoff data which is not sufficient for long term statistical analysis of average rainfall events.

- The routing mechanics of the HSP-F model and the analytical model differ. Since the analytical model directly transforms the rainfall into runoff, water losses and gains within a watershed is ignored. This impact was minimized in this study by comparing the total runoff total volume over a year and not per event. Routing does not play a significant role when determining the annual runoff; however, it plays a large role during peak flow determination. 
- The sensitivity of the analytical model shows that a much larger change in the depression storage parameter must occur before an equal change in total runoff volume is observed. As such, the runoff coefficient was given calibration priority which may lead to selecting depression storage values outside their normal range.

- Results using the peak flow analytical model did not provide good results. There is a lack of observed long-term peak flow data to perform a calibration.

This study attempted to calibrate an analytical model based on a CSM to produce results for total runoff volume with reasonable accuracy. After successful calibration, the model was then used in two applications to determine the total runoff volume and runoff volume reduction due to green roofs. The results indicate that green roof technology could play a role in stormwater management at the watershed level, although the current research is somewhat limited to provide an adequate comparison. To assist future work and research the following recommendations are provided:

- Refinement and/or modification to the analytical model and tools such as incorporating additional details, additional land use types and ensuring all of the area and land use types are included

- Future use of the analytical URF model should ensure that the original calibration dataset represents a statistically average sample with sufficient long-term data 
- Although the difference in total runoff by selecting analytical rainfall parameters from different geographic locations is small, rainfall can vary greatly within a small region

The analytical model was simple to use, contained within a spreadsheet program. It was designed for quick recalibration and analysis of multiple watersheds. The analytical URF approach provides reasonable, high-level estimates of the hydrologic benefits. Analytical URFs can be generated for any watershed by changing a few parameters. With additional refinements and research, improvements can be made. Therefore, this analytical tool is an effective means for studying the watershed-level effects of implementing green roof technology and other stormwater management practices. The existing green roof projects in North America are mainly isolated, single building efforts within large urban areas. If planners are able to determine the benefits of green roofs under different scenarios, the cities, regions and municipalities may be able to enact policies to encourage the use of green roofs. With further study and refinement of the methods in this study, calibrated analytical URF models can achieve a pivotal role in the development of stormwater management policy. 
Appendix A: Statistical Rainfall Data (IETd 1 hr)

(AdAMS \& PAPA, 2004)

75 
Table B.1 Rainfall Statistics of Rain Season (IETD $=1 \mathrm{~h}$ )

\begin{tabular}{|c|c|c|c|c|c|c|c|c|c|c|c|c|c|}
\hline AES ID & Location & Months & $\begin{array}{l}\text { Years of } \\
\text { Record }\end{array}$ & $\bar{t}(\mathrm{~h})$ & $\lambda\left(\mathrm{h}^{-1}\right)$ & $\bar{b}(\mathrm{~h})$ & $\psi^{a}\left(\mathrm{~h}^{-1}\right)$ & $\psi^{b}\left(\mathrm{~h}^{-1}\right)$ & $\tilde{v}(\mathrm{~mm})$ & $\zeta\left(\mathrm{mm}^{-1}\right)$ & $\bar{i}(\mathrm{~mm} / \mathrm{h})$ & $\beta(\mathrm{h} / \mathrm{mm})$ & $\theta(\# / \mathrm{yr})$ \\
\hline 1018610 & Victoria Gonzales Hts. & $1-12$ & $1960-83$ & 2.69 & 0.372 & 34.3 & 0.0291 & 0.0300 & 2.52 & 0.397 & 0.693 & 1.44 & 236 \\
\hline 1018620 & Victoria Int'l Airport & $1-12$ & $1964-83$ & 3.03 & 0.330 & 29.0 & 0.0373 & 0.0357 & 2.88 & 0.348 & 0.670 & 1.49 & 274 \\
\hline 1108447 & Vancouver Int'l Airport & $1-12$ & $1960-83$ & 3.47 & 0.288 & 26.8 & 0.0373 & 0.0388 & 3.70 & 0.271 & 0.764 & 1.31 & 289 \\
\hline 1108487 & Vancouver UBC & $1-12$ & $1960-83$ & 3.49 & 0.278 & 25.1 & 0.0398 & 0.0415 & 3.94 & 0.254 & 0.772 & 1.30 & 305 \\
\hline 1123970 & Kelowna Airport & $1-12$ & $1968-83$ & 2.25 & 0.444 & 64.9 & 0.0154 & 0.0156 & 1.83 & 0.546 & 0.664 & 1.51 & 130 \\
\hline 3012205 & Edmonton Airport & $4-10$ & $1961-83$ & 2.54 & 0.394 & 47.7 & 0.0210 & 0.0214 & 3.15 & 0.317 & 0.992 & 1.01 & 104 \\
\hline 3031093 & Calgary Airport & $5-10$ & $1960-83$ & 2.42 & 0.413 & 50.4 & 0.0198 & 0.0202 & 3.04 & 0.329 & 1.05 & 0.953 & 84.8 \\
\hline 3033880 & Lethbridge Airport & $4-10$ & $1960-83$ & 2.68 & 0.373 & 71.2 & 0.0141 & 0.0142 & 3.53 & 0.283 & 1.05 & 0.951 & 70.3 \\
\hline 4015320 & Moose Jaw Airport & $4-11$ & $1960-83$ & 2.38 & 0.421 & 65.0 & 0.0154 & 0.0156 & 3.20 & 0.313 & 1.10 & 0.909 & 77.9 \\
\hline 4016560 & Regina Airport & $4-10$ & $1960-83$ & 2.33 & 0.430 & 60.3 & 0.0166 & 0.0169 & 3.14 & 0.319 & 1.12 & 0.895 & 83.7 \\
\hline 4057120 & Saskatoon Airport & $4-10$ & $1960-83$ & 2.24 & 0.446 & 61.1 & 0.0164 & 0.0166 & 2.89 & 0.346 & 1.06 & 0.941 & 82.8 \\
\hline 5023222 & Winnipeg Int'l Airport & $4-10$ & $1960-83$ & 2.40 & 0.416 & 49.9 & 0.0201 & 0.0204 & 3.84 & 0.261 & 1.29 & 0.778 & 100 \\
\hline 6048261 & Thunder Bay Airport & $4-10$ & $1960-83$ & 2.61 & 0.384 & 41.2 & 0.0243 & 0.0249 & 4.01 & 0.249 & 1.23 & 0.810 & 120 \\
\hline 6057592 & Sault Ste Marie Airport & $4-10$ & $1961-83$ & 2.60 & 0.385 & 37.0 & 0.0270 & 0.0278 & 3.70 & 0.270 & 1.13 & 0.881 & 131 \\
\hline 6104175 & Kingston Pumping Stn. & $3-11$ & $1960-83$ & 2.75 & 0.363 & 46.3 & 0.0216 & 0.0221 & 4.04 & 0.247 & 1.21 & 0.829 & 135 \\
\hline 6106000 & Ottawa Int'l Airport & $3-11$ & $1967-83$ & 2.81 & 0.356 & 41.0 & 0.0244 & 0.0250 & 4.01 & 0.249 & 1.23 & 0.812 & 152 \\
\hline 6135638 & Niagara Falls & $3-11$ & $1965-83$ & 2.68 & 0.374 & 46.3 & 0.0216 & 0.0221 & 4.18 & 0.239 & 1.37 & 0.732 & 136 \\
\hline 6139525 & Windsor Airport & $3-11$ & $1960-83$ & 2.69 & 0.371 & 45.0 & 0.0222 & 0.0227 & 4.61 & 0.217 & 1.53 & 0.651 & 140 \\
\hline 6140954 & Brantford MOE & $3-11$ & $1961-83$ & 2.62 & 0.381 & 47.8 & 0.0209 & 0.0214 & 4.17 & 0.240 & 1.36 & 0.735 & 121 \\
\hline 6144475 & London Airport & $3-11$ & $1960-83$ & 2.68 & 0.373 & 40.3 & 0.0248 & 0.0254 & 3.96 & 0.253 & 1.27 & 0.785 & 155 \\
\hline 6153194 & Hamilton Airport & $3-11$ & $1970-83$ & 2.87 & 0.348 & 40.5 & 0.0247 & 0.0253 & 4.19 & 0.239 & 1.26 & 0.794 & 153 \\
\hline 6153300 & Hamilton RBG & $3-11$ & $1962-83$ & 2.65 & 0.378 & 58.3 & 0.0171 & 0.0175 & 4.38 & 0.228 & 1.46 & 0.683 & 109 \\
\hline 6155878 & Oshawa WPCP & $3-11$ & $1960-83$ & 2.47 & 0.405 & 54.5 & 0.0184 & 0.0187 & 3.74 & 0.267 & 1.21 & 0.823 & 114 \\
\hline 6158350 & Toronto Bloor Street & $3-11$ & $1937-83$ & 2.73 & 0.367 & 58.5 & 0.0170 & 0.0174 & 4.31 & 0.232 & 1.38 & 0.724 & 107 \\
\hline 6158443 & Toronto Downsview & $3-11$ & $1964-82$ & 2.50 & 0.400 & 55.9 & 0.0179 & 0.0182 & 3.85 & 0.260 & 1.36 & 0.735 & 114 \\
\hline 6158520 & Toronto Ellesmere & $3-11$ & $1966-83$ & 2.63 & 0.380 & 54.0 & 0.0185 & 0.0189 & 4.07 & 0.246 & 1.33 & 0.751 & 117 \\
\hline 6158525 & Toronto Etobicoke & $3-11$ & $1963-80$ & 2.64 & 0.379 & 53.7 & 0.0186 & 0.0190 & 4.07 & 0.245 & 1.33 & 0.752 & 119 \\
\hline 6158733 & Toronto Int'l Airport & $3-11$ & $1960-92$ & 2.69 & 0.372 & 34.9 & 0.0287 & 0.0295 & 4.05 & 0.247 & 1.31 & 0.763 & 126 \\
\hline 6158740 & Toronto Met. Res. Stn. & $3-11$ & $1965-83$ & 2.56 & 0.391 & 54.8 & 0.0183 & 0.0186 & 3.74 & 0.267 & 1.23 & 0.813 & 118 \\
\hline 6158875 & Trenton Airport & $3-11$ & $1964-83$ & 2.75 & 0.363 & 50.3 & 0.0199 & 0.0203 & 4.09 & 0.245 & 1.24 & 0.808 & 126 \\
\hline 6166450 & Peterborough STP & $4-11$ & $1964-83$ & 2.61 & 0.383 & 42.5 & 0.0235 & 0.0241 & 3.83 & 0.261 & 1.27 & 0.790 & 130 \\
\hline 7016294 & Quebec Airport & $4-11$ & $1961-83$ & 2.96 & 0.338 & 35.7 & 0.0280 & 0.0228 & 4.68 & 0.214 & 1.32 & 0.756 & 154 \\
\hline 7025250 & Montreal Int'l Airport & $3-11$ & $1943-83$ & 2.74 & 0.365 & 37.7 & 0.0265 & 0.0272 & 3.69 & 0.271 & 1.12 & 0.895 & 164 \\
\hline 7025280 & Montreal McGill & $3-11$ & $1960-83$ & 2.86 & 0.350 & 39.0 & 0.0257 & 0.0263 & 4.15 & 0.241 & 1.27 & 0.786 & 157 \\
\hline 8101600 & Fredericton CDA & $4 i i$ & $1960-83$ & 2.96 & 0.338 & 40.1 & 0.0250 & 0.0256 & 4.36 & 0.229 & 1.12 & 0.890 & 139 \\
\hline 8104900 & Saint John Airport & $4-11$ & $1960-83$ & 3.09 & 0.323 & 34.7 & 0.0288 & 0.0297 & 5.39 & 0.185 & 1.13 & 0.888 & 158 \\
\hline 8202200 & Halifax & $3-12$ & $1960-74$ & 3.03 & 0.330 & 38.2 & 0.0216 & 0.0269 & 4.47 & 0.224 & 1.01 & 0.992 & 178 \\
\hline \multirow[t]{3}{*}{8300400} & Charlottetown CDA & $4-11$ & $1960-83$ & 2.36 & 0.424 & 37.4 & 0.0268 & 0.0275 & 4.04 & 0.247 & 0.961 & 1.04 & 145 \\
\hline & Maximum Value & & & 3.49 & 0.446 & 71.2 & 0.0398 & 0.0415 & 5.39 & 0.546 & 1.53 & 1.51 & 305 \\
\hline & Minimum Value & & & 2.24 & 0.278 & 25.1 & 0.0141 & 0.0142 & 1.83 & 0.185 & 0.664 & 0.651 & 70.3 \\
\hline
\end{tabular}

Table B.2 Rainfall Statistics of Rain Season (IETD $=2 \mathrm{~h}$ )

\begin{tabular}{|c|c|c|c|c|c|c|c|c|c|c|c|c|c|}
\hline AES ID & Location & Months & $\begin{array}{l}\text { Years of } \\
\text { Record }\end{array}$ & $\bar{t}(\mathrm{~h})$ & $i\left(\mathrm{~h}^{-1}\right)$ & $\bar{b}(\mathrm{~h})$ & $\psi^{a}\left(\mathrm{~h}^{-1}\right)$ & $\psi^{h}\left(\mathrm{~h}^{-1}\right)$ & $\bar{v}(\mathrm{~mm})$ & $\zeta\left(\mathrm{mm}^{-1}\right.$ & $\bar{i}(\mathrm{~mm} / \mathrm{h})$ & $\beta(\mathrm{h} / \mathrm{mm})$ & $\theta(\# / \mathrm{yr})$ \\
\hline 1018610 & Victoria Gonzales Hts. & $1-12$ & $1960-83$ & 3.71 & 0.269 & 43.6 & 0.0229 & 0.0240 & 3.22 & 0.331 & 0.675 & 1.48 & 185 \\
\hline 1018620 & Victoria Int'l Airport & $1-12$ & $1964-83$ & 4.27 & 0.234 & 37.7 & 0.0265 & 0.0280 & 3.77 & 0.265 & 0.667 & 1.50 & 209 \\
\hline 1108447 & Vancouver Int'l Airport & $1-12$ & $1960-83$ & 4.86 & 0.206 & 34.9 & 0.0287 & 0.0304 & 4.85 & 0.206 & 0.763 & 1.31 & 220 \\
\hline 1108487 & Vancouver UBC & $1-12$ & $1960-83$ & 5.16 & 0.194 & 33.3 & 0.0300 & 0.0319 & 5.29 & 0.189 & 0.771 & 1.30 & 228 \\
\hline 1123970 & Kelowna Airport & $1-12$ & $1968-83$ & 2.90 & 0.345 & 77.6 & 0.0129 & 0.0132 & 2.19 & 0.456 & 0.665 & 1.53 & 109 \\
\hline 3012205 & Edmonton Airport & $4-10$ & $1961-83$ & 3.30 & 0.303 & 57.7 & 0.0173 & 0.0180 & 3.83 & 0.261 & 0.991 & 1.01 & 85.3 \\
\hline 3031093 & Calgary Airport & $5-10$ & $1960-83$ & 3.08 & 0.325 & 59.8 & 0.0167 & 0.0173 & 3.62 & 0.276 & 1.04 & 0.957 & 71.1 \\
\hline 3033880 & Lethbridge Airport & $4-10$ & $1960-83$ & 3.47 & 0.288 & 86.3 & 0.0116 & 0.0119 & 4.29 & 0.233 & 1.04 & 0.961 & 57.8 \\
\hline 4015320 & Moose Jaw Airport & $4-11$ & $1960-83$ & 2.97 & 0.337 & 76.2 & 0.0131 & 0.0135 & 3.76 & 0.266 & 1.11 & 0.898 & 66.3 \\
\hline 4016560 & Regina Airport & $4-10$ & $1960-83$ & 3.03 & 0.330 & 72.8 & 0.0137 & 0.0141 & 3.80 & 0.263 & 1.13 & 0.881 & 69.1 \\
\hline 4057120 & Saskatoon Airport & $4-10$ & $1960-83$ & 2.86 & 0.350 & 72.5 & 0.0138 & 0.0142 & 3.44 & 0.291 & 1.06 & 0.944 & 69.6 \\
\hline 5023222 & Winnipeg Int'l Airport & $4-10$ & $1960-83$ & 3.12 & 0.321 & 60.1 & 0.0166 & 0.0172 & 4.64 & 0.215 & 1.27 & 0.786 & 82.9 \\
\hline 6048261 & Thunder Bay Airport & $4-10$ & $1960-83$ & 3.38 & 0.295 & 49.9 & 0.0200 & 0.0209 & 4.88 & 0.205 & 1.23 & 0.816 & 98.5 \\
\hline 6057592 & Sault Ste Marie Airport & $4-10$ & 1961-83 & 3.53 & 0.283 & 46.3 & 0.0216 & 0.0226 & 4.67 & 0.214 & 1.15 & 0.868 & 104 \\
\hline 6104175 & Kingston Pumping Stn. & $3-11$ & $1960-83$ & 3.68 & 0.272 & 57.5 & 0.0174 & 0.0180 & 5.04 & 0.198 & 1.22 & 0.820 & 108 \\
\hline 6106000 & Ottawa Int'l Airport & $3-11$ & $1967-83$ & 3.73 & 0.268 & 50.8 & 0.0197 & 0.0205 & 4.99 & 0.200 & 1.26 & 0.794 & 122 \\
\hline 6135638 & Niagara Falls & $3-11$ & $1965-83$ & 3.49 & 0.286 & 56.3 & 0.0178 & 0.0184 & 5.11 & 0.196 & 1.38 & 0.724 & 111 \\
\hline 6139525 & Windsor Airport & $3-11$ & $1960-83$ & 3.52 & 0.284 & 54.9 & 0.0182 & 0.0189 & 5.65 & 0.177 & 1.57 & 0.636 & 114 \\
\hline 6140954 & Brantford MOE & $3-11$ & $1961-83$ & 3.45 & 0.290 & 58.4 & 0.0171 & 0.0177 & 5.12 & 0.195 & 1.35 & 0.741 & 98.3 \\
\hline 6144475 & London Airport & $3-11$ & 1960-83 & 3.58 & 0.280 & 49.8 & 0.0201 & 0.0209 & 4.92 & 0.203 & 1.28 & 0.782 & 125 \\
\hline 6153194 & Hamilton Airport & $3-11$ & $1970-83$ & 3.84 & 0.260 & 50.4 & 0.0198 & 0.0207 & 5.24 & 0.191 & 1.27 & 0.788 & 122 \\
\hline 6153300 & Hamilton RBG & $3-11$ & $1962-83$ & 3.45 & 0.290 & 70.9 & 0.0141 & 0.0145 & 5.34 & 0.187 & 1.47 & 0.680 & 89.0 \\
\hline 6155878 & Oshawa WPCP & $3-11$ & $1960-83$ & 3.19 & 0.313 & 65.7 & 0.0152 & 0.0157 & 4.52 & 0.221 & 1.22 & 0.817 & 94.0 \\
\hline 6158350 & Toronto Bloor Street & $3-11$ & $1937-83$ & 3.48 & 0.288 & 70.4 & 0.0142 & 0.0146 & 5.17 & 0.193 & 1.40 & 0.716 & 89.4 \\
\hline 6158443 & Toronto Downsview & $3-11$ & $1964-82$ & 3.25 & 0.308 & 67.7 & 0.0148 & 0.0152 & 4.67 & 0.214 & 1.40 & 0.716 & 93.3 \\
\hline 6158520 & Toronto Ellesmere & $3-11$ & $1966-83$ & 3.47 & 0.288 & 66.3 & 0.0151 & 0.0156 & 5.01 & 0.200 & 1.34 & 0.748 & 95.4 \\
\hline 6158525 & Toronto Etobicoke & $3-11$ & $1963-80$ & 3.46 & 0.289 & 65.7 & 0.0152 & 0.0157 & 5.00 & 0.200 & 1.34 & 0.744 & 96.6 \\
\hline 6158733 & Toronto Int'l Airport & $3-11$ & $1960-92$ & 3.55 & 0.282 & 43.4 & 0.0230 & 0.0236 & 5.00 & 0.200 & 1.32 & 0.758 & 104 \\
\hline 6158740 & Toronto Met. Res. Stn. & $3-11$ & $1965-83$ & 3.39 & 0.295 & 67.3 & 0.0149 & 0.0153 & 4.62 & 0.217 & 1.22 & 0.817 & 95.8 \\
\hline 6158875 & Trenton Airport & $3-11$ & $1964-83$ & 3.64 & 0.274 & $\operatorname{mon}$ & 0.0161 & 0.0167 & 5.06 & 0.198 & 1.26 & 0.791 & 102 \\
\hline 6166450 & Peterborough STP & $4-11$ & 1964-83 & 3.48 & 0.287 & 76 & 0.0191 & 0.0198 & 4.75 & 0.211 & 1.27 & 0.785 & 105 \\
\hline 7016294 & Quebec Airport & $4-11$ & $1961-83$ & 3.89 & 0.257 & & 0.0227 & 0.0238 & 5.79 & 0.173 & 1.36 & 0.735 & 124 \\
\hline 7025250 & Montreal Int'l Airport & $3-11$ & $1943-83$ & 3.66 & 0.273 & 46.7 & 0.0214 & 0.0240 & 4.60 & 0.217 & 1.12 & 0.896 & 132 \\
\hline 7025280 & Montreal McGill & $3-11$ & $1960-83$ & 3.82 & 0.262 & 48.4 & 0.0206 & 0.0216 & 5.18 & 0.193 & 1.29 & 0.774 & 126 \\
\hline 8101600 & Fredericton CDA & $4-11$ & $1960-83$ & 4.09 & 0.244 & 51.3 & 0.0195 & 0.0203 & 5.62 & 0.178 & 1.14 & 0.878 & 108 \\
\hline 8104900 & Saint John Airport & $4-11$ & $1960-83$ & 4.20 & 0.238 & 43.9 & 0.0228 & 0.0239 & 6.86 & 0.146 & 1.14 & 0.877 & 124 \\
\hline 8202200 & Halifax & $3-12$ & $1960-74$ & 4.23 & 0.236 & 49.4 & 0.0203 & 0.0211 & 5.81 & 0.172 & 1.02 & 0.977 & 137 \\
\hline
\end{tabular}


Appendix B: URFs DeVeloped for the HSP-F MOdel

(MAUnder, 2004) 
URF LIST and WDM Slot Numbering

Common HSP-F Unit-Area Response Function Listing

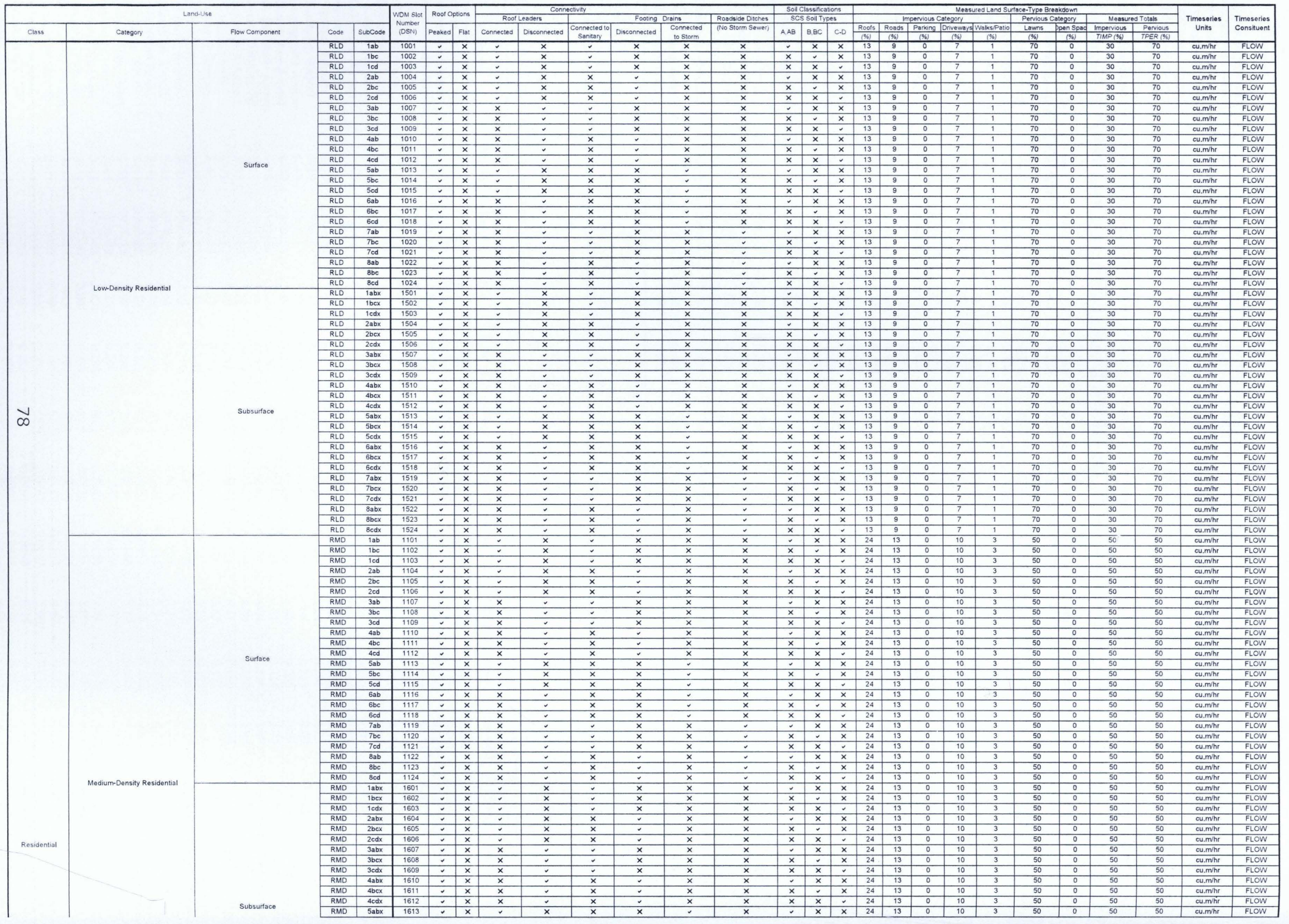

INDEX_URFilistanawOMslots 
URF LIST and WDM Slot Numbering

Common HSP-F Unit-Area Response Function Listing

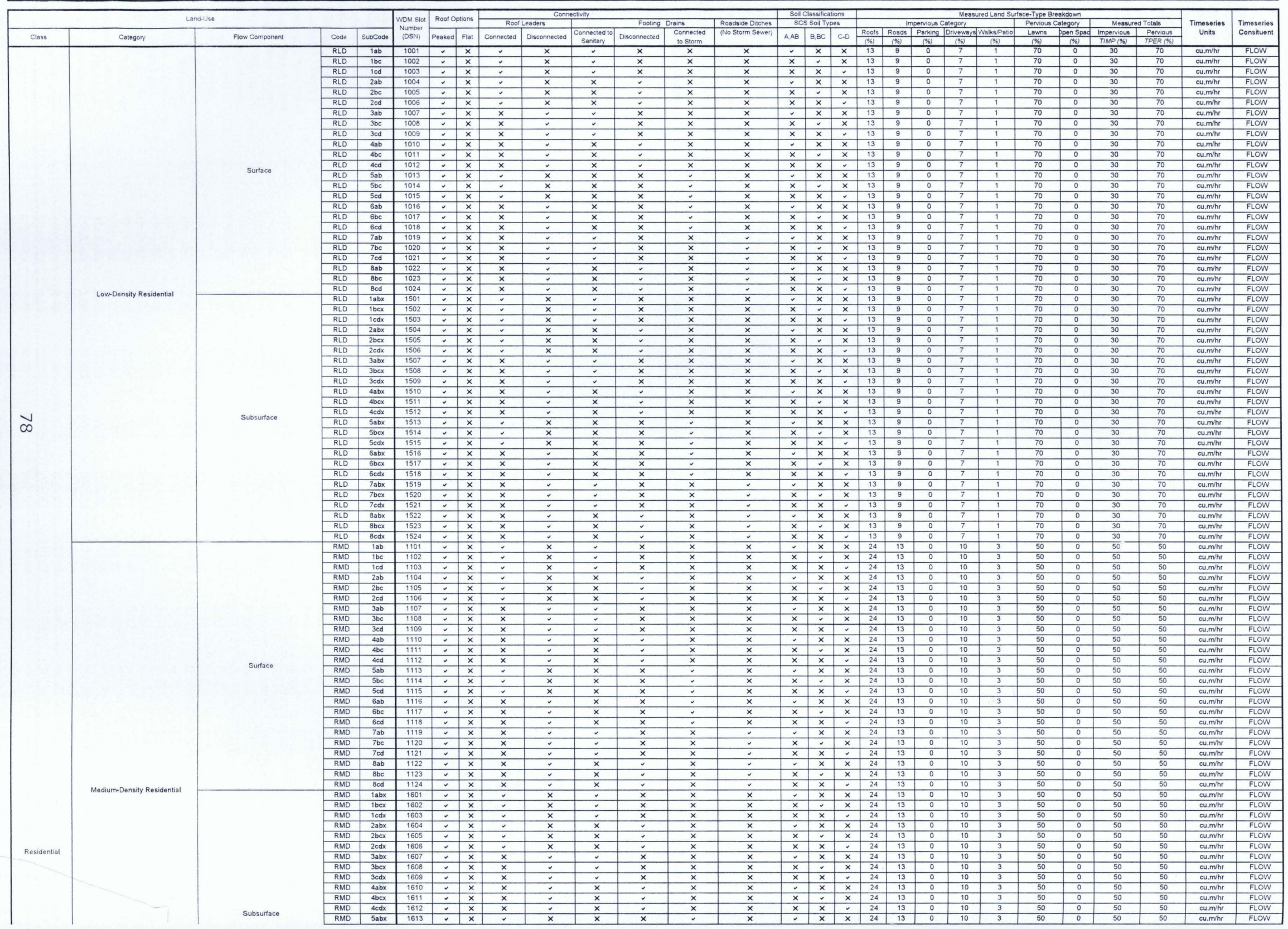




\begin{tabular}{|c|c|c|c|c|c|c|c|c|c|c|c|c|c|c|c|c|c|c|c|c|c|c|c|c|c|c|c|}
\hline \multicolumn{5}{|c|}{ Lanatuse } & \multirow{2}{*}{\begin{tabular}{|l} 
won sloer \\
Number \\
(OSN)
\end{tabular}} & \multicolumn{2}{|c|}{ Root Options } & \multicolumn{2}{|c|}{\begin{tabular}{|l|l} 
Roor Leaserers & Conne \\
\end{tabular}} & \multirow{2}{*}{ 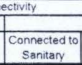 } & \multicolumn{2}{|c|}{ 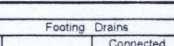 } & \multirow{2}{*}{\begin{tabular}{|l} 
Roadsice Oitches \\
(No Storm Severef \\
\end{tabular}} & \multicolumn{3}{|c|}{\begin{tabular}{|l} 
Sol Classstcitorns \\
scs soil Types \\
\end{tabular}} & \multirow{2}{*}{\multicolumn{7}{|c|}{ 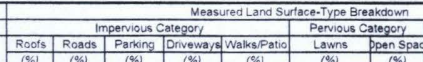 }} & \multirow{2}{*}{\multicolumn{2}{|c|}{\begin{tabular}{|l|l|}
\multicolumn{1}{|c|}{ Measured Totalas } \\
ad
\end{tabular}}} & \multirow{2}{*}{$\begin{array}{c}\text { Timasories } \\
\text { Unts }\end{array}$} & \multirow{2}{*}{\begin{tabular}{|l} 
Timoseries \\
constuent
\end{tabular}} \\
\hline Class & carpony & Flow Component & Code & Sibcode & & Peaked & & Comectied & Discomneteded & & \begin{tabular}{|l|l|} 
Disconnected \\
\end{tabular} & 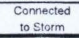 & & $A A B$ & B., Bc & 0.0 & & & & & & & & & & & \\
\hline & \multirow{4}{*}{ Valley Lands. Goll / Cometery } & \multirow{2}{*}{ Surtace } & \begin{tabular}{|l|l} 
OVL \\
OVL
\end{tabular} & $\frac{0 a b}{0 b c}$ & \begin{tabular}{|l|l|}
4102 \\
4102 \\
\end{tabular} & \begin{tabular}{|l|l} 
na \\
$n / a$
\end{tabular} & $\frac{n / 2}{n / 2}$ & \begin{tabular}{|l|l} 
n/a \\
$n / a$
\end{tabular} & $\begin{array}{ll}\mathrm{n} / \mathrm{a} \\
\mathrm{n} \text { na }\end{array}$ & $\frac{n+a}{n / a}$ & $\frac{n}{n / a}$ & $\frac{n+a}{n / a}$ & $\frac{n^{\text {na }}}{\text { naa }}$ & $\dot{x}$ & $x$ & $\begin{array}{l}\frac{x}{x} \\
x\end{array}$ & $\div$ & $\frac{3}{3}$ & $\div$ & $\div$ & $\div$ & $\div$ & $\begin{array}{ll}97 \\
97 \\
\end{array}$ & $\frac{3}{3}$ & $\begin{array}{l}97 \\
97 \\
\end{array}$ & 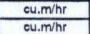 & $\frac{\text { Flow }}{\text { FLOW }}$ \\
\hline & & & OVL & ood & 4103 & nat & n/a & $\pi / a$ & $n / a$ & $n / a$ & $n / a$ & n/a & $\frac{n_{0}}{n_{2}}$ & $\frac{1}{x}$ & $x$ & $x$ & $\div$ & 3 & 0 & 0 & 0 & 0 & $\frac{31}{97}$ & $\frac{5}{3}$ & $\frac{17}{97}$ & 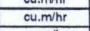 & rLow \\
\hline & & \multirow{2}{*}{ Subsurface } & $\begin{array}{ll}\text { OVL } \\
\text { OVL }\end{array}$ & $\frac{O a b x}{O b c x}$ & 46602 & $\frac{n n^{n / a}}{n / a}$ & $\frac{n / 0}{n / 2}$ & $\frac{n+a}{n / a}$ & $\frac{n / a}{n / a}$ & $\frac{n / a}{n / a}$ & 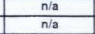 & $\frac{n / a}{n / a}$ & $\frac{n^{n / a}}{n / a}$ & $\dot{x}$ & $\underline{x}$ & $\frac{x}{x}$ & $\div$ & $\frac{3}{3}$ & $\frac{0}{0}$ & $\div$ & $\div$ & $\div$ & 97 & $\frac{3}{3}$ & $\begin{array}{l}97 \\
97 \\
\end{array}$ & $\begin{array}{ll}\text { counhrt } \\
\text { cumphr }\end{array}$ & $\begin{array}{l}\text { Flow } \\
\text { FLOW }\end{array}$ \\
\hline \multirow{6}{*}{ Transpontation } & & & $\begin{array}{ll}\text { OVL } \\
\text { HC }\end{array}$ & ocdx & 4603 & n/a & $n / 2$ & n/a & n/a & $n / a$ & $n / a$ & $n / a$ & na & $x$ & $x$ & 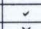 & 0 & 3 & 0 & 0 & 0 & 0 & 97 & 3 & 97 & cu.m/hr & FLOW \\
\hline & \multirow{4}{*}{ Highway Corridors } & \multirow{2}{*}{ surtace } & $\frac{T H C}{T H C}$ & $\frac{0 a b}{0 b c}$ & $\frac{501}{5002}$ & $\begin{array}{ll}n \text { n/a } \\
\text { n/a }\end{array}$ & $\frac{n \pi / 2}{n / 2}$ & $\frac{n / a}{n / 2}$ & $\frac{n / a}{n / a}$ & $\frac{\mathrm{n} / \mathrm{a}}{\mathrm{n} / \mathrm{a}}$ & $\frac{n / a}{n / a}$ & $\begin{array}{c}n / a \\
n / a \\
\end{array}$ & $\frac{n \text { na }}{n / a}$ & $\dot{x}$ & $x$ & $\begin{array}{l}\frac{x}{x} \\
x\end{array}$ & $\div$ & $\begin{array}{l}\text { variable } \\
\text { varable } \\
\end{array}$ & $\div$ & $\div$ & $\div$ & $\div$ & $\begin{array}{l}\text { variable } \\
\text { variable } \\
\end{array}$ & $\begin{array}{l}\text { Variable } \\
\text { variablo }\end{array}$ & $\begin{array}{l}\text { variable } \\
\text { variable }\end{array}$ & 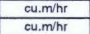 & $\begin{array}{l}\text { FLoW } \\
\text { LLOW }\end{array}$ \\
\hline & & & THC & occ & $\frac{5002}{5003}$ & n/a & $\frac{n / 2}{n / 2}$ & $\frac{n / 3}{n / a}$ & $\frac{n a}{n / a}$ & $\frac{n_{0} / \mathrm{a}}{n_{\mathrm{a}}}$ & $\frac{n / a}{n / a}$ & nia & $\frac{n_{2}}{n / a}$ & $\frac{x}{x}$ & $x$ & & 0 & 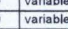 & & 0 & 0 & & $\begin{array}{l}\text { varable } \\
\text { variable }\end{array}$ & $\begin{array}{l}\text { varaboblo } \\
\text { variable }\end{array}$ & $\begin{array}{l}\text { varafable } \\
\text { variable }\end{array}$ & $\frac{c u m h t}{\text { cuumhrt }}$ & FLOW \\
\hline & & & THC & Oabx & 5501 & n/a & $n / 2$ & n/a & $n / a$ & n/a & $n / a$ & $n / a$ & n/a & $\because$ & $x$ & $x$ & 0 & 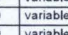 & 10. 0 & 0 & 0 & 0 & variable & variable & $\begin{array}{l}\text { variable } \\
\text { valus }\end{array}$ & ou.mhr & FLOW \\
\hline & & Subsurface & THC & $\begin{array}{l}0 \mathrm{bcx} \\
0 \mathrm{~d} d \mathrm{x}\end{array}$ & \begin{tabular}{|l}
5502 \\
5503 \\
\end{tabular} & nt/a & $\frac{n / 2}{n / 2}$ & $\frac{n+3}{n / a}$ & $\frac{n / a}{n / a}$ & $\begin{array}{l}n / a \\
n / a\end{array}$ & $\frac{n / a}{n / a}$ & $\begin{array}{l}n / a \\
n / a\end{array}$ & $\frac{n=a}{n / a}$ & $\frac{x}{x}$ & $x$ & $x$ & 0 & $\begin{array}{l}\text { varabale } \\
\text { variable }\end{array}$ & 1e. 0 & 0 & 0 & 0 & $\begin{array}{l}\text { variable } \\
\text { variable }\end{array}$ & $\begin{array}{l}\text { variable } \\
\text { variable }\end{array}$ & $\begin{array}{l}\text { vaviable } \\
\text { variable }\end{array}$ & $\begin{array}{l}\text { cummhr } \\
\text { cunmhr }\end{array}$ & $\begin{array}{l}\text { FLoW } \\
\text { FLOW }\end{array}$ \\
\hline & & & IPR & lab & $\frac{5003}{6001}$ & $x$ & 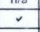 & w & $\frac{m a}{x}$ & a & $\frac{x}{x}$ & n/a & $\frac{m a}{n / a}$ & $\frac{x}{y}$ & $\frac{x}{x}$ & $x$ & 30 & 7 & 43 & 0 & 0 & 20 & 0 & $\frac{10}{80}$ & $\frac{10}{20}$ & $\begin{array}{l}\text { cumimnt } \\
\text { cuumbr }\end{array}$ & FLOW \\
\hline & & Surtace & IPR & ibc & 6002 & $x$ & $\sigma$ & 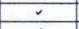 & $x$ & 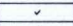 & $x$ & $n / a$ & n/a & $x$ & $\because$ & $x$ & 30 & 7 & 43 & 0 & 0 & 20 & 0 & 80 & 20 & eu.mint & FLOW \\
\hline & Prestige Industrial & & $\frac{\mid P R}{P R R}$ & $\frac{10 \mathrm{~d}}{1 \mathrm{abx}}$ & $\begin{array}{l}6003 \\
6501 \\
\end{array}$ & $\begin{array}{l}x \\
x \\
x\end{array}$ & 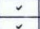 & $i$ & $\begin{array}{l}x \\
x \\
x\end{array}$ & 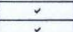 & $\begin{array}{l}x \\
x\end{array}$ & $n / a$ & $\frac{n / 8}{n / 2}$ & $x$ & $\begin{array}{l}x \\
x \\
x\end{array}$ & $\ddot{x}$ & 30 & 7 & 43 & 0 & 0 & 20 & 0 & 80 & 20 & cu.m/hr & FLOW \\
\hline Industrial & & Subsurface & $\begin{array}{l}I P R \\
P R R\end{array}$ & $\begin{array}{l}1 \mathrm{abx} x \\
\mathrm{bcc} x\end{array}$ & $\frac{6501}{6502}$ & $\begin{array}{l}x \\
x \\
\end{array}$ & $\because$ & $\because$ & $\begin{array}{l}x \\
x\end{array}$ & $\because$ & $\begin{array}{l}x \\
x\end{array}$ & $\begin{array}{l}n / a \\
n / a\end{array}$ & $\begin{array}{l}n / \mathrm{n} / \mathrm{a} \\
\mathrm{n} / \mathrm{a}\end{array}$ & $\dot{x}$ & $x$ & \begin{tabular}{|l}
$x$ \\
$x$
\end{tabular} & \begin{tabular}{|l|l|}
30 \\
30
\end{tabular} & $\frac{7}{7}$ & $\frac{43}{43}$ & 0 & 0 & $\frac{20}{20}$ & 0 & $\frac{80}{80}$ & $\frac{20}{20}$ & $\begin{array}{l}\text { cummhr } \\
\text { cunmhr }\end{array}$ & $\begin{array}{l}\text { Flow } \\
\text { FoW }\end{array}$ \\
\hline & & Subsurace & & $1 \mathrm{cdx}$ & 6503 & & $\because$ & & $x$ & r & & $n$ & $\frac{n / a}{n / a}$ & $\frac{x}{x}$ & $x$ & $x$ & \begin{tabular}{|l|}
30 \\
30
\end{tabular} & 7 & $\frac{43}{43}$ & 0 & 0 & 20 & 0 & 80 & 20 & $\begin{array}{l}\text { cumimhr } \\
\text { cummir }\end{array}$ & $\begin{array}{l}\text { FLOW } \\
\text { FLOW }\end{array}$ \\
\hline & Big Box industrial & Surface & 188 & $1 \mathrm{bc}$ & 6101 & $x$ & $\because$ & $\because$ & $x$ & $\because$ & $x$ & na & n/a & $x$ & 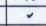 & $x$ & 45 & 6 & 42 & 0 & 0 & 7 & 0 & 93 & 7 & $\begin{array}{l}\text { cumimn } \\
\text { cus.mhr }\end{array}$ & FLOW \\
\hline & Big Eox thaustral & Subsurface & 1BB & $1 \mathrm{bcc} x$ & 6601 & $x$ & 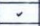 & 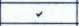 & $x$ & $\because$ & $x$ & $n / a$ & n/a & $x$ & - & $x$ & 45 & 6 & 42 & 0 & 0 & 7 & 0 & 93 & 7 & cu.m/hr & FLOW \\
\hline & & & AGT & Oab & 7001 & n/a & n/a & $n / a$ & $n^{\prime / a}$ & n/a & n/a & nia & $n / 2$ & $\sigma$ & $x$ & $x$ & 0 & 0 & 0 & 0 & 0 & 0 & 100 & 0 & 100 & cu.mhr & FLOW \\
\hline & & Surtace & AGT & $o b c$ & 7002 & n/a & $n / 0$ & $n / a$ & n/a & n/a & nta & $n / a$ & n/a & $x$ & 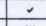 & $x$ & 0 & 0 & 0 & 0 & 0 & 0 & 100 & 0 & 100 & cuumhr & FLOW \\
\hline & Tilled & & AGT & ocd & $\begin{array}{l}7003 \\
7501\end{array}$ & nia & n/a & n/a & $\mathrm{n} / \mathrm{a}$ & n/a & $n / a$ & n/a & n/a & $x$ & $x$ & $\therefore$ & 0 & 0 & 0 & 0 & 0 & 0 & 100 & 0 & 100 & ou.mhr & FLOW \\
\hline & Fiva & & $\begin{array}{l}A G T \\
A G T\end{array}$ & Oabx & $\begin{array}{l}7501 \\
7502 \\
\end{array}$ & na & $\pi / 3$ & n/a & n/a & n/a & $n / a$ & nia & $n^{n / a}$ & $\dot{x}$ & $x$ & $\frac{x}{x}$ & 0 & 0 & 0 & 0 & 0 & 0 & 100 & 0 & 100 & 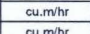 & $\begin{array}{l}\text { FLOW } \\
\text { FLW }\end{array}$ \\
\hline & & Subsurface & $\begin{array}{l}A G T \\
A G T\end{array}$ & $\frac{O b c x}{0 c d x}$ & $\begin{array}{l}7502 \\
7503 \\
\end{array}$ & $\frac{n n^{n}}{n / a}$ & $\frac{n / 3}{n / 3}$ & 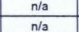 & $\frac{n / a}{n / a}$ & $\frac{n / 3}{n / 3 / 3}$ & $\frac{n / a}{n / a}$ & $\frac{n / a}{n / a}$ & $\frac{n}{n / a}$ & $\frac{x}{x}$ & $\dot{x}$ & $x$ & $\div$ & 0 & 0 & 0 & 0 & $\div$ & 100 & 0 & 100 & $\begin{array}{ll}\text { cummhr } \\
\text { sumbre }\end{array}$ & FLOW \\
\hline Agricultural & & & $\frac{A G P}{A G P}$ & $\frac{0.0 \mathrm{da}}{0.0 \mathrm{~b}}$ & $\frac{7503}{7101}$ & $\begin{array}{ll}n_{\mathrm{a}} \\
\mathrm{n}^{2} \mathrm{a}\end{array}$ & $\frac{n_{3}}{n^{2}}$ & $\begin{array}{ll}n / 3 \\
n / 2\end{array}$ & $\begin{array}{ll}\mathrm{n} / \mathrm{a} \\
\mathrm{n} / \mathrm{a}\end{array}$ & $\begin{array}{l}n+1 / 2 \\
n / a \\
\end{array}$ & $\frac{n / a}{n / a}$ & $\frac{n+3 / 3}{n / 3}$ & 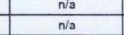 & $\frac{x}{y}$ & $\frac{x}{x}$ & $x$ & $\div$ & 0 & 0 & 0 & 0 & 0 & $\frac{100}{100}$ & 0 & 100 & $\frac{c u, m / h r}{\text { cum mhr }}$ & $\begin{array}{l}\text { FLOW } \\
\text { LOOW }\end{array}$ \\
\hline & & Surtace & $A G P$ & $a b c$ & 7102 & n/a & $n / a$ & $n / a$ & $n / a$ & $n / a$ & $n / a$ & n/a & n/a & $x$ & $\hat{i}$ & $\hat{x}$ & 0 & 0 & 0 & 0 & 0 & 0 & 100 & 0 & 100 & cu.mont & FLOW \\
\hline & Pasturefifallow & & $A G P$ & ocd & 7103 & n/a & nis & n/a & n/a & n/a & n/a & n/a & n/a & $x$ & $x$ & $\therefore$ & 0 & 0 & 0 & 0 & 0 & 0 & 100 & 0 & 100 & cu.m/hr & FLOW \\
\hline & & & $\frac{A G P}{A G^{P}}$ & $\frac{0 a b x}{0 \text { back }}$ & 7601 & n/a & n/a & $n / a$ & $\mathrm{n} / \mathrm{a}$ & n/a & n/a & n/a & n/a & i & $x$ & $x$ & 0 & 0 & 0 & 0 & 0 & 0 & 100 & 0 & 100 & cu.mhr & FLOW \\
\hline & & Subsurface & $\frac{A G P}{A G P}$ & $\frac{0 b x}{0 c d x}$ & $\begin{array}{l}7602 \\
7603\end{array}$ & $\frac{n}{n / a}$ & $\frac{n=1 / a}{n / a}$ & $\frac{n / a}{n / a}$ & $\frac{\mathrm{n} / \mathrm{a}}{\mathrm{n} / \mathrm{a}}$ & $\frac{\text { na }}{n / a}$ & $\frac{n / a}{n / a}$ & $\frac{\text { nas }}{n \text { nala }}$ & $\begin{array}{ll}n / a \\
n / a\end{array}$ & $\frac{x}{x}$ & $\dot{x}$ & $x$ & $\div$ & 0 & 0 & 0 & 0 & 0 & $\frac{100}{100}$ & 0 & 1000 & 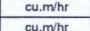 & $\begin{array}{l}\text { FLOW } \\
\text { FLOW }\end{array}$ \\
\hline & PERLND Soils AB & & PER & Oab & 8001 & na & nata & $n / a$ & $\mathrm{n} / \mathrm{a}$ & nia & n/a & nata & n/a & $\hat{i}$ & $x$ & $x$ & 0 & 0 & 0 & 0 & 0 & 0 & 100 & 0 & 100 & 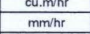 & SAB \\
\hline & LND Soils BC & Surtace & PER & $a b c$ & 8002 & & $n$ na & n/a & $n / a$ & nia & $n / a$ & n/a & n/a & $x$ & $\therefore$ & $x$ & 0 & 0 & 0 & 0 & 0 & 0 & 100 & 0 & 100 & $m m / h r$ & SBC \\
\hline & PERLND Soils CD & & $\begin{array}{l}\text { PER } \\
\text { PFA }\end{array}$ & ocd & 8003 & nia & nia & n/a & $\mathrm{n} / \mathrm{a}$ & n/a & n/a & n/a & n/a & $x$ & $x$ & $\therefore$ & 0 & 0 & 0 & 0 & 0 & 0 & 100 & 0 & 100 & $m m / h r$ & $S C D$ \\
\hline Special & $\begin{array}{l}\text { PERLND Soils AB } \\
\text { PER RDD Sols B }\end{array}$ & Subsurface & $\begin{array}{l}\text { PER } \\
\text { PER }\end{array}$ & $\frac{\text { aabx }}{0 \text { back }}$ & $\begin{array}{l}8501 \\
85020\end{array}$ & $\frac{n / a}{n}$ & \begin{tabular}{|l|l|}
$n / a$ \\
$n / a$
\end{tabular} & $n / a$ & $n / a$ & $\frac{n / a}{n / a}$ & $n / a$ & $\frac{n / a}{n / a}$ & $\frac{n / a}{n / a}$ & $\dot{x}$ & $x$ & $\frac{x}{x}$ & $\therefore$ & 0 & 0 & 0 & 0 & 0 & 100 & 0 & 100 & $\mathrm{~mm} / \mathrm{hr}$ & GWAB \\
\hline & $\begin{array}{l}\text { PERRNDD Sols } \\
\text { PERLND Sols CD }\end{array}$ & Subsurace & $\begin{array}{l}P E R \\
P E R\end{array}$ & $0 \mathrm{bcc}$ & $\begin{array}{l}8502 \\
8503\end{array}$ & $\frac{n}{n / a}$ & \begin{tabular}{|l|}
$n / a$ \\
$n / a$ \\
\end{tabular} & $\frac{n / a}{n / a}$ & $\frac{\mathrm{n} / \mathrm{a}}{\mathrm{n} / \mathrm{a}}$ & $\frac{n+a}{n / a}$ & $\frac{n / a}{n / a}$ & $\frac{n+a}{n / a}$ & $\frac{n / a}{N / a}$ & $\frac{x}{x}$ & $x$ & $x$ & $\therefore$ & $\frac{0}{0}$ & 0 & 0 & 0 & 0 & $\frac{100}{100}$ & $\div$ & $\frac{100}{100}$ & $m m / h r$ & $\frac{G W B C}{G G C D}$ \\
\hline$\infty$ & 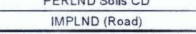 & Surface & IMP & 0 & 8004 & $\begin{array}{ll}n_{n} \\
n_{1 / 2}\end{array}$ & \begin{tabular}{|l|}
$n / a$ \\
\end{tabular} & 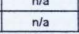 & $\frac{\mathrm{na}_{\mathrm{a}}}{\mathrm{na}}$ & $\frac{n a}{n / a}$ & $\frac{n}{n / a}$ & nia & $\frac{m_{2}}{n / 2}$ & n/a & $\frac{x}{n / a}$ & n/a & 0 & 100 & 50 & 0 & 0 & 0 & 0 & 100 & 0 & $\begin{array}{ll}\mathrm{mmmhr} \\
\mathrm{mm} / \mathrm{hr}\end{array}$ & ROAD \\
\hline & & & & & 213 & & & 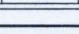 & & & 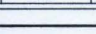 & = & & & & & & & & & & & & 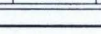 & & 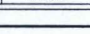 & = \\
\hline
\end{tabular}


Appendix C: Highland Creek Land Use \& Watershed Catchment Plan

(MAUNDER, 2004) 
EXISTING LAND USE BREAKDOWN (circa 1995)

Highland Creek Watershed within the City

\begin{tabular}{|c|c|c|c|c|c|c|c|c|c|c|c|}
\hline $\begin{array}{l}\text { Catchment ID / Area } \\
\text { Land Use Category }\end{array}$ & $\begin{array}{l}100 \\
\text { [ha] } \\
\end{array}$ & $\begin{array}{l}101 \\
\text { [ha] }\end{array}$ & $\begin{array}{c}102 \\
\text { [ha] }\end{array}$ & $\begin{array}{c}103 \\
{[\text { ha] }}\end{array}$ & \begin{tabular}{|c|}
104 \\
[ha]
\end{tabular} & $\begin{array}{c}105 \\
\text { [ha] }\end{array}$ & $\begin{array}{c}200 \\
\text { [hal } \\
\end{array}$ & $\begin{array}{c}201 \\
\text { [ha] }\end{array}$ & \begin{tabular}{|c|}
202 \\
[ha] \\
\end{tabular} & \begin{tabular}{|c|}
203 \\
{$[\mathrm{ha}]$}
\end{tabular} & $\begin{array}{r}204 \\
\text { [ha] }\end{array}$ \\
\hline RLD5ab & 69.0 & \begin{tabular}{|l|}
38.7 \\
\end{tabular} & 14.0 & 3.8 & 17.1 & $\begin{array}{l}0.0 \\
0.0\end{array}$ & 34.6 & $\begin{array}{l}0.0 \\
\end{array}$ & $\begin{array}{r}0.0 \\
\end{array}$ & $\begin{array}{l}0.0 \\
\end{array}$ & 0.0 \\
\hline RLDSbc & 6.1 & 14.5 & 20.6 & 3.3. & 17.9 & 0.0 & 24.6 & 0.0 & 0.0 & 36.4 & 16.1 \\
\hline RLDSed & 0.0 & 0.0 & 0.0 & 0.0 & 0.0 & 0.0 & 0.0 & 0.0 & 0.0 & 0.0 & 0.0 \\
\hline RLD8ab & & & & & & & & & & & \\
\hline RLD8be & & & & & & & & & & & 9.9 \\
\hline $\begin{array}{l}\text { RMD8ab } \\
\text { RMDSab }\end{array}$ & 86.7 & 22.5 & 25.0 & 19.8 & 28.4 & 0.0 & 114.4 & 0.0 & 0.0 & 0.0 & 0.0 \\
\hline RMDSbe & 21.1 & 26.9 & 56.6 & 8.0 & 40.4 & 2.3 & 63.0 & 0.0 & 0.0 & 91,3 & 22.5 \\
\hline RMD5cd & 0.0 & 0.0 & 0.0 & 0.0 & 0.0 & 0.0 & 0.0 & 0.0 & 0.0 & 0.0 & 0.0 \\
\hline RHD5ab & 17.4 & 3.8 & 0.0 & 3.8 & 0.0 & 0.0 & 10.0 & 0.0 & 0.0 & 0.0 & 0.0 \\
\hline RHD5be & 0.0 & 0.0 & 7.5 & 0.0 & 11.9 & 0.0 & 7.1 & 7.6 & 0.0 & 25.9 & 2.2 \\
\hline RHD5ed & 0.0 & 0.0 & 0.0 & 0.0 & 0.0 & 0.0 & 0.0 & 0.0 & 0.0 & 0.0 & 0.0 \\
\hline RHR2ab & 9.2 & 3.3 & 0.0 & 9.1 & 0.0 & 0.0 & 6.3 & 4.1 & 0.0 & 0.0 & 0.0 \\
\hline RHR2be & 4.6 & 19.5 & 13.6 & 3.3 & 5.2 & 0.0 & 0.0 & 6.1 & 0.0 & 19.3 & 1.7 \\
\hline RHR2ed & 0.0 & 0.0 & 0.0 & 0.0 & 0.0 & 0.0 & 0.0 & 0.0 & 0.0 & 0.0 & 0,0 \\
\hline CBBbc & 4.0 & 4.7 & 3.3 & 6.3 & 0.0 & 4.7 & 0.0 & 13.3 & 9.3 & 7.4 & 12,1 \\
\hline CSMbc & 6.7 & 11.0 & 12.8 & 22.5 & 25.1 & 0.0 & 10.0 & 8.2 & 4.3. & 6.8 & 7.3 \\
\hline EISab & 9.5 & 6,3 & 7.1 & 17.6 & 4.7 & 0.0 & 23.8 & 0.0 & 0.0 & 0.0 & 0.0 \\
\hline EISbc & 7.0 & 3.6 & 14.9 & 11.5 & 10.9 & 5.3 & 11.3 & 12.9 & 0.0 & 22.2 & 9.6 \\
\hline EISed & 0.0 & 0.0 & 0.0 & 0.0 & 0.0 & 0.0 & 0.0 & 0.0 & 0.0 & 0.0 & 0.0 \\
\hline ElUab & 0.0 & 0.0 & 0.0 & 0.0 & 0.0 & 0.0 & 0.0 & 0.0 & 0.0 & 0.0 & 0.0 \\
\hline Elubc & 0.0 & 0.0 & 0.0 & 0.0 & 0.0 & 0.0 & 0.0 & 0.0 & 0.0 & 0.0 & 0.0 \\
\hline OPLab & 27.8 & 19.7 & 15.1 & 30.5 & 6.4 & 0.0 & 57.6 & 3.3 & 0.6 & 0.0 & 0.0 \\
\hline OPLbc & 19.9 & 48.0 & 13.0 & 15.7 & 9.5 & 26.8 & 0.0 & 33.9 & 0.0 & 40.7 & 17.7 \\
\hline OPLed & 0.0 & 0.0 & 0.0 & 0.0 & 0.0 & 0.0 & 0.0 & 0.0 & 0.0 & 0.0 & 0.0 \\
\hline OVLab & 0.0 & 0.0 & 0.0 & 0.0 & 0.0 & 0.0 & 30.9 & 0.0 & 0.0 & 0.0 & 0.0 \\
\hline OVLbe & 9.8 & 0.01 & 0.0 & 0.0 & 0.0 & 0.0 & 23.8 & 0.0 & 0.0 & 0.0 & 0. \\
\hline THCab & 4.3 & 0.0 & 0.0 & 0.0 & 0.0 & 0.0 & 0.0 & 0.0 & 0.0 & 0.0 & 0.0 \\
\hline $\mathrm{rHCbc}$ & 0.0 & 0.0 & 0.0 & 0.0 & 0.0 & 10.0 & 0.0 & 3.1 & 2.6 & 34.4 & 19.1 \\
\hline THCed & 0.0 & 0.0 & 0.0 & 0.0 & 0.0 & 0.0 & 0.0 & 0.0 & 0.0 & 0.0 & 0.0 \\
\hline TRYbc & 0.0 & 0.0 & 0.0 & 0.01 & 0.0 & 0.0 & 0.0 & 0.0 & 0.0 & 0.0 & 0.0 \\
\hline TRYcd & 0.0 & 0.0 & 0.0 & 0.0 & 0.0 & 0.0 & 0.0 & 0.0 & 0,0 & 0.0 & 0.0 \\
\hline IPRab & 0.0 & 0.0 & 0.0 & 0.0 & 0.0 & 0.0 & 0.0 & 0.0 & 0.0 & 0.0 & 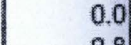 \\
\hline IPRbc & 0.0 & 11.2 & 0.0 & 0.0 & 0.0 & 7.4 & 0.0 & 0.0 & 0.0 & 0.0 & 9.8 \\
\hline IPRed & 0.0 & 0.0 & 0.0 & 0.0 & 0.0 & 0.0 & 0.0 & 0.0 & 0.0 & 0.0 & 0.0 \\
\hline IBBbe & 24 & 40.6 & 0.0 & 119.5 & 16.9 & 73.6 & 0.0 & 103.3 & 0.0 & 0.0 & 27.1 \\
\hline AGRab & 0.0 & 0.0 & 0.0 & 0.0 & 0.0 & 0.0 & 0.0 & 0.0 & 0.0 & 0.0 & 0.0 \\
\hline AGRbc & 0.0 & 0.0 & 0.0 & 0.0 & 0.0 & 0.0 & 0.0 & 0.0 & 0.0 & 0.0 & 0.0 \\
\hline Total & 305.4 & 274.2 & 203.5 & 274.8 & 194.3 & 130.3 & 417.4 & 196.0 & 16.8 & 284.3 & 154.2 \\
\hline Imper & 120.7 & 126.5 & 88.5 & 178.1 & 102.0 & 91.6 & 149.2 & 137.3 & 15.2 & 1322 & 91.5 \\
\hline Percent Impervious & $39.5 \%$ & $46.1 \%$ & $43.5 \%$ & $64.8 \%$ & $52.5 \%$ & $70.3 \%$ & $35.7 \%$ & $70.1 \%$ & $90.6 \%$ & $46.5 \%$ & $59.1 \%$ \\
\hline Flow Location & Total Area & Catchments & & & & & & & & & \\
\hline Dorset Park Interceptor & 1382.4 & $100-105$ & & & & & & & & & \\
\hline Bendale Branch & 2533.4 & $200-211$ & & & & & & & & & \\
\hline Markham Branch & 2124.3 & $300-306$ & & & & & & & & & \\
\hline Malvern Branch & 1411.1 & $400-404$ & & & & & & & & & \\
\hline Centennial Creek & 519.0 & $500-502$ & & & & & & & & & \\
\hline To RAP Gauge & 9473.5 & $100-404,60$ & $02,603,604$ & $7,605,606,60$ & $607,608,609$ & & & & & & \\
\hline To wsc Gauge & 9379.2 & $100-404,60$ & $02,604,605$, & $606,607,60$ & 08,603 & & & & & & \\
\hline Total & 10574.5 & $.100-609$ & & & & & & & & & \\
\hline Areas using "noth" preci & 1254.5 & $208,210,21$ & $11,305,30$ & 96,403 & $11.9 \%$ & & & & & & \\
\hline Areas using "south" prec & 9320.1 & & & & $88.1 \%$ & & & & & & \\
\hline
\end{tabular}




\begin{tabular}{|c|c|c|c|c|c|c|c|c|c|c|c|c|}
\hline & $\begin{array}{l}206 \\
\text { [ha] }\end{array}$ & ${ }^{207}[\mathrm{ha}]$ & $\begin{array}{l}208 \\
\text { [ha] }\end{array}$ & \begin{tabular}{|l|}
209 \\
[ha]
\end{tabular} & \begin{tabular}{|l}
210 \\
$\quad$ hal
\end{tabular} & $\begin{array}{ll}211 & \\
\text { [ha] }\end{array}$ & $\begin{array}{l}300 \\
\text { [ha] }\end{array}$ & $\begin{array}{r}301 \\
\text { [ha] }\end{array}$ & $\begin{array}{c}302 \\
\quad \text { ha] }\end{array}$ & $\begin{array}{l}303 \\
\text { [ha] }\end{array}$ & $\begin{array}{l}30.4 \\
\text { [ha] }\end{array}$ & $\begin{array}{l}305 \\
{[\mathrm{na}]}\end{array}$ \\
\hline 0.0 & 0.0 & 0.0 & 0.0 & 0.0 & 0.0 & 0.0 & 10.7 & 0.0 & 0.0 & 0.0 & 0.0 & 0.0 \\
\hline 38.7 & 3.6 & 15.6 & 11.5 & 1.5 & 3.6 & 6.8 & 0.0 & 29.2 & 66.7 & 16.8 & 19.9 & 11.8 \\
\hline 0.0 & 0.0 & 0.0 & 0.0 & 0.0 & 0.0 & 0.0 & 0.0 & 0.0 & 0.0 & 0.0 & 0.0 & 0.0 \\
\hline 2.1 & & & & & & & & & 2.4 & & & \\
\hline 0.0 & 0.0 & 0.0 & 0.0 & 0.0 & 0.0 & 0.0 & 40.8 & 0.0 & 0.0 & 0.0 & 0.0 & 0.0 \\
\hline 60.7 & 53.3 & 91.4 & 89.7 & 5.9 & 31.5 & 59.3 & 0.0 & 52.8 & 87.6 & 44.0 & 91.9 & 76.1 \\
\hline 0.0 & 0.0 & 0.0 & 0.0 & 0.0 & 0.0 & 0.0 & 0.0 & 8.1 & 0.0 & 0.0 & 0.0 & 0.0 \\
\hline 0.0 & 0.0 & 0.0 & 0.0 & 0.0 & 0.0 & 0.0 & 9.9 & 0.0 & 0.0 & 0.0 & 0.0 & 0.0 \\
\hline 19.1 & 26.3 & 59.5 & 59.1 & 13.5 & 29.2 & 55.0 & 0.0 & 20.3 & 17.9 & 28.0 & 43,4 & 24.5 \\
\hline 0.0 & 0.0 & 0.0 & 0.0 & 0.0 & 0.0 & 0.0 & 0.0 & 0.0 & 0.0 & 0.0 & 0.0 & 0.0 \\
\hline 0.0 & 0.0 & 0.0 & 0.0 & 0.0 & 0.0 & 0.0 & 0.0 & 0.0 & 0.0 & 0.0 & 0.0 & 0.0 \\
\hline 24.4 & 17.3 & 30.2 & $24 \times 3$ & 3.2 & 0.0 & 0.0 & 20.2 & 8.9 & 0.0 & 0.0 & 13.6 & 0.0 \\
\hline 0.0 & 0.0 & 0.0 & 0.0 & 0.0 & 0.0 & 0.0 & 0.0 & 0.0 & 0.0 & 0.0 & 0.0 & 0.0 \\
\hline 0.0 & 3.6 & 4.7 & 7.7 & 0.0 & 7.9 & 18.1 & 43.8 & 22.2 & 0.0 & 17.1 & 15.1 & 0.0 \\
\hline 19.7 & 5.3 & 14.0 & 0.0 & 0.0 & 0.0 & 0.0 & 10.7 & 22.9 & 7.4 & 3.4 & 0.0 & 1.5 \\
\hline 0.0 & 0.0 & 0.0 & 0.0 & 0.0 & 0.0 & 0.0 & 15.5 & 0.0 & 0.0 & 0.0 & 0.0 & 0.0 \\
\hline 10.6 & 26.1 & 27.9 & 37.7 & 8.1 & 17.5 & 7.3 & 15.0 & 18.5 & 31.5 & 13.4 & 32.4 & 7.4 \\
\hline 0.0 & 0.0 & 0.0 & 0.0 & 0.0 & 0.0 & 0.0 & 0.0 & 0.0 & 0.0 & 0.0 & 0.0 & 0.0 \\
\hline 0.0 & 0.0 & 0.0 & 0.0 & 0.0 & 0,0 & 0.0 & 0.0 & 0.0 & 0.0 & 0.0 & 0.0 & 0.0 \\
\hline 0.0 & 0.0 & 0.0 & 0.0 & 0.0 & 0.0 & 0.0 & 18.5 & 0.0 & 0.0 & 0.0 & 0.0 & 0.0 \\
\hline 0.0 & 0.0 & 0.0 & 0.0 & 0.0 & 0.0 & 0.0 & 24.5 & 0.0 & 0.0 & 0.0 & 0.0 & 0.0 \\
\hline 76.6 & 16.2 & 58.8 & 42.9 & 53.8 & 67.3 & 21.9 & 43.4 & 49.1 & 40.1 & 86.0 & 54.4 & 30.5 \\
\hline 0.0 & 0.0 & 0.0 & 0.0 & 0.0 & 0.0 & 0.0 & 0.0 & 7.8 & 0.0 & 0.0 & 0.0 & 0.0 \\
\hline 0.0 & 0.0 & 0.0 & 0.0 & 0.0 & 0.0 & 0.0 & 0.0 & 0.0 & 0.0 & 0.0 & 0.0 & 0.0 \\
\hline 0.0 & 0.0 & 0.0 & 0.0 & 0.0 & 0.0 & 0.0 & 18.9 & 0.0 & 0.0 & 0.0 & 0.0 & 0.0 \\
\hline 0.0 & 0.0 & 0.0 & 0.0 & 0.0 & 0.0 & 0.0 & 5.2 & 0.0 & 0.0 & 0.0 & 0.0 & 0.0 \\
\hline 0.0 & 0.0 & 0.0 & 0.0 & 0.0 & 0.0 & 0.0 & 64.0 & 14.8 & 0.0 & 0.0 & 0.0 & 0.0 \\
\hline 0.0 & 0.0 & 0.0 & 0.0 & 0.0 & 0.0 & 0.0 & 0.0 & 0.0 & 0.0 & 0.0 & 0.0 & 0.0 \\
\hline 0.0 & 0.0 & 0.0 & 0.0 & 0.0 & 0.0 & 0.0 & 0.0 & 6.7 & 0.0 & 0.0 & 69.9 & 0.0 \\
\hline 0.0 & 0.0 & 0.0 & 0.0 & 0.0 & 0.0 & 0.0 & 0.0 & 0.0 & 0.0 & 0.0 & 0.0 & 0.0 \\
\hline 0.0 & 0.0 & 0.0 & 0.0 & 0.0 & 0.0 & 0.0 & 11.2 & 0.0 & 0.0 & 0.0 & 0.0 & 0.0 \\
\hline 0.0 & 0.0 & 16.6 & 0.0 & 0.0 & 16.7 & 0.0 & 0.0 & 39.9 & 9.9 & 11.2 & 9.2 & 0.0 \\
\hline 0.0 & 0.0 & 0.0 & 0.0 & 0.0 & 0.0 & 0,0 & 0.0 & 8.5 & 0.0 & 0.0 & 0.0 & 0.0 \\
\hline 0.0 & 0.0 & 13,6 & 0.0 & 0.0 & 24.8 & 2.4 & 77.3 & 59.9 & 45.0 & 46.5 & 18.0 & 0.0 \\
\hline 0.0 & 0.0 & 0.0 & 0.0 & 0.0 & 0.0 & 0.0 & 0.0 & 0.0 & 0.0 & 0.0 & 0.0 & 0.0 \\
\hline 0.0 & 0.0 & 0.0 & 0.0 & 0.0 & 0.0 & 0.0 & 0.0 & 0.0 & 0.0 & 13.7 & 0.0 & 0.0 \\
\hline 251.9 & 151.8 & 332.3 & 272.9 & 85.9 & 198.4 & 170.9 & 429,6 & 369.5 & 308.5 & 280.2 & 367.7 & 151.9 \\
\hline 97.6 & 72.2 & 163.2 & 122.7 & & 92.3 & 92.0 & 245.9 & 222.1 & 147.3 & 130.4 & 190.5 & 64.4 \\
\hline $38.7 \%$ & $47.6 \%$ & $49.1 \%$ & $45.0 \%$ & $25.3 \%$ & $46.5 \%$ & $53.8 \%$ & $57.2 \%$ & $60.1 \%$ & $47.7 \%$ & $46.5 \%$ & $51.8 \%$ & $42,4 \%$ \\
\hline
\end{tabular}




\begin{tabular}{|c|c|c|c|c|c|c|c|c|c|c|c|c|}
\hline $\begin{array}{c}306 \\
\quad[\text { ha] } \\
\end{array}$ & ${ }^{400}$ (ha) & $\begin{array}{c}40 t \\
\text { [ha] }\end{array}$ & ${ }^{402}$ [ha] & \begin{tabular}{|l|}
403 \\
[ha]
\end{tabular} & $\begin{array}{c}404 \\
\text { (ha) }\end{array}$ & \begin{tabular}{|l|l}
500 \\
{$[\mathrm{ha}]$}
\end{tabular} & [ha] & $\begin{array}{r}502 \\
{[h a]}\end{array}$ & $\begin{array}{c}600 \\
{[\text { hal }]} \\
\end{array}$ & \begin{tabular}{|c|}
601 \\
[hat
\end{tabular} & $\begin{array}{c}602 \\
\text { [ha] }\end{array}$ & $\begin{array}{c}603 \\
\text { [na] }\end{array}$ \\
\hline 0.0 & 0.0 & 0,0 & 0.0 & 0.0 & 0.0 & 0.0 & 27.3 & 27.7 & 4.3 & 0.9 & 20.2 & 27,0 \\
\hline 15.8 & 64.0 & 24.5 & 7.9 & 4.4 & 0.0 & 0.0 & 39.5 & 17.1 & 2.2 & 20.5 & 0.0 & 9,3 \\
\hline 0.0 & 0.0 & 0.0 & 0.0 & 0.0 & 0.0 & 0.0 & 0.0 & 0.0 & 0.0 & $\begin{array}{r}0.0 \\
0\end{array}$ & 0.0 & 0.0 \\
\hline & & & & & & & 31,2 & 34.5 & & 59.0 & 17.3 & 30.0 \\
\hline & & & & & & & 31.2 & 17.3 & & 29.6 & & 10.3 \\
\hline 0.0 & 0.0 & 0.0 & 0.0 & 0.0 & 0.0 & 0.0 & 32.2 & 9.8 & 0.0 & 8.5 & 15.1 & 32.4 \\
\hline 101.8 & 38.2 & 29.5 & 0.0 & 63.3 & 16.6 & 16.0 & 50.3 & 3.1 & 0.0 & 22.3 & 0.0 & 7.9 \\
\hline 0.0 & 0.0 & 0.0 & 0.0 & 0.0 & 0.0 & 0.0 & 0.0 & 0.0 & 0.0 & 0.0 & 0.0 & 0.0 \\
\hline 0.0 & 0.0 & 0.0 & 0.0 & 0.0 & 0.0 & 0.0 & 12.3 & 13.1 & 0.0 & 17.6 & 10.9 & 25.8 \\
\hline 32.5 & 25.5 & 18.5 & 0.0 & 60.1 & 0.0 & 4.6 & 11.3 & 2.6 & 0.0 & 0.0 & 0.0 & 5.6 \\
\hline 0.0 & 0.0 & 0.0 & 0.0 & 0.0 & 0.0 & 0.0 & 0.0 & 0.0 & 0.0 & 0.0 & 0.01 & 0.0 \\
\hline 0.0 & 0.0 & 0.0 & 0.0 & 0.0 & 0.0 & 0.0 & 0.0 & 0.0 & 0.0 & 10.4 & 8.11 & 0.0 \\
\hline 0.0 & 13.3 & 3.6 & 0.0 & 15.1 & 0.0 & 0.0 & 0.0 & 0.0 & 0.0 & 0.0 & 0.0 & 0.0 \\
\hline 0.0 & 0.0 & 0.0 & 0.0 & 0.0 & 0.0 & 0.0 & 0.0 & 0,0 & 0.0 & 0.0 & 0.0 & 00 \\
\hline 0.0 & 6.1 & 0.0 & 6.8 & 5.8 & 7.7 & 0.0 & 0.0 & 4.0 & 0.0 & 5.1 & 16.9 & 0.0 \\
\hline 0.0 & 7.0 & 11.3 & 0.0 & 0.0 & 4.3 & 0.0 & 0.0 & 2.4 & 0.0 & 5.7 & 9.1 & 11.5 \\
\hline 0.0 & 0.0 & 0.0 & 0.0 & 0.0 & 0.0 & 0.0 & 5.8 & 5.4 & 0.0 & 8.6 & 18.7 & 20.2 \\
\hline 8.7 & 15.6 & 26.0 & 0.0 & 18.0 & 8.6 & 0.0 & 12.9 & 0.0 & 0.0 & 13.7 & 0.0 & 0.0 \\
\hline 0.0 & 0.0 & 0.0 & 0.0 & 0.0 & 0.0 & 0.0 & 0.0 & 0.0 & 0.0 & 0.0 & 0.0 & 0.0 \\
\hline 0.0 & 0.0 & 0.0 & 0.0 & 0.0 & 0.0 & 0.0 & 0.0 & 0.0 & 0.0 & 0.0 & 34.8 & 7.0 \\
\hline 0.0 & 4.9 & 0.0 & 0.0 & 0.0 & 0.0 & 0.0 & 0.0 & 0.0 & 0.0 & 0.0 & 28 & 00 \\
\hline 0.0 & 0.0 & 0.0 & 0.0 & 0.0 & 0.0 & 0.0 & 17.5 & 14.3 & 2.1 & 22.6 & 12.5 & 78.7 \\
\hline 58.1 & 26.9 & 55.8 & 64.9 & 70.9 & 68.9 & 7.7 & 12.3 & 9.0 & 7.8 & 18.5 & 0.0 & 5.3 \\
\hline 0.0 & 0.0 & 0.0 & 0.0 & 0.0 & 0.0 & 0.0 & 0.0 & 0.0 & 0.0 & 0.0 & 0.0 & 0.0 \\
\hline 0.0 & 0.0 & 0.0 & 0.0 & 0.0 & 0.0 & 0.0 & 5.2 & 0.0 & 32.2 & 3.3 & 27.2 & 0.0 \\
\hline 0.0 & 18.5 & 0.0 & 0.0 & 0.0 & 0.0 & 0.7 & 17.5 & 0.0 & 42.9 & 22.6 & 7.9 & 9.8 \\
\hline 0.0 & 0.0 & 0.0 & 0.0 & 0.0 & 0.0 & 0.0 & 0.0 & 12.4 & 0.0 & 0.0 & 0.0 & 0.0 \\
\hline 0.0 & 36.8 & 0.0 & 0.0 & 0.0 & 0.0 & 0.0 & 0.0 & 0.0 & 0.0 & 0.0 & 0.0 & 0.0 \\
\hline 0.0 & 0.0 & 0.0 & 0.0 & 0.0 & 0.0 & 0.0 & 0.0 & 0.0 & 0.0 & 0.0 & 0.0 & 0.0 \\
\hline 0.0 & 0.0 & 6.9 & 73.7 & 0.0 & 0.0 & 0.0 & 0.0 & 0.0 & 0.0 & 0.0 & 0.0 & 0.0 \\
\hline 0.0 & 0.0 & 0.0 & 0.0 & 0.0 & 0.0 & 0.0 & 0.0 & 0.0 & 0.0 & 0.0 & 0.0 & 0.0 \\
\hline 0.0 & 0.0 & 0.0 & 0.0 & 0.0 & 0.0 & 0.0 & 0.0 & 0.0 & 0.0 & 4.2 & 0.0 & 0.0 \\
\hline 0.0 & 7.2 & 0.0 & 0.0 & 0.0 & 4.9 & 0.0 & 0.0 & 0.0 & 0.0 & 4.2 & 0.0 & 0.0 \\
\hline 0.0 & 0.0 & 0.0 & 0.0 & 0.0 & 0.0 & 0.0 & 0.0 & 0.0 & 0.0 & 0.0 & 0.0 & 0.0 \\
\hline 0.0 & 25.5 & 122.4 & 135.7 & 5.8 & 167.7 & 11.0 & 0.0 & 0.0 & 6.2 & 15.5 & 0.0 & 0.2 \\
\hline 0.0 & 0.0 & 0.0 & 0.0 & 0.0 & 0.0 & 0.0 & 0.0 & 0.0 & 0.0 & 0.0 & 0.0 & 0.0 \\
\hline 0.0 & 0.0 & 0.0 & 4.7 & 0.0 & 7.1 & 0.0 & 0.0 & 0.0 & 0.0 & 0.0 & 0.0 & 0.9 \\
\hline 217.0 & 289.7 & 298.4 & 293.7 & 243.5 & 285.7 & 39.9 & 306.4 & 172.7 & 97.6 & 297.8 & 201.4 & 280.9 \\
\hline 85.4 & 139.4 & 179.5 & 193.3 & 103.6 & 1895 & 22.0 & 111.2 & 68.1 & 10.9 & 114.8 & 75.7 & 94.3 \\
\hline $39.4 \%$ & $48.1 \%$ & $60.2 \%$ & $65.8 \%$ & $42.6 \%$ & $66.3 \%$ & $55.0 \%$ & $36.3 \%$ & $39.4 \%$ & $11.2 \%$ & $38.5 \%$ & $37.6 \%$ & $33.6 \%$ \\
\hline
\end{tabular}




\begin{tabular}{|c|c|c|c|c|c|c|c|c|c|c|c|}
\hline [ha] & $\begin{array}{l}605 \\
\text { [ha] } \\
\end{array}$ & $\begin{array}{c}606 \\
\text { Tha] }\end{array}$ & {$\left[\begin{array}{l}607 \\
\text { [na] }\end{array}\right.$} & $\begin{array}{l}608 \\
\text { Thal }\end{array}$ & $\begin{array}{c}609 \\
\text { [ha] }\end{array}$ & \begin{tabular}{|l|} 
Total \\
Area
\end{tabular} & $\begin{array}{l}\text { Modelled } \\
\text { Percent Imp. }\end{array}$ & $\begin{array}{l}\text { Impervious } \\
\text { Area }\end{array}$ & $\begin{array}{l}\text { Landuse } \\
\text { Landuse }\end{array}$ & $\begin{array}{l}\text { eakdown } \\
\text { |Total Area }\end{array}$ & Percentage \\
\hline 0.0 & 0.0 & 1.4 & 16.2 & 39.6 & 90.7 & 443.4 & $30 \%$ & 133.0 & RLD & 1300.3 & $12.3 \%$ \\
\hline 13.0 & 31.5 & 6.0 & 20.0 & 0.0 & 0.0 & 641.1 & $30 \%$ & 192.3 & RMD & 2400.6 & $22.7 \%$ \\
\hline 0.0 & 0.0 & 0.0 & 0.0 & 0.0 & 0.0 & 0.0 & $30 \%$ & 0.0 & $\mathrm{RHO}$ & 818.1 & $7.7 \%$ \\
\hline & & & & 9.0 & 20.4 & 201.4 & $30 \%$ & 60.4 & RHR & 384.0 & $3.6 \%$ \\
\hline & & & & & & 14.4 & $30 \%$ & 4.3 & CEB & 263.7 & $2.5 \%$ \\
\hline & & & & & & 88.4 & $50 \%$ & 4.4 .2 & CSM & 329.1 & $3.1 \%$ \\
\hline 6.7 & 0.0 & 4.0 & 111.2 & 64.7 & 55.1 & 677.3 & $50 \%$ & 338.7 & EIS & 727.3 & $6.9 \%$ \\
\hline 19.4 & 65.4 & 8.0 & 96.5 & 5.2 & 7.0 & 1626.8 & $50 \%$ & 813.4 & EIU & 119.8 & $1.1 \%$ \\
\hline 0.0 & 0.0 & 0.0 & 0.0 & 0.0 & 0.0 & 8.1 & $50 \%$ & 4.1 & OPL & 1890.0 & $17.9 \%$ \\
\hline 7.7 & 0.0 & 1.9 & 9.0 & 10.8 & 9.0 & 163.2 & $65 \%$ & 106.1 & OVL. & 572.3 & $5.4 \%$ \\
\hline 15.8 & 12.5 & 0.0 & 7.9 & 0.0 & 0.0 & 655.0 & $65 \%$ & 425.7 & THC & 253.9 & $2.4 \%$ \\
\hline 0.0 & 0.0 & 0.0 & 0.0 & 0.0 & 0.0 & 0.0 & $65 \%$ & 0.0 & TRY & 157.1 & $1.5 \%$ \\
\hline 0.0 & 0.0 & 2.8 & 7.2 & 26.2 & 24.2 & 110.7 & $50 \%$ & 55.3 & IPR & 172.0 & $1.6 \%$ \\
\hline 14.1 & 0.0 & 0.0 & 11,7 & 0.0 & 0.0 & 273.3 & $50 \%$ & 136.6 & 18B & 1160.8 & $11.0 \%$ \\
\hline 0.0 & 0.0 & 0.0 & 0.0 & 0.0 & 0.0 & 0.0 & $50 \%$ & 0.0 & AGP & 25.6 & $0.2 \%$ \\
\hline 0.0 & 0.0 & 0.0 & 0.0 & 0.0 & 6.2 & 263.7 & $98 \%$ & 258.4 & & & \\
\hline 9.9 & 0.0 & 1.0 & 19.6 & 25.8 & 21.9 & 329.1 & $98 \%$ & 322.5 & Total & 10574.5 & \\
\hline 16.2 & 0.0 & 0.0 & 15.1 & 21.7 & 15.2 & 211.3 & $32 \%$ & 67.6 & & & \\
\hline 0.0 & 28.6 & $\cdot 1.4$ & 12.1 & $7 \times 9$ & 0.0 & 516.0 & $32 \%$ & 165.1 & & & \\
\hline 0.0 & 0.0 & 0.0 & 0.0 & 0.0 & 0.0 & 0.0 & $32 \%$ & 0.0 & & & \\
\hline 25.7 & 0.0 & 0.0 & 0.0 & 0.0 & 0.0 & 67.6 & $32 \%$ & 21.6 & & & \\
\hline 26.0 & 0.0 & 0.0 & 0.0 & 0.0 & 0.0 & 52.3 & $32 \%$ & 16.7 & & & \\
\hline 38.4 & 0.0 & 3.2 & 29.4 & 92.0 & 28.1 & 524.2 & $10 \%$ & 52.4 & & & \\
\hline 29.6 & 35.0 & 0.0 & 0.0 & 21.3 & 0.0 & 1358.1 & $10 \%$ & 135.8 & & & \\
\hline 0.0 & 0.0 & 0.0 & 0.0 & 0.0 & 0.0 & 7.8 & $10 \%$ & 0.8 & & & \\
\hline 0.0 & 0.0 & 16.6 & 0.0 & 33.6 & 0.0 & 154.1 & $3 \%$ & 4.6 & & & \\
\hline 86.6 & 89.7 & 29.1 & 21.1 & 16.1 & 3.4 & 418.3 & $3^{\circ} \%$ & 12.5 & & & \\
\hline 30.3 & 0.0 & 0.0 & 0.0 & 0.0 & 0.0 & 52.1 & $70 \%$ & 36.5 & & & \\
\hline 12.7 & 4.3 & 0.0 & 0.0 & 0.0 & 0.0 & 201.8 & $70 \%$ & 141.2 & & & \\
\hline 0.0 & 0.0 & 0.0 & 0.0 & 0.0 & 0.0 & 0.0 & $70 \%$ & 0.0 & & & \\
\hline 0.0 & 0.0 & 0.0 & 0.0 & 0.0 & 0.0 & 157.1 & $70 \%$ & 110.0 & & & \\
\hline 0.0 & 0.0 & 0.0 & 0.0 & 0.0 & 0.0 & 0.0 & $70 \%$ & 0.0 & & & \\
\hline 0.0 & 0.0 & 0.0 & 0.0 & 0.0 & 0.0 & 15.3 & $80 \%$ & 12,3 & & & \\
\hline 0.0 & 0.0 & 0.0 & 0.0 & 0.0 & 0.0 & 148.2 & $80 \%$ & 118.5 & & & \\
\hline 0.0 & 0.0 & 0.0 & 0.0 & 0.0 & 0.0 & 8.5 & $80 \%$ & 6.8 & & & \\
\hline 0.0 & 0.0 & 0.0 & 0.0 & 0.0 & 0.0 & 1160.8 & $93 \%$ & 1079.5 & & & \\
\hline 0.0 & 0.0 & 0.0 & 0.0 & 0.0 & 0.0 & 0.0 & $0 \%$ & 0.0 & & & \\
\hline 352.0 & 267.0 & 75.3 & 377.1 & 373.9 & 281.2 & $\begin{array}{r}25.6 \\
10574.5\end{array}$ & $\begin{array}{r}0 \% \\
\text { Weighted } \% \text { im } \\
46.1 \% \mid\end{array}$ & 4877.1 & & & \\
\hline 352.0 & 267,0 & & & ה780 & & 100.14 .00 & & & & & \\
\hline $\begin{array}{r}110.2 \\
31.3 \%\end{array}$ & $\begin{array}{r}68.6 \\
25.7 \%\end{array}$ & $\begin{array}{r}13.9 \\
18.5 \%\end{array}$ & $\begin{array}{r}166.7 \\
44.2 \%\end{array}$ & $\begin{array}{r}117.2 \\
31.4 \%\end{array}$ & $\begin{array}{r}117.7 \\
41.8 \%\end{array}$ & & & & & & \\
\hline
\end{tabular}




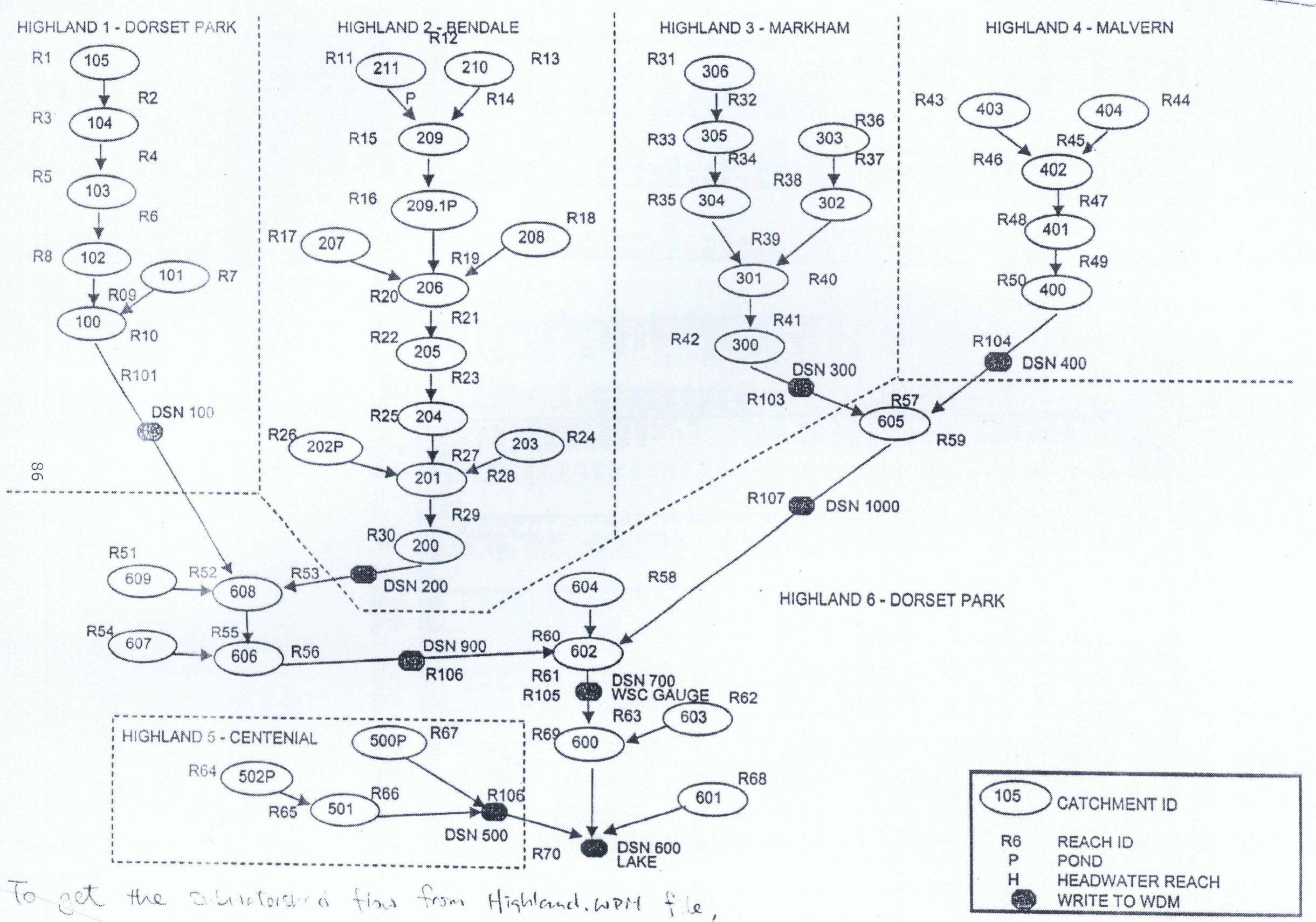

please reter the best mumber 


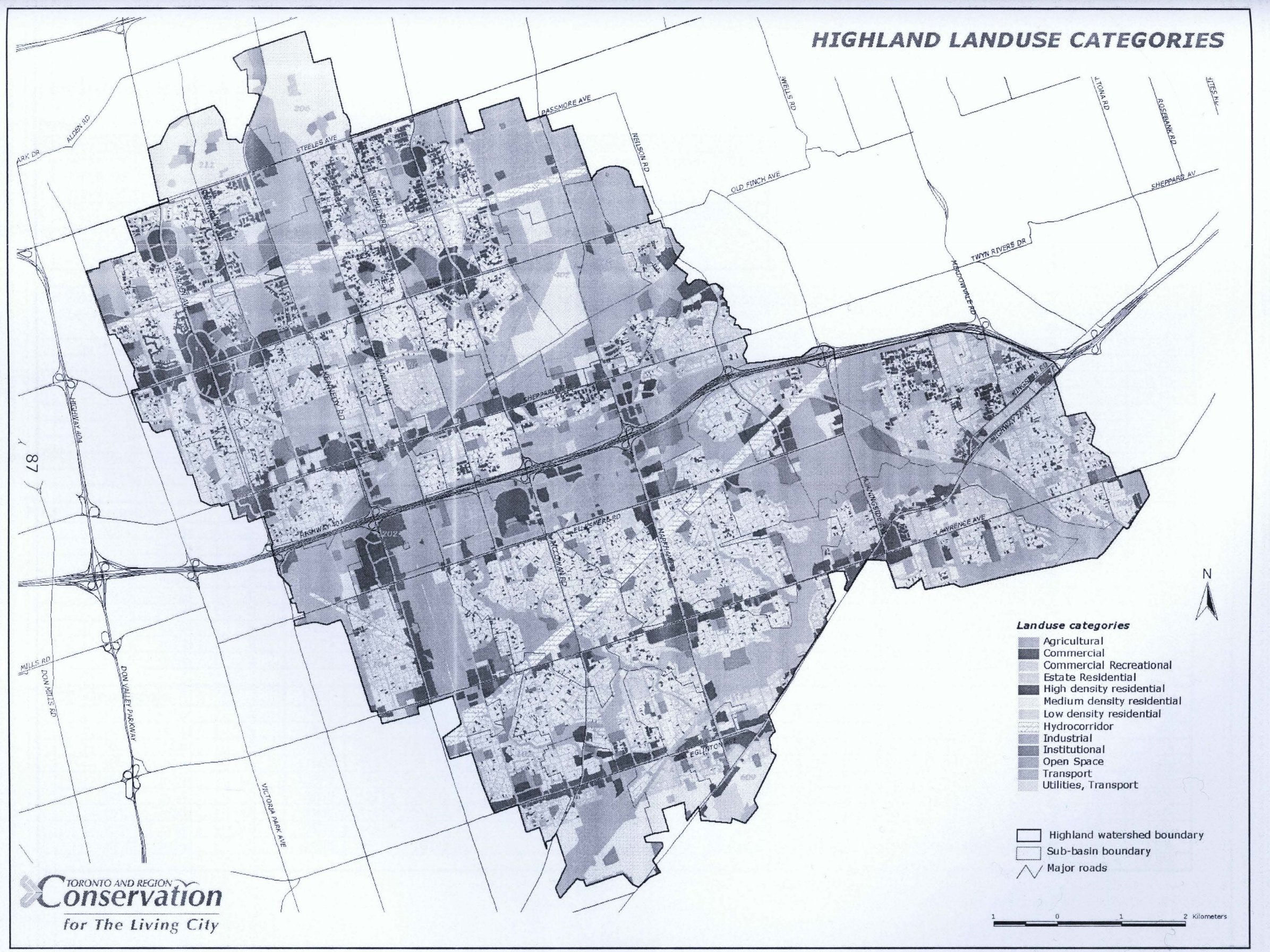

Figure A.2 Existing Landuses 
Appendix D: Calibration and Runoff Tables Using the Analytical Model 


\section{Low Density Residential}

Data

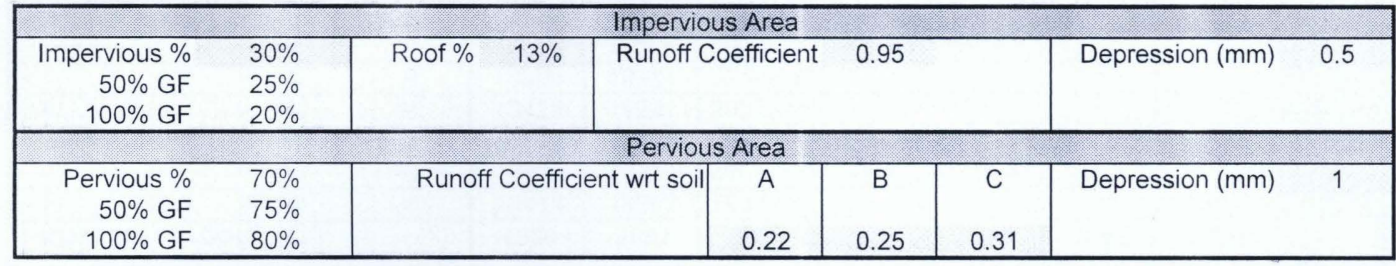

\begin{tabular}{|c|c|c|}
\hline \multicolumn{2}{|c|}{ No Green Roofs } & \multirow[b]{2}{*}{ Soil Type } \\
\hline Scenario & Constituent & \\
\hline 1001 & $\mathrm{~m} 3 / \mathrm{yr}$ & A \\
\hline 1002 & $\mathrm{~m} 3 / \mathrm{yr}$ & B \\
\hline 1003 & $\mathrm{~m} 3 / \mathrm{yr}$ & C \\
\hline 1004 & $\mathrm{~m} 3 / \mathrm{yr}$ & A \\
\hline 1005 & $\mathrm{~m} 3 / \mathrm{yr}$ & $B$ \\
\hline 1006 & $\mathrm{~m} 3 / \mathrm{yr}$ & $\mathrm{C}$ \\
\hline 1013 & $\mathrm{~m} 3 / \mathrm{yr}$ & A \\
\hline 1014 & $\mathrm{~m} 3 / \mathrm{yr}$ & $\mathrm{B}$ \\
\hline 1015 & $\mathrm{~m} 3 / \mathrm{yr}$ & C \\
\hline \multicolumn{3}{|c|}{$50 \%$ Greenroofs } \\
\hline 1001 & $\mathrm{~m} 3 / \mathrm{yr}$ & A \\
\hline 1002 & $\mathrm{~m} 3 / \mathrm{yr}$ & $B$ \\
\hline 1003 & $\mathrm{~m} 3 / \mathrm{yr}$ & $\mathrm{C}$ \\
\hline 1004 & $\mathrm{~m} 3 / \mathrm{yr}$ & A \\
\hline 1005 & $\mathrm{~m} 3 / \mathrm{yr}$ & $B$ \\
\hline 1006 & $\mathrm{~m} 3 / \mathrm{yr}$ & C \\
\hline 1013 & $\mathrm{~m} 3 / \mathrm{yr}$ & A \\
\hline 1014 & $\mathrm{~m} 3 / \mathrm{yr}$ & B \\
\hline 1015 & $\mathrm{~m} 3 / \mathrm{yr}$ & C \\
\hline
\end{tabular}

\begin{tabular}{|r|c|c|}
\hline $\mathbf{1 0 0 \%}$ Greenroofs \\
\hline 1001 & $\mathrm{~m} 3 / \mathrm{yr}$ & A \\
\hline 1002 & $\mathrm{~m} 3 / \mathrm{yr}$ & B \\
\hline 1003 & $\mathrm{~m} 3 / \mathrm{yr}$ & $\mathrm{C}$ \\
\hline 1004 & $\mathrm{~m} 3 / \mathrm{yr}$ & A \\
\hline 1005 & $\mathrm{~m} 3 / \mathrm{yr}$ & B \\
\hline 1006 & $\mathrm{~m} 3 / \mathrm{yr}$ & $\mathrm{C}$ \\
\hline 1013 & $\mathrm{~m} 3 / \mathrm{yr}$ & A \\
\hline 1014 & $\mathrm{~m} 3 / \mathrm{yr}$ & B \\
\hline 1015 & $\mathrm{~m} 3 / \mathrm{yr}$ & $\mathrm{C}$ \\
\hline
\end{tabular}

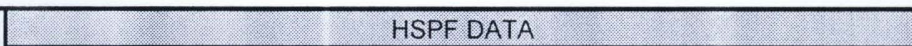

\begin{tabular}{|c|c|c|c|c|c|c|c|}
\hline 1990 & 1991 & 1992 & 1993 & 1994 & 1995 & 1996 & Average \\
\hline 11980 & 11833 & 16255.3 & 15274 & 12722 & 15968 & 19755 & 14826.8 \\
\hline 12570 & 11843 & 17625.3 & 15772 & 13952 & 16008 & 20898 & 15524 \\
\hline 13880 & 12174 & 21075.3 & 18423 & 16663 & 17308 & 24086 & 17658.5 \\
\hline 11980 & 11833 & 16255.3 & 15274 & 12722 & 15968 & 19755 & 14826.8 \\
\hline 12570 & 11843 & 17625.3 & 15772 & 13952 & 16008 & 20898 & 15524 \\
\hline 13880 & 12174 & 21075.3 & 18423 & 16663 & 17308 & 24086 & 17658.5 \\
\hline 11980 & 11833 & 16255.3 & 15274 & 12722 & 15968 & 19755 & 14826.8 \\
\hline 12570 & 11843 & 17625.3 & 15772 & 13952 & 16008 & 20898 & 15524 \\
13760 & 12144 & 20735.3 & 1893 & 16232 & 17078 & 23635 & 17382.5 \\
\hline
\end{tabular}
\begin{tabular}{|l|l|l|l|l|l|l|l|}
\hline & 17625.3 & 15772 & 13952 & 16008 & 20898 & 15524 \\
\hline
\end{tabular}

\begin{tabular}{|l|l|l|l|l|l|l|}
\hline \multicolumn{10}{|c|}{1990} & 1991 & 1992 & 1993 & 1994 & 1995 & 1996
\end{tabular}
\begin{tabular}{|l|l|l|l|l|l|l|l|}
13760 & 12144 & 20735.3 & 18093 & 16232 & 17078 & 23635 & 17382.5 \\
\hline
\end{tabular}

\begin{tabular}{|l|l|l|l|l|l|l|}
\hline \multicolumn{1}{|c|}{$\mid$} & 1990 \\
\hline 1990 & 1991 & 1992 & 1993 & 1994 & 1995 & 1996
\end{tabular}

\begin{tabular}{|c|c|c|c|c|c|c|c|}
\hline 1990 & 1991 & 1992 & 1993 & 1994 & 1995 & 1996 & \\
\hline 11980 & 11478 & 16185.3 & - & - & - & - & 13214.4 \\
\hline 12570 & 11491 & 17535.3 & - & - & - & - & 13865.4 \\
\hline 13880 & 12204 & 21045.3 & - & - & - & - & 15709.8 \\
\hline 11980 & 11478 & 16185.3 & - & - & - & - & 13214.4 \\
\hline 12570 & 11491 & 17535.3 & - & - & - & - & 13865.4 \\
\hline 13880 & 12204 & 21045.3 & - & - & - & - & 15709.8 \\
\hline 11980 & 11833 & 16255.3 & - & - & - & - & 13356.1 \\
\hline 12570 & 11843 & 17625.3 & - & - & - & - & 14012.8 \\
\hline 13760 & 12144 & 20735.3 & - & - & - & - & 15546.4 \\
\hline
\end{tabular}

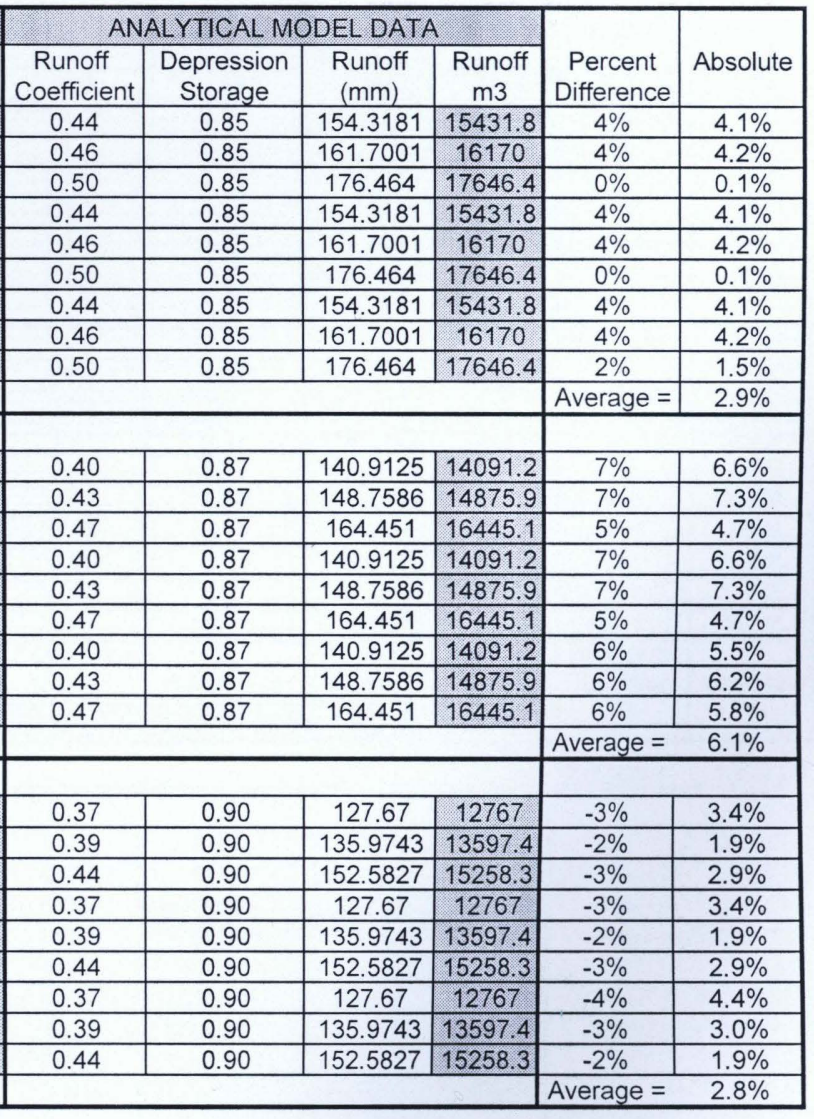

$=$ User Input

Comparison Data
= Calibrating User Input

\begin{tabular}{|c|c|c|c|c|c|c|c|c|c|c|c|c|c|}
\hline & & & & & & & & & & & & & \\
\hline 11980 & & & & & & & & & & & & & \\
\hline 11980 & 11478 & 16185.3 & - & - & - & - & 13214.4 & 0.37 & 0.90 & 127.67 & 12767 & $-3 \%$ & $3.4 \%$ \\
\hline 12570 & 11491 & 17535.3 & - & - & - & - & 13865.4 & 0.39 & 0.90 & 135.9743 & 13597.4 & $-2 \%$ & $1.9 \%$ \\
\hline 13880 & 12204 & 21045.3 & - & - & - & - & 15709.8 & 0.44 & 0.90 & 152.5827 & 15258.3 & $-3 \%$ & $2.9 \%$ \\
\hline 11980 & 11478 & 16185.3 & - & - & - & - & 13214.4 & 0.37 & 0.90 & 127.67 & 12767 & $-3 \%$ & $3.4 \%$ \\
\hline 12570 & 11491 & 17535.3 & - & - & - & - & 13865.4 & 0.39 & 0.90 & 135.9743 & 13597.4 & $-2 \%$ & $1.9 \%$ \\
\hline 13880 & 12204 & 21045.3 & - & - & - & - & 15709.8 & 0.44 & 0.90 & 152.5827 & 15258.3 & $-3 \%$ & $2.9 \%$ \\
\hline 11980 & 11833 & 16255.3 & - & - & $\begin{array}{ll}- \\
-\end{array}$ & - & 13356.1 & 0.37 & 0.90 & 127.67 & 12767 & $-4 \%$ & $4.4 \%$ \\
\hline 12570 & 11843 & 17625.3 & - & - & - & - & 14012.8 & 0.39 & 0.90 & 135.9743 & 13597.4 & $-3 \%$ & $3.0 \%$ \\
\hline 13760 & 12144 & 20735.3 & - & - & - & - & 15546.4 & 0.44 & 0.90 & 152.5827 & 15258.3 & $-2 \%$ & $1.9 \%$ \\
\hline & & & & & & & & & & & & \begin{tabular}{|l|} 
Average \\
\end{tabular} & $2.8 \%$ \\
\hline
\end{tabular}




\section{Medium Density Residential}

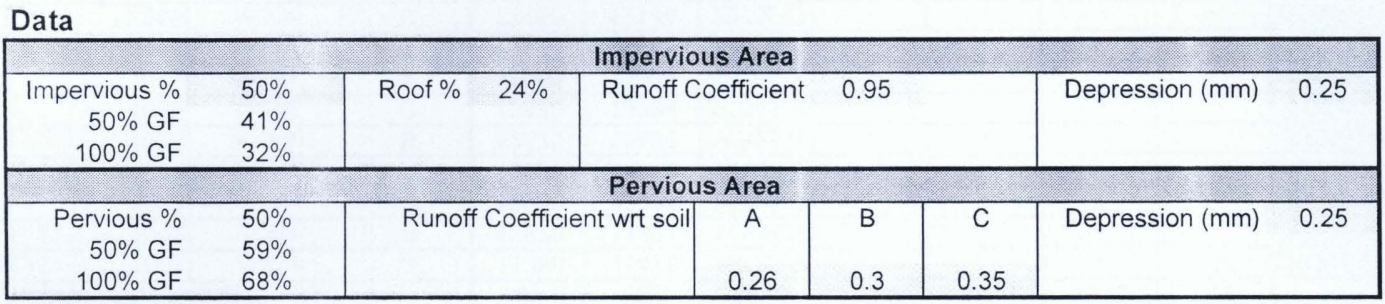

$=$ User Input

= Calibrating User Input

Comparison Data

$\bullet$

\begin{tabular}{|c|c|c|c|c|c|c|c|c|c|c|c|c|c|c|c|c|}
\hline & \multirow[b]{2}{*}{ Soil Type } & \multicolumn{8}{|c|}{ HSPF DATA } & \multicolumn{4}{|c|}{ ANALYTICAL MODEL DATA } & \multirow[b]{2}{*}{$\begin{array}{c}\text { Percent } \\
\text { Difference }\end{array}$} & \multirow[b]{2}{*}{ Absolute } \\
\hline $\begin{array}{l}\text { No Green Roofs } \\
\text { Scenario Constituent }\end{array}$ & Constituent & & 1990 & 1991 & 1992 & 1993 & 1994 & 1995 & 1996 & Average & $\begin{array}{c}\text { Runoff } \\
\text { Coefficient }\end{array}$ & Depression & \begin{tabular}{c|} 
Runoff \\
(mm)
\end{tabular} & $\begin{array}{c}\text { Runoff } \\
\text { m3 }\end{array}$ & & \\
\hline 1101 & $\mathrm{~m} 3 / \mathrm{yr}$ & A & 19474 & 19251 & 26299.4 & 24815 & 20446 & 25952 & 31820 & 24008.2 & 0.61 & 0.25 & 248.5752 & 24857.52 & $4 \%$ & $3.5 \%$ \\
\hline 1102 & $\mathrm{~m} 3 / \mathrm{yr}$ & B & 19904 & 19261 & 27349.4 & 25255 & 21426 & 25992 & 32730 & 24559.6 & 0.63 & 0.25 & 256.7925 & 25679.25 & $5 \%$ & $4.6 \%$ \\
\hline 1103 & $\mathrm{~m} 3 / \mathrm{yr}$ & $\mathrm{C}$ & 20914 & 19581 & 30019.4 & 27325 & 23516 & 27112 & 35250 & 26245.3 & 0.65 & 0.25 & 267.0642 & 26706.42 & $2 \%$ & $1.8 \%$ \\
\hline 1104 & $\mathrm{~m} 3 / \mathrm{yr}$ & A & 19474 & 19251 & 26299.4 & 24815 & 20446 & 25952 & 31820 & 24008.2 & 0.61 & 0.25 & 248.5752 & 24857.52 & $4 \%$ & $3.5 \%$ \\
\hline 1105 & $\mathrm{~m} 3 / \mathrm{yr}$ & B & 19904 & 19261 & 27349.4 & 25255 & 21426 & 25992 & 32730 & 24559.6 & 0.63 & 0.25 & 256.7925 & 25679.25 & $5 \%$ & $4.6 \%$ \\
\hline 1106 & $\mathrm{~m} 3 / \mathrm{yr}$ & $\mathrm{C}$ & 20914 & 19581 & 30019.4 & 27325 & 23516 & 27112 & 35250 & 26245.3 & 0.65 & 0.25 & 267.0642 & 26706.42 & $2 \%$ & $1.8 \%$ \\
\hline 1113 & $\mathrm{~m} 3 / \mathrm{yr}$ & A & 19474 & 19251 & 26299.4 & 24815 & 20446 & 25952 & 31820 & 24008.2 & 0.61 & 0.25 & 248.5752 & 24857.52 & $4 \%$ & $3.5 \%$ \\
\hline 1114 & $\mathrm{~m} 3 / \mathrm{yr}$ & $\mathrm{B}$ & 19904 & 19261 & 27349.4 & 25255 & 21426 & 25992 & 32720 & 24558.2 & 0.63 & 0.25 & 256.7925 & 25679.25 & $5 \%$ & $4.6 \%$ \\
\hline 1115 & $\mathrm{~m} 3 / \mathrm{yr}$ & C & 20814 & 19541 & 29739.4 & 27075 & 23186 & 26953 & 34900 & 26029.8 & 0.65 & 0.25 & 267.0642 & 26706.42 & $3 \%$ & $2.6 \%$ \\
\hline & & & & & & & & & & & & & & & Average $=$ & $3.4 \%$ \\
\hline $50 \%$ Greenro & ofs & & 1990 & 1991 & 1992 & 1993 & 1994 & 1995 & 1996 & & & & & & & \\
\hline 1101 & $\mathrm{~m} 3 / \mathrm{yr}$ & A & 19474 & 18661 & 26219.4 & - & - & - & - & 21451.5 & 0.54 & 0.25 & 223.0603 & 22306.03 & $4 \%$ & $4.0 \%$ \\
\hline 1102 & $\mathrm{~m} 3 / \mathrm{yr}$ & $B$ & 19904 & 18671 & 27289.4 & - & - & - & - & 21954.8 & 0.57 & 0.25 & 232.7567 & 23275.67 & $6 \%$ & $6.0 \%$ \\
\hline 1103 & $\mathrm{~m} 3 / \mathrm{yr}$ & C & 20914 & 19231 & 29999.4 & - & - & - & - & 23381.5 & 0.60 & 0.25 & 244.8774 & 24487.74 & $5 \%$ & $4.7 \%$ \\
\hline 1104 & $\mathrm{~m} 3 / \mathrm{yr}$ & $\mathrm{A}$ & 19474 & 18661 & 26219.4 & - & - & - & - & 21451.5 & 0.54 & 0.25 & 223.0603 & 22306.03 & $4 \%$ & $4.0 \%$ \\
\hline 1105 & $\mathrm{~m} 3 / \mathrm{yr}$ & $B$ & 19904 & 18671 & 27289.4 & - & - & - & - & 21954.8 & 0.57 & 0.25 & 232.7567 & 23275.67 & $6 \%$ & $6.0 \%$ \\
\hline 1106 & $\mathrm{~m} 3 / \mathrm{yr}$ & $\mathrm{C}$ & 20914 & 19231 & 29999.4 & - & - & - & - & 23381.5 & 0.60 & 0.25 & 244.8774 & 24487.74 & $5 \%$ & $4.7 \%$ \\
\hline 1113 & $\mathrm{~m} 3 / \mathrm{yr}$ & A & 19474 & 19251 & 26299.4 & - & - & - & - & 21674.8 & 0.54 & 0.25 & 223.0603 & 22306.03 & $3 \%$ & $2.9 \%$ \\
\hline 1114 & $\mathrm{~m} 3 / \mathrm{yr}$ & $B$ & 19904 & 19261 & 27349.4 & - & - & - & - & 22171.5 & 0.57 & 0.25 & 232.7567 & 23275.67 & $5 \%$ & $5.0 \%$ \\
\hline 1115 & $\mathrm{~m} 3 / \mathrm{yr}$ & C & 20814 & 19541 & 29739.4 & - & - & - & - & 23364.8 & 0.60 & 0.25 & 244.8774 & 24487.74 & $5 \%$ & $4.8 \%$ \\
\hline & & & & & & & & & & & & & & & Average $=$ & $4.7 \%$ \\
\hline $100 \%$ Greenr & roofs & & 1990 & 1991 & 1992 & 1993 & 1994 & 1995 & 1996 & & & & & & & \\
\hline \begin{tabular}{r|}
1101 \\
\end{tabular} & $\mathrm{~m} 3 / \mathrm{yr}$ & A & 19474 & 18661 & 26219.4 & - & - & - & - & 21451.5 & 0.48 & 0.25 & 197.5454 & 19754.54 & $-8 \%$ & $7.9 \%$ \\
\hline 1102 & $\mathrm{~m} 3 / \mathrm{yr}$ & $B$ & 19904 & 18671 & 27289.4 & - & - & - & - & 21954.8 & 0.51 & 0.25 & 208.721 & 20872.1 & $-5 \%$ & $4.9 \%$ \\
\hline 1103 & $\mathrm{~m} 3 / \mathrm{yr}$ & $C$ & 20914 & 19231 & 29999.4 & - & - & - & - & 23381.5 & 0.54 & 0.25 & 222.6905 & 22269.05 & $-5 \%$ & $4.8 \%$ \\
\hline 1104 & $\mathrm{~m} 3 / \mathrm{yr}$ & A & 19474 & 18661 & 26219.4 & - & - & - & - & 21451.5 & 0.48 & 0.25 & 197.5454 & 19754.54 & $-8 \%$ & $7.9 \%$ \\
\hline 1105 & $\mathrm{~m} 3 / \mathrm{yr}$ & $B$ & 19904 & 18671 & 27289.4 & - & - & - & - & 21954.8 & 0.51 & 0.25 & 208.721 & 20872.1 & $-5 \%$ & $4.9 \%$ \\
\hline 1106 & $\mathrm{~m} 3 / \mathrm{yr}$ & C & 20914 & 19231 & 29999.4 & - & - & - & - & 23381.5 & 0.54 & 0.25 & 222.6905 & 22269.05 & $-5 \%$ & $4.8 \%$ \\
\hline 1113 & $\mathrm{~m} 3 / \mathrm{yr}$ & A & 19474 & 19251 & 26299.4 & - & - & - & - & 21674.8 & 0.48 & 0.25 & 197.5454 & 19754.54 & $-9 \%$ & $8.9 \%$ \\
\hline 1114 & $\mathrm{~m} 3 / \mathrm{yr}$ & $B$ & 19904 & 19261 & 27349.4 & - & - & - & - & 22171.5 & 0.51 & 0.25 & 208.721 & 20872.1 & $-6 \%$ & $5.9 \%$ \\
\hline 1115 & $\mathrm{~m} 3 / \mathrm{yr}$ & C & 20814 & 19541 & 29739.4 & - & - & - & - & 23364.8 & 0.54 & 0.25 & 222.6905 & 22269.05 & $-5 \%$ & $4.7 \%$ \\
\hline & & & & & & & & & & & & & & & Average = & $6.1 \%$ \\
\hline
\end{tabular}




\section{High Density Residential}

\section{Data}

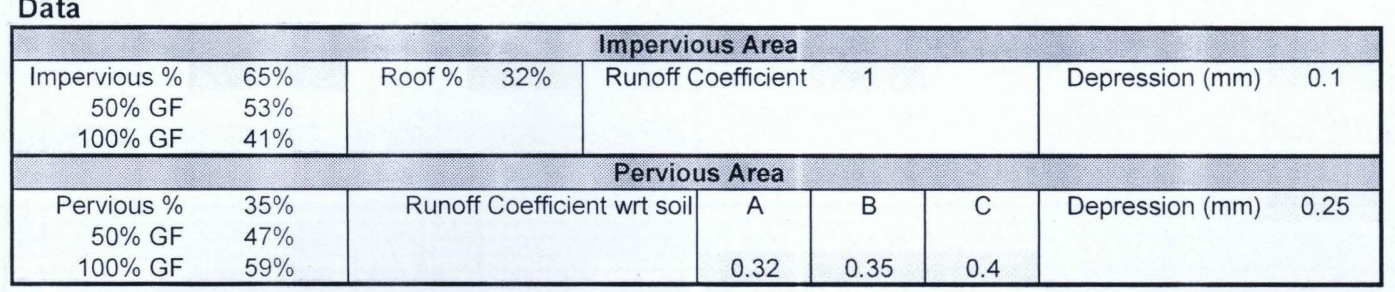

$=$ User Input

= Calibrating User Input

$\stackrel{\bullet}{\bullet}$

\begin{tabular}{|c|c|c|c|c|c|c|c|c|c|c|c|c|c|c|}
\hline \multicolumn{2}{|c|}{ No Green Roofs } & \multirow[b]{2}{*}{ Soil Type } & \multicolumn{8}{|c|}{ HSPF DATA } & \multicolumn{4}{|c|}{ ANALYTICAL MODEL DATA } \\
\hline Scenario & Constituent & & 1990 & 1991 & 1992 & 1993 & 1994 & 1995 & 1996 & Average & $\begin{array}{c}\text { Runoff } \\
\text { Coefficient }\end{array}$ & Depression & $\begin{array}{c}\text { Runoff } \\
\text { (mm) }\end{array}$ & $\begin{array}{c}\text { Runoff } \\
\text { m3 }\end{array}$ \\
\hline 1201 & $\mathrm{~m} 3 / \mathrm{yr}$ & A & 24878 & 24600 & 33613.5 & 31695 & 26080 & 33150 & 40560 & 30653.8 & 0.76 & 0.15 & 321.1195 & 32111. \\
\hline 1202 & $\mathrm{~m} 3 / \mathrm{yr}$ & B & 25208 & 24630 & 34413.5 & 32125 & 26880 & 33220 & 41340 & 31116.6 & 0.77 & 0.15 & 325.5444 & 32554.44 \\
\hline 1203 & $\mathrm{~m} 3 / \mathrm{yr}$ & C & 26008 & 24940 & 36523.5 & 33815 & 28540 & 34310 & 43410 & 32506.6 & 0.79 & 0.15 & 332.9192 & 33291.92 \\
\hline 1204 & $\mathrm{~m} 3 / \mathrm{yr}$ & A & 24878 & 24600 & 33613.5 & 31695 & 26080 & 33150 & 40560 & 30653.8 & 0.76 & 0.15 & 321.1195 & 32111.95 \\
\hline 1205 & $\mathrm{~m} 3 / \mathrm{yr}$ & $B$ & 25208 & 24630 & 34413.5 & 32125 & 26880 & 33220 & 41340 & 31116.6 & 0.77 & 0.15 & 325.5444 & 32554.44 \\
\hline 1206 & $\mathrm{~m} 3 / \mathrm{yr}$ & $\mathrm{C}$ & 26008 & 24940 & 36523.5 & 33815 & 28540 & 34310 & 43410 & 32506.6 & 0.79 & 0.15 & 332.9192 & 33291.92 \\
\hline 1213 & $\mathrm{~m} 3 / \mathrm{yr}$ & A & 24878 & 24600 & 33613.5 & 31695 & 26080 & 33150 & 40560 & 30653.8 & 0.76 & 0.15 & 321.1195 & 32111.95 \\
\hline 1214 & $\mathrm{~m} 3 / \mathrm{yr}$ & $B$ & 25208 & 24630 & 34413.5 & 32125 & 26880 & 33220 & 41340 & 31116.6 & 0.77 & 0.15 & 325.5444 & 32554.44 \\
\hline 1215 & $\mathrm{~m} 3 / \mathrm{yr}$ & C & 25928 & 24910 & 36313.5 & 33645 & 28290 & 34150 & 43140 & 32339.5 & 0.79 & 0.15 & 332.9192 & 33291.92 \\
\hline
\end{tabular}

\begin{tabular}{|r|c|r|}
\hline $50 \%$ Greenroofs \\
\hline 1201 & $\mathrm{~m} 3 / \mathrm{yr}$ & \\
\hline 1202 & $\mathrm{~m} 3 / \mathrm{yr}$ & \\
\hline 1203 & $\mathrm{~m} 3 / \mathrm{yr}$ & \\
\hline 1204 & $\mathrm{~m} 3 / \mathrm{yr}$ & \\
\hline 1205 & $\mathrm{~m} 3 / \mathrm{yr}$ & \\
\hline 1206 & $\mathrm{~m} 3 / \mathrm{yr}$ & \\
\hline 1213 & $\mathrm{~m} 3 / \mathrm{yr}$ & \\
\hline 1214 & $\mathrm{~m} 3 / \mathrm{yr}$ & \\
\hline 1215 & $\mathrm{~m} 3 / \mathrm{yr}$ & \\
\hline & & \\
\hline & &
\end{tabular}

\begin{tabular}{|l|l|l|l|l|l|l|}
\hline 1990 & 1991 & 1992 & 1993 & 1994 & 1995 & 1996 \\
\hline
\end{tabular}

\begin{tabular}{|l|c|c|c|c|c|c|c|}
\hline 24878 & 23830 & 33533.5 & - & - & - & & 27413.8
\end{tabular}

\begin{tabular}{c|c|c|c|c|}
\hline 1995 & 1996 & \multicolumn{3}{|c|}{} \\
\hline- & - & 27413.8 & 0.68 & \\
- & - & 27807.2 & 0.69 & \\
- & - & 28957.2 & 0.72 & \\
- & - & 27413.8 & 0.68 & \\
- & - & 27807.2 & 0.69 & \\
- & - & 28957.2 & 0.72 & \\
- & - & 27697.2 & 0.68 & \\
- & - & 28083.8 & 0.69 &
\end{tabular}

Comparison Data

\begin{tabular}{|r|c|l|}
\hline $\mathbf{1 0 0 \%}$ Greenroofs \\
\hline 1201 & $\mathrm{~m} 3 / \mathrm{yr}$ & \\
\hline 1202 & $\mathrm{~m} 3 / \mathrm{yr}$ & \\
\hline 1203 & $\mathrm{~m} 3 / \mathrm{yr}$ & \\
\hline 1204 & $\mathrm{~m} 3 / \mathrm{yr}$ & \\
\hline 1205 & $\mathrm{~m} 3 / \mathrm{yr}$ & \\
\hline 1206 & $\mathrm{~m} 3 / \mathrm{yr}$ & \\
\hline 1213 & $\mathrm{~m} 3 / \mathrm{yr}$ & \\
\hline 1214 & $\mathrm{~m} 3 / \mathrm{yr}$ & \\
\hline 1215 & $\mathrm{~m} 3 / \mathrm{yr}$ & \\
\hline & & \\
\hline &
\end{tabular} \begin{tabular}{l|l|l|l|l|} 
B & 25208 & 24630 & 34413.5 \\
\hline C & 25928 & 24910 & 36313.5
\end{tabular}

\begin{tabular}{|c|c|c|c|c|}
\hline 60 & 33533.5 & - & - & \\
\hline 40 & 34353.5 & - & - & \\
30 & 33533.5 & - & - & \\
60 & 34353.5 & - & - & \\
40 & 36523.5 & - & - & - \\
\hline 0 & 33613.5 & - & - & \\
\hline 0 & 34413.5 & - & - & - \\
10 & 36313.5 & - & - & - \\
\hline
\end{tabular}

\begin{tabular}{|l|l|l|l|l|}
\hline 0.17 & 285.3931 & 28539.31 & $4 \%$ & $4.1 \%$ \\
\hline 0.17 & 291.3074 & 29130.74 & $5 \%$ & $4.8 \%$ \\
\hline 0.17 & 301.1644 & 30116.44 & $4 \%$ & $4.0 \%$ \\
\hline 0.17 & 285.3931 & 28539.31 & $4 \%$ & $4.1 \%$ \\
\hline 0.17 & 291.3074 & 29130.74 & $5 \%$ & $4.8 \%$ \\
\hline 0.17 & 301.1644 & 30116.44 & $4 \%$ & $4.0 \%$ \\
\hline 0.17 & 285.3931 & 28539.31 & $3 \%$ & $3.0 \%$ \\
\hline 0.17 & 291.3074 & 29130.74 & $4 \%$ & $3.7 \%$ \\
\hline 0.17 & 301.1644 & 30116.44 & $4 \%$ & $3.7 \%$ \\
\hline \multicolumn{5}{|c|}{ Average = $4.0 \%$} \\
\hline
\end{tabular}

\begin{tabular}{|l|l|l|}
\hline A & & \\
B & 25 \\
\hline C & & \\
A & 24 \\
\hline B & 25 \\
C & 20 \\
A & 24 \\
\hline B & & \\
C & & \\
\hline
\end{tabular}

\begin{tabular}{|c|c|c|c|c|c|}
\hline 1990 & 1991 & 1992 & 1993 & 1994 & 199 \\
\hline 24878 & 23830 & 33533.5 & - & - & \\
\hline 25208 & 23860 & 34353.5 & - & - & \\
\hline 26008 & 24340 & 36523.5 & - & - & \\
\hline 24878 & 23830 & 33533.5 & - & - & \\
\hline 25208 & 23860 & 34353.5 & - & - & \\
\hline 26008 & 24340 & 36523.5 & - & - & \\
\hline 24878 & 24600 & 33613.5 & - & - & \\
\hline 25208 & 24630 & 34413.5 & - & - & \\
\hline 25928 & 24910 & 36313.5 & - & - & \\
\hline
\end{tabular}

\begin{tabular}{|c|c|}
\hline 1995 & 1996 \\
\hline- & \\
\hline- & - \\
\hline- & - \\
\hline- & \\
\hline- & \\
\hline- & - \\
\hline- & - \\
\hline- & \\
\hline- & - \\
\hline
\end{tabular}

\begin{tabular}{|l|l|l|}
\hline & & \\
\hline & 27413.8 & 0.6 \\
\hline 27807.2 & 0.6 \\
\hline 28957.2 & 0.6 \\
\hline 27413.8 & 0.6 \\
\hline 27807.2 & 0.6 \\
\hline 28957.2 & 0.6 \\
\hline 27697.2 & 0.6 \\
\hline 28083.8 & 0.6 \\
\hline 29050.5 & 0.6 \\
\hline
\end{tabular}

\begin{tabular}{l|l}
\hline 0.60 & \\
\hline 0.62 & \\
\hline 0.65 & \\
\hline 0.60 & \\
\hline 0.62 & \\
\hline 0.65 & \\
\hline 0.60 & \\
\hline 0.62 & 0. \\
\hline 0.65 & \\
\hline
\end{tabular}

\begin{tabular}{|c|c|c|c|c|}
\hline \multicolumn{7}{|l|}{} & & \\
\hline 0.19 & 249.9934 & 24999.34 & $-9 \%$ & $8.8 \%$ \\
\hline 0.19 & 257.383 & 25738.3 & $-7 \%$ & $7.4 \%$ \\
\hline 0.19 & 269.6989 & 26969.89 & $-7 \%$ & $6.9 \%$ \\
\hline 0.19 & 249.9934 & 24999.34 & $-9 \%$ & $8.8 \%$ \\
\hline 0.19 & 257.383 & 25738.3 & $-7 \%$ & $7.4 \%$ \\
\hline 0.19 & 269.6989 & 26969.89 & $-7 \%$ & $6.9 \%$ \\
\hline 0.19 & 249.9934 & 24999.34 & $-10 \%$ & $9.7 \%$ \\
\hline 0.19 & 257.383 & 25738.3 & $-8 \%$ & $8.4 \%$ \\
\hline 0.19 & 269.6989 & 26969.89 & $-7 \%$ & $7.2 \%$ \\
\hline \multicolumn{7}{|c|}{} & Average $=7.9 \%$ \\
\hline
\end{tabular}




\section{High Rise Residential}

Data

\begin{tabular}{|c|c|c|c|c|c|c|c|c|c|}
\hline \multicolumn{10}{|c|}{ Impervious Area } \\
\hline $\begin{array}{r}\text { No Green Roof } \\
50 \% \mathrm{GF} \\
100 \% \mathrm{GF}\end{array}$ & $\begin{array}{l}50 \% \\
47 \% \\
43 \% \\
\end{array}$ & Roof \% & $9 \%$ & \multicolumn{2}{|c|}{ Runoff Coefficien } & \multicolumn{2}{|l|}{0.95} & Depression (mm) & 0.25 \\
\hline \multicolumn{10}{|c|}{ Pervious Area } \\
\hline $\begin{array}{r}\text { No Green Roof } \\
50 \% \text { GF } \\
100 \% \text { GF }\end{array}$ & $\begin{array}{l}50 \% \\
53 \% \\
57 \% \\
\end{array}$ & \multicolumn{3}{|c|}{ Runoff Coefficient wrt soil } & $\begin{array}{c}A \\
0.21\end{array}$ & $\begin{array}{c}B \\
0.24\end{array}$ & $\begin{array}{l}C \\
0.3 \\
\end{array}$ & Depression (mm) & 0.5 \\
\hline
\end{tabular}

= User Input

= Calibrating User Input

Comparison Data

\begin{tabular}{|c|c|c|c|c|c|c|c|c|c|c|c|c|c|c|c|c|}
\hline \multicolumn{2}{|c|}{ No Green Roofs } & \multirow[b]{2}{*}{ Soil Type } & \multicolumn{8}{|c|}{ HSPF DATA } & \multicolumn{4}{|c|}{ ANALYTICAL MODEL DATA } & \multirow[b]{2}{*}{$\begin{array}{c}\text { Percent } \\
\text { Difference }\end{array}$} & \multirow[b]{2}{*}{ Absolute } \\
\hline Scenario & Constituent & & 1990 & 1991 & 1992 & 1993 & 1994 & 1995 & 1996 & Average & \begin{tabular}{c|c} 
Runoff \\
Coefficient
\end{tabular} & Depression & $\begin{array}{c}\text { Runoff } \\
(\mathrm{mm})\end{array}$ & $\begin{array}{c}\text { Runoff } \\
\text { m3 }\end{array}$ & & \\
\hline 1301 & $\mathrm{~m} 3 / \mathrm{yr}$ & A & 19193 & 19176 & 26523.7 & 24913 & 19940 & 25920 & 31980 & 23949.4 & \begin{tabular}{l|l}
0.58 \\
\end{tabular} & 0.38 & 230.683 & 23068.31 & $-4 \%$ & $3.7 \%$ \\
\hline 1302 & $\mathrm{~m} 3 / \mathrm{yr}$ & B & 19493 & 19186 & 27313.7 & 25123 & 20630 & 25940 & 32590 & 24325.1 & 0.60 & 0.38 & 236.649 & 23664.9 & $-3 \%$ & $2.7 \%$ \\
\hline 1303 & $\mathrm{~m} 3 / \mathrm{yr}$ & C & 20393 & 19266 & 29593.7 & 26683 & 22341 & 26430 & 34430 & 25591 & 0.63 & 0.38 & 248.581 & 24858.09 & $-3 \%$ & $2.9 \%$ \\
\hline 1304 & $\mathrm{~m} 3 / \mathrm{yr}$ & A & 19193 & 19176 & 26523.7 & 24923 & 19940 & 25920 & 31980 & 23950.8 & 0.58 & 0.38 & 230.683 & 23068.31 & $-4 \%$ & $3.7 \%$ \\
\hline 1305 & $\mathrm{~m} 3 / \mathrm{yr}$ & $B$ & 19493 & 19186 & 27313.7 & 25123 & 20630 & 25950 & 32590 & 24326.5 & 0.60 & 0.38 & 236.649 & 23664.9 & $-3 \%$ & $2.7 \%$ \\
\hline 1306 & $\mathrm{~m} 3 / \mathrm{yr}$ & C & 20313 & 19256 & 29373.7 & 26493 & 22111 & 26330 & 34150 & 25432.4 & 0.63 & 0.38 & 248.581 & 24858.09 & \begin{tabular}{|l|l}
$-2 \%$ \\
\end{tabular} & $2.3 \%$ \\
\hline \multirow{2}{*}{\multicolumn{3}{|c|}{$50 \%$ Green Roofs }} & & & & & & & & & & & & & \multicolumn{2}{|c|}{ Average $=3.0 \%$} \\
\hline & & $50 \%$ Green Roofs & 1990 & 1991 & 1992 & 1993 & 1994 & 1995 & 1996 & Average & & & & & & \\
\hline 1301 & $\mathrm{~m} 3 / \mathrm{yr}$ & A & 19193 & 17724.6 & 25576.7 & - & - & - & - & 20831.4 & 0.56 & 0.38 & 220.266 & 22026.61 & $6 \%$ & $5.7 \%$ \\
\hline 1302 & $\mathrm{~m} 3 / \mathrm{yr}$ & B & 19493 & 17744.6 & 26316.7 & - & - & - & - & 21184.8 & 0.57 & 0.38 & 226.621 & 22662.08 & $7 \%$ & $7.0 \%$ \\
\hline 1303 & $\mathrm{~m} 3 / \mathrm{yr}$ & $\mathrm{C}$ & 20393 & 18084.6 & 28626.7 & - & - & - & - & 22368.1 & 0.60 & 0.38 & 239.33 & 23933.01 & $7 \%$ & $7.0 \%$ \\
\hline 1304 & $\mathrm{~m} 3 / \mathrm{yr}$ & A & 19193 & 19176 & 26523.7 & - & - & - & - & 21630.9 & 0.56 & 0.38 & 220.266 & 22026.61 & $2 \%$ & $1.8 \%$ \\
\hline 1305 & $\mathrm{~m} 3 / \mathrm{yr}$ & B & 19493 & 19186 & 27313.7 & - & - & - & - & 21997.6 & 0.57 & 0.38 & 226.621 & 22662.08 & $3 \%$ & $3.0 \%$ \\
\hline 1306 & $\mathrm{~m} 3 / \mathrm{yr}$ & $\mathrm{C}$ & 20313 & 19256 & 29373.7 & - & - & - & - & 22980.9 & 0.60 & 0.38 & 239.33 & 23933.01 & $4 \%$ & $4.1 \%$ \\
\hline & & & & & & & & & & & & & & & \multicolumn{2}{|c|}{ Average $=4.8 \%$} \\
\hline \multicolumn{3}{|c|}{$100 \%$ Green Roofs } & 1990 & 1991 & 1992 & 1993 & 1994 & 1995 & 1996 & Average & & & & & & \\
\hline 1301 & $\mathrm{~m} 3 / \mathrm{yr}$ & A & 19193 & 16944.3 & 24630.6 & - & - & - & - & 20256 & 0.53 & 0.39 & 209.894 & 20989.36 & $4 \%$ & $3.6 \%$ \\
\hline 1302 & $\mathrm{~m} 3 / \mathrm{yr}$ & $B$ & 19493 & 16944.3 & 25380.6 & - & - & - & - & 20606 & 0.55 & 0.39 & 216.635 & 21663.53 & $5 \%$ & $5.1 \%$ \\
\hline 1303 & $\mathrm{~m} 3 / \mathrm{yr}$ & $\mathrm{C}$ & 20393 & 17304.3 & 27680.6 & - & - & - & - & 21792.6 & 0.58 & 0.39 & 230.119 & 23011.87 & $6 \%$ & $5.6 \%$ \\
\hline 1304 & $\mathrm{~m} 3 / \mathrm{yr}$ & A & 19193 & 19176 & 26523.7 & - & - & - & - & 21630.9 & 0.53 & 0.39 & 209.894 & 20989.36 & $-3 \%$ & $3.0 \%$ \\
\hline 1305 & $\mathrm{~m} 3 / \mathrm{yr}$ & $\mathrm{B}$ & 19493 & 19186 & 27313.7 & - & - & - & - & 21997.6 & 0.55 & 0.39 & 216.635 & 21663.53 & $-2 \%$ & $1.5 \%$ \\
\hline 1306 & $\mathrm{~m} 3 / \mathrm{yr}$ & C & 20313 & 19256 & 29373.7 & - & - & - & - & 22980.9 & 0.58 & 0.39 & 230.119 & 23011.87 & $0 \%$ & $0.1 \%$ \\
\hline & & & & & & & & & & & & & & & \multicolumn{2}{|c|}{ Average $=3.2 \%$} \\
\hline
\end{tabular}




\section{Commercial}

Data

\begin{tabular}{|c|c|c|c|c|c|c|c|}
\hline \multicolumn{8}{|c|}{ Impervious Area } \\
\hline & Downtown & Big Box & Strip Mall & \multirow{5}{*}{ Runoff Coefficient } & \multirow{5}{*}{1} & \multirow{5}{*}{ Depression (mm) } & \multirow{5}{*}{0} \\
\hline Roof \% & $95 \%$ & $29 \%$ & $17 \%$ & & & & \\
\hline No Green Roof & $95 \%$ & $96 \%$ & $96 \%$ & & & & \\
\hline $50 \% \mathrm{GF}$ & $59 \%$ & $85 \%$ & $90 \%$ & & & & \\
\hline $100 \% \mathrm{GF}$ & $24 \%$ & $74 \%$ & $83 \%$ & & & & \\
\hline \multicolumn{8}{|c|}{ Pervious Area } \\
\hline & Downtown & Big Box & Strip Mall & \multirow{4}{*}{$\begin{array}{c}\text { Soil Type } \\
\text { B }\end{array}$} & & \multirow[t]{4}{*}{ Depression (mm) } & \multirow[t]{4}{*}{0.5} \\
\hline No Green Roof & $5 \%$ & $4 \%$ & $4 \%$ & & & & \\
\hline $50 \% \mathrm{GF}$ & $41 \%$ & $15 \%$ & $10 \%$ & & & & \\
\hline $100 \%$ GF & $76 \%$ & $26 \%$ & $17 \%$ & & & & \\
\hline
\end{tabular}

= User Input

= Calibrating User Input

Comparison Data

$\stackrel{\circ}{\omega}$

\begin{tabular}{|c|c|c|c|c|c|c|c|c|c|c|c|c|c|c|c|c|}
\hline \multicolumn{2}{|c|}{ No Green Roofs } & \multirow[b]{2}{*}{ Soil Type } & \multicolumn{8}{|c|}{ HSPF DATA } & \multicolumn{4}{|c|}{ ANALYTICAL MODEL DATA } & \multirow[b]{2}{*}{$\begin{array}{l}\text { Percent } \\
\text { Difference }\end{array}$} & \multirow[b]{2}{*}{ Absolute } \\
\hline Scenario & Type & & 1990 & 1991 & 1992 & 1993 & 1994 & 1995 & 1996 & Average & $\begin{array}{c}\text { Runoff } \\
\text { Coefficient }\end{array}$ & Depression & \begin{tabular}{|c|}
$\begin{array}{c}\text { Runoff } \\
(\mathrm{mm})\end{array}$ \\
\end{tabular} & $\begin{array}{c}\text { Runoff } \\
\text { m3 }\end{array}$ & & \\
\hline 2001 & Downtown & B & 36261 & 36230 & 50207.7 & 47045 & 37510 & 48940 & 60360 & 45222 & 0.99 & 0.03 & 431.265 & 43126.5 & $-5 \%$ & $4.6 \%$ \\
\hline 2101 & Big Box & B & 37608.1 & 37550 & 51841.5 & 48779 & 38860 & 50770 & 62420 & 46832.7 & 0.99 & 0.02 & 432.698 & 43269.8 & $-8 \%$ & $7.6 \%$ \\
\hline 2201 & Strip Mall & B & 37513.1 & 37460 & 51731.7 & 48659 & 38760 & 50650 & 62340 & 46730.5 & 0.99 & 0.02 & 432.698 & 43269.8 & $-7 \%$ & $7.4 \%$ \\
\hline & & & & & & & & & & & & & & & \multirow{2}{*}{\multicolumn{2}{|c|}{ Average $=6.5 \%$}} \\
\hline \multicolumn{3}{|c|}{$50 \%$ Green Roofs } & 1990 & 1991 & 1992 & 1993 & 1994 & 1995 & 1996 & Average & & & & & & \\
\hline 2001 & Downtown & $\mathrm{B}$ & 36261 & 29510 & 42189.6 & - & - & - & - & 35986.9 & 0.92 & 0.20 & 382.114 & 38211.4 & $6 \%$ & $6.2 \%$ \\
\hline 2101 & Big Box & B & 37608.1 & 35049 & 51969.7 & - & - & - & - & 41542.3 & 0.97 & 0.2 & 403.533 & 40353.3 & $-3 \%$ & $2.9 \%$ \\
\hline 2201 & Strip Mall & $B$ & 37513.1 & 32584 & 47531.7 & - & - & - & - & 39209.6 & 0.98 & 0.20 & 407.276 & 40727.6 & $4 \%$ & $3.9 \%$ \\
\hline & & & & & & & & & & & & & & & \multirow{2}{*}{\multicolumn{2}{|c|}{ Average $=4.3 \%$}} \\
\hline \multicolumn{3}{|c|}{$100 \%$ Green Roofs } & 1990 & 1991 & 1992 & 1993 & 1994 & 1995 & 1996 & Average & & & & & & \\
\hline 2001 & Downtown & B & 36261 & 28419 & 42415.8 & - & - & - & - & 35698.6 & 0.85 & 0.20 & 352.48 & 35248 & $-\frac{-1 \%}{1 \%}$ & $1.3 \%$ \\
\hline 2101 & Big Box & B & 37608.1 & 29249 & 43601.5 & - & - & - & - & \begin{tabular}{|l|}
36819.5 \\
\end{tabular} & 0.95 & 0.20 & 394.487 & 39448.7 & $7 \%$ & $7.1 \%$ \\
\hline 2201 & Strip Mall & B & 37513.1 & 29219 & 43677.7 & - & - & - & - & 36803.3 & 0.97 & 0.20 & 401.973 & 40197.3 & $9 \%$ & $9.2 \%$ \\
\hline & & & & & & & & & & & & & & & Average $=$ & $5.9 \%$ \\
\hline
\end{tabular}




\section{Educational/Institutional}

Data

\begin{tabular}{|c|c|c|c|c|c|c|c|c|c|}
\hline \multicolumn{10}{|c|}{ Impervious Area } \\
\hline No Green Roof & $32 \%$ & Roof \% & $9 \%$ & \multicolumn{2}{|c|}{ Runoff Coefficient } & \multicolumn{2}{|l|}{0.85} & Depression (mm) & 0.5 \\
\hline $50 \%$ GF & $29 \%$ & & & & & & & & \\
\hline $100 \% \mathrm{GF}$ & $25 \%$ & & & & & & & & \\
\hline \multicolumn{10}{|c|}{ Pervious Area } \\
\hline No Green Roof & $68 \%$ & \multirow{3}{*}{\multicolumn{3}{|c|}{ Runoff Coefficient wrt soil }} & $A$ & B & C & Depression (mm) & 1.5 \\
\hline $50 \%$ GF & $71 \%$ & & & & & & & & \\
\hline $100 \%$ GF & $75 \%$ & & & & 0.27 & 0.29 & 0.37 & & \\
\hline
\end{tabular}

= User Input

= Calibrating User Input

Comparison Data

\begin{tabular}{|c|c|c|c|c|c|c|c|c|c|c|c|c|c|c|c|c|}
\hline \multicolumn{2}{|c|}{ No Green Roofs } & \multirow[b]{2}{*}{ Soil Type } & \multicolumn{8}{|c|}{ HSPF DATA } & \multicolumn{4}{|c|}{ ANALYTICAL MODEL DATA } & \multirow[b]{2}{*}{$\begin{array}{l}\text { Percent } \\
\text { Difference }\end{array}$} & \multirow[b]{2}{*}{ Absolute } \\
\hline Scenario & Constituent & & 1990 & 1991 & 1992 & 1993 & 1994 & 1995 & 1996 & Average & $\begin{array}{c}\text { Runoff } \\
\text { Coefficient }\end{array}$ & Depression & \begin{tabular}{c|}
$\begin{array}{c}\text { Runoff } \\
\text { (mm) }\end{array}$ \\
\end{tabular} & \begin{tabular}{|c|}
$\begin{array}{c}\text { Runoff } \\
\mathrm{m} 3\end{array}$ \\
\end{tabular} & & \\
\hline 3001 & $\mathrm{~m} 3 / \mathrm{yr}$ & A & 14048.1 & 12249 & 17013.6 & 15921 & 12839 & 16566 & 20551 & 15598.2 & 0.46 & 1.18 & 146.985 & 14698.5 & $-6 \%$ & $5.8 \%$ \\
\hline 3002 & $\mathrm{~m} 3 / \mathrm{yr}$ & B & 14478.1 & 12259 & 18113.6 & 16241 & 13819 & 16606 & 21400 & 16131 & 0.47 & 1.18 & 151.373 & 15137.3 & $-6 \%$ & $6.2 \%$ \\
\hline 3003 & $\mathrm{~m} 3 / \mathrm{yr}$ & C & 15908.1 & 12409 & 21243.6 & 18472 & 16230 & 17376 & 24041 & 17954.2 & 0.52 & 1.18 & 168.923 & 16892.3 & $-6 \%$ & $5.9 \%$ \\
\hline \multirow{2}{*}{\multicolumn{3}{|c|}{$50 \%$ Green Roofs }} & & & & & & & & & & & & & \multirow{2}{*}{\multicolumn{2}{|c|}{ Average $=5.9 \%$}} \\
\hline & & & 1990 & 1991 & 1992 & 1993 & 1994 & 1995 & 1996 & Average & & & & & & \\
\hline 3001 & $\mathrm{~m} 3 / \mathrm{yr}$ & A & 12288.1 & 11031.6 & \begin{tabular}{|l|}
16005.5 \\
\end{tabular} & - & - & - & - & 13108.4 & 0.44 & 1.21 & 139.441 & 13944.1 & $6 \%$ & $6.4 \%$ \\
\hline 3002 & $\mathrm{~m} 3 / \mathrm{yr}$ & B & 12718.1 & 11032.6 & \begin{tabular}{|l|}
17075.5 \\
\end{tabular} & - & - & - & - & 13608.7 & 0.45 & 1.21 & 144.006 & 14400.6 & $6 \%$ & $5.8 \%$ \\
\hline 3003 & $\mathrm{~m} 3 / \mathrm{yr}$ & C & 13958.1 & 11552.6 & 20245.5 & - & - & - & - & 15252.1 & 0.51 & 1.21 & 162.267 & 16226.7 & $6 \%$ & $6.4 \%$ \\
\hline \multirow{2}{*}{\multicolumn{3}{|c|}{$100 \%$ Green Roofs }} & \multirow{2}{*}{\multicolumn{8}{|c|}{$\begin{array}{|llllllll|}1199 & 1991 & 1992 & 1993 & 1994 & 1995 & 1996 & \text { Average } \\
1990 & 1991 & \end{array}$}} & \multicolumn{4}{|c|}{ 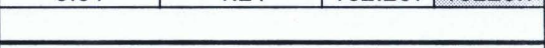 } & \multicolumn{2}{|c|}{ Average $=6.2 \%$} \\
\hline & & & & & & & & & & & & & & & \multicolumn{2}{|c|}{ 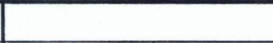 } \\
\hline 3001 & $\mathrm{~m} 3 / \mathrm{yr}$ & A & 12288.1 & 10222.3 & 15070.5 & - & - & - & - & 12527 & 0.42 & 1.25 & 132.017 & 13201.7 & \multirow{4}{*}{$\begin{array}{c}5 \% \\
5 \% \\
6 \% \\
\text { Average }=\end{array}$} & $5.4 \%$ \\
\hline \multirow{3}{*}{\begin{tabular}{r|}
3002 \\
3003 \\
\end{tabular}} & $\mathrm{~m} 3 / \mathrm{yr}$ & B & 12718.1 & 10233.3 & 16140.5 & - & - & - & - & 13030.6 & 0.43 & 1.25 & 136.757 & 13675.7 & & $5.0 \%$ \\
\hline & $\mathrm{m} 3 / \mathrm{yr}$ & $\mathrm{C}$ & 13958.1 & 10744.3 & \begin{tabular}{|l|}
19310.5 \\
\end{tabular} & - & - & - & - & 14671 & 0.49 & 1.25 & 155.714 & 15571.4 & & $6.1 \%$ \\
\hline & & & & & & & & & & & & & & & & $5.5 \%$ \\
\hline
\end{tabular}




\section{Open Space}

\section{Data}

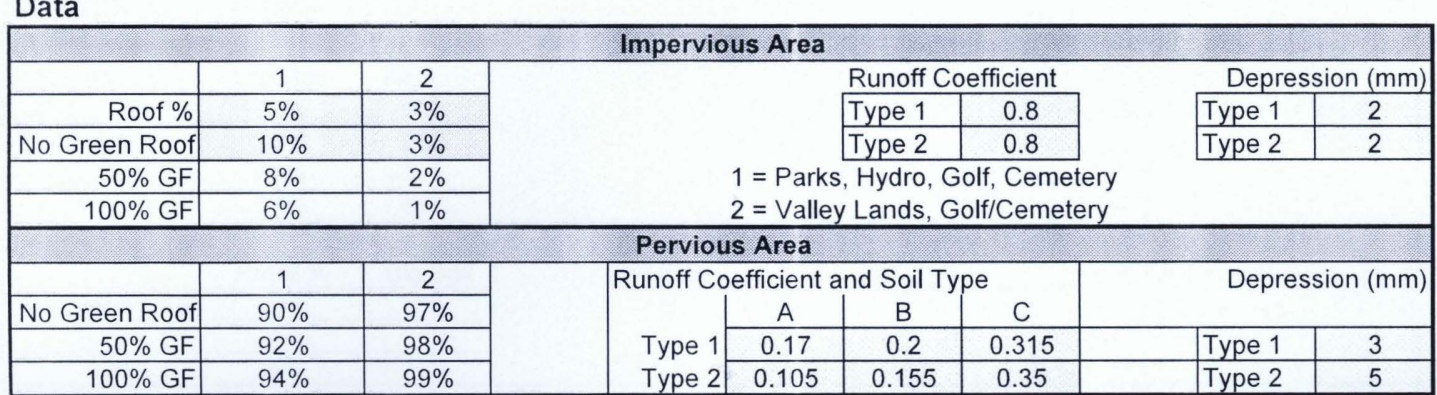

$=$ User Input

= Calibrating User Input

Comparison Data

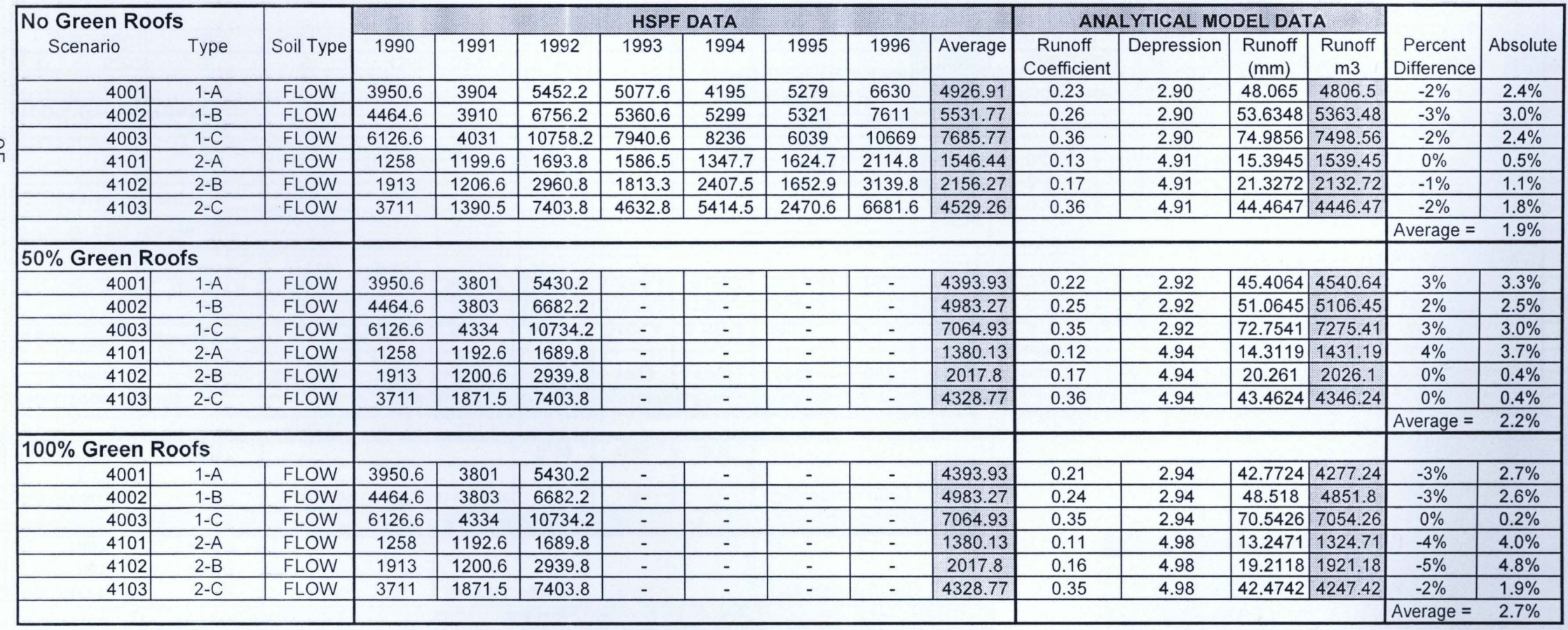




\section{Transportation Corridor}

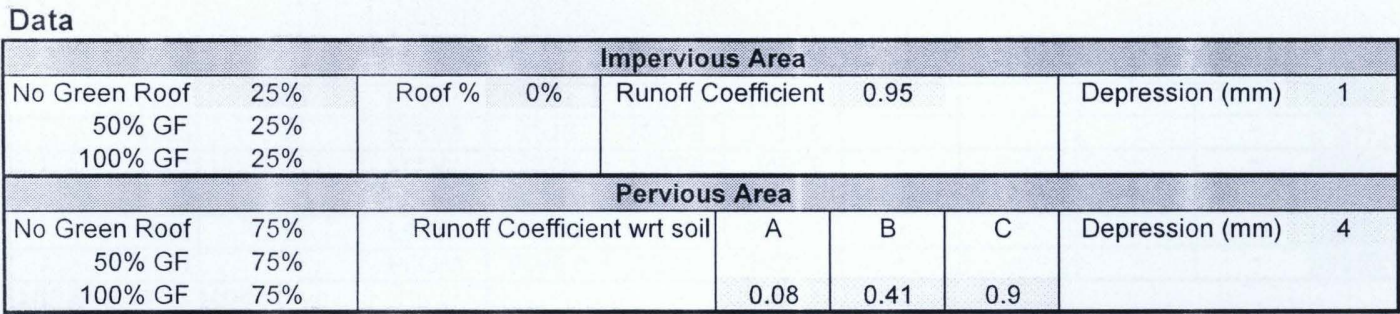

$=$ User Input

= Calibrating User Input

Comparison Data

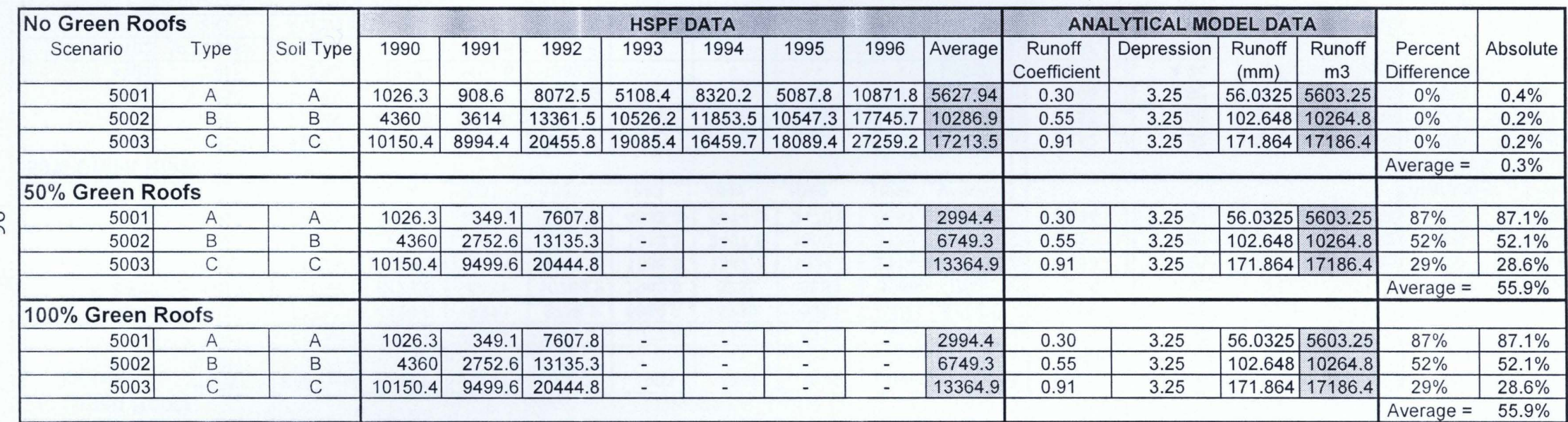




\section{Industrial}

Data

\begin{tabular}{|c|c|c|c|c|c|c|c|c|}
\hline \multicolumn{9}{|c|}{ Impervious Area } \\
\hline & Prestige & Big Box & & \multirow{2}{*}{\multicolumn{2}{|c|}{ Runoff Coefficient }} & & \multirow{5}{*}{ Depression $(\mathrm{mm})$} & \multirow{5}{*}{0.1} \\
\hline Roof \% & $30 \%$ & $7 \%$ & & & & 0.9 & & \\
\hline No Green Roof & $80 \%$ & $93 \%$ & & & & & & \\
\hline $50 \% \mathrm{GF}$ & $69 \%$ & $90 \%$ & & & & & & \\
\hline $100 \% \mathrm{GF}$ & $58 \%$ & $88 \%$ & & & & & & \\
\hline \multicolumn{9}{|c|}{ Pervious Area } \\
\hline & Prestige & Big Box & Big Bor & & Soil Type & & \multirow[t]{4}{*}{ Depression (mm) } & \multirow[t]{4}{*}{0.1} \\
\hline No Green Roof & $20 \%$ & $7 \%$ & \multirow[t]{2}{*}{$B$} & \multirow[t]{2}{*}{ A } & \multirow[t]{2}{*}{$B$} & \multirow[t]{2}{*}{ C } & & \\
\hline $50 \% \mathrm{GF}$ & $31 \%$ & $10 \%$ & & & & & & \\
\hline $100 \%$ GF & $43 \%$ & $12 \%$ & 0.8 & 0.53 & 0.55 & 0.59 & & \\
\hline
\end{tabular}

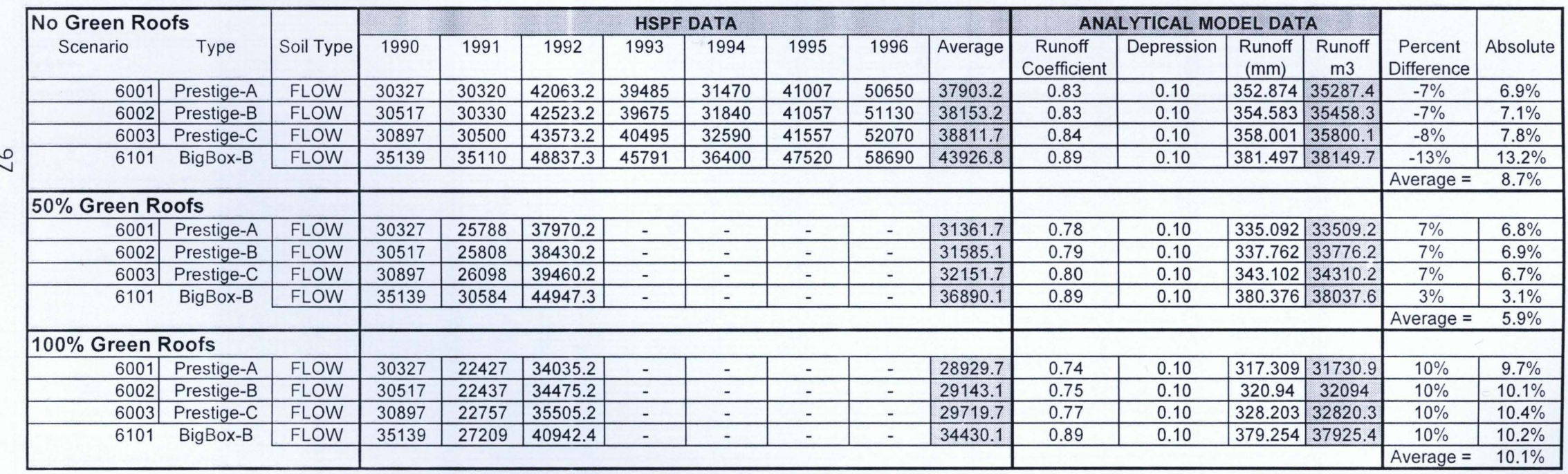

= User Input

= Calibrating User Input

Comparison Data 
Total Annual Runoff - Highland Creek Watershed

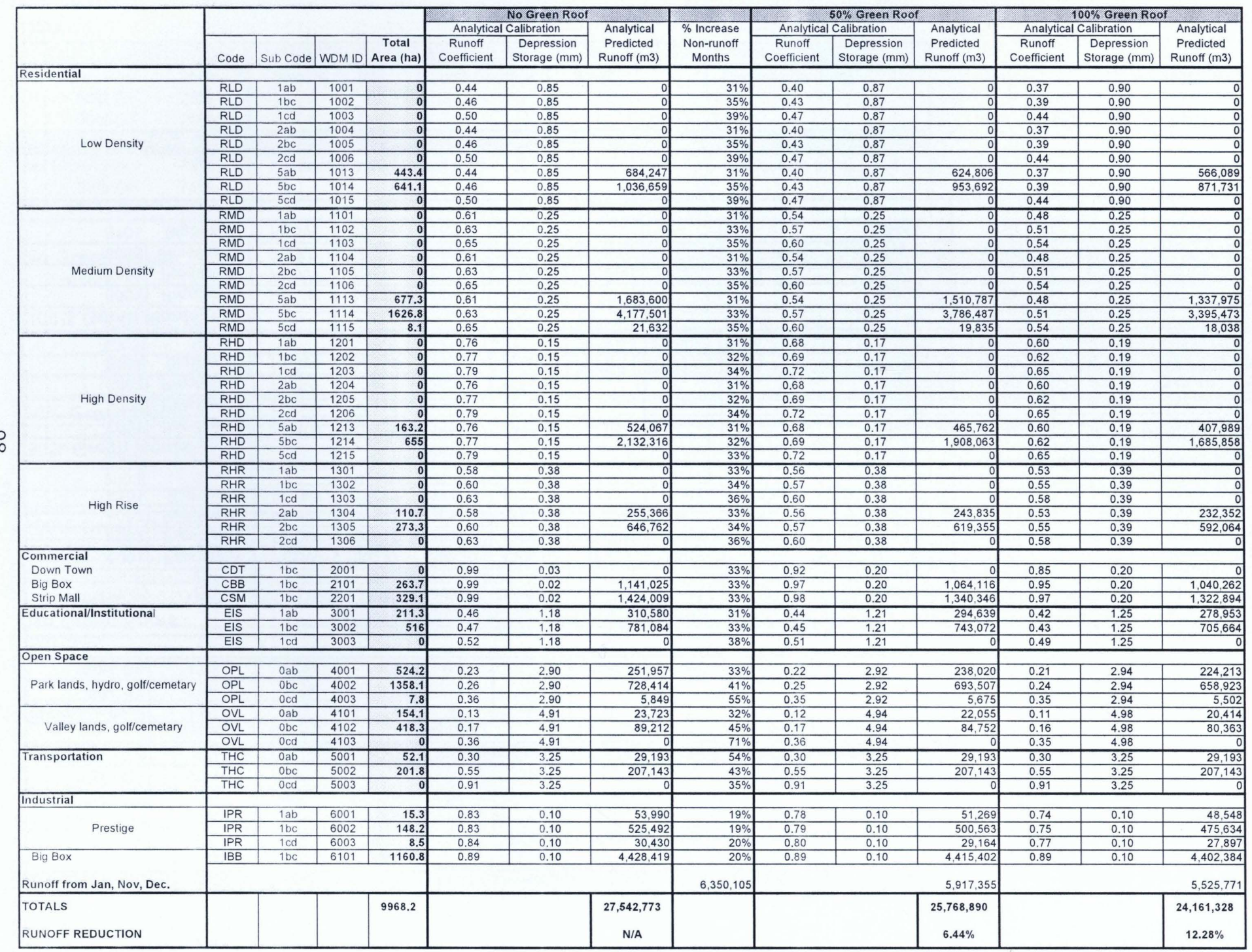


Total Annual Runoff - Markham Branch

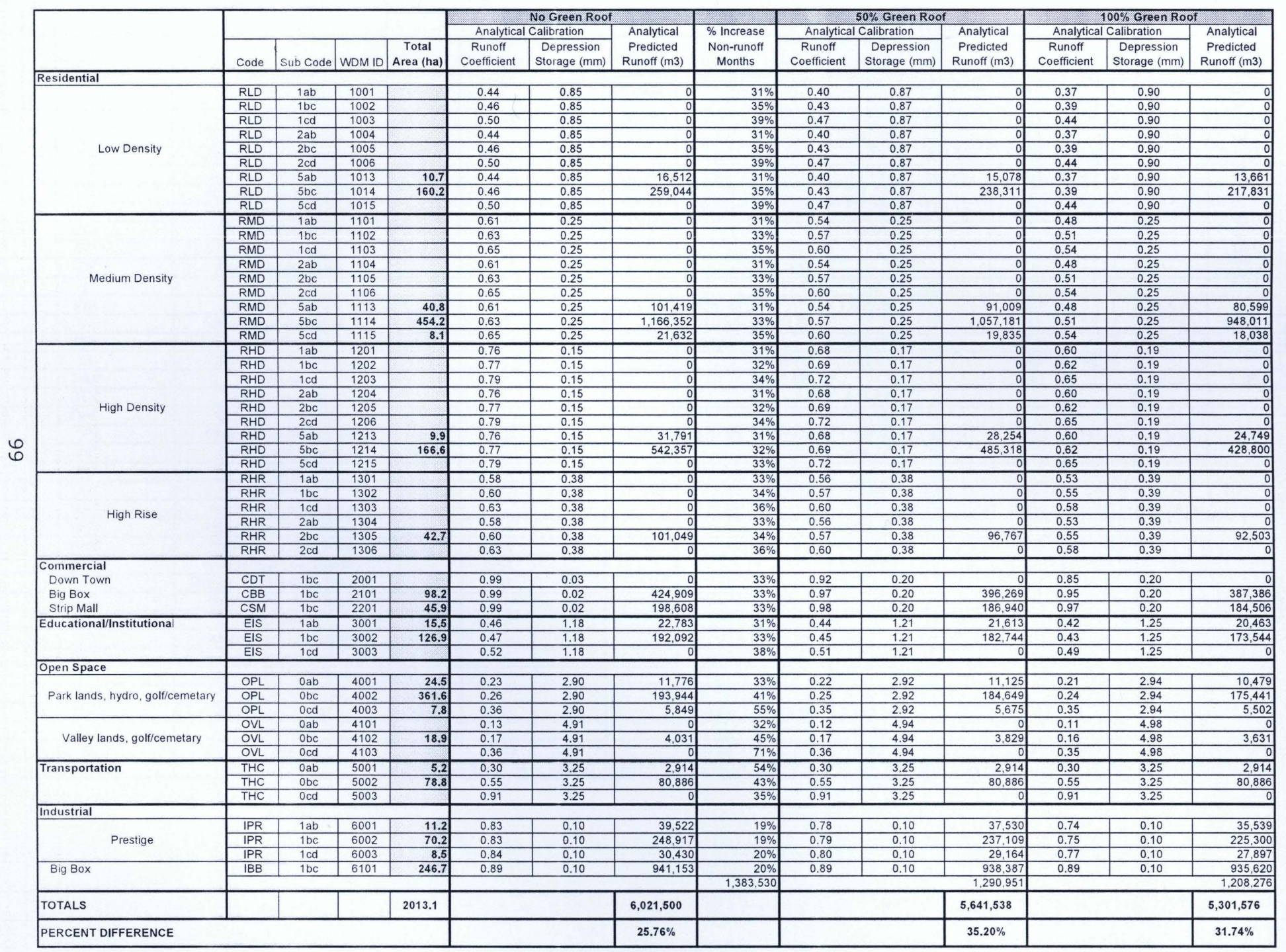


Appendix E: Additional Watershed Land Use Data and Runoff Tables

(BANTING et AL., 2005) 


\begin{tabular}{|c|c|c|c|c|c|c|c|c|c|c|c|c|c|c|c|c|}
\hline & & \multicolumn{15}{|c|}{ Watershed } \\
\hline Land Use Code & Description & Don River & $\begin{array}{c}\text { Don River } \\
\text { Main }\end{array}$ & $\begin{array}{c}\text { Don River } \\
\text { West }\end{array}$ & $\begin{array}{c}\text { Eastern } \\
\text { Beaches } \\
\text { Tunnel }\end{array}$ & $\begin{array}{c}\text { Etobicoke } \\
\text { Creek }\end{array}$ & $\begin{array}{c}\text { Highland } \\
\text { Creek }\end{array}$ & $\begin{array}{c}\text { Humber } \\
\text { River }\end{array}$ & $\begin{array}{c}\text { Inner } \\
\text { Harbour \& } \\
\text { Coatsworth } \\
\text { Cut } \\
\end{array}$ & $\begin{array}{l}\text { Lake } \\
\text { Ontario }\end{array}$ & $\begin{array}{c}\text { Massey } \\
\text { Creek }\end{array}$ & $\begin{array}{l}\text { Mimico } \\
\text { Creek }\end{array}$ & Rouge & waterfront & $\begin{array}{c}\text { Western } \\
\text { Beaches } \\
\text { Tunnel }\end{array}$ & Grand Total \\
\hline $\mathrm{C}$ & Commercial & 752.12 & 218.29 & 59.20 & 13.45 & 31.41 & 755.78 & 5.23 & \begin{tabular}{|l}
579.36 \\
\end{tabular} & 6.11 & 68.65 & 3.34 & 24.58 & 30.75 & 225.02 & $2,773.29$ \\
\hline $\mathrm{CBB}$ & Commercial Bigbox & & & & & 9.04 & & 272.20 & & 7.18 & & 72.85 & & & 4.20 & 365.47 \\
\hline $\mathrm{Cl}$ & Commercial Downtown & $1,467.47$ & 25.50 & 154.23 & & 0.05 & $1,197.84$ & 13.70 & 299.49 & 125.95 & 268.34 & 0.48 & 18.09 & & 91.15 & $3,662.28$ \\
\hline $\mathrm{CR}$ & commercial-industrial & 399.37 & 316.66 & 97.55 & 67.95 & 0.01 & 381.90 & 11.78 & 565.66 & 558.40 & 99.05 & 0.04 & 9.51 & 58.05 & 446.20 & $3,012.14$ \\
\hline CSM & commercial-residential & & 0.16 & & & 58.76 & & 271.10 & & 54.33 & & 146.45 & & & 0.15 & 530.95 \\
\hline EIS & Commercial Strip Mall & 26.97 & 52.45 & 2.68 & 2.16 & 73.30 & 16.25 & 819.05 & 168.19 & 2.43 & 13.70 & 46.51 & & & 21.22 & $1,244.90$ \\
\hline EIU & Educational/Institutional & & & & & & & 218.81 & & & & & & & & 218.81 \\
\hline $\mathrm{GC}$ & Golf Course & & & & & & & & & & & & 134.10 & & & 134.10 \\
\hline GS & Greenspace: parks & & & & & & 12.37 & & & & & & $1,261.43$ & & & $1,273.80$ \\
\hline 1 & industrial & 31.40 & & 30.65 & & & 119.72 & 0.02 & 22.63 & 85.75 & 26.48 & 0.07 & 2.16 & 131.88 & 36.93 & 487.70 \\
\hline $\mathrm{IBB}$ & Industrial Bigbox & & & & & 155.39 & & $1,408.56$ & & 1.99 & & 591.70 & & & 19.43 & $2,177.08$ \\
\hline $\mathrm{IN}$ & Resource-Industrial & 6.04 & 2.72 & & & 225.41 & 64.90 & & 50.96 & 0.43 & 12.72 & 0.25 & 524.40 & 0.99 & 4.78 & 893.61 \\
\hline IPR & Prestige Industrial & 0.11 & & & & 68.63 & & 286.29 & & 102.46 & & 327.69 & & & 1.00 & 786.19 \\
\hline $\mathrm{IR}$ & Resource-Industrial & 11.06 & & & & & 40.67 & 0.01 & & 0.46 & 18.74 & & & & 9.85 & 80.80 \\
\hline MIX & Mixed & & & & & & 1.56 & & & 38.97 & & 0.00 & 6.89 & & 26.97 & 74.39 \\
\hline OGC & Open Space -golf & & & & & & & 443.47 & & & & & & & 0.08 & 443.54 \\
\hline $\mathrm{OHC}$ & Open hydro corridor & & & & & & & 173.10 & & & & & & & & 173.10 \\
\hline $\mathrm{OPL}$ & Open Space/Park Land & 99.74 & 140.20 & 10.05 & 0.81 & 579.86 & 169.63 & $1,128.99$ & 55.10 & 30.35 & 147.20 & 669.48 & 28.97 & 27.76 & 59.83 & $3,147.99$ \\
\hline OVL & Open Valley Lands & & & & & & & 869.46 & & & & & & & & 869.46 \\
\hline PK & Park & & & & & & 9.73 & & & & & & 359.75 & 0.93 & & 370.41 \\
\hline $\mathrm{R}$ & residential & $10,054.55$ & $3,068.07$ & 275.18 & 467.40 & 173.60 & $7,266.20$ & 95.66 & $1,318.14$ & $1,236.84$ & $1,532.72$ & 7.96 & 251.71 & $1,164.11$ & $1,791.05$ & $28,703.18$ \\
\hline RES & residential, open area & & & & & 718.63 & & 7.27 & & 48.11 & & $1,896.03$ & & & & $2,670.04$ \\
\hline RHD & Residential High Density & & 1.44 & & & & & 585.45 & & & & 0.70 & & & 1.56 & 589.14 \\
\hline RHR & Residential High Rise & & 0.94 & & & & & 592.09 & & & & & & & 0.44 & 593.47 \\
\hline RLD & Residential Low Density & & 0.47 & & & & & $1,337.65$ & & & & 1.52 & & & 0.33 & $1,339.96$ \\
\hline RMD & Residential Medium Density & & 0.67 & & & & & $2,241.05$ & & & & 6.76 & & & 1.72 & $2,250.20$ \\
\hline RS & residential, open area & & & & & & 44.12 & & & & & & 492.33 & 3.65 & & 540.09 \\
\hline RT & commercial & & & & & & 2.80 & & & & & & 2.14 & & & 4.94 \\
\hline SC & Government-Institutional & & & & & & 1.18 & & & & & & 8.52 & & & 9.70 \\
\hline SPC & STP, Park, commercial-indus & & & & & & & 161.39 & & & & & & & & 161.39 \\
\hline TA & Government-Institutional, z & & & & & & & & & & & & 417.33 & & & 417.33 \\
\hline TAP & Downsview airport & 0.02 & & & & & & 174.78 & & & & & & & & 174.80 \\
\hline THC & Highway Corridors & 21.27 & 3.03 & & & 0.03 & 85.80 & $2,714.73$ & & 0.00 & & 97.27 & 5.38 & & 11.12 & $2,938.65$ \\
\hline TRY & roadways & & & & & & & 15.75 & & & & & & & & 15.75 \\
\hline W & Water & 0.00 & 13.33 & 0.03 & & 0.84 & 3.44 & 0.90 & 12.51 & 3.37 & 1.01 & & 0.05 & 9.63 & 1.17 & 46.28 \\
\hline Totals & & $12,870.12$ & $3,843.94$ & 629.58 & 551.77 & $2,094.94$ & $10,173.91$ & $13,848.50$ & $3,072.04$ & $2,303.13$ & $2,188.61$ & $3,869.11$ & $3,547.34$ & $1,427.75$ & $2,754.19$ & $63,174.95$ \\
\hline
\end{tabular}


Total Annual Runoff - Calibrated Analytical URF Model using Input From Banting et al. (2005)

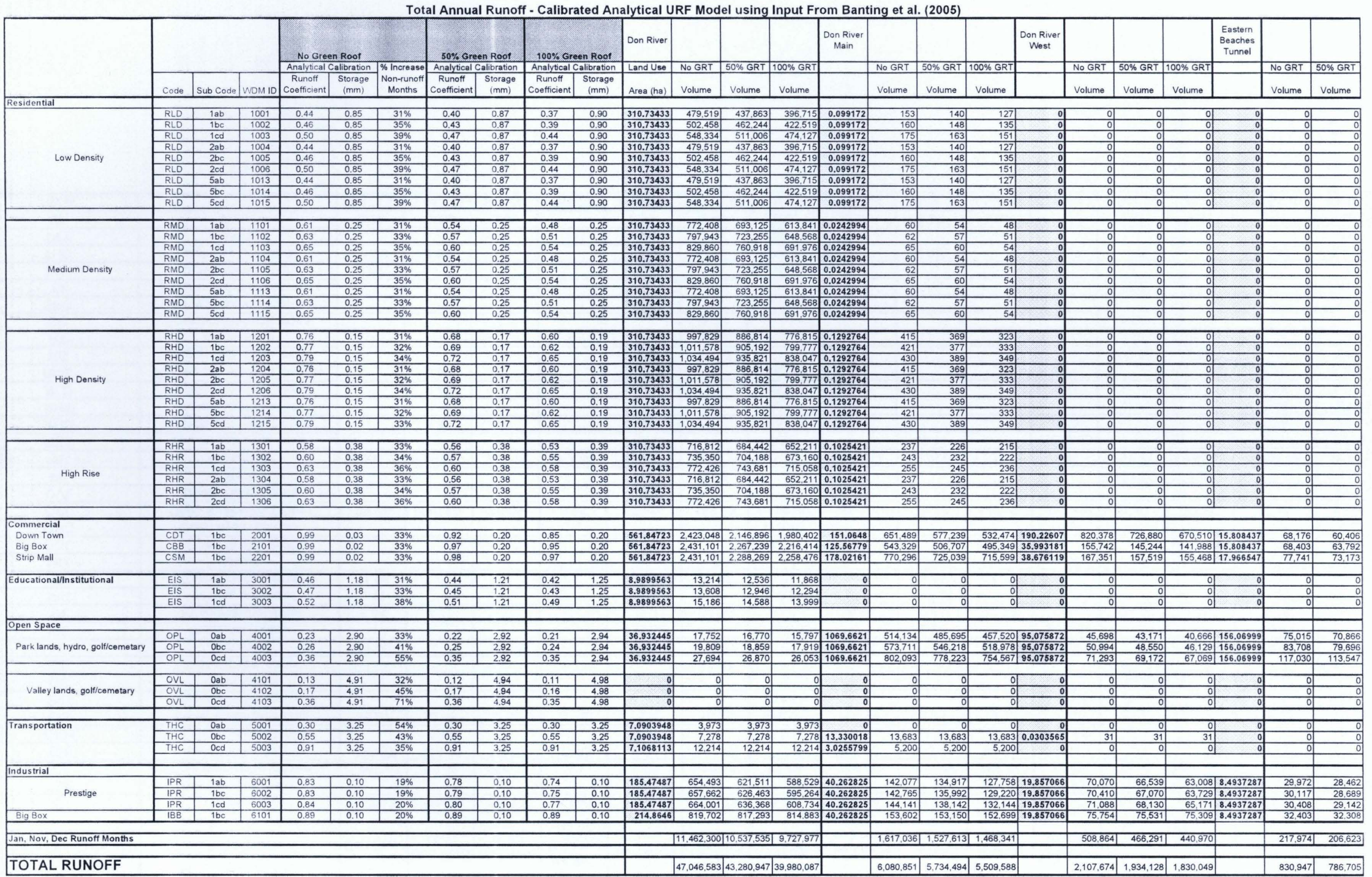


Total Annual Runoff - Calibrated Analytical URF Model using Input From Banting et al. (2005)

\begin{tabular}{|c|c|c|c|c|c|c|c|c|c|c|c|c|c|c|c|c|c|c|c|c|c|c|c|c|c|}
\hline & & & & \multirow{2}{*}{$100 \%$ GRT } & \multirow[t]{3}{*}{$\begin{array}{c}\text { Etobicoke } \\
\text { Creek }\end{array}$} & \multirow{3}{*}{$\begin{array}{l}\text { No GRT } \\
\text { Volume }\end{array}$} & \multirow{3}{*}{\begin{tabular}{|l}
$50 \%$ GRT \\
Volume \\
\end{tabular}} & \multirow{3}{*}{\begin{tabular}{|c|} 
\\
$100 \%$ GRT \\
Volume \\
\end{tabular}} & \multirow{3}{*}{\begin{tabular}{|l|}
$\begin{array}{c}\text { Humber } \\
\text { River }\end{array}$ \\
\end{tabular}} & \multirow{3}{*}{\begin{tabular}{|l|} 
No GRT \\
Volume \\
\end{tabular}} & \multirow{3}{*}{\begin{tabular}{|c|}
$50 \%$ GRT \\
Volume \\
\end{tabular}} & \multirow{3}{*}{\begin{tabular}{|c|} 
\\
$100 \%$ GRT \\
Volume \\
\end{tabular}} & \multirow{3}{*}{\begin{tabular}{|c|}
$\begin{array}{c}\text { Inner } \\
\text { Harbour } 8 \\
\text { Coatsworth } \\
\text { Cut }\end{array}$ \\
\\
\end{tabular}} & \multirow{3}{*}{\begin{tabular}{|l|} 
\\
No GRT \\
Volume \\
\end{tabular}} & \multirow{3}{*}{\begin{tabular}{|c|}
$50 \%$ GRT \\
Volume \\
\end{tabular}} & & $\begin{array}{l}\text { Lake } \\
\text { Ontario }\end{array}$ & & & & $\begin{array}{l}\text { Massey } \\
\text { Creek }\end{array}$ & & & & $\begin{array}{l}\text { Mimico } \\
\text { Creek }\end{array}$ \\
\hline & & & & & & & & & & & & & & & & $100 \%$ GRT & & No GRT & $50 \%$ GRT & $100 \%$ GRT & & No GRT & 50\% GRT & $100 \%$ GRT & \\
\hline & Code & Sub Code & WOM ID & \begin{tabular}{|l|} 
Volume \\
\end{tabular} & & & & & & & & & & & & Volume & & Volume & Volume & Volume & & Volume & Volume & Volume & \\
\hline & \begin{tabular}{|l|l|}
$R L D$ \\
$R L D$
\end{tabular} & \begin{tabular}{|l|}
$1 \mathrm{ab}$ \\
$1 \mathrm{bc}$ \\
\end{tabular} & \begin{tabular}{|l|}
1001 \\
1002 \\
\end{tabular} & & \begin{tabular}{|l|}
22.666961 \\
22.6669616 \\
\end{tabular} & \begin{tabular}{|l|}
34,979 \\
36,6522 \\
\end{tabular} & $\begin{array}{r}31,941 \\
33.719 \\
\end{array}$ & $\begin{array}{r}28.939 \\
30.821 \\
\end{array}$ & \begin{tabular}{|l|l|}
151.81519 \\
151.81519 \\
\end{tabular} & $\begin{array}{l}234,278 \\
245,485 \\
\end{array}$ & $\begin{array}{l}213,927 \\
225,838 \\
\end{array}$ & \begin{tabular}{|l|}
193,823 \\
206,430 \\
\end{tabular} & & & & & $\frac{2.2808643}{2.2808643}$ & & & \begin{tabular}{r|}
2,912 \\
3.101 \\
\end{tabular} & & & & & $\begin{array}{l}60.436441 \\
60.436441\end{array}$ \\
\hline & \begin{tabular}{|l|l|}
$R L D$ \\
$R L D$ \\
\end{tabular} & $\frac{1 \mathrm{~cd}}{2 \mathrm{ab}}$ & \begin{tabular}{|l|l|}
1003 \\
1004 \\
\end{tabular} & & \begin{tabular}{|l|}
22.666961 \\
22.666961 \\
\end{tabular} & \begin{tabular}{|l|}
39,999 \\
34,979 \\
\end{tabular} & $\begin{array}{r}37,276 \\
31,941 \\
\end{array}$ & \begin{tabular}{|r|}
34,586 \\
28,939 \\
\end{tabular} & $\begin{array}{l}151.81519 \\
151.81519 \\
\end{array}$ & \begin{tabular}{|l|}
267.899 \\
234.278 \\
\end{tabular} & \begin{tabular}{|l|}
249,662 \\
3 \\
213,927 \\
\end{tabular} & \begin{tabular}{|l|}
231,644 \\
193,823 \\
\end{tabular} & & & & & 2.2808643 & $\begin{array}{r}, 022 \\
3,52 \\
\end{array}$ & $\begin{array}{r}3,751 \\
3.214 \\
\end{array}$ & $\begin{array}{r}3.480 \\
2.912 \\
\end{array}$ & & & & & $\begin{array}{c}60.436441 \\
60.436441\end{array}$ \\
\hline Low Density & \begin{tabular}{|l|l|} 
RLD \\
RLD
\end{tabular} & $\frac{2 b c}{2 c d}$ & $\frac{1005}{1006}$ & & \begin{tabular}{|l|}
22.6669691 \\
22.666961 \\
\end{tabular} & \begin{tabular}{|l|l|}
36,652 \\
39.999 \\
\end{tabular} & $\begin{array}{r}33.719 \\
37.276 \\
\end{array}$ & \begin{tabular}{|l|}
30.821 \\
3.586 \\
\end{tabular} & $\begin{array}{l}\frac{151.81519}{5151.1519} \\
1519\end{array}$ & $\begin{array}{l}245.485 \\
267799 \\
\end{array}$ & 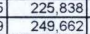 & \begin{tabular}{|l|}
206.430 \\
231.444 \\
\end{tabular} & & 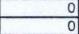 & & 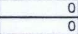 & $\frac{2.2808643}{2.2808643}$ & $\begin{array}{l}3.68 \\
4.02 \\
\end{array}$ & $\begin{array}{r}3,393 \\
3,751 \\
\end{array}$ & $\begin{array}{l}3.101 \\
3.480 \\
\end{array}$ & & & & & $\frac{60.436441}{600.46441}$ \\
\hline & RLD & $5 a b$ & 1013 & & 22.666961 & 34,979 & 31,941 & \begin{tabular}{|l|}
28,939 \\
\end{tabular} & 151.81515 & 234.278 & \begin{tabular}{|l|}
213,927 \\
\end{tabular} & 193.823 & & & & & 2.2808643 & & 3.214 & 2.912 & & & & & 60.436441 \\
\hline & $\begin{array}{l}\text { RLD } \\
R L \\
\end{array}$ & \begin{tabular}{|l}
$5 \mathrm{bc}$ \\
$5 \mathrm{~cd}$ \\
\end{tabular} & \begin{tabular}{|l|}
1014 \\
1015 \\
\end{tabular} & & 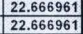 & $\begin{array}{r}36,62 \\
39,999 \\
\end{array}$ & $\begin{array}{r}33,719 \\
37.276 \\
\end{array}$ & $\begin{array}{l}33.821 \\
34.586 \\
\end{array}$ & 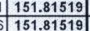 & 245.4895 & $\begin{array}{l}225,838 \\
24,962 \\
\end{array}$ & $\begin{array}{l}206.430 \\
23.644 \\
\end{array}$ & & & & & $\mid \frac{2.28086443}{2.2888643}$ & $\begin{array}{l}3.6 \\
4.0\end{array}$ & $\begin{array}{r}3,393 \\
3,751 \\
\end{array}$ & $\begin{array}{l}3,101 \\
3,480 \\
\end{array}$ & & & & & $\frac{60.436441}{60.46441}$ \\
\hline & RMD & $1 \mathrm{ab}$ & 1101 & & 22.666961 & 56,344 & 50.5610 & 44,778 & B.252.1924 & 626.88 & 562.54 & 498,195 & & & & & 2.2808643 & 5,67 & $5,08 \mathrm{~s}$ & 4,506 & & & & & \\
\hline & 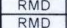 & $\frac{1 b c}{1 c d}$ & $\frac{1102}{1103}$ & & & \begin{tabular}{|l|l|l}
58.207 \\
60535
\end{tabular} & $\begin{array}{r}52.759 \\
55506 \\
\end{array}$ & $\begin{array}{r}47.311 \\
50477 \\
\end{array}$ & $\begin{array}{l}1 \frac{252.19249}{7252.19249} \\
7252\end{array}$ & $\frac{647.611}{673516}$ & $\begin{array}{l}586,995 \\
617562 \\
\end{array}$ & \begin{tabular}{|l}
526.379 \\
561.09 \\
\end{tabular} & & & & & 2.2808643 & 5.85 & $\begin{array}{l}5.305 \\
5.585 \\
\end{array}$ & $\begin{array}{l}4.761 \\
5.079\end{array}$ & & & & & 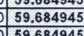 \\
\hline & RMD & $2 a b$ & 1104 & & \begin{tabular}{|l|}
22.6669610 \\
\end{tabular} & 56,344 & $\begin{array}{l}50,5601 \\
561\end{array}$ & $\frac{0.476}{44.778}$ & 3252.19249 & $\frac{01.030}{626.888}$ & \begin{tabular}{|l|}
562,541 \\
\end{tabular} & \begin{tabular}{|l|l|}
591,05 & \\
498,195 &
\end{tabular} & & & & & $\frac{2.2880643}{2.2808643}$ & $\begin{array}{l}0,05 \\
5,67 \\
\end{array}$ & $\begin{array}{l}5,585 \\
5,088 \\
\end{array}$ & $\begin{array}{l}5.079 \\
4.506 \\
\end{array}$ & & & & & $\frac{59.684945}{5.984445}$ \\
\hline Medium Density & \begin{tabular}{|l|l|} 
RMD \\
RMD
\end{tabular} & $\frac{2 \mathrm{bc}}{2 \mathrm{~cd}}$ & $\frac{1105}{1106}$ & & $\begin{array}{l}22.666961 \\
22.666961 \\
\end{array}$ & $\begin{array}{l}58,207 \\
60535 \\
\end{array}$ & 52.759 & $\begin{array}{l}47.311 \\
5.477 \\
\end{array}$ & $\begin{array}{l}1252.19249 \\
25219249\end{array}$ & $\begin{array}{l}647.611 \\
673516 \\
756\end{array}$ & \begin{tabular}{|l|}
586,995 \\
61752 \\
\end{tabular} & \begin{tabular}{|l}
526.379 \\
561.699 \\
\end{tabular} & & - & & & $\begin{array}{l}2.2808643 \\
2.2880643 \\
\end{array}$ & $\begin{array}{l}5.85 \\
6.09 \\
\end{array}$ & $\begin{array}{l}5,309 \\
5.585 \\
\end{array}$ & $\begin{array}{l}4.761 \\
.5701 \\
\end{array}$ & & & & & $\begin{array}{l}59.644945 \\
5.984945\end{array}$ \\
\hline & RMD & $5 a b$ & 1113 & & \begin{tabular}{|l|l|}
22.666961 \\
\end{tabular} & 56,344 & 50.561 & 44.778 & $\begin{array}{l}852.19249 \\
\end{array}$ & 626.888 & 562,541 & 498.195 & & & & & 2.2808643 & 5,67 & 5,088 & 4.506 & & & & & $\begin{array}{l}\frac{59664445}{59.684945} \\
5\end{array}$ \\
\hline & $\begin{array}{l}\text { RMD } \\
\text { RMD } \\
\end{array}$ & $\begin{array}{l}5 \mathrm{bc} \\
5 \mathrm{~cd}\end{array}$ & $\frac{1114}{1115}$ & & \begin{tabular}{|l}
22.666961 \\
22.6656911 \\
\end{tabular} & $\begin{array}{l}58.207 \\
60.535 \\
\end{array}$ & 52,759 & \begin{tabular}{|l|l}
$\frac{47.311}{50.477}$ \\
\end{tabular} & 252.19249 & $\begin{array}{l}647,611 \\
673.516 \\
\end{array}$ & \begin{tabular}{|l|l|}
586,9955 \\
671562 \\
\end{tabular} & \begin{tabular}{|l|}
526,379 \\
561.699 \\
\end{tabular} & & & & & $\frac{2.2808644}{2.2808643}$ & $\frac{5,85}{609}$ & $\begin{array}{r}5,309 \\
5855\end{array}$ & \begin{tabular}{|l|}
4.761 \\
5.079 \\
\end{tabular} & & & & & 59.6849455 \\
\hline & RHD & $19 \mathrm{~b}$ & 120 & & 22.66961 & 72789 & & काल & (180 & 219127 & 194744 & 170 & & & & & 20 & & & & & & & & \\
\hline & RHD & $1 \mathrm{bc}$ & 1202 & 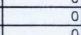 & 22.6669611 & 73.791 & $\begin{array}{l}364.031 \\
6.0369\end{array}$ & 58.341 & 168.237018 & 222.142 & 198.779 & $\begin{array}{l}175.630 \\
\end{array}$ & & - & & & $\frac{2.2000643}{2.280843}$ & $\begin{array}{l}7,42 \\
7.42 \\
\end{array}$ & $\frac{0.044}{6.644}$ & 5.871 & & & & & 59.684945 \\
\hline & & $\frac{1 c d}{2 a b}$ & $\frac{1203}{1204}$ & & & $\begin{array}{r}75,463 \\
72788 \\
\end{array}$ & & $\frac{6.1133}{56.666}$ & & $\frac{227,17}{219122}$ & & \begin{tabular}{|l|}
184.03 \\
170.58 \\
\end{tabular} & & & & & & $\begin{array}{r}7.59 \\
7.32 \\
\end{array}$ & & $\frac{6.151}{5.702}$ & & & & & \begin{tabular}{|l|l|}
59.684945 \\
59.689445
\end{tabular} \\
\hline High Density & RHD & $2 \mathrm{bc}$ & $\frac{1204}{1205}$ & & 22.666961 & 73,791 & 66.031 & 58.341 & 168.237018 & 222,1427 & 198,779 & 175,63 & & & & & 2.2808643 & 7.424 & & 5.8711 & & & & & $\frac{54.048440}{59.684945}$ \\
\hline & RHD & $20 d$ & $\frac{1206}{123}$ & & $\begin{array}{l}22.666961 \\
2006091\end{array}$ & 75,463 & 68,265 & $\begin{array}{l}61.133 \\
5.663\end{array}$ & 68.237018 & 227,174 & \begin{tabular}{|l|}
205,506 \\
\end{tabular} & \begin{tabular}{|l|l|}
184.035 \\
170509
\end{tabular} & & 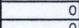 & & & $\frac{2.2808643}{2.2003010}$ & $\begin{array}{r}7.59 \\
720 \\
\end{array}$ & 6,869 & $\begin{array}{l}6.151 \\
.502\end{array}$ & & & & & $\begin{array}{l}59.684945 \\
5.98495\end{array}$ \\
\hline & $\begin{array}{l}\text { RHD } \\
\text { RHD }\end{array}$ & $\frac{5 a b}{5 b c}$ & 1214 & & 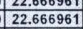 & $\begin{array}{l}1,2,86 \\
73,791 \\
\end{array}$ & 66.031 & $\begin{array}{l}56.666 \\
58,341 \\
\end{array}$ & $\begin{array}{l}568.23018 \\
168.237018 \\
\end{array}$ & $\frac{219,12}{222,142}$ & \begin{tabular}{|l|}
198,779 \\
\end{tabular} & 175,630 & - & 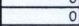 & & & 2.2808643 & $\frac{2,14}{7.42}$ & $\frac{3.044}{6.644}>0$ & 5.071 & & - & & & 599.6844945 \\
\hline & RHD & $5 \mathrm{~cd}$ & 1215 & & 22.666961 & 75,463 & 68,265 & 61,133 & 368.237018 & 227,17 & 205,506 & 184,035 & & & & & 2.2808643 & & 6.869 & 6,151 & & & & & (59.684945 \\
\hline & RHR & $1 \mathrm{ab}$ & 1301 & & 22.666961 & 52,289 & 49,928 & 47.576 & 6 101.86864 & 234,994 & 224,382 & 213,816 & & & & & 2.2808643 & 5.26 & 5,024 & 4.787 & & & & & 59.937918 \\
\hline & \begin{tabular}{|l|l|} 
RHR \\
PHP
\end{tabular} & $1 \mathrm{bc}$ & $\frac{1302}{102}$ & & 22.666961 & 53,641 & $\begin{array}{r}51,368 \\
5.2020\end{array}$ & $\begin{array}{l}49,105 \\
52161\end{array}$ & $5101.86864 \mid$ & \begin{tabular}{|l|l|}
241,071 \\
253220
\end{tabular} & \begin{tabular}{|l|l|}
230,855 \\
203007
\end{tabular} & \begin{tabular}{|l|}
220.683 \\
234.419
\end{tabular} & o| & 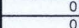 & & & 2.2808643 & 5,398 & $\begin{array}{r}5,169 \\
5.450\end{array}$ & 4,941 & & & & & $\frac{59.937918}{5.973919}$ \\
\hline High Rise & \begin{tabular}{|l|l|} 
RHR \\
\end{tabular} & $\frac{1 c a}{2 a b}$ & $\frac{1303}{1304}$ & & \begin{tabular}{|l|}
22.6669661 \\
22.666961 \\
\end{tabular} & $\begin{array}{r}5,364 \\
52.289 \\
\end{array}$ & $\begin{aligned} 54,49 \\
49,928\end{aligned}$ & \begin{tabular}{|l|l|}
52.1676 \\
47.576 \\
\end{tabular} & | & $\begin{array}{l}253,224 \\
234,994 \\
\end{array}$ & $\begin{array}{lll}4 & 2.4 .38 \\
& 224382\end{array}$ & 213.816 & 6 & 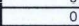 & & - & \begin{tabular}{|l|l|}
2.28006843 \\
2.2808643
\end{tabular} & 5.262 & 5.024 & $\begin{array}{r}5,249 \\
4.787 \\
\end{array}$ & & & & & 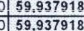 \\
\hline & \begin{tabular}{|l|l|} 
RHR \\
RHR
\end{tabular} & $2 \mathrm{bc}$ & \begin{tabular}{|l|l|}
1305 \\
1306
\end{tabular} & & \begin{tabular}{|l|l|}
22.666961 \\
2266961
\end{tabular} & $\begin{array}{l}53,641 \\
563646\end{array}$ & $\begin{aligned} 51,368 \\
54249\end{aligned}$ & \begin{tabular}{|l|}
49,105 \\
52161 \\
\end{tabular} & $5 \mid 101.86864$ & \begin{tabular}{|l|l|}
241,07 \\
25222 \\
\end{tabular} & \begin{tabular}{l|l|}
1 & 230,855 \\
& 243802 \\
\end{tabular} & \begin{tabular}{|l|l|}
220,683 \\
23449 \\
\end{tabular} & & 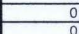 & & & $\begin{array}{l}2.2808643 \\
2.2880643 \\
\end{array}$ & $5, \frac{396}{5670}$ & $\begin{array}{r}5.169 \\
5.55 \\
\end{array}$ & $\begin{array}{r}4.941 \\
5.501\end{array}$ & & & & & \\
\hline & & & & & & & & & & & & & & & & & & & & & & & & & \\
\hline $\begin{array}{l}\text { Commercial } \\
\text { Down Town }\end{array}$ & & & & & & & & & & & & & & & & & & & & & & & & & \\
\hline & $\frac{C D T}{C B B}$ & $\frac{1 b c}{1 b c}$ & $\frac{2001}{2101}$ & $\frac{55.722}{6.362}$ & 20.308417 & $\begin{array}{r}87,58 \\
126798 \\
\end{array}$ & $\frac{77.601}{118251}$ & $\frac{71.583}{11500}$ & 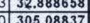 & $\frac{141,83}{132011}$ & $\frac{125,672}{1231132}$ & $\frac{15.926}{120534}$ & $\frac{5566.8847}{4287965}$ & $\frac{2,531,04}{1.2356}$ & $\frac{2.242,58}{1.1574}-10$ & 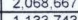 & & $\frac{92.36}{9.36}>20$ & $\frac{879.26}{8792}>0$ & $\frac{811.08}{81.08}>0$ & & $\frac{1.027}{1.70}$ & 175. & 1.,084 & \\
\hline Strip Mall & \begin{tabular}{|l}
$\operatorname{cs} M$ \\
\end{tabular} & $1 \mathrm{cc}$ & 2201 & $\frac{0.5021}{72.221}$ & 903.557726 & 404.822 & 381.038 & 376.077 & \begin{tabular}{|l|l|} 
& 303.98413 \\
\end{tabular} & $\frac{1,203,11}{1,315,33}$ & $\frac{1,2039.152}{1,238.055}$ & 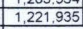 & $\begin{array}{c}455.5864 \\
\end{array}$ & 1.,971.31 & $\frac{1.1555,45}{1.85}$ & $\frac{1,150,1,49}{1,831,33}$ & 10.5879 & 4661.21 & 434.1 & $\frac{428.21}{428.45}-1$ & 53.08958 & 229 & & $215>>>3$ & 72.04177. $\mathrm{Y}>\mathrm{C}$ \\
\hline Educational//nstitutional & EIS & $1 \mathrm{ab}$ & 3001 & & & & & & 0 0 345.95227. & $508.49:$ & 94882,399 & 456.717 & & & & & & & & & & & & & \\
\hline & \begin{tabular}{|l|l|} 
EIS \\
EIS
\end{tabular} & \begin{tabular}{|l|l|}
$1 b c$ \\
$1 c d$
\end{tabular} & \begin{tabular}{|l|}
3002 \\
3003 \\
\end{tabular} & & s & 5 & 0 & $=$ & 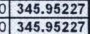 & \begin{tabular}{|l|l|}
523,678 \\
554.39
\end{tabular} & \begin{tabular}{l|l}
8 & 498,192 \\
4 & 561,365 \\
\end{tabular} & \begin{tabular}{|l|l|}
473.112 \\
538659 \\
\end{tabular} & & & & & & & & & & & & & \\
\hline & & & & & & & & & & & & & & & & & & & & & & & & & \\
\hline Open Space & & & & & & & & & & & & & & & & & & & & & & & & & \\
\hline Park lands, hydro, golfflcemetary & $\frac{O P L}{O P L}$ & $\frac{a b}{0 \text { obc }}$ & $\frac{4001}{4002}$ & $\frac{6.655}{75.722}$ & $251.1530 \mathrm{c}$ & $\frac{120,71}{13470}$ & $\frac{144.040}{1285250}$ & $\frac{107,424}{112854}$ & $\begin{array}{l}4 \frac{513.27894}{4} 5137894 \\
41378\end{array}$ & 246,706 & 233,061 & $\frac{219.542}{24033}$ & $\frac{2457.7467}{3}$ & 220.0 & $\frac{207.84}{2374}$ & $\frac{195,78}{22208}$ & 43553.36604 & 209.265 & $\frac{197.69}{2032}>20$ & $\frac{186,22}{2124}+2$ & 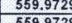 & 年 & 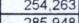 & $\frac{239.5}{27.5}$ & 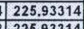 \\
\hline & \begin{tabular}{|l|l|}
$O P L$ \\
\end{tabular} & ocd & 4003 & 110,096 & 251.15309 & 188.325 & 182.724 & 177,170 & 0) 513.27894 & 384,884 & \begin{tabular}{|l|l|}
5 & 373,432 \\
\end{tabular} & \begin{tabular}{|l|}
362.080 \\
\end{tabular} & 457.7467 & 343.24 & 33 & 322. & 435.38600 & 326.47 & 316.76 & 307,133 & 559.97 & 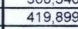 & & & 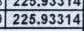 \\
\hline & OVVL & Oab & 4101 & & & 然 & 0 & 0 & $0 \mid 363.72974$ & 55.992 & \begin{tabular}{|l|l|}
4 & 52.057 \\
\end{tabular} & 48.184 & & 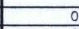 & -1 & 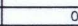 & & -1 & & & & & & & \\
\hline Valley lands, golicemetary & \begin{tabular}{|l|l|l|l|l|l|} 
OVL \\
\end{tabular} & $\frac{O b c}{0 c d}$ & \begin{tabular}{|l|l|}
4402 \\
103 \\
\end{tabular} & & & & & & $\begin{array}{l}0.363 .79974 \\
0 \mid 363.72974 \\
0\end{array}$ & $\begin{array}{l}77.57 \\
161,73\end{array}$ & \begin{tabular}{l|r|} 
& 73,695 \\
1 & 158,086
\end{tabular} & \begin{tabular}{|r|}
69.879 \\
154.491 \\
\end{tabular} & & & & & & & & & & & & & \\
\hline & & & & & & & & & & & & & & & & & & & & & & & & & \\
\hline Transportation & \begin{tabular}{|l|l|} 
THC \\
THC
\end{tabular} & $\begin{array}{l}a b b \\
0 b c \\
\end{array}$ & $\begin{array}{l}5001 \\
502\end{array}$ & & 0 & & & 860 & $\begin{array}{l}0904.9108 \\
0920.6561 \\
926\end{array}$ & \begin{tabular}{|l}
507,04 \\
945.04 \\
\end{tabular} & 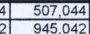 & \begin{tabular}{|l|}
507.044 \\
9450.042
\end{tabular} & $\begin{array}{l}4 \\
\begin{array}{l}4 \\
212.510244\end{array}\end{array}$ & 12,841 & 12841 & $\frac{\mathrm{c}}{12841}$ & $\frac{0}{3.3670375}$ & 3456 & 3.56 & 345 & 1.008182 & $\frac{\mathrm{c}}{1035}$ & & 10 & \\
\hline & THC & ocd & 5003 & & 0.0332561 & & & & 7079.6953 & \begin{tabular}{|l|l|l|}
1.855 .61 \\
\end{tabular} & \begin{tabular}{|l|l|}
0 & 1.855 .610 \\
\end{tabular} & $1,855.610$ & & & & & 0 & & & & & & & & 97.2748 \\
\hline |ndustrial & & & & & & & & & & & & & & & & & & & & & & & & & \\
\hline & IPR & $1 \mathrm{ab}$ & 6001 & 26,951 & 79.229611 & 279.58 & & 251,403 & & 275.99 & $\begin{array}{l}0.02 .082 \\
0.0\end{array}$ & 248.173 & $3 \longdiv { 8 9 . 1 }$ & 314,429 & 298.58 & 282.739 & 125. & 443.27 & 420,933 & 398,595 & & & & & 109.31348 \\
\hline Prestige & 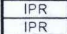 & $\frac{1 b c}{10 d}$ & $\frac{6002}{6003}$ & \begin{tabular}{|l|}
27.260 \\
27877 \\
\end{tabular} & 79.229611 & $\begin{array}{ll}280,934 \\
233.64\end{array}$ & \begin{tabular}{|l|l|}
267.607 \\
271.838
\end{tabular} & \begin{tabular}{|l|l}
254.280 \\
260.034
\end{tabular} & $\begin{array}{l}078.211896 \\
478.218966\end{array}$ & $\begin{array}{ll}277.32 \\
279.99\end{array}$ & \begin{tabular}{l|l}
6 & 264,170 \\
9 & 268.346 \\
\end{tabular} & 251.014 & 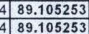 & \begin{tabular}{|c|}
315.952 \\
318,997 \\
\end{tabular} & \begin{tabular}{|l|l}
300,963 \\
3057722 \\
\end{tabular} & $\begin{aligned} 285.975 \\
29246\end{aligned}$ & $\frac{125.6171}{125.6171}$ & $\frac{445.41}{449.71}$ & $\frac{424.28}{430.99}$ & $\frac{403.15}{412.27}$ & & & & & 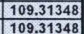 \\
\hline Big Box & IBB & $1 \mathrm{bc}$ & 6101 & 32,213 & 211.74413 & $\frac{2007.79}{809}$ & 805.423 & 803.049 & a 76.2111896 & 2988,37 & \begin{tabular}{l|l|}
6 & 290,340 \\
6
\end{tabular} & 296.622 & $\begin{array}{l}4 \\
289.105253 \\
29.1053 \\
\end{array}$ & \begin{tabular}{|l|l|}
339.934 \\
339.93
\end{tabular} & \begin{tabular}{|l|l|}
330,1225 \\
338,935 \\
\end{tabular} & \begin{tabular}{|l|l|}
337.436 \\
3376
\end{tabular} & 93.455494 & $\frac{449.13}{356.53}$ & 355.482 & \begin{tabular}{|l|l|}
454.41 \\
354. \\
\end{tabular} & & & & & 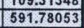 \\
\hline Jan, Nov, Dec Runoff Months & & & - & 198.573 & & $1,343,32$ & 1.261 .423 & $1,189.364$ & & 7.460 .26 & $8 \longdiv { 7 , 0 1 8 , 6 6 7 }$ & 6.621 .552 & & $2,513.301$ & $2,329.006$ & 2.231 .901 & & $1,376.15$ & 1.287.915 & 1.229 .108 & & 1.013 .992 & 938.047 & 888.255 & \\
\hline 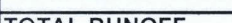 & & & & - & & & & & & & & & & & & & & & & & & & & & \\
\hline TOTAL RUNOFF & & & & 755,751 & & $5,909,98:$ & $5,567,935$ & $5,265,592$ & & $29,046,62$ & $7 / 27,272,451$ & $25,677,706$ & & $10,370,143$ & $9,618,491$ & $9,218,369$ & & $5,965,37$. & $5,592,902$ & $5,339,021$ & & 3,731, & 3,437,738| & 3.248,985 & \\
\hline
\end{tabular}


Total Annual Runoff - Calibrated Analytical URF Model using Input From Banting et al. (2005)

\begin{tabular}{|c|c|c|c|c|c|c|c|c|c|c|c|c|c|c|c|c|c|c|}
\hline & & & & & & & rouge & & & & waterfront & & & & \begin{tabular}{|c|} 
Western \\
Beaches \\
Tunnel \\
\end{tabular} & & & \\
\hline & & & & No GRT & $50 \%$ GRT & $100 \%$ GRT & & No GRT & $50 \%$ GRT & $100 \%$ GRT & & No GRT & $50 \%$ GRT & $100 \%$ GRT & & No GRT & $50 \%$ GRT & $100 \%$ GRT \\
\hline & Code & Sub code & WOM IO & Volume & Volume & Volume & & Volume & Volume & Volume & & Volume & Volume & Volume & & Volume & Volume & Volume \\
\hline \multirow{5}{*}{ Low Density } & $\begin{array}{l}R L D \\
R L D \\
\end{array}$ & $\begin{array}{l}\mathrm{ab} \\
\mathrm{bcc} \\
\end{array}$ & $\frac{1001}{1002}$ & $\begin{array}{l}93.264 \\
97.726 \\
\end{array}$ & $\begin{array}{l}85,162 \\
89.904 \\
\end{array}$ & $\begin{array}{l}77.159 \\
82.178 \\
\end{array}$ & \begin{tabular}{|l}
0.0323749 \\
0.0323749 \\
\end{tabular} & 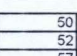 & & & & ב- & & & \begin{tabular}{|l|}
0.2165496 \\
0.2165496 \\
\end{tabular} & & & \\
\hline & $\begin{array}{ll}R L D \\
R L D \\
\end{array}$ & $\frac{1 \mathrm{~cd}}{2 \mathrm{ab}}$ & $\frac{1003}{1004}$ & $\begin{array}{r}106,649 \\
93.264 \\
\end{array}$ & $\begin{array}{r}99,388 \\
85,162 \\
\end{array}$ & $\begin{array}{l}92,216 \\
77,159 \\
\end{array}$ & \begin{tabular}{|l|}
0.0323749 \\
0.0323749 \\
\end{tabular} & 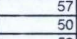 & & $\begin{array}{l}49 \\
41 \\
\end{array}$ & & 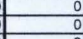 & & & $\begin{array}{l}0.2165496 \\
0.2165496 \\
\end{array}$ & & & \\
\hline & $\begin{array}{l}\text { RLD } \\
R L D\end{array}$ & $\frac{2 b c}{2 c d}$ & $\frac{1005}{1006}$ & $\begin{array}{c}\frac{97.726}{106.649} \\
\end{array}$ & $\begin{array}{r}89,904 \\
99.388 \\
\end{array}$ & $\begin{array}{r}82.78 \\
92.216 \\
\end{array}$ & \begin{tabular}{|l|l|}
0.03323749 \\
0.0323749
\end{tabular} & - & & $\frac{44}{49}$ & & - & & & $\begin{array}{l}0.21256496 \\
0 \\
0.2165496\end{array}$ & & & \\
\hline & RLD & $5 \mathrm{ab}$ & 1013 & $\begin{array}{r}93.264 \\
972724 \\
7\end{array}$ & 85.162 & $\begin{array}{c}5.7110 \\
78.159 \\
\end{array}$ & 0.0323774 & ${ }_{-}$ & & & & 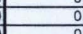 & & & \begin{tabular}{|l|l|}
0.21654969 \\
\end{tabular} & & & \\
\hline & RLD & $\frac{5 b c}{5 c d}$ & $\frac{1014}{1015}$ & $\frac{97.76}{106.649}$ & $\begin{array}{r}89,904 \\
99.388 \\
\end{array}$ & $\begin{array}{l}8.2178 \\
92.216 \\
\end{array}$ & $\begin{array}{l}0.03323749 \\
0.0 .0323749\end{array}$ & 5 & & & & & & & $\begin{array}{l}0.2165496 \\
0.2165496\end{array}$ & & & \\
\hline \multirow{6}{*}{ Medium Den } & \begin{tabular}{|l|} 
RMD \\
RMD \\
\end{tabular} & $\frac{1 \mathrm{ab}}{1 \mathrm{bc}}$ & $\begin{array}{l}\frac{1101}{1102} \\
102\end{array}$ & $\begin{array}{l}\frac{148,362}{1532266} \\
\end{array}$ & $\begin{array}{l}133,133 \\
138,921\end{array}$ & $\begin{array}{l}117.905 \\
12.575 \\
\end{array}$ & $\begin{array}{l}54.735336 \\
544.75356\end{array}$ & $\frac{136,05}{14.55}$ & $\frac{122,093}{12700}$ & $\frac{\mid 108,127}{114,244}$ & $\begin{array}{l}0.4052449 \\
0.40524499\end{array}$ & $\frac{1,007}{1,041}$ & & $\frac{801}{846}$ & $\frac{10.0259196}{6}$ & & & \\
\hline & RMD & $\frac{10 c}{10 d}$ & $\frac{1102}{1103}$ & $\begin{array}{l}\frac{1533.26}{159.397} \\
\end{array}$ & $\begin{array}{r}\frac{138.821}{146.155} \\
\end{array}$ & 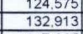 & \begin{tabular}{|l|l|}
54.73535356 \\
\end{tabular} & $\begin{array}{r}40.55 \\
146,177 \\
\end{array}$ & $\frac{127,400}{134,034}$ & $\frac{114.244}{121.890}$ & $\begin{array}{l}0.4052449 \\
0.4052449\end{array}$ & $\frac{1.06}{1.08}$ & & & $\frac{0.0259196}{0.0259196}$ & & & \\
\hline & $\begin{array}{l}\text { RMD } \\
\text { RMD }\end{array}$ & $\frac{2 \mathrm{ab}}{2 \mathrm{bc}}$ & $\frac{1104}{1105}$ & $\frac{146.362}{153.266}$ & $\begin{array}{r}133,33 \\
138,921 \\
\end{array}$ & \begin{tabular}{|l|}
1177905 \\
124.575 \\
\end{tabular} & \begin{tabular}{|l|l|}
54.753356 \\
54.735356
\end{tabular} & $\begin{array}{r}136.059 \\
140.556 \\
\end{array}$ & $\frac{122,09}{12700}$ & $\begin{array}{l}108,127 \\
114,244\end{array}$ & $\begin{array}{l}0.4002449 \\
0.4052449 \\
0.0\end{array}$ & $\begin{array}{l}1,007 \\
1,041\end{array}$ & & $\frac{801}{846}$ & $\frac{10.0255196}{6}$ & & & \\
\hline & RMD & 2 cd & $\begin{array}{l}1106 \\
113\end{array}$ & $\begin{array}{l}159,397 \\
\end{array}$ & 146.155 & \begin{tabular}{|l}
132.913 \\
\end{tabular} & 54.735356 & 146.179 & $134,03$. & 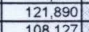 & $\begin{array}{l}0.4052449 \\
.0 .249\end{array}$ & $\begin{array}{l}1,082 \\
\end{array}$ & & & 0.0259196 & & & \\
\hline & RMD & $\frac{5 \mathrm{ab}}{5 \mathrm{bc}}$ & $\frac{1113}{1114}$ & $\begin{array}{l}148,362 \\
153266 \\
\end{array}$ & $\begin{array}{r}133,133 \\
138921 \\
138\end{array}$ & $\begin{array}{r}117.905 \\
12575 \\
1255\end{array}$ & 54.735356 & $\frac{136.055}{110.55}$ & $\frac{122,09}{17240}$ & $\begin{array}{l}108,127 \\
114244\end{array}$ & 0.4052449 & $\begin{array}{r}1,007 \\
1041\end{array}$ & & & \begin{tabular}{|l|}
0.0255196 \\
0.025919
\end{tabular} & & & \\
\hline & RMD & $50 c$ & 1115 & $\begin{array}{l}1539.300 \\
159,397 \\
\end{array}$ & 146,155 & 132.913 & 54.7353556 & $\frac{140.53}{146.17}$ & $\begin{array}{r}134,40 \\
134,03 \\
\end{array}$ & & 0.4052449 & & & & 20.0259196 & & & \\
\hline \multirow{7}{*}{ High Density } & RHD & & & 191,660 & $\begin{array}{l}170,337 \\
\end{array}$ & 149,208 & 0.0323749 & & & & & & & & 0.0750948 & & & \\
\hline & RHD & $1 \mathrm{bc}$ & & & $\begin{array}{r}173.867 \\
\end{array}$ & & & & & & & & & & 0.0750948 & & & \\
\hline & $\begin{array}{l}\text { RHD } \\
\text { RHD }\end{array}$ & $\frac{1 \mathrm{~cd}}{2 \mathrm{ab}}$ & $\frac{1203}{1204}$ & $\frac{198,703}{119600}$ & $\begin{array}{r}179,750 \\
177337 \\
\end{array}$ & \begin{tabular}{|l|l|}
160.970 \\
149208 \\
\end{tabular} & $\begin{array}{l}0.0323749 \\
0.032374\end{array}$ & & & & & -1 & - & & $\frac{0}{0.0750948}$ & & & \\
\hline & RHD & $\frac{2 \mathrm{ab}}{2 \mathrm{bc}}$ & $\begin{array}{l}1204 \\
1205 \\
\end{array}$ & $\begin{array}{l}194,301 \\
\end{array}$ & 173,867 & \begin{tabular}{|l|}
153,619 \\
\end{tabular} & 0.0323749 & $\begin{array}{l}104 \\
105 \\
\end{array}$ & & & 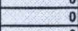 & 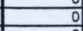 & & & 0.0750948 & & 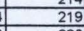 & \\
\hline & $\frac{\text { RHD }}{\text { RHD }}$ & $\frac{2 c d}{5 a b}$ & $\frac{1206}{1213}$ & $\frac{198,7.73}{1960}$ & $\begin{array}{r}179,750 \\
170,337 \\
\end{array}$ & \begin{tabular}{|l|}
160.970 \\
149.208 \\
\end{tabular} & $\begin{array}{l}0.03233749 \\
0.0323749\end{array}$ & & & & & & & & \begin{tabular}{|l|}
0.0750948 \\
0.075098
\end{tabular} & & & \\
\hline & & $5 \mathrm{bc}$ & & & & & & & & & & & & & & & & \\
\hline & RHD & $5 \mathrm{~cd}$ & $\frac{1215}{1215}$ & 198,70 & 179,750 & 160,970 & 0.0323749 & & & & & & & & 0.0750948 & & & \\
\hline \multirow{5}{*}{ High Rise } & RHR & $1 \mathrm{ab}$ & 1301 & 138,267 & 132,023 & 125,806 & 0.0323749 & & & & & & & & 0.0801726 & & & \\
\hline & $\begin{array}{l}R H R \\
R H R\end{array}$ & $\frac{1 \mathrm{bc}}{1 \mathrm{~cd}}$ & $\frac{1302}{1303}$ & $\begin{array}{r}144,843 \\
148,994 \\
\end{array}$ & $\begin{array}{r}135,382 \\
143,449 \\
\end{array}$ & \begin{tabular}{|l|l|l|}
129,847 \\
137.928 \\
\end{tabular} & & & & & 0 & & & & $\frac{0}{0.08001726}$ & & & \\
\hline & RHR & $2 a b$ & 1304 & 138.267 & $\begin{array}{l}132,045 \\
132,023\end{array}$ & & & & & & 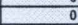 & & & & 0.080 & & & $\frac{184}{168}$ \\
\hline & RHR & $2 b c$ & 1305 & 141,843 & $\begin{array}{l}135,832 \\
1,20\end{array}$ & 129.847 & 0.0323749 & & & 70 & 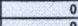 & & & & 0.0801726 & & & \\
\hline & RHR & $2 \mathrm{~cd}$ & 1306 & 148,994 & 143.449 & 137,928 & 30.0323749 & & & & & & & & & & & \\
\hline & & & & & & & & & & & & & & & & & & \\
\hline & CDT & $1 b c$ & 2001 & 112167 & $99,38=$ & 91,676 & 5 & $432.37 \mathrm{~s}$ & 383.101 & 353,391 & 19.926171 & 85,9 & 76.14 & 70.2 & 240.545366 & $1,037.3$ & & \\
\hline $\begin{array}{l}\text { Big ofox } \\
\text { Strip Mall }\end{array}$ & $\frac{\operatorname{CBB}}{\operatorname{CSM}}$ & $\frac{1 \mathrm{bc}}{1 \mathrm{bc}}$ & $\frac{2101}{2201}$ & $\frac{425,107}{311,723}$ & $\frac{379.013}{293409}$ & $\begin{array}{l}388.913 \\
285989\end{array}$ & 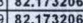 & 3555.56 & 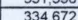 & 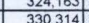 & $\begin{array}{l}79.96717 \\
19.967171\end{array}$ & $\frac{86.22}{8622}$ & $\frac{80.40}{81.15}$ & & & 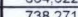 & & \\
\hline & & & & & & & & & & & & & & & & & & \\
\hline \multirow[t]{2}{*}{ Educational//nstitutional } & \begin{tabular}{|l|l|l|} 
EIS \\
EIS
\end{tabular} & $\frac{1 \mathrm{ab}}{1 \mathrm{bc}}$ & $\frac{3001}{3002}$ & & 0 & 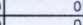 & & 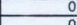 & & 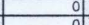 & & & & & 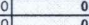 & & & \\
\hline & EIS & $\frac{1 c d}{1 c d}$ & 3003 & & & & & & & & & & & & & & & \\
\hline \multirow{3}{*}{$\begin{array}{l}\text { Open Space } \\
\text { Park lands, hydro, golficemetary }\end{array}$} & & & & & & & & & & & & & & & & & & \\
\hline & $O P L$ & Oab & 4001 & 108,595 & 102.588 & 96,637 & 7539.04143 & 259.09 & 244,759 & 230.561 & 397.2920 & 190,955 & 180,39 & 169.93 & 626. & 300 & 284 & 267.8 \\
\hline & OPL & ocd & 4003 & 169,417 & 154.376 & 159.379 & $\begin{array}{l}539.04143 \\
9\end{array}$ & 404,203 & 392,175 & $\mid \begin{array}{l}26,1325 \\
80,254 \\
\end{array}$ & 397.29203 39203 & $\frac{21.3087}{297.912}$ & 289.046 & \begin{tabular}{|l|l|}
192,156 \\
280.266 \\
\end{tabular} & $\begin{array}{l}80.223 \\
0 \\
0\end{array}$ & $\frac{335.81}{469,57}$ & \begin{tabular}{|l|l|}
319,180 \\
455,603
\end{tabular} & \begin{tabular}{|l|l|}
3035.83 \\
441.754 \\
\end{tabular} \\
\hline \multirow{2}{*}{ Valley lands, golficemetary } & OVIL & Oab & 4101 & & & 0 & o 142.26863 & 21,901 & 20,361 & 18,846 & 0.308664 & 48 & & & 10.0129884 & & & \\
\hline & 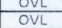 & \begin{tabular}{|l|l|}
$0 b c$ \\
$0 c d$ \\
\end{tabular} & $\frac{4102}{4103}$ & & & & $\begin{array}{l}0.142 .26663 \\
02.26863\end{array}$ & $-\frac{3.342}{63.259}$ & $\frac{28.85}{6833}$ & \begin{tabular}{|l|}
27.3232 \\
60427 \\
\end{tabular} & \begin{tabular}{|l|l|}
0.308664 \\
0.308664 \\
\end{tabular} & 136 & & & $\begin{array}{l}90.0129884 \\
110.012984\end{array}$ & & & \\
\hline \multirow{3}{*}{ Transportation } & & & & & & & & & & & & & & & & & & \\
\hline & $\frac{T H C}{T H C}$ & $\frac{0 a b}{0 b c}$ & 年5001 & & & & 0048295 & & & & 969250 & & 988 & & & & & \\
\hline & THC & ocd & 5003 & 167,181 & 167,181 & 167.181 & 5.3832502 & 9.25 & 9.252 & 9.25 & & & & & [0 11.119914 & 19,1 & 19,11 & 19,1 \\
\hline ndustrial & & & & & & & & & & & & & & & & & & \\
\hline \multirow{2}{*}{ Prestige } & $\frac{I P R}{I P R}$ & $\frac{1 \mathrm{ab}}{1 \mathrm{bc}}$ & $\frac{6001}{6002}$ & \begin{tabular}{|l|}
3857,799 \\
387,607 \\
\end{tabular} & $\begin{array}{l}366.300 \\
369,219 \\
\end{array}$ & 346.8621 & $\begin{array}{l}2184.95399 \\
1184.99539 \\
118\end{array}$ & $\frac{6525.801}{65,962}$ & \begin{tabular}{|l|l|}
6199.94 \\
62444 \\
\end{tabular} & \begin{tabular}{|l|}
587,007 \\
59725 \\
\end{tabular} & 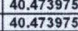 & \begin{tabular}{|l}
142.822 \\
143514 \\
\end{tabular} & \begin{tabular}{|l|l|}
135,62 \\
136,70 \\
\end{tabular} & \begin{tabular}{|l|}
128.42 \\
129.89 \\
\end{tabular} & $\begin{array}{l}8.868 .997767 \\
768.997667\end{array}$ & \begin{tabular}{|l|}
2434.475 \\
24454 \\
\end{tabular} & \begin{tabular}{l|l}
5 & 233,205 \\
4 & 233,048 \\
\end{tabular} & $\frac{218,936}{221,441}$ \\
\hline & $\frac{P R}{P B B}$ & $\frac{1 \mathrm{~cd}}{1 \mathrm{bc}}$ & \begin{tabular}{|l|l|}
60003 \\
6101 \\
\end{tabular} & $\begin{aligned} 3931.343 \\
2.257726 \\
\end{aligned}$ & \begin{tabular}{|l|l}
3750.075 \\
2.250 .990 \\
\end{tabular} & \begin{tabular}{|l|l}
3528,770 \\
2,24433 \\
\end{tabular} & 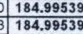 & $\frac{662.285}{705.52}$ & \begin{tabular}{|l|l|}
634.722 \\
703,768 \\
\end{tabular} & \begin{tabular}{|l|}
6071,60 \\
701,603 \\
\end{tabular} & 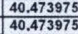 & \begin{tabular}{|l|}
144.897 \\
15407 \\
\end{tabular} & \begin{tabular}{|l|l|}
138.867 \\
153.53 \\
\end{tabular} & $\begin{array}{ll}132.83 \\
3\end{array}$ & $\begin{array}{l}7868.997667 \\
9988.09667\end{array}$ & 247,012 & \begin{tabular}{l|l} 
& 236,73 \\
\end{tabular} & $\frac{226.452}{334.11}$ \\
\hline \multirow{2}{*}{\multicolumn{4}{|c|}{ Jan, Nov, Dec Runoff Months }} & \multirow{2}{*}{\multicolumn{3}{|c|}{\begin{tabular}{|l|l|l|}
$2,819,832$ & $2,644,018$ & $2,482,104$ \\
\end{tabular}}} & & \multirow{2}{*}{\multicolumn{3}{|c|}{\begin{tabular}{|l|l|l|l|}
$1,812,7905,613$ & $1,615,972$ \\
\end{tabular}}} & & \multicolumn{3}{|c|}{\begin{tabular}{|l|l|l|}
520,864 & 497,239 & 477,652 \\
\end{tabular}} & & \multirow{2}{*}{\multicolumn{3}{|c|}{\begin{tabular}{|l|l|l|}
$1,518,358$ & $1,423,462$ & $1,365,733$ \\
\end{tabular}}} \\
\hline & & & & \multirow{2}{*}{\multicolumn{4}{|c|}{\begin{tabular}{|l|l|l|}
$12,546,306$ & $11,817,366$ & $11,144,501$ \\
\end{tabular}}} & & & & & & & & & & & \\
\hline \multicolumn{4}{|l|}{ TOTAL RUNOFF } & & & & & \multicolumn{3}{|c|}{\begin{tabular}{|l|l|l|}
$7,980,579$ & $7,522,965$ & $7,135,960$ \\
\end{tabular}} & & $2,086,362$ & $1,991,055$ & $1,911,96$ & & & & $546,07 \mathrm{~s}$ \\
\hline
\end{tabular}


Appendix F: Highland Creek Sub-Catchment Parameters

(Aquafor Beech Ltd., 2004) 
Table A.1

EXISTING LANDUSE SCENARIO

URBAN COMPONENT PARAMETERS

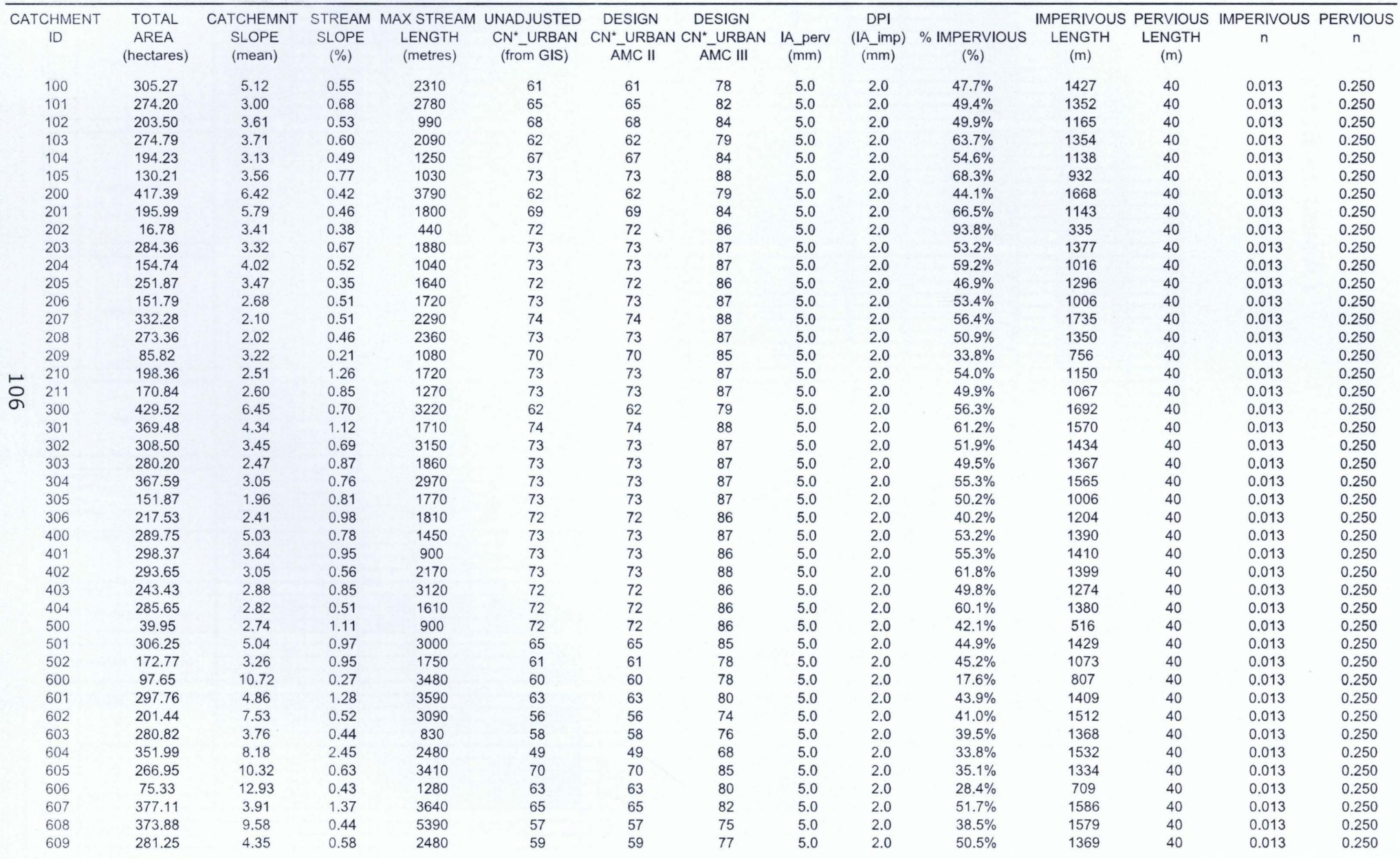


Table A.2

FUTURE LANDUSE SCENARIO

URBAN COMPONENT PARAMETERS

\begin{tabular}{|c|c|c|c|c|c|c|c|c|c|c|c|c|c|c|}
\hline $\begin{array}{l}\text { CATCHMENT } \\
\text { ID }\end{array}$ & $\begin{array}{l}\text { TOTAL } \\
\text { AREA } \\
\text { (hectares) }\end{array}$ & $\begin{array}{l}\text { CATCHEMNT } \\
\text { SLOPE } \\
\text { (mean) }\end{array}$ & $\begin{array}{l}\text { STREAM } \\
\text { SLOPE } \\
(\%)\end{array}$ & $\begin{array}{l}\text { MAX STREAM } \\
\text { LENGTH } \\
\text { (metres) }\end{array}$ & $\begin{array}{l}\text { UNADJUSTED } \\
\text { CN*_URBAN } \\
\text { (from GIS) }\end{array}$ & $\begin{array}{c}\text { DESIGN } \\
\text { CN }^{\star} \text { URBAN } \\
\text { AMC ॥ }\end{array}$ & $\begin{array}{l}\text { DESIGN } \\
\text { CN }^{*} \text { URBAN } \\
\text { AMC III }^{\text {A I I }}\end{array}$ & $\begin{array}{c}\text { IA_perv } \\
(\mathrm{mm})\end{array}$ & $\begin{array}{c}\text { DPI } \\
\left(\mathrm{IA} \_i \mathrm{mp}\right) \\
(\mathrm{mm})\end{array}$ & $\begin{array}{l}\text { \% IMPERVIOUS } \\
(\%)\end{array}$ & $\begin{array}{l}\text { IMPERIVOUS } \\
\text { LENGTH } \\
(\mathrm{m})\end{array}$ & $\begin{array}{l}\text { PERVIOUS } \\
\text { LENGTH } \\
(\mathrm{m})\end{array}$ & $\begin{array}{c}\text { IMPERIVOUS } \\
n\end{array}$ & $\begin{array}{c}\text { PERVIOUS } \\
n\end{array}$ \\
\hline 100 & 287.2 & 5.12 & 0.55 & 2310 & 61 & 61 & 78 & 5.0 & 2.0 & $46.0 \%$ & 1384 & 40 & 0.013 & 0.250 \\
\hline 100.1 & 18.18 & 5.12 & 0.55 & 2310 & 59 & 59 & 77 & 5.0 & 2.0 & $90.0 \%$ & 348 & 40 & 0.013 & 0.250 \\
\hline 101 & 185.26 & 3.00 & 0.68 & 2780 & 65 & 65 & 82 & 5.0 & 2.0 & $43.8 \%$ & 1111 & 40 & 0.013 & 0.250 \\
\hline 101.1 & 88.92 & 3.00 & 0.68 & 2780 & 70 & 70 & 85 & 5.0 & 2.0 & $90.0 \%$ & 770 & 40 & 0.013 & 0.250 \\
\hline 102 & 185.31 & 3.61 & 0.53 & 990 & 68 & 68 & 84 & 5.0 & 2.0 & $46.9 \%$ & 1111 & 40 & 0.013 & 0.250 \\
\hline 102.1 & 18.07 & 3.61 & 0.53 & 990 & 69 & 69 & 84 & 5.0 & 2.0 & $90.0 \%$ & 347 & 40 & 0.013 & 0.250 \\
\hline 103 & 115.05 & 3.71 & 0.60 & 2090 & 62 & 62 & 79 & 5.0 & 2.0 & $44.5 \%$ & 876 & 40 & 0.013 & 0.250 \\
\hline 103.1 & 159.8 & 3.71 & 0.60 & 2090 & 62 & 62 & 79 & 5.0 & 2.0 & $90.0 \%$ & 1032 & 40 & 0.013 & 0.250 \\
\hline 104 & 150.9 & 3.13 & 0.49 & 1250 & 68 & 68 & 84 & 5.0 & 2.0 & $47.9 \%$ & 1003 & 40 & 0.013 & 0.250 \\
\hline 104.1 & 43.37 & 3.13 & 0.49 & 1250 & 66 & 66 & 82 & 5.0 & 2.0 & $90.0 \%$ & 538 & 40 & 0.013 & 0.250 \\
\hline 105 & 20.5 & 3.56 & 0.77 & 1030 & 74 & 74 & 88 & 5.0 & 2.0 & $55.9 \%$ & 370 & 40 & 0.013 & 0.250 \\
\hline 105.1 & 109.71 & 3.56 & 0.77 & 1030 & 73 & 73 & 87 & 5.0 & 2.0 & $90.0 \%$ & 855 & 40 & 0.013 & 0.250 \\
\hline 200 & 409.83 & 6.42 & 0.42 & 3790 & 62 & 62 & 79 & 5.0 & 2.0 & $43.5 \%$ & 1653 & 40 & 0.013 & 0.250 \\
\hline 200.1 & 7.6 & 6.42 & 0.42 & 3790 & 59 & 59 & 77 & 5.0 & 2.0 & $90.0 \%$ & 225 & 40 & 0.013 & 0.250 \\
\hline 201 & 34.94 & 5.79 & 0.46 & 1800 & 68 & 68 & 84 & 5.0 & 2.0 & $59.9 \%$ & 483 & 40 & 0.013 & 0.250 \\
\hline 201.1 & 161.1 & 5.79 & 0.46 & 1800 & 70 & 70 & 85 & 5.0 & 2.0 & $90.0 \%$ & 1036 & 40 & 0.013 & 0.250 \\
\hline $\begin{array}{l}-202 \\
1\end{array}$ & N/A & $\mathrm{N} / \mathrm{A}$ & N/A & N/A & N/A & N/A & $\mathrm{N} / \mathrm{A}$ & N/A & N/A & N/A & N/A & $\mathrm{N} / \mathrm{A}$ & $\mathrm{N} / \mathrm{A}$ & N/A \\
\hline ○ 202.1 & 16.78 & 3.41 & 0.38 & 440 & 72 & 72 & 86 & 5.0 & 2.0 & $90.0 \%$ & 334 & 40 & 0.013 & 0.250 \\
\hline$\checkmark 203$ & 244.09 & 3.32 & 0.67 & 1880 & 73 & 73 & 87 & 5.0 & 2.0 & $51.9 \%$ & 1276 & 40 & 0.013 & 0.250 \\
\hline 203.1 & 40.2 & 3.32 & 0.67 & 1880 & 73 & 73 & 87 & 5.0 & 2.0 & $90.0 \%$ & 518 & 40 & 0.013 & 0.250 \\
\hline 204 & 80.55 & 4.02 & 0.52 & 1040 & 73 & 73 & 87 & 5.0 & 2.0 & $46.5 \%$ & 733 & 40 & 0.013 & 0.250 \\
\hline 204.1 & 74.4 & 4.02 & 0.52 & 1040 & 73 & 73 & 87 & 5.0 & 2.0 & $90.0 \%$ & 704 & 40 & 0.013 & 0.250 \\
\hline 205 & 229.05 & 3.47 & 0.35 & 1640 & 72 & 72 & 86 & 5.0 & 2.0 & $42.8 \%$ & 1236 & 40 & 0.013 & 0.250 \\
\hline 205.1 & 22.9 & 3.47 & 0.35 & 1640 & 74 & 74 & 88 & 5.0 & 2.0 & $90.0 \%$ & 391 & 40 & 0.013 & 0.250 \\
\hline 206 & 143.78 & 2.68 & 0.51 & 1720 & 73 & 73 & 87 & 5.0 & 2.0 & $51.8 \%$ & 979 & 40 & 0.013 & 0.250 \\
\hline 206.1 & 8 & 2.68 & 0.51 & 1720 & 74 & 74 & 88 & 5.0 & 2.0 & $90.0 \%$ & 231 & 40 & 0.013 & 0.250 \\
\hline 207 & 321.11 & 2.10 & 0.51 & 2290 & 74 & 74 & 88 & 5.0 & 2.0 & $55.3 \%$ & 1463 & 40 & 0.013 & 0.250 \\
\hline 207.1 & 11 & 2.10 & 0.51 & 2290 & 74 & 74 & 88 & 5.0 & 2.0 & $90.0 \%$ & 271 & 40 & 0.013 & 0.250 \\
\hline 208 & 268.6 & 2.02 & 0.46 & 2360 & 73 & 73 & 87 & 5.0 & 2.0 & $50.3 \%$ & 1338 & 40 & 0.013 & 0.250 \\
\hline 208.1 & 4.7 & 2.02 & 0.46 & 2360 & 74 & 74 & 88 & 5.0 & 2.0 & $90.0 \%$ & 177 & 40 & 0.013 & 0.250 \\
\hline 209 & 84.81 & 3.22 & 0.21 & 1080 & 70 & 70 & 85 & 5.0 & 2.0 & $33.4 \%$ & 752 & 40 & 0.013 & 0.250 \\
\hline 209.1 & 1 & 3.22 & 0.21 & 1080 & 74 & 74 & 88 & 5.0 & 2.0 & $90.0 \%$ & 82 & 40 & 0.013 & 0.250 \\
\hline 210 & 128.92 & 2.51 & 1.26 & 1720 & 73 & 73 & 87 & 5.0 & 2.0 & $47.8 \%$ & 927 & 40 & 0.013 & 0.250 \\
\hline 210.1 & 69.5 & 2.51 & 1.26 & 1720 & 73 & 73 & 87 & 5.0 & 2.0 & $90.0 \%$ & 681 & 40 & 0.013 & 0.250 \\
\hline 211 & 170.81 & 2.60 & 0.85 & 1270 & 73 & 73 & 87 & 5.0 & 2.0 & $49.9 \%$ & 1067 & 40 & 0.013 & 0.250 \\
\hline 211.1 & N/A & $\mathrm{N} / \mathrm{A}$ & N/A & N/A & N/A & N/A & $\mathrm{N} / \mathrm{A}$ & $\mathrm{N} / \mathrm{A}$ & N/A & N/A & N/A & N/A & N/A & N/A \\
\hline 300 & 168.58 & 6.45 & 0.70 & 3220 & 62 & 62 & 79 & 5.0 & 2.0 & $41.5 \%$ & 1060 & 40 & 0.013 & 0.250 \\
\hline 300.1 & 261.06 & 6.45 & 0.70 & 3220 & 70 & 70 & 85 & 5.0 & 2.0 & $90.0 \%$ & 1319 & 40 & 0.013 & 0.250 \\
\hline 301 & 172.46 & 4.34 & 1.12 & 1710 & 74 & 74 & 88 & 5.0 & 2.0 & $50.6 \%$ & 1072 & 40 & 0.013 & 0.250 \\
\hline 301.1 & 197 & 4.34 & 1.12 & 1710 & 75 & 75 & 88 & 5.0 & 2.0 & $90.0 \%$ & 1146 & 40 & 0.013 & 0.250 \\
\hline 302 & 247.48 & 3.45 & 0.69 & 3150 & 73 & 73 & 87 & 5.0 & 2.0 & $46.6 \%$ & 1284 & 40 & 0.013 & 0.250 \\
\hline 302.1 & 61 & 3.45 & 0.69 & 3150 & 73 & 73 & 87 & 5.0 & 2.0 & $90.0 \%$ & 638 & 40 & 0.013 & 0.250 \\
\hline 303 & 132.15 & 2.47 & 0.87 & 1860 & 73 & 73 & 87 & 5.0 & 2.0 & $52.6 \%$ & 939 & 40 & 0.013 & 0.250 \\
\hline 303.1 & 148.00 & 2.47 & 0.87 & 1860 & 72 & 72 & 86 & 5.0 & 2.0 & $90.0 \%$ & 993 & 40 & 0.013 & 0.250 \\
\hline
\end{tabular}


Table A.2 (Continued ...)

FUTURE LANDUSE SCENARIO

URBAN COMPONENT PARAMETERS

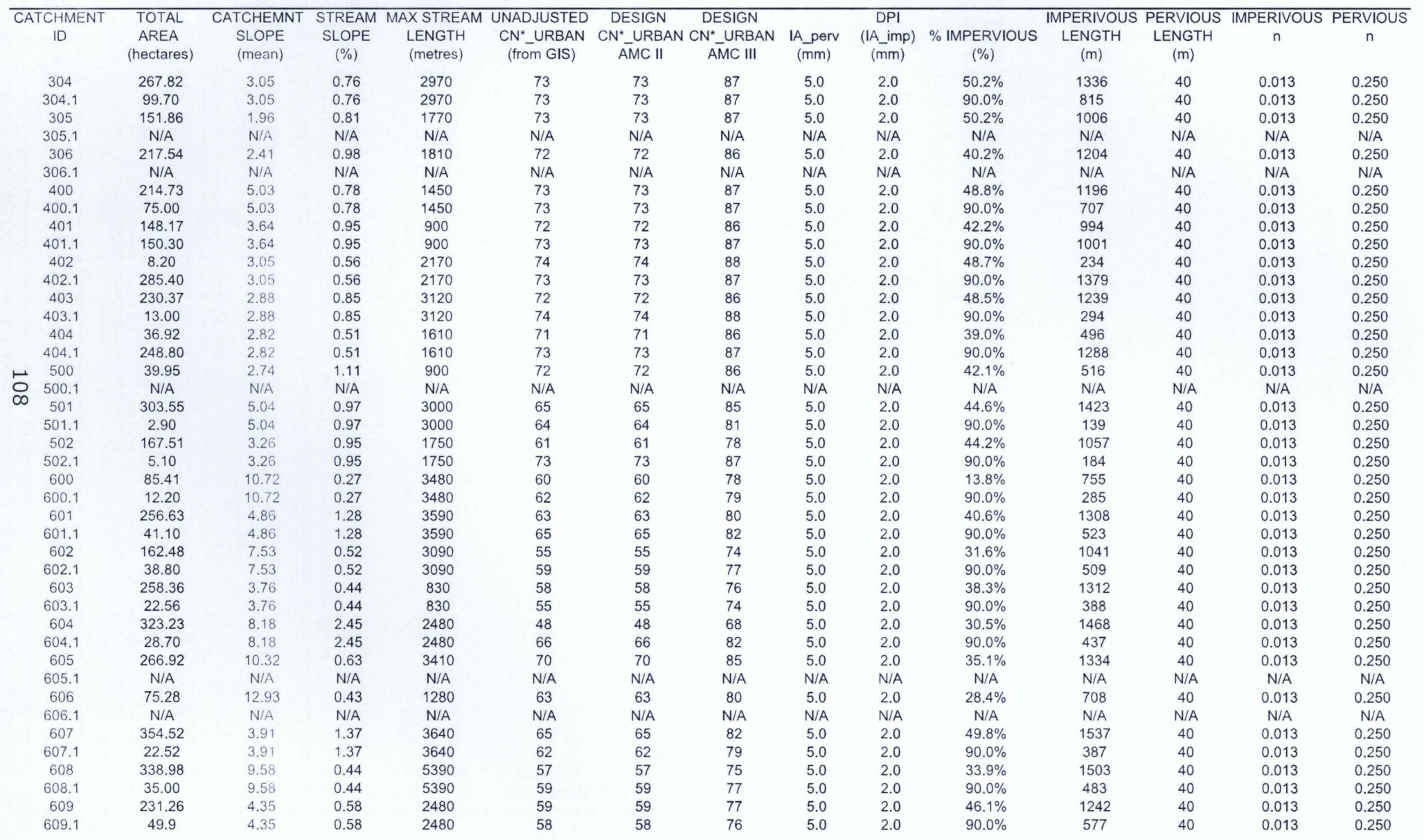

TOTALS $=10574.34$ 
Appendix G: Storm Hydrographs Used for Peak Flow Analysis

(Aquafor Beech LtD., 2004) 


\section{Storm Hydrograph Used for Peak Flow Analysis - Storm ID 1}

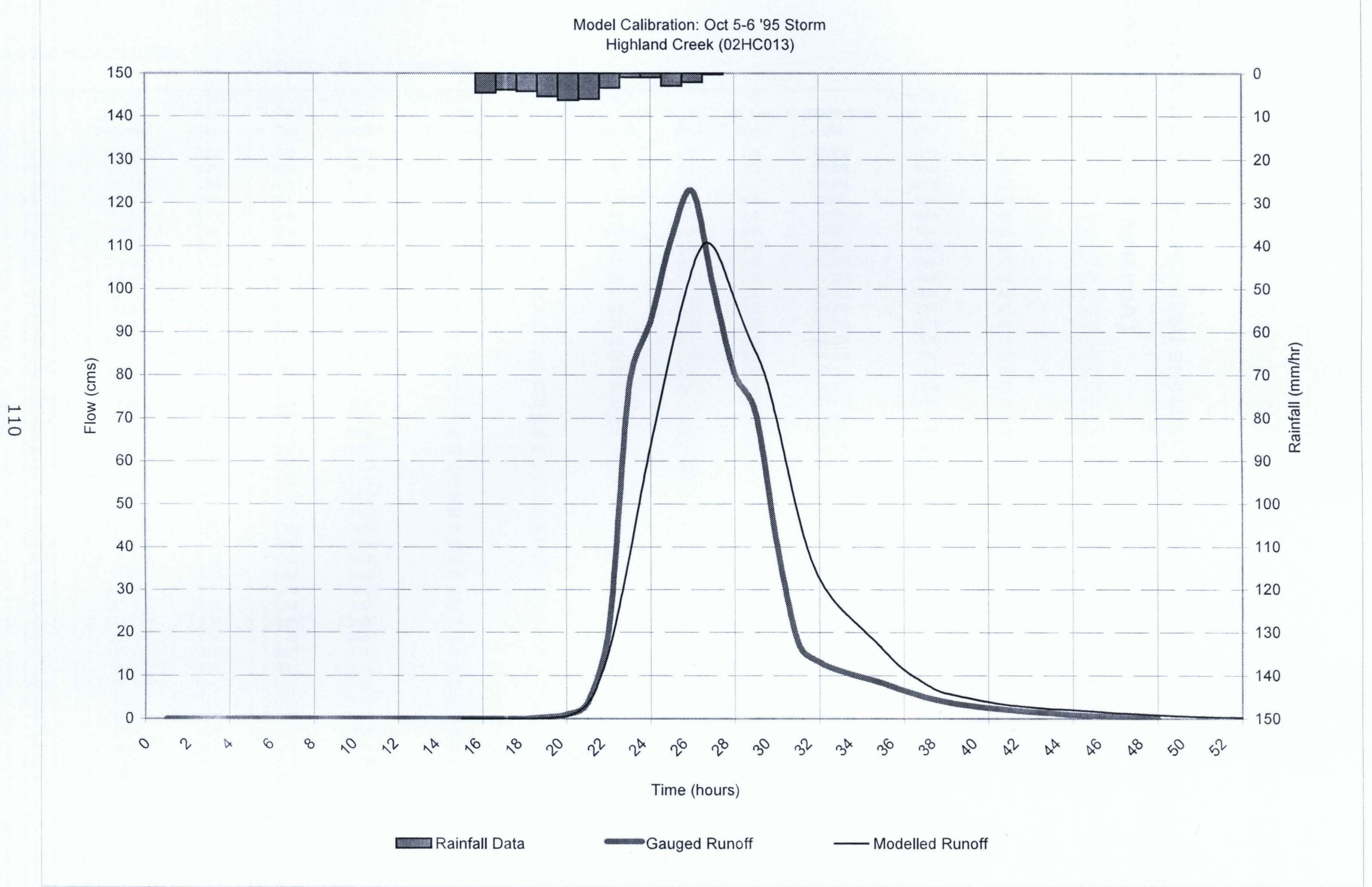


Storm Hydrograph Used for Peak Flow Analysis - Storm ID 2

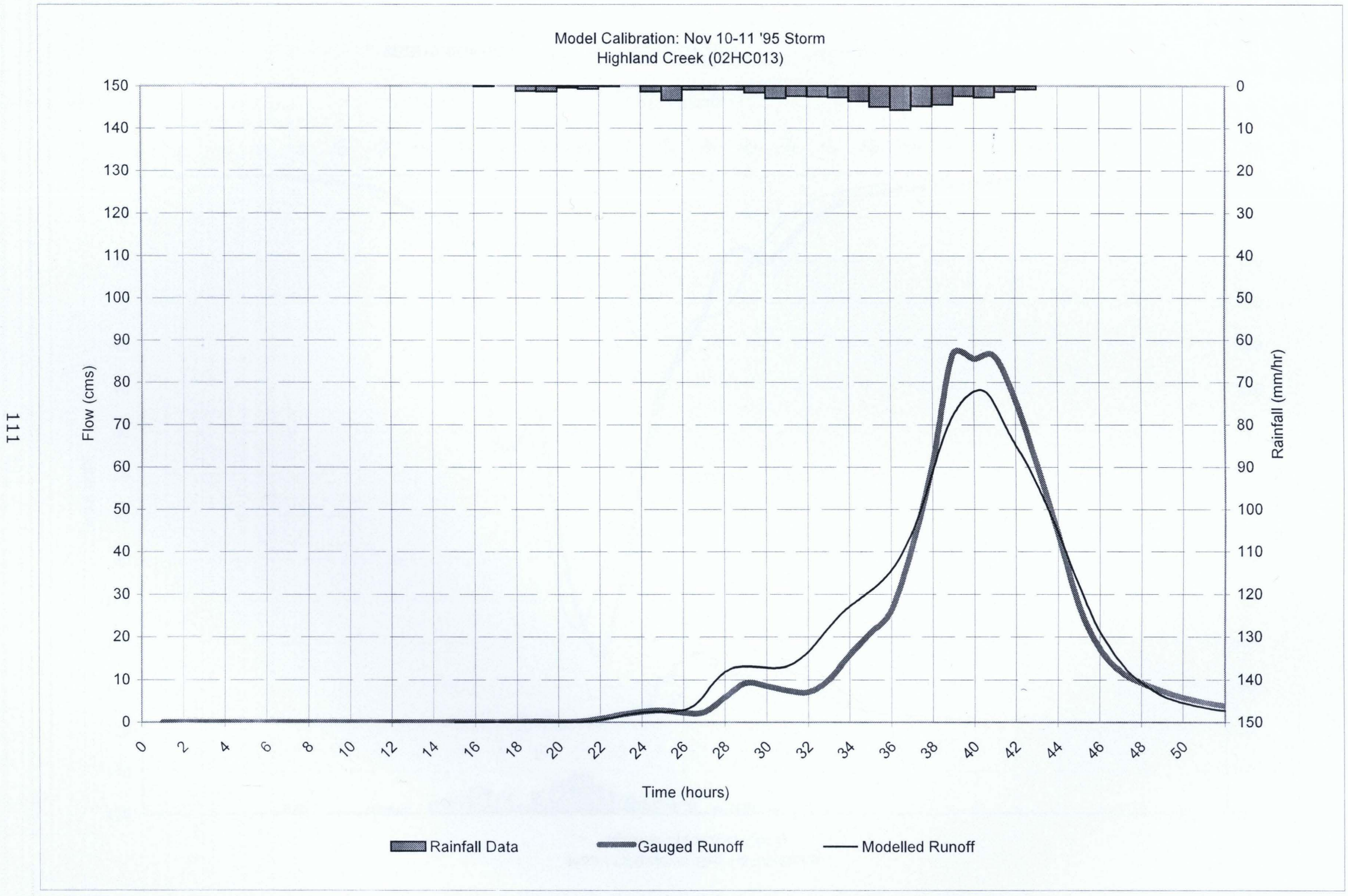

Appendix G 
Storm Hydrograph Used for Peak Flow Analysis - Storm ID 3

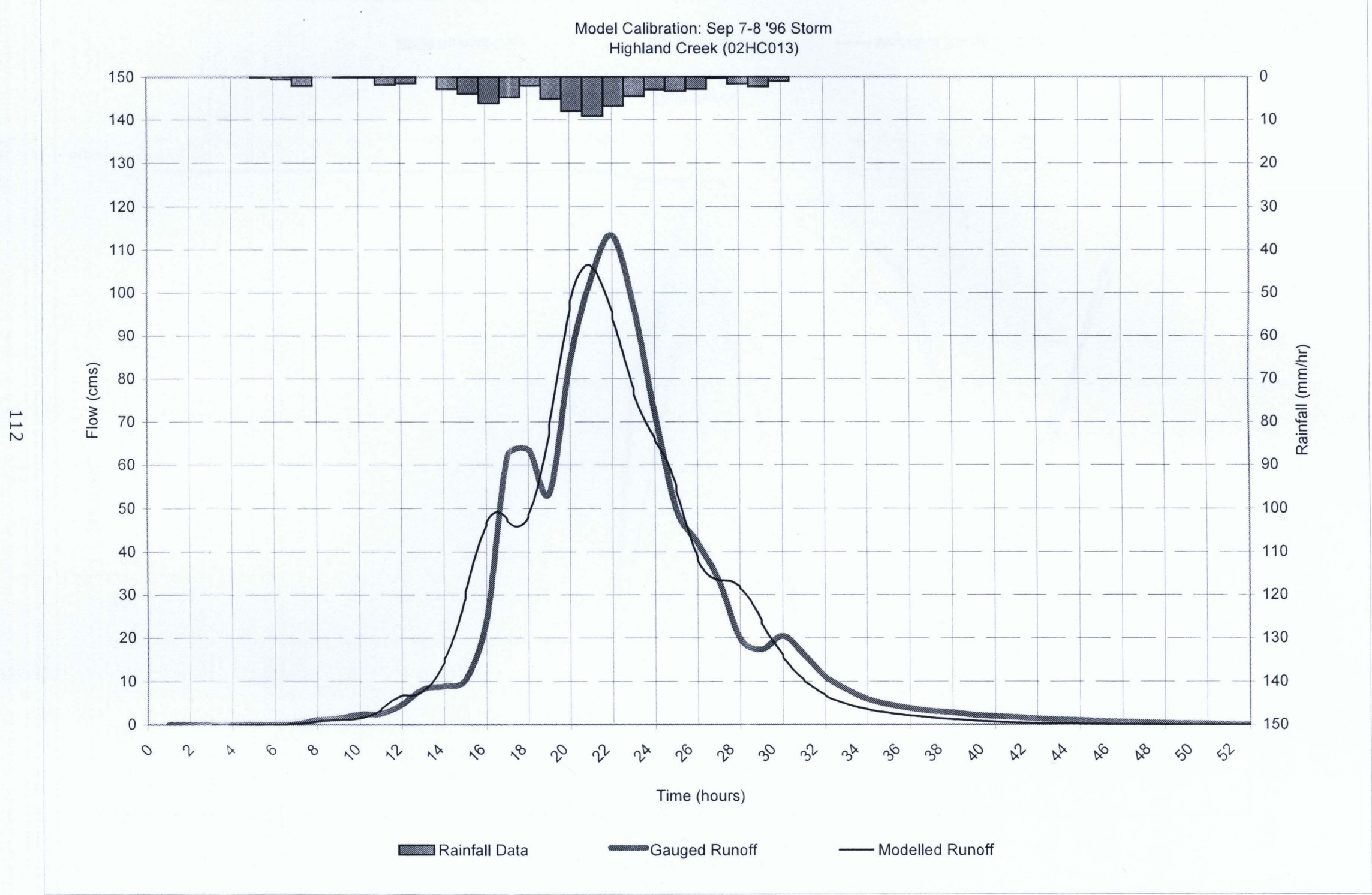

Appendix G 


\section{Storm Hydrograph Used for Peak Flow Analysis - Storm ID 4}

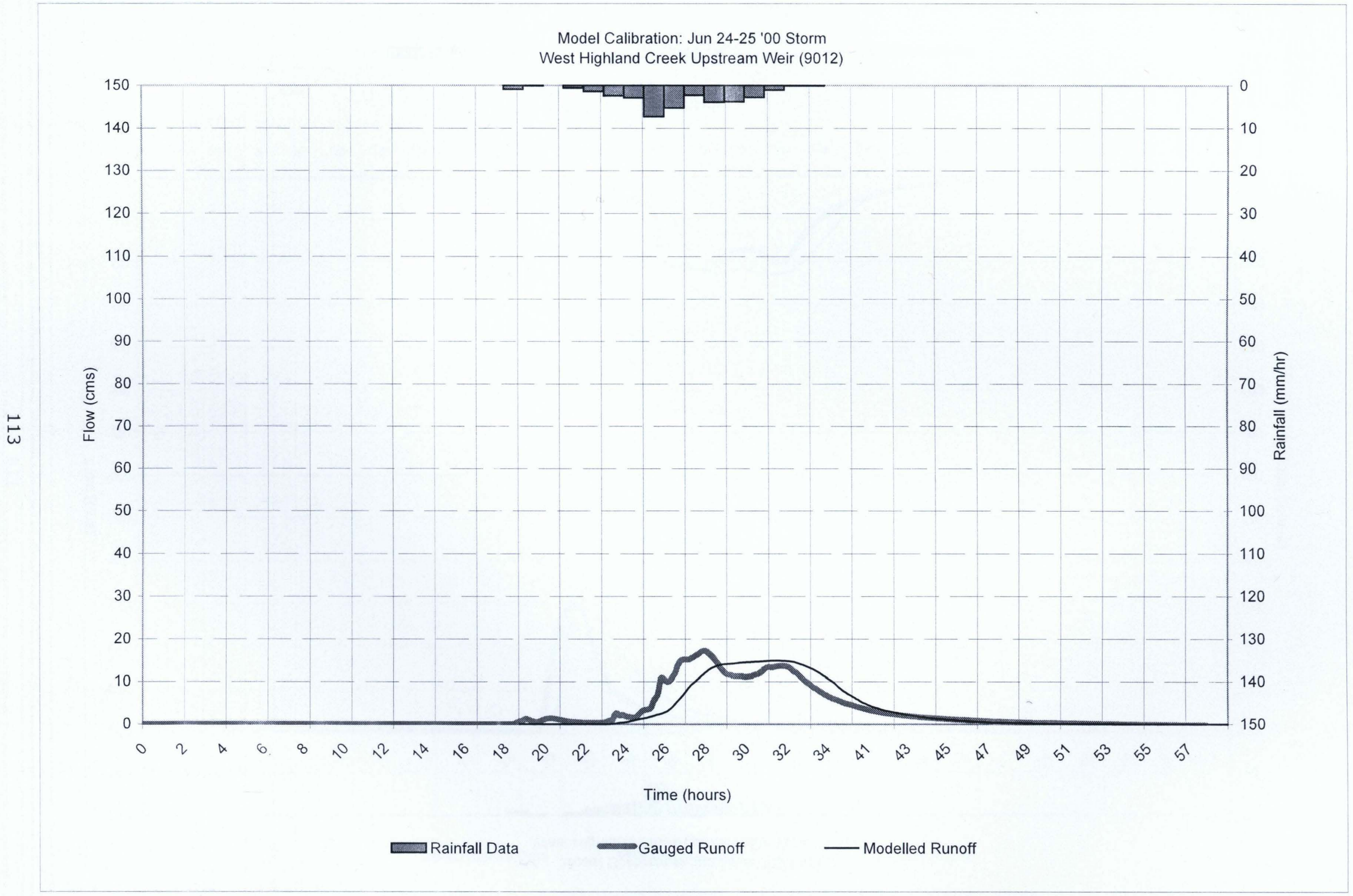


Storm Hydrograph Used for Peak Flow Analysis - Storm ID 5

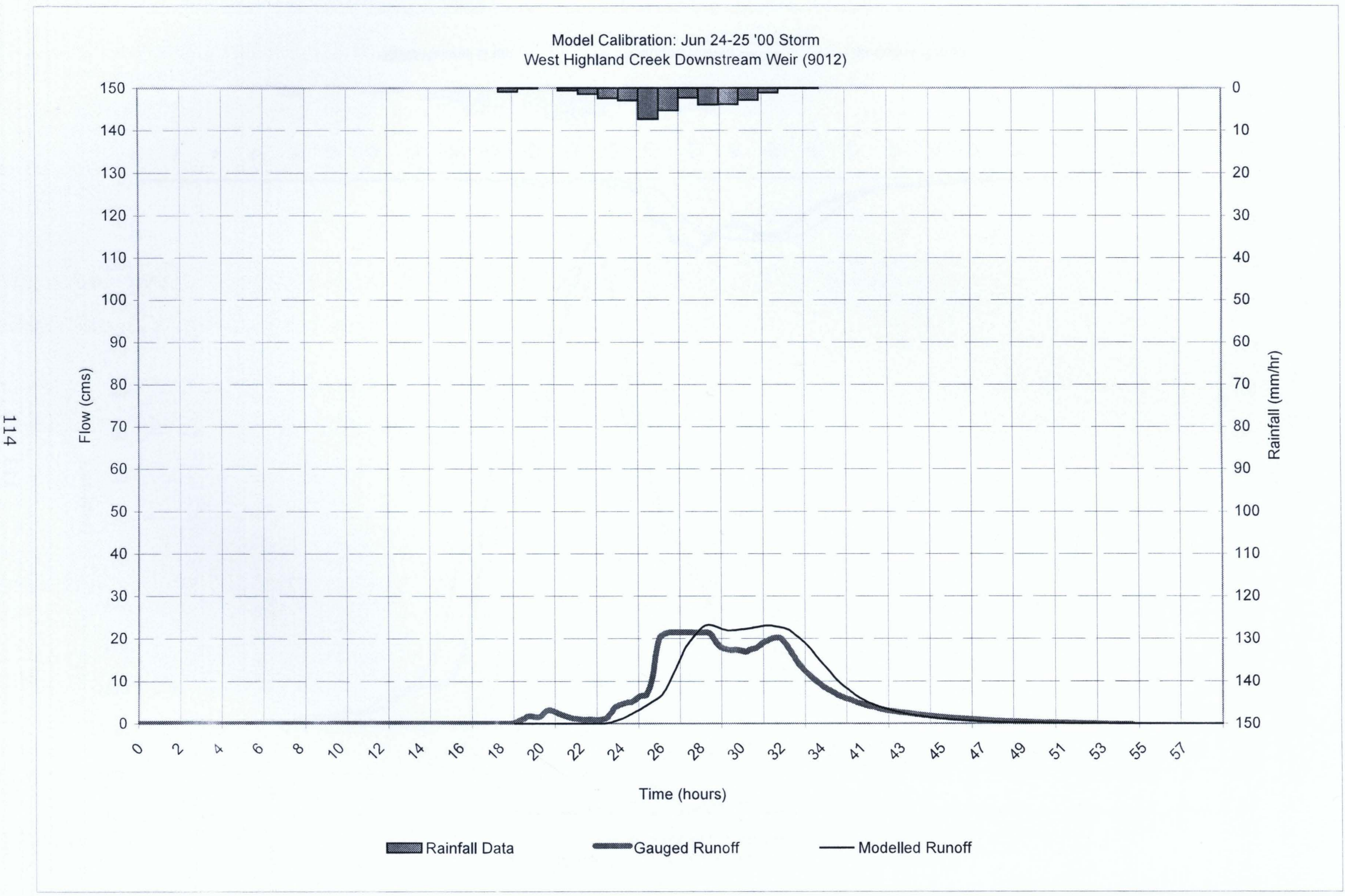

Appendix $G$ 


\section{Storm Hydrograph Used for Peak Flow Analysis - Storm ID 6}

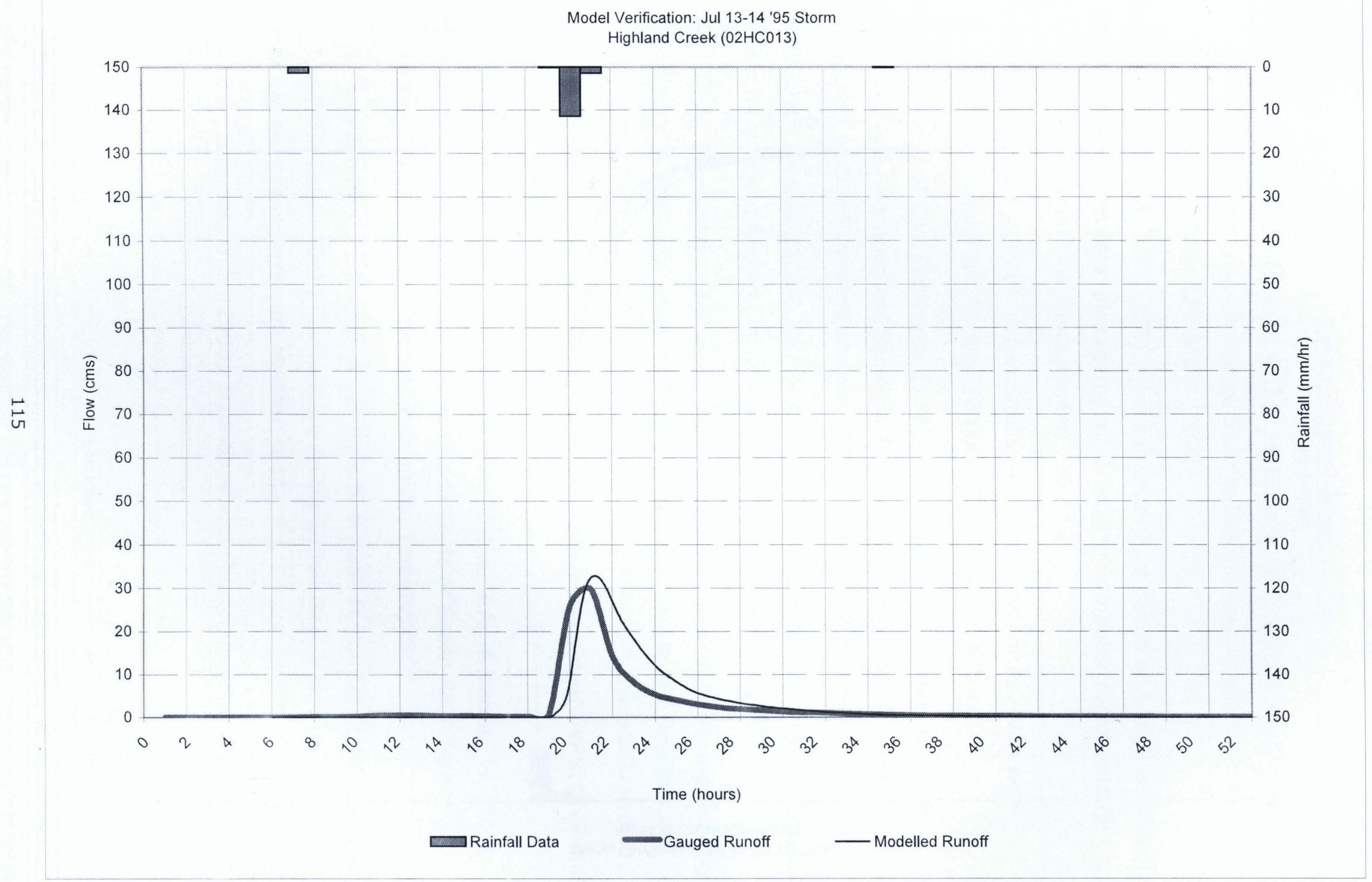

Appendix G 


\section{Storm Hydrograph Used for Peak Flow Analysis - Storm ID 7}

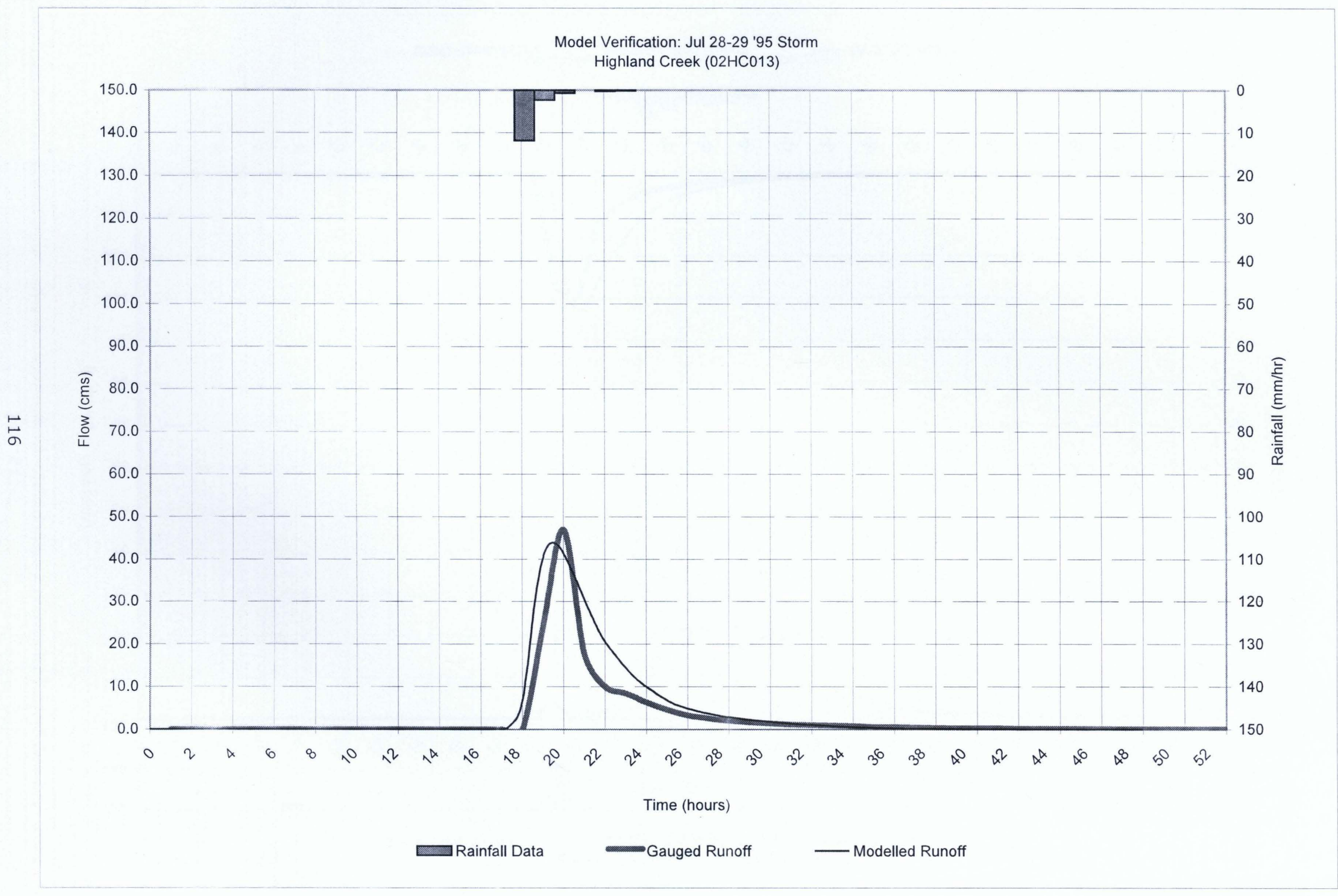




\section{LIST OF REFERENCES}

Adams, B.J., Fraser H.G., Howard, C.D.D., \& Hanafy, M.S. (1986). Meteorological Data Analysis for Urban Drainage System Design. Journal of Environmental Engineering, 112(5), 827-848.

Adams, B.J., \& Bontje, J.B. (1984). Microcomputer Application of Analytical Models for Urban Stormwater Management. Emerging Computer Techniques in Stormwater and Flood Management, 138-162.

Adams, B., \& Papa, F. (2000). Urban Stormwater Management Planning with Analytical Probabilistic Models. Toronto, ON: John Wily \& Sons.

American Society of Civil Engineers. (1992) Design and Construction of Urban Stormwater Management Systems. ASCE Manual, New York NY: American Society of Civil Engineers and the Water Environment Federation.

Aquafor Beech Limited. (2004). Highland Creek Hydrology Update. Report Prepared for Toronto and Region Conservation Authority, Downsview, ON.

Au, A. (2007). Simulation of the Stormwater Reduction and Energy Saving Benefits of Urban Greenroofs. M.A.Sc. Thesis, Environmental Applied Sciences and Management Program, Ryerson University, Toronto, ON: Ryerson University.

Banerjee, D. (2004). Technical Memorandum on HSP-F Green Roof URF's. Thornhill, ON: Marshall Macklin Monaghan.

Banting, D., Doshi, H., Li, J., Missios, P., Au, A., Currie, B.A., \& Verrati, M. (2005). Report on the Environmental Benefits and Costs of Green Roof Technology for the City of Toronto. Ryerson University, Toronto, ON.

Bass, B., Krayenhoff, E.F., Martilli, A., Stull, R.B. \& Auld, H. (2002). Modelling the Impact of Green Roof Infrastructure on the Urban Heat Island in Toronto. Green Roofs Infrastructure Monitor. 4(1).

Bedient, P.B., \& Huber, W.C. (2008). Hydrology and Floodplain Analysis. Don Mills ON: Addison-Wesley Publishing Company. 
Behera, P.K., Adams, B.J., \& Li, J.Y. (2006). Runoff Quality Analysis of Urban Catchments with Analytical Probabilistic Models. Journal of Water Resources Planning and Management. 132(1), 4-14.

Belanger, S. (1992). An Atlas of Statistics of Rainfall Characteristics for Ontario.

B.A.Sc. Thesis, Department of Civil Engineering, University of Toronto, Toronto, ON: University of Toronto.

Bengtsson, L., Grahn, L., \& Olsson, J. (2005). Hydrological Function of a Thin Extensive Green Roof in Souther Sweden. North Hydrology. 36(3), 259-268.

Cackowski, J.M., \& Nasar, J.L. (2003). The Restorative Effects of Roadside Vegetation - Implications for Automobile Driver Anger and Frustration. Environment and Behavior, 35(6), 736-751.

Casey Trees \& LimnoTech. (2007). The Green Build-out Model: Quantifying the Stormwater Management Benefits of Trees and Green Roofs in Washington, $D C$. Report prepared for US EPA, Washington, DC.

Chen, J., \& Adams, B.J. (2004). Urban Storm Water Control Evaluation with Analytical Probabilistic Models. Journal of Water Resources Planning and Management, 131(5), 362-374.

City of Toronto. (2003). Toronto Wet Weather Master Flow Plan. (2003). Toronto, ON: City of Toronto. Retrieved September 12, 2008, from http://www.toronto.ca/water/protecting_quality/wwfmmp/index.htm

Clark, C., Adriaens, P., \& Talbot, B. (2008). Green Roof Valuation: A Probabilistic Economic Analysis of Environment Benefits. Environmental Science \& Technology, 42(6), 2155-2161.

Currie, B.A. (2005). Estimates of Air Pollution Mitigation with Green Roofs Using the UFORE Model. M.A.Sc. Thesis, Environmental Applied Sciences and Management Program, Ryerson University, Toronto, ON: University of Ryerson.

Dunnett, N., \& Kingsbury, N. (2008). Planting Green Roofs and Living Walls. Portland, OR: Timber Press. 
Earth Pledge Foundation. (2005). Green roofs: ecological design and construction. Atglen, PA, Schiffer Publishers.

Fang, X., Thompson, D.B., Cleveland, T.G., \& Pradhan, P. (2007). Variations of Time of Concentration Estimates Using NRCS Velocity Method. Journal of Irrigation and Drainage Engineering, 133(4), 314-322.

Gedge, D., \& Kadas, G. (2005). Green Roofs and Biodiversity. Biologist, 52(3), 161-169.

Guo, Y. (1998). Development of Analytical Probabilistic Urban Stormwater Models. Ph. D. Thesis, Civil Engineering Program, University of Toronto, Toronto, ON: University of Toronto.

Howard, C.D.D. (1976). Theory of Storage and Treatment Plant Overflows. Journal of Environmental Engineering, 102(EE4), 709-722.

Hutchinson, D., Abrams, P. Retzlaff, R., \& Liptan, Tom. (2003). Stormwater Monitoring Two Ecoroofs in Portland, Oregon, USA. Chicago, IL: Greening Rooftops for Sustainable Communities.

Johnston, J., \& Newton, J. (1993). Building Green, A Guide for Using Plants on Roofs, Walls and Pavements. London UK, The London Ecology Unit.

Kauffman, G.M. (1987). A Comparison for Analytical and Simulation Models for Drainage System Design: SUDS versus STORM. M.A.Sc. Thesis, Civil Engineering Progran, University of Toronto, Toronto, ON: University of Toronto.

Kohler, M., Schmidth, M., Grimme, F.W., Laar, M., de Assuncao Paiva, V.L., \& Tavares, S. (2002). Green-roofs in Temperate Climates and in the Hothumid Tropics - Far Beyond the Aesthetics. Environmental Management and Health, 13(4), 382-391.

Li, J. (1991). Comprehensive Urban Runoff Control Planning. Ph.D. Thesis, Civil Engineering Program, University of Toronto, Toronto, ON: University of Toronto. 
Li, J. (2006). Evaluation of Stormwater Peformance of Greenroofs in Toronto.

Report prepared for the government of Canada's Great Lakes Sustainability Fund, Burling, ON.

$\mathrm{Li}, \mathrm{J}$. (2007). Modelling the Stormwater Benefits of Green Roofs in the City of Toronto. Unpublished manuscript.

Li, J., \& Adams, B. (1990). Optimization of Urban Runoff Quantity/Quality Management. Environmetrics, 1(3/4), 321-336.

Li, J., \& Adams, B. (1993). New Techniques for Modelling the Management of Stormwater Quality Impact. Boca Raton, FL: Lewis Publishers.

Li, J., \& Adams, B. (1994). Statistical Water Quality Modelling for Urban Runoff Control Planning. Water Science and Technology, 29(1-2), 181-190.

Li, J., \& Adams, B. (2000). Probabilistic Models for Analysis of Urban Runoff Control Systems. Journal of Environmental Engineering, 126(3), 217-224.

Liu, K. (2004). Sustainable Building Envelope - Garden Roof System Performance. Ottawa, ON: National Research Council.

Liu, K., \& Baskaran, B. (2003). Thermal Performance of Green Roofs Through Field Evaluation. Proc. Greening Rooftops for Sustainable Communities, Chicago, May 29-30.

Liesecke, H. (1998). Das Retentionsvermogen von Dachbegrunungen, Stadt Und Grun, 47, 46-53.

Marsh, W., \& Grossa, J. (1996). Environmental Geography. Toronto ON: John Wiley \& Sons Inc.

Maunder, D. (2004). Technical Memorandum on HSP-F, Modelling of Green Roofs Markham Branch of Highland Creek. Brampton, ON: Aquafor Beech Limited.

Moran, A., Hunt B., \& Jennings, G. (2003). A North Carolina Field Study to Evaluate Greenroof Runoff Quantity, Runoff Quality, and Plant Growth. Las Vegas NV: ASAE Annual International Meeting. 
Moran, A., Hunt B., \& Jennings, G. (2004). Greenroof Research of Stormwater Runoff Quantity and Quality in North Carolina. NCSU Water Quality Group Newsletter, 114.

Natural Resources Conservation Service (NRCS). (1972). Travel Time, Time of Concentration and Lag. The National Engineering Handbook. Washington, DC: U.S. Dept. of Agriculture.

Niachou, A., Papakonstantinou, K., Santamouris, M., Tsangrassoulis, A., \& Mihalakakou, G. (2001). Analysis of the green roof thermal properties and investigation of its energy performance. Energy and Buildings, 33, 719-729.

Nicholaus, D., VanWoert, D., Bradley, R., Andresen, J., \& Clayton, L. (2005). Green Roof Stormwater Retention: Effects of Roof Surface, Slope, and Media Depth. Journal of Environmental Quality, 34(3), 1036-1044.

Papa, F. (1997). Analytical Probabilistic Models for Urban Stormwater Management Planning. M.A.Sc. Thesis, Civil Engineering Program, University of Toronto, Toronto, ON: University of Toronto.

Papa, F., \& Adams, B. (1997). Application of Derived Probability and Dynamic Programming Techniques to Planning Regional Stormwater Management Systems. Water Science Technology, 36(5) 227-234.

Perry, M.D. (2003). Green Roofs Offer Environmentally Friendly Alternative. Plant Engineering, 57(8), 54-56.

Rowe, D.B., Rugh, C.L., VanWoert, N., Monterusso, M.A., \& Russell, D.K. (2003). Green Roof Slope, Substrate Depth, and Vegetation Influence Runoff. Proceedings of $1^{\text {st }}$ North American Green Roof Conference: Greening Rooftops for Sustainable Communities, Chicago. May 29-30.

Saltelli, A., Tarantola, S., Campolongo, F., \& Ratto, M. (2004). Sensitivity Analysis in Practice. A Guide to Assessing Scientific Models. Toronto, ON: John Wiley \& Sons.

Sherman, R. (2005). Compost Plays Key Role in Green Roof Mixes. Biocycle, 46(3), 29-32. 
Smith, D. I. (1980). Probability of Storage Overflows for Stormwater Management. M.A.Sc. thesis, Civil Engineering Program, University of Toronto, Toronto, ON: University of Toronto.

Schwarz, R.B., \& Adams, B.J. (1981). Distributed Storage for Urban Runoff Control, Proceedings. Second International Conference on Urban Storm Drainage, Urbana, IL.

Toronto and Region Conservation Authority. (1999). State of the Watershed Report: Highland Creek Watershed. Downsview, ON: TRCA.

Toronto and Region Conservation Authority. (2006). Stormwater Performance of the York University's Greenroof. Burlington, ON: Canada's Great Lakes Sustainability

Wong, N.H., Tay, S., Wong, R., Ong, C., \& Sia, A. (2003). Life cycle cost analysis of rooftop gardens in Singapore. Building and Environment, 38, 499-509.

Viessman, W., Lewis, G., \& Knapp, J. (1996). Introduction to Hydrology. New York, NY: Harper \& Row. 


\section{LIST OF ACRONYMS}

BMP

BOD

CSM

CSO

GTA

HSP-F

IETD

NRCS

PAH

pdf

QQS

STORM

SUDS

TRCA

UFORE

UARF

URF

WWFMMP
Best Management Practice

Biological Oxygen Demand

Continuous Simulation Model

Combined Sewer Overflow

Greater Toronto Area

Hydrological Simulation Program - Fortran

Interevent Time Definition

Natural Resources Conservation Service

Poly Aromatic Hydrocarbons

Probability Distribution Function

Quantity-Quality Simulation

Storage, Treatment, Overflow, Runoff Model

Sustainable Urban Drainage Systems

Toronto and Region Conservation Authority

Urban Forest Effects

Unit-area Reduction Factors

Unit Response Function

Wet Weather Flow Management Master Plan 